Supporting Information

\title{
Linear Hydrocarbon Chain Growth from a Molecular Diruthenium Carbide Platform
}

Jun Ohata, Akira Teramoto, Hiroaki Fujita, Shin Takemoto, ${ }^{*}$ and Hiroyuki Matsuzaka* Department of Chemistry, Graduate School of Science, Osaka Prefecture University, Gakuencho 1-1, Naka-ku, Sakai, Osaka 599-8531, Japan

Email: takemoto@c.s.osakafu-u.ac.jp (S.T.); matuzaka@c.s.osakafu-u.ac.jp (H.M.)

\section{Table of Contents}

\section{Experimental Details}

$1-1$. General considerations................................................ S2

1-2. Synthesis of new compounds.......................................... 22

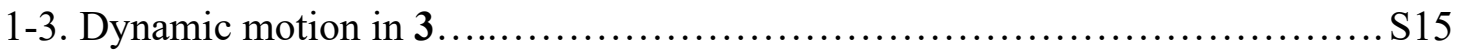

1-4. Liberation of hydrocarbons............................................ S17

1-5. Attempts to induce thermal isomerization of $\mathbf{3}$ to $7 \ldots \ldots \ldots \ldots \ldots \ldots \ldots . . \ldots \ldots$

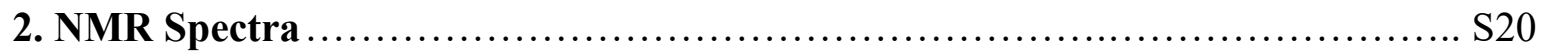

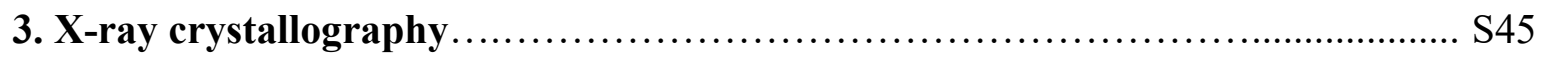

\section{Computational Details}

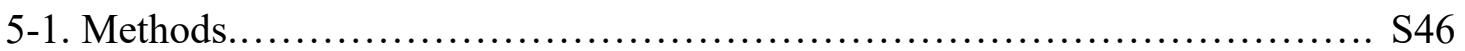

5-2. Optimized geometries and atomic coordinates....................... S46

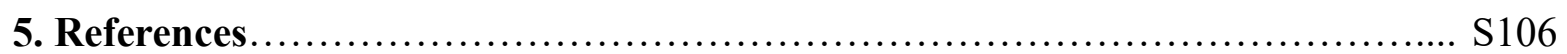




\section{Experimental Details}

\section{1-1. General considerations}

All operations were performed under inert atmosphere using standard Schlenk techniques or in a glove box, employing dry solvents and glassware unless otherwise noted. Complexes 2 and $[\mathrm{Cp} * \mathrm{Ru}(\mu-\mathrm{NHPh})]_{2}$ were prepared as described previously. ${ }^{1}$ The compound $\left[\mathrm{Ph}_{2} \mathrm{~S}^{13} \mathrm{CH}_{3}\right][\mathrm{OTf}]$ was prepared from ${ }^{13} \mathrm{CH}_{3} \mathrm{OTf}$ (Isotech) by adopting the procedure described for the synthesis of $\left[\mathrm{Ph}_{2} \mathrm{SCH}_{3}\right][\mathrm{OTf}] .^{2} \quad$ Cyclopropyldiphenylsulfonium tetrafluoroborate was prepared according to the literature procedure. ${ }^{3}$ Deuterated solvents were degassed by freezepump-thaw cycles and stored in J-Young flasks containing molecular sieves which were vacuum dried overnight at $300{ }^{\circ} \mathrm{C}$ prior to use. Other reagents and solvents were purchased from commercial venders and used as received. NMR spectra were obtained on JEOL ECP500 or Varian VNMR400 spectrometers. ${ }^{1} \mathrm{H}$ and ${ }^{13} \mathrm{C}$ NMR chemical shifts are reported relative to residual solvent peaks. Elemental analyses were performed on a Perkin Elmer 2400 Series II analyzer. GC analyses were performed on a Shimadzu GC-2025 chromatograph equipped with a flame ionization detector and a Rt-Q-BOND capillary column $(0.32 \mathrm{~mm}$ inner diameter, $10 \mu \mathrm{m}$ thickness, $30 \mathrm{~m}$ length).

\section{1-2. Synthesis of new compounds}

\section{$\left[\left(C p^{*} \mathrm{Ru}\right)_{2}(\mu-\mathrm{NPh})\left(\mu-\eta^{1}: \eta^{3}-\mathrm{H}_{2} \mathrm{CCCH}_{2}\right)\right](3)$}

(a) From 2 and $\mathrm{Ph}_{2} \mathrm{SCH}_{2}$.

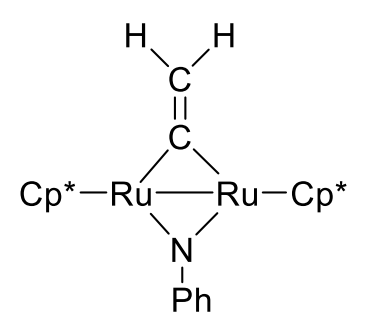

2

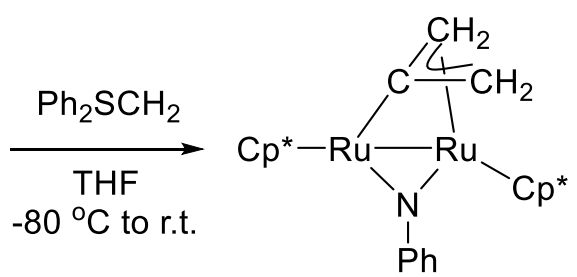

3

A stirred suspension of $\left[\mathrm{Ph}_{2} \mathrm{SCH}_{3}\right]\left[\mathrm{BF}_{4}\right](264 \mathrm{mg}, 0.916 \mathrm{mmol})$ in THF $(6 \mathrm{~mL})$ was treated with $\mathrm{NaN}\left(\mathrm{SiMe}_{3}\right)_{2}(1.09 \mathrm{M}$ in THF, $0.91 \mathrm{~mL}, 0.99 \mathrm{mmol})$ at $-80{ }^{\circ} \mathrm{C}$ and warmed gradually to $10{ }^{\circ} \mathrm{C}$ to generate $\mathrm{Ph}_{2} \mathrm{SCH}_{2}$. The resulting white yellow suspension was cooled to $-80{ }^{\circ} \mathrm{C}$ and transferred via canula to a Schlenk flask containing a solution of $2(210 \mathrm{mg}, 0.355 \mathrm{mmol})$ in THF $(7 \mathrm{~mL})$ that was also cooled to $-80{ }^{\circ} \mathrm{C}$. The resulting mixture was allowed to warm to 
room temperature, stirred for $12 \mathrm{~h}$, and evaporated to dryness under reduced pressure. The brown residue was extracted with toluene $(10 \mathrm{~mL})$, and the extract was concentrated to ca. 1.5 $\mathrm{mL}$. Recrystallization from a toluene-acetonitrile $(1.5 \mathrm{~mL} / 9 \mathrm{~mL})$ two-layer mixture afforded brown plates of $\mathbf{3}$, which were collected by filtration and dried in vacuo. Yield $105 \mathrm{mg}, 0.175$ mmol, 49\%. Anal. Calcd (\%) for $\mathrm{C}_{29} \mathrm{H}_{39} \mathrm{NRu}_{2}$ : C, 57.69; H, 6.51; N, 2.32. Found: C, 57.91; $\mathrm{H}, 6.71 ; \mathrm{N}, 2.17 .{ }^{1} \mathrm{H}$ NMR (400 MHz, $\left.\mathrm{C}_{6} \mathrm{D}_{6}\right): \delta 7.05$ (m, 3H, Ph), 6.95 (m, 2H, Ph), 4.65 (m, $\left.1 \mathrm{H}, H_{2} \mathrm{CCC}^{\prime} \mathrm{H}_{2}\right), 3.45$ (m, 1H, $\left.\mathrm{H}_{2} \mathrm{CCC}^{\prime} \mathrm{H}_{2}\right), 3.32\left(\mathrm{~m}, 1 \mathrm{H}, \mathrm{H}_{2} \mathrm{CCC}^{\prime} H_{2}\right), 2.96$ (m, $\left.1 \mathrm{H}, \mathrm{H}_{2} \mathrm{CCC}^{\prime} H_{2}\right)$, 1.77, 1.45 (s, 15H each, $\left.\mathrm{C}_{5} \mathrm{Me}_{5}\right) .{ }^{13} \mathrm{C}\left\{{ }^{1} \mathrm{H}\right\}$ NMR (101 MHz, $\left.\mathrm{C}_{6} \mathrm{D}_{6}\right): \delta 171.2\left(\mathrm{H}_{2} \mathrm{CCC}^{\prime} \mathrm{H}_{2}\right)$, 159.8, 128.2, 120.7, $116.8(\mathrm{Ph}), 94.9,92.3\left(C_{5} \mathrm{Me}_{5}\right), 75.2\left(\mathrm{H}_{2} \mathrm{CCC}^{\prime} \mathrm{H}_{2}\right), 65.0\left(\mathrm{H}_{2} C \mathrm{CC}^{\prime} \mathrm{H}_{2}\right), 11.9$, $10.7\left(\mathrm{C}_{5} M e_{5}\right)$. Attempted synthesis of 3 employing 1 equiv of $\mathrm{Ph}_{2} \mathrm{SCH}_{2}$ resulted in the formation of $\mathbf{3}$ with incomplete conversion of $\mathbf{2}$ probably due to competing partial decomposition of the thermally unstable $\mathrm{Ph}_{2} \mathrm{SCH}_{2}$.

(b) From $[\mathrm{Cp} * \mathrm{Ru}(\mu-\mathrm{NHPh})]_{2}$ and $\mathrm{H}_{2} \mathrm{C}=\mathrm{C}=\mathrm{CH}_{2}$.
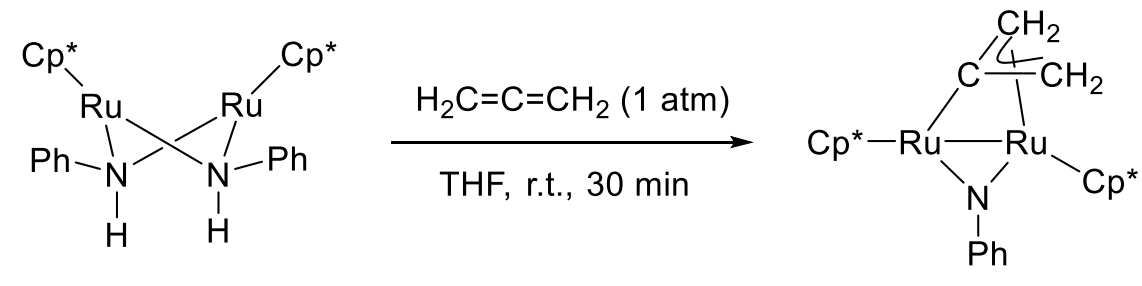

3

In a 30-mL Schlenk tube, $[\mathrm{Cp} * \mathrm{Ru}(\mu-\mathrm{NHPh})]_{2}(90 \mathrm{mg}, 0.137 \mathrm{mmol})$ was dissolved in THF (7 $\mathrm{mL}$ ). The tube was degassed with a vacuum pump and then filled with allene gas (1 atm). After the tube was sealed, the solution was stirred at room temperature for $30 \mathrm{~min}$. The solvent was removed in vacuo, and the residue was recrystallized from toluene-acetonitrile. The dark brown plates that deposited were collected by filtration and dried in vacuo. Yield $51 \mathrm{mg}, 0.084$ mmol, $61 \%$.

Formation of $\left[\left(C p^{*} \mathrm{Ru}\right)_{2}(\mu-\mathrm{NPh})\left(\mu-\eta^{1}: \eta^{3}-\mathrm{H}_{2} \mathrm{CC}^{13} \mathrm{CH}\right)\right]\left(3-{ }^{13} \mathrm{C}\right)$.

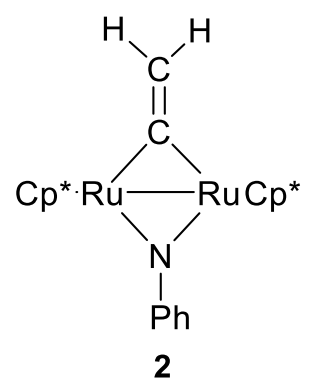

2

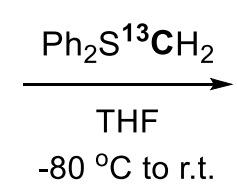

$-80^{\circ} \mathrm{C}$ to r.t.

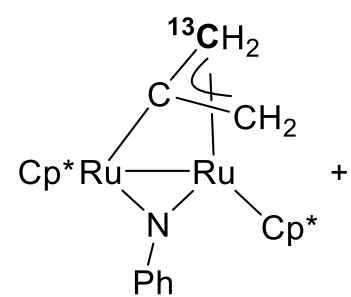

$3-{ }^{13} \mathrm{C}(1: 1$ mixture $)$

A stirred solution of $\left[\mathrm{Ph}_{2} \mathrm{~S}^{13} \mathrm{CH}_{3}\right][\mathrm{OTf}](198 \mathrm{mg}, 0.563 \mathrm{mmol})$ in THF $(6 \mathrm{~mL})$ was treated with $\mathrm{NaN}\left(\mathrm{SiMe}_{3}\right)_{2}(1.09 \mathrm{M}$ in THF, $0.57 \mathrm{~mL}, 0.62 \mathrm{mmol})$ at $-80{ }^{\circ} \mathrm{C}$ and gradually warmed to - 
$10{ }^{\circ} \mathrm{C}$ to generate $\mathrm{Ph}_{2} \mathrm{~S}^{13} \mathrm{CH}_{2}$. The resulting white yellow suspension was cooled to $-80{ }^{\circ} \mathrm{C}$ and transferred via canula to a Schlenk flask containing a solution of 2 (168 $\mathrm{mg}, 0.285 \mathrm{mmol})$ in THF $(11 \mathrm{~mL})$ that was also cooled to $-80^{\circ} \mathrm{C}$. The resulting mixture was allowed to warm to room temperature, stirred for $12 \mathrm{~h}$, and evaporated to dryness under reduced pressure. The brown residue was extracted with hexane $(12 \mathrm{~mL})$, and the extract was evaporated to dryness. Recrystallization of the residue from a toluene-acetonitrile $(1 \mathrm{~mL} / 4 \mathrm{~mL})$ two-layer mixture afforded brown plates of $3-{ }^{13} \mathrm{C}$, which were collected by filtration and dried in vacuo. Yield $32.8 \mathrm{mg}, 0.054 \mathrm{mmol}, 19 \%$. The ${ }^{1} \mathrm{H}$ and ${ }^{13} \mathrm{C}\left\{{ }^{1} \mathrm{H}\right\}$ NMR analysis indicated that both terminal allenic carbon atoms were equally enriched with ${ }^{13} \mathrm{C}$.

\section{$\left[\left(\mathrm{Cp}^{*} \mathrm{Ru}\right)_{2}\left(\mu-\mathrm{NC}_{6} \mathrm{H}_{5} \mathrm{CH}_{2}\right)\left(\mu-\eta^{1}: \eta^{3}-\mathrm{H}_{2} \mathrm{CCCH}_{2}\right)\right]$ (4).}

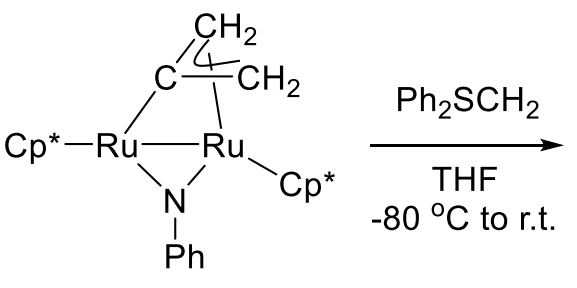

3

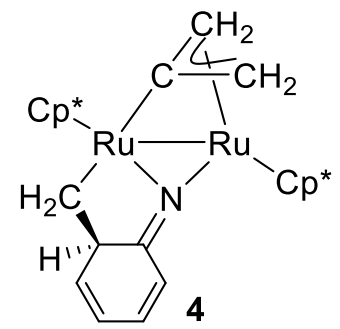

A stirred suspension of $\left[\mathrm{Ph}_{2} \mathrm{SCH}_{3}\right]\left[\mathrm{BF}_{4}\right](68 \mathrm{mg}, 0.24 \mathrm{mmol})$ in THF $(3 \mathrm{~mL})$ was treated with $\mathrm{NaN}\left(\mathrm{SiMe}_{3}\right)_{2}(1.09 \mathrm{M}$ in THF, $0.25 \mathrm{~mL}, 0.27 \mathrm{mmol})$ at $-80{ }^{\circ} \mathrm{C}$ and warmed to $-10{ }^{\circ} \mathrm{C}$ to generate $\mathrm{Ph}_{2} \mathrm{SCH}_{2}$. The resulting white yellow suspension was transferred via canula to a solution of 3 $(128 \mathrm{mg}, 0.211 \mathrm{mmol})$ in THF $(14 \mathrm{~mL})$ that was also cooled to $-80^{\circ} \mathrm{C}$. The resulting mixture was allowed to warm to room temperature, stirred for $12 \mathrm{~h}$, and then evaporated to dryness under reduced pressure. The brown residue was extracted with hexane $(20 \mathrm{~mL})$, and the extract was evaporated to dryness under reduced pressure. Recrystallization of the residue from a toluene-acetonitrile $(1 \mathrm{~mL} / 6 \mathrm{~mL})$ two-layer mixture afforded brown blocks of 4 contaminated with unreacted 3. After filtration and drying in vacuo, large crystals of $\mathbf{4}$ were separated manually. Yield $58 \mathrm{mg}, 0.094 \mathrm{mmol}, 45 \%$. Anal. Calcd (\%) for $\mathrm{C}_{30} \mathrm{H}_{41} \mathrm{NRu}_{2}$ : $\mathrm{C}$, 58.32; H, 6.69; N, 2.27. Found: C, 58.65; H, 6.80; N, 2.30. ${ }^{1} \mathrm{H}$ NMR (400 MHz, $\left.\mathrm{C}_{6} \mathrm{D}_{6}\right): \delta 6.23$ $(\mathrm{m}, 1 \mathrm{H}, \mathrm{N}=\mathrm{CCH}=\mathrm{CHCH}=\mathrm{CH}), 6.07(\mathrm{~m}, 1 \mathrm{H}, \mathrm{N}=\mathrm{CCH}=\mathrm{CHCH}=\mathrm{CH}), 6.00 \quad(\mathrm{~m}, \quad 1 \mathrm{H}$, $\mathrm{NCCH}=\mathrm{CHCH}=\mathrm{CH}), 5.92(\mathrm{~m}, 1 \mathrm{H}, \mathrm{NCCH}=\mathrm{CHCH}=\mathrm{CH}), 3.98\left(\mathrm{~m}, 1 \mathrm{H}, \mathrm{H}_{2} \mathrm{CCC}^{\prime} \mathrm{H}_{2}\right), 3.93(\mathrm{~m}$, $\left.1 \mathrm{H}, \mathrm{RuCH}_{2} \mathrm{CH}\right), 2.43$ (m, 1H, $\left.\mathrm{RuCH}_{2} \mathrm{CH}\right), 2.24$ (m, 1H, $\left.\mathrm{H}_{2} \mathrm{CCC}^{\prime} \mathrm{H}_{2}\right), 2.01$ (m, 1H, $\left.\mathrm{H}_{2} \mathrm{CCC}^{\prime} \mathrm{H}_{2}\right)$, $1.87\left(\mathrm{~m}, 1 \mathrm{H}, \mathrm{H}_{2} \mathrm{CCC}^{\prime} \mathrm{H}_{2}\right), 1.80$ (s, 15H, $\left.\mathrm{C}_{5} \mathrm{Me}_{5}\right), 1.78$ (m, $\left.1 \mathrm{H}, \mathrm{RuCH}_{2} \mathrm{CH}\right), 1.60$ (s, $15 \mathrm{H}, \mathrm{C}_{5} \mathrm{Me}_{5}$ ). ${ }^{13} \mathrm{C}\left\{{ }^{1} \mathrm{H}\right\}$ NMR (101 MHz, $\left.\mathrm{C}_{6} \mathrm{D}_{6}\right): \delta 182.0\left(\mathrm{H}_{2} \mathrm{CCC}^{\prime} \mathrm{H}_{2}\right), 156.4(\mathrm{~N}=\mathrm{CCH}=\mathrm{CHCH}=\mathrm{CH}), 139.8$ $(\mathrm{N}=\mathrm{CCH}=\mathrm{CHCH}=\mathrm{CH}), 124.4(\mathrm{~N}=\mathrm{CCH}=\mathrm{CHCH}=\mathrm{CH}), 120.9(\mathrm{~N}=\mathrm{CCH}=\mathrm{CHCH}=\mathrm{CH}), 119.7$ 
$(\mathrm{N}=\mathrm{CCH}=\mathrm{CHCH}=\mathrm{CH}), 95.9,95.8 \quad\left(C_{5} \mathrm{Me}_{5}\right), 68.8 \quad\left(\mathrm{H}_{2} \mathrm{CCC}^{\prime} \mathrm{H}_{2}\right), 63.5 \quad\left(\mathrm{H}_{2} \mathrm{CCC}^{\prime} \mathrm{H}_{2}\right), 62.1$ $\left(\mathrm{RuCH}_{2} \mathrm{CH}\right), 46.0\left(\mathrm{RuCH}_{2} \mathrm{CH}\right), 11.5,11.3\left(\mathrm{C}_{5} \mathrm{Me}_{5}\right)$.

$\left[\left(\mathrm{Cp}^{*} \mathrm{Ru}\right)_{2}(\mu-\mathrm{NPh})\left(\mu-\mathrm{CHCH}_{2} \mathrm{CH}_{3}\right)\right](5)$.

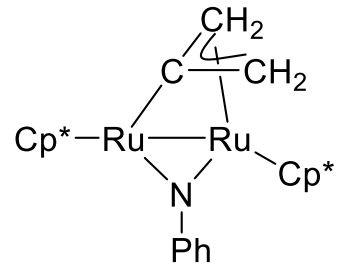

3

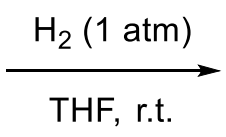

THF, r.t.<smiles>CCC1[R]2N([O+])[R]21[Te]</smiles>

5

A solution of 3 (195 mg, $0.323 \mathrm{mmol})$ in THF (14 mL) was stirred at room temperature under $\mathrm{H}_{2}(1 \mathrm{~atm})$ for $12 \mathrm{~h}$. The resulting red-brown solution was concentrated to ca. $1 \mathrm{~mL}$, and a layer of acetonitrile $(6 \mathrm{~mL})$ was added. The dark red solid that deposited was collected by filtration and dried in vacuo. Yield $105 \mathrm{mg}, 0.174 \mathrm{mmol}, 54 \%$. Anal. Calcd (\%) for $\mathrm{C}_{29} \mathrm{H}_{41} \mathrm{NRu}_{2}$ : C, 57.50; H, 6.82; N, 2.31. Found: C, 57.45; H, 7.17; N, 2.34. ${ }^{1} \mathrm{H}$ NMR (400 $\left.\mathrm{MHz}, \mathrm{C}_{6} \mathrm{D}_{6}\right): \delta 13.87\left(\mathrm{t},{ }^{3} J_{\mathrm{HH}}=4.2 \mathrm{~Hz}, 1 \mathrm{H}, \mathrm{CHCH}_{2} \mathrm{CH}_{3}\right), 7.25(\mathrm{~m}, 2 \mathrm{H}, \mathrm{Ph}), 7.08(\mathrm{~m}, 1 \mathrm{H}, \mathrm{Ph})$, $6.94(\mathrm{~m}, 2 \mathrm{H}, \mathrm{Ph}), 3.50\left(\mathrm{~m}, 2 \mathrm{H}, \mathrm{CHCH}_{2} \mathrm{CH}_{3}\right), 1.56\left(\mathrm{~s}, 30 \mathrm{H}, \mathrm{C}_{5} \mathrm{Me}_{5}\right), 1.03\left(\mathrm{t},{ }^{3} \mathrm{~J}_{\mathrm{HH}}=7.0 \mathrm{~Hz}, 3 \mathrm{H}\right.$, $\left.\mathrm{CHCH}_{2} \mathrm{CH}_{3}\right) .{ }^{13} \mathrm{C}\left\{{ }^{1} \mathrm{H}\right\}$ NMR $\left(101 \mathrm{MHz}, \mathrm{C}_{6} \mathrm{D}_{6}\right): \delta 211.2\left(\mathrm{CHCH}_{2} \mathrm{CH}_{3}\right), 168.6,127.9,121.7$, $120.0(\mathrm{Ph}), 85.4\left(\mathrm{C}_{5} \mathrm{Me}_{5}\right), 42.7\left(\mathrm{CHCH}_{2} \mathrm{CH}_{3}\right), 21.7\left(\mathrm{CHCH}_{2} \mathrm{CH}_{3}\right), 10.1\left(\mathrm{C}_{5} \mathrm{Me}_{5}\right)$.

\section{Formation of 5- $d_{2}$.}

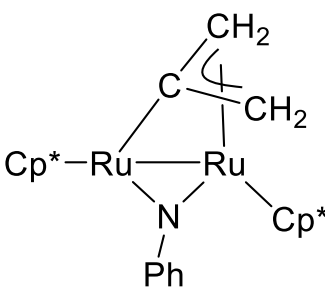

3
$\mathbf{D}_{2}(1 \mathrm{~atm})$

THF, r.t.

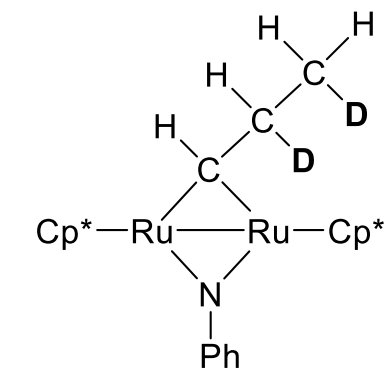

$5-d_{2}$

A solution of $3(132 \mathrm{mg}, 0.219 \mathrm{mmol})$ in THF $(7 \mathrm{~mL})$ was stirred at room temperature under $\mathrm{D}_{2}(1 \mathrm{~atm})$ for $12 \mathrm{~h}$. The resulting red-brown solution was concentrated to ca. $1 \mathrm{~mL}$, and a layer of acetonitrile $(6 \mathrm{~mL})$ was added. The dark red solid that deposited was collected by filtration and dried in vacuo. Yield $65 \mathrm{mg}, 0.106 \mathrm{mmol}, 49 \% . \quad{ }^{1} \mathrm{H}$ NMR $\left(500 \mathrm{MHz}, \mathrm{C}_{6} \mathrm{D}_{6}\right)$ : $\delta 13.87\left(\mathrm{~d},{ }^{3} J_{\mathrm{HH}}=4.3 \mathrm{~Hz}, 1 \mathrm{H}, \mathrm{CHCHDCH} 2 \mathrm{D}\right), 7.25(\mathrm{~m}, 2 \mathrm{H}, \mathrm{Ph}), 7.08(\mathrm{~m}, 1 \mathrm{H}, \mathrm{Ph}), 6.94(\mathrm{~m}$, 2H, Ph), $3.47\left(\mathrm{~m}, 1 \mathrm{H}, \mathrm{CHCHDCH}_{2} \mathrm{D}\right), 1.56\left(\mathrm{~s}, 30 \mathrm{H}, \mathrm{C}_{5} \mathrm{Me}_{5}\right), 1.00\left(\mathrm{~m}, 2 \mathrm{H}, \mathrm{CHCHDCH}_{2} \mathrm{D}\right)$. 
$\left[(\mathrm{Cp} * \mathrm{Ru})_{2}(\mu-\mathrm{NPh})\left(\mu-\mathrm{CCH}_{2} \mathrm{CH}_{3}\right)\right][\mathrm{I}]([6][\mathrm{I}])$.

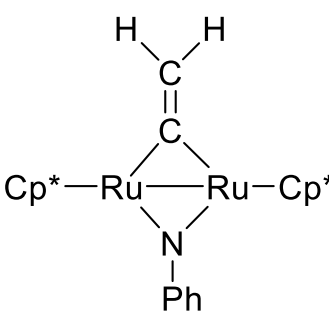

2<smiles>CCC1[R]2N([18O])[R]21[18O]</smiles>

$[6][1]$

Methyl iodide ( $36 \mu \mathrm{L}, 0.058 \mathrm{mmol}$ ) was added to a stirred suspension of 2 (33 $\mathrm{mg}, 0.056$ mmol) in toluene $(9 \mathrm{~mL})$. The resulting mixture was stirred at room temperature for $12 \mathrm{~h}$. The solid was collected by filtration and recrystallized from $\mathrm{CH}_{2} \mathrm{Cl}_{2}$-hexane. Dark red blocks that deposited were collected by filtration and dried in vacuo. Yield $30 \mathrm{mg}, 0.041 \mathrm{mmol}, 73 \%$. Anal. Calcd (\%) for $\mathrm{C}_{29} \mathrm{H}_{40} \mathrm{NIRu}_{2} \cdot \mathrm{CH}_{2} \mathrm{Cl}_{2}$ : C, 57.50; H, 6.82; N, 2.31. Found: C, 57.45; H, 7.17; $\mathrm{N}$, 2.34. ${ }^{1} \mathrm{H}$ NMR (400 MHz, $\left.\mathrm{CD}_{2} \mathrm{Cl}_{2}\right): \delta 7.50(\mathrm{~m}, 2 \mathrm{H}, \mathrm{Ph}), 7.42(\mathrm{~m}, 1 \mathrm{H}, \mathrm{Ph}), 6.69(\mathrm{~m}, 2 \mathrm{H}$, $\mathrm{Ph}), 4.47\left(\mathrm{q}, 2 \mathrm{H},{ }^{3} \mathrm{~J}_{\mathrm{HH}}=7.0 \mathrm{~Hz}, \mathrm{CCH}_{2} \mathrm{CH}_{3}\right), 1.66\left(\mathrm{~s}, 30 \mathrm{H}, \mathrm{C}_{5} \mathrm{Me}_{5}\right), 1.60\left(\mathrm{t}, 3 \mathrm{H},{ }^{3} J_{\mathrm{HH}}=7.0 \mathrm{~Hz}\right.$, $\left.\mathrm{CCH}_{2} \mathrm{CH}_{3}\right) . \quad{ }^{13} \mathrm{C}\left\{{ }^{1} \mathrm{H}\right\}$ NMR $\left(101 \mathrm{MHz}, \mathrm{CD}_{2} \mathrm{Cl}_{2}\right): \delta 391.5\left(\mathrm{CCH}_{2} \mathrm{CH}_{3}\right), 164.2,129.5,127.1$, $117.2(\mathrm{Ph}), 102.7\left(\mathrm{C}_{5} \mathrm{Me}_{5}\right), 50.0\left(\mathrm{CCH}_{2} \mathrm{CH}_{3}\right), 12.0\left(\mathrm{CCH}_{2} \mathrm{CH}_{3}\right), 10.1\left(\mathrm{C}_{5} \mathrm{Me}_{5}\right)$.

\section{Formation of $\left[\left(\mathrm{Cp}^{*} \mathrm{Ru}\right)_{2}(\mu-\mathrm{NPh})\left(\mu-\mathrm{CCH}_{2} \mathrm{CH}_{3}\right)\right]\left[\mathrm{BF}_{4}\right]\left([6]\left[\mathrm{BF}_{4}\right]\right)$.}<smiles>CCC1[R1]([O+])N1P[O+]</smiles>

5

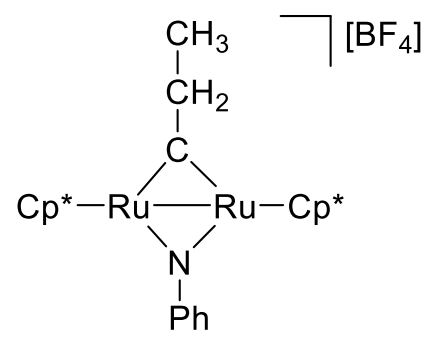

$[6]\left[\mathrm{BF}_{4}\right]$

To a solution of 5 (56 mg, $0.090 \mathrm{mmol})$ and 1,3,5-trimethoxybenzene (23 mg, $0.14 \mathrm{mmol}$, internal standard $)$ in toluene $(6 \mathrm{~mL})$ was added a solution of $\left[\mathrm{Ph}_{3} \mathrm{C}\right]\left[\mathrm{BF}_{4}\right]$ in $\mathrm{CH}_{2} \mathrm{Cl}_{2}(0.034 \mathrm{M}$, $1.8 \mathrm{~mL}, 0.061 \mathrm{mmol})$ at $-80{ }^{\circ} \mathrm{C}$. The mixture was allowed to warm to room temperature and stirred for $3 \mathrm{~h}$. The formation of $[6]\left[\mathrm{BF}_{4}\right]$ in $48 \%$ yield was confirmed by ${ }^{1} \mathrm{H}$ NMR spectroscopy. ${ }^{1} \mathrm{H}$ NMR (400 MHz, $\left.\mathrm{CD}_{2} \mathrm{Cl}_{2}\right): \delta 7.52(\mathrm{~m}, 2 \mathrm{H}, \mathrm{Ph}), 7.44(\mathrm{~m}, 1 \mathrm{H}, \mathrm{Ph}), 6.70(\mathrm{~m}$, $2 \mathrm{H}, \mathrm{Ph}), 4.49\left(\mathrm{q}, 2 \mathrm{H},{ }^{3} J_{\mathrm{HH}}=7.2 \mathrm{~Hz}, \mathrm{CCH}_{2} \mathrm{CH}_{3}\right), 1.66\left(\mathrm{~s}, 30 \mathrm{H}, \mathrm{C}_{5} \mathrm{Me}_{5}\right), 1.62\left(\mathrm{t}, 3 \mathrm{H},{ }^{3} J_{\mathrm{HH}}=7.2\right.$ $\left.\mathrm{Hz}, \mathrm{CCH}_{2} \mathrm{CH}_{3}\right)$. 


\section{$\left[(\mathrm{Cp} * \mathrm{Ru})_{2}(\mu-\mathrm{NPh})\left(\mu-\mathrm{C}=\mathrm{CHCH}_{3}\right)\right](7)$.}

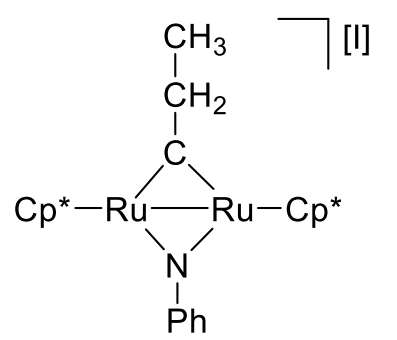

$[6][1]$

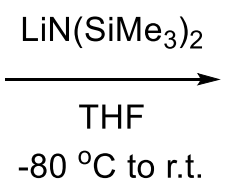

$-80^{\circ} \mathrm{C}$ to r.t.

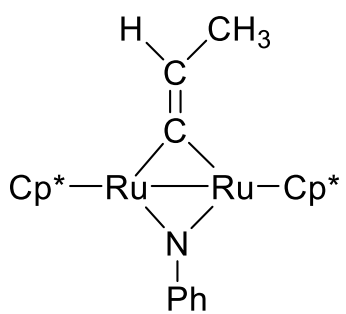

7

A stirred suspension of [6][I] (177 $\mathrm{mg}, 0.24 \mathrm{mmol})$ in THF (12 mL) was treated with $\mathrm{LiN}\left(\mathrm{SiMe}_{3}\right)_{2}(1.05 \mathrm{M}$ in THF, $0.23 \mathrm{~mL}, 0.24 \mathrm{mmol})$ at $-80{ }^{\circ} \mathrm{C}$. The resulting mixture was allowed to warm to room temperature, stirred for $12 \mathrm{~h}$, and evaporated to dryness under reduced pressure. The brown solid was washed successively with water $(12 \mathrm{~mL})$ and acetone $(9 \mathrm{~mL})$ and then dried in vacuo. Yield $75 \mathrm{mg}, 0.12 \mathrm{mmol}, 50 \%$. $\mathrm{C}_{29} \mathrm{H}_{39} \mathrm{NRu}_{2}: \mathrm{C}, 57.69 ; \mathrm{H}, 6.51 ; \mathrm{N}$, 2.32. Found: C, 57.65; H, 6.48; N, 2.20. $\left.{ }^{1} \mathrm{H} \mathrm{NMR} \mathrm{(400} \mathrm{MHz,} \mathrm{C}_{6} \mathrm{D}_{6}\right): \delta 7.29$ (m, 2H, Ph), 7.11 $(\mathrm{m}, 1 \mathrm{H}, \mathrm{Ph}), 6.97(\mathrm{~m}, 2 \mathrm{H}, \mathrm{Ph}), 6.69\left(\mathrm{q}, 1 \mathrm{H},{ }^{3} J_{\mathrm{HH}}=7.4 \mathrm{~Hz}, \mathrm{C}=\mathrm{CHCH}_{3}\right), 3.29\left(\mathrm{~d}, 3 \mathrm{H},{ }^{3} J_{\mathrm{HH}}=7.4\right.$ $\left.\mathrm{Hz}, \mathrm{C}=\mathrm{CHCH}_{3}\right), 1.46$ (br, 30H, $\left.\mathrm{C}_{5} \mathrm{Me}_{5}\right)$. Satisfactory ${ }^{13} \mathrm{C}$ NMR spectrum could not be obtained due to low solubility of 7. MS (FAB): $m / z 605\left[\mathrm{M}^{+}\right]$.

\section{$\left[\left(C p^{*} \mathrm{Ru}\right)_{2}(\mu-\mathrm{NPh})\left(\mu-\eta^{1}: \eta^{3}-\mathrm{H}_{2} \mathrm{CCCHCH}_{3}\right)\right](8)$}

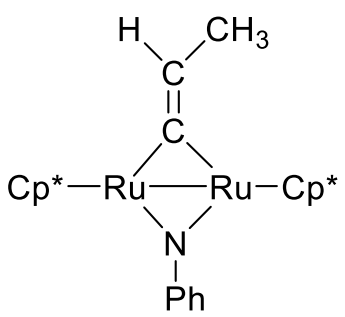

7

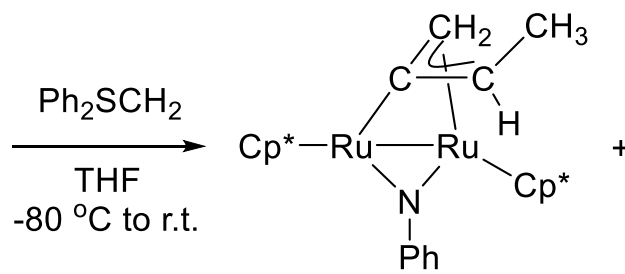

cis-8

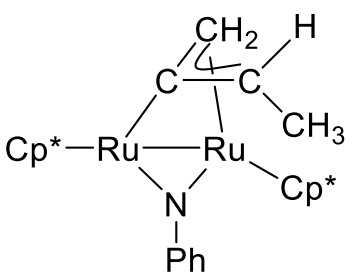

trans-8

Compound [6][I] (353 mg, $0.48 \mathrm{mmol})$ was suspended in THF (12 mL) and treated with $\mathrm{NaN}\left(\mathrm{SiMe}_{3}\right)_{2}(1.09 \mathrm{M}$ in THF, $0.44 \mathrm{~mL}, 0.48 \mathrm{mmol})$ at $-80{ }^{\circ} \mathrm{C}$ to generate 7 . Separately, a stirred suspension of $\left[\mathrm{Ph}_{2} \mathrm{SCH}_{3}\right]\left[\mathrm{BF}_{4}\right](264 \mathrm{mg}, 0.916 \mathrm{mmol})$ in THF $(6 \mathrm{~mL})$ was treated with $\mathrm{NaN}\left(\mathrm{SiMe}_{3}\right)_{2}(1.09 \mathrm{M}$ in THF, $0.91 \mathrm{~mL}, 0.99 \mathrm{mmol})$ at $-80{ }^{\circ} \mathrm{C}$ and gradually warmed to $-10{ }^{\circ} \mathrm{C}$ to generate $\mathrm{Ph}_{2} \mathrm{SCH}_{2}$. The resulting white yellow suspension was cooled to $-80{ }^{\circ} \mathrm{C}$ and transferred via canula to the mixture containing 7. The combined reaction mixture was allowed to warm to room temperature, stirred for $12 \mathrm{~h}$, and then evaporated to dryness under 
reduced pressure. The residue was extracted with hexane $(21 \mathrm{~mL})$, and the extract was evaporated to dryness under reduced pressure. The residue was recrystallized from THFacetonitrile at $-30{ }^{\circ} \mathrm{C}$, giving brown crystalline 8 (cis:trans $=5: 1$ ), which were collected by filtration and dried in vacuo. Yield $183 \mathrm{mg}, 0.30 \mathrm{mmol}, 63 \%$. Anal. Calcd (\%) for $\mathrm{C}_{30} \mathrm{H}_{41} \mathrm{NRu}_{2}$ : C, 58.32; H, 6.69; N, 2.27. Found: C, 58.40; H, 6.54; N, 2.45. ${ }^{1} \mathrm{H}$ NMR (400 $\left.\mathrm{MHz}, \mathrm{C}_{6} \mathrm{D}_{6}\right)$ for cis-8: $\delta 7.08(\mathrm{~m}, 3 \mathrm{H}, \mathrm{Ph}), 6.99(\mathrm{~m}, 2 \mathrm{H}, \mathrm{Ph}), 4.75\left(\mathrm{~d}, 1 \mathrm{H},{ }^{2} J_{\mathrm{HH}}=3.2 \mathrm{~Hz}\right.$, $\left.\mathrm{H}_{2} \mathrm{CCCHCH}_{3}\right), 4.26\left(\mathrm{~d}, 1 \mathrm{H},{ }^{2} J_{\mathrm{HH}}=3.2 \mathrm{~Hz}, \mathrm{H}_{2} \mathrm{CCCHCH}_{3}\right), 3.53\left(\mathrm{q}, 1 \mathrm{H},{ }^{3} J_{\mathrm{HH}}=7.0 \mathrm{~Hz}\right.$, $\mathrm{H}_{2} \mathrm{CCCHCH}_{3}$ ), 1.78, 1.44 (s, 15H each, $\left.\mathrm{C}_{5} \mathrm{Me}_{5}\right), 1.09$ (d, $\left.3 \mathrm{H},{ }^{3} J_{\mathrm{HH}}=7.0 \mathrm{~Hz}, \mathrm{H}_{2} \mathrm{CCCHCH}_{3}\right)$. ${ }^{13} \mathrm{C}\left\{{ }^{1} \mathrm{H}\right\}$ NMR (101 MHz, $\left.\mathrm{C}_{6} \mathrm{D}_{6}\right)$ for cis-8: $\delta 170.7\left(\mathrm{H}_{2} \mathrm{CCCHCH}_{3}\right), 160.9,128.2,120.6,117.1$ $(\mathrm{Ph}), 94.2,91.8\left(\mathrm{C}_{5} \mathrm{Me}_{5}\right), 88.6\left(\mathrm{H}_{2} \mathrm{CCCHCH}_{3}\right), 60.1\left(\mathrm{H}_{2} \mathrm{CCCHCH}_{3}\right), 17.1\left(\mathrm{H}_{2} \mathrm{CCCHCH}_{3}\right), 12.0$, $10.5\left(\mathrm{C}_{5} \mathrm{Me}_{5}\right) . \quad{ }^{1} \mathrm{H}$ NMR $\left(400 \mathrm{MHz}, \mathrm{C}_{6} \mathrm{D}_{6}\right)$ for trans-8: $\delta$ 7.12-6.88 (m, 5H, Ph), $4.58(\mathrm{~d}, 1 \mathrm{H}$, $\left.{ }^{2} J_{\mathrm{HH}}=4.2 \mathrm{~Hz}, \mathrm{H}_{2} \mathrm{CCCHCH}_{3}\right), 4.08\left(\mathrm{q}, 1 \mathrm{H},{ }^{3} J_{\mathrm{HH}}=5.6 \mathrm{~Hz}, \mathrm{H}_{2} \mathrm{CCCHCH}_{3}\right), 3.21\left(\mathrm{~d}, 1 \mathrm{H},{ }^{2} J_{\mathrm{HH}}=\right.$ $\left.4.2 \mathrm{~Hz}, \mathrm{H}_{2} \mathrm{CCCHCH}_{3}\right), 1.80,1.42\left(\mathrm{~s}, 15 \mathrm{H}\right.$ each, $\left.\mathrm{C}_{5} \mathrm{Me}_{5}\right), 1.25\left(\mathrm{~d}, 3 \mathrm{H},{ }^{3} \mathrm{~J}_{\mathrm{HH}}=5.6 \mathrm{~Hz}\right.$,

$\left.\mathrm{H}_{2} \mathrm{CCCHCH}_{3}\right) .{ }^{13} \mathrm{C}\left\{{ }^{1} \mathrm{H}\right\} \mathrm{NMR}\left(101 \mathrm{MHz}, \mathrm{C}_{6} \mathrm{D}_{6}\right)$ for trans-8: $\delta 170.8\left(\mathrm{H}_{2} \mathrm{CCCHCH}_{3}\right), 157.5$, 127.9, 120.9, $116.5(\mathrm{Ph}), 94.9,91.9\left(\mathrm{C}_{5} \mathrm{Me}_{5}\right), 94.6\left(\mathrm{H}_{2} \mathrm{CCCHCH}_{3}\right), 62.5\left(\mathrm{H}_{2} \mathrm{CCCHCH}_{3}\right), 22.8$ $\left(\mathrm{H}_{2} \mathrm{CCCHCH}_{3}\right), 12.0,10.5\left(\mathrm{C}_{5} \mathrm{Me}_{5}\right)$.

\section{Formation of $\left[\left(C p^{*} \mathrm{Ru}\right)_{2}(\mu-\mathrm{NPh})\left(\mu-\eta^{1}: \eta^{3}-\mathrm{H}_{2}{ }^{13} \mathrm{CCCHCH}\right)\right]\left(8^{-13} \mathrm{C}\right)$.}
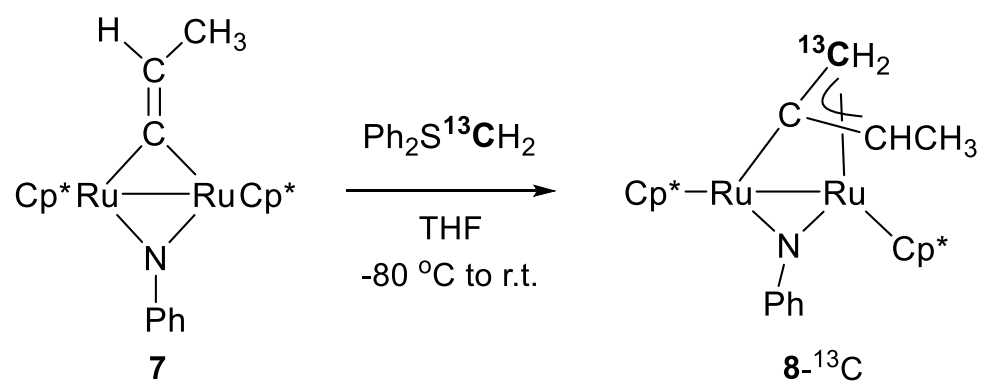

Compound [6][I] (300 mg, $0.408 \mathrm{mmol})$ was suspended in THF $(19 \mathrm{~mL})$ and treated with $\mathrm{NaN}\left(\mathrm{SiMe}_{3}\right)_{2}(1.14 \mathrm{M}$ in THF, $0.38 \mathrm{~mL}, 0.43 \mathrm{mmol})$ at $-80{ }^{\circ} \mathrm{C}$ to generate 7 . Separately, a stirred solution of $\left[\mathrm{Ph}_{2} \mathrm{~S}^{13} \mathrm{CH}_{3}\right][\mathrm{OTf}](150 \mathrm{mg}, 0.427 \mathrm{mmol})$ in THF $(9 \mathrm{~mL})$ was treated with $\mathrm{NaN}\left(\mathrm{SiMe}_{3}\right)_{2}(1.14 \mathrm{M}$ in THF, $0.38 \mathrm{~mL}, 0.43 \mathrm{mmol})$ at $-80{ }^{\circ} \mathrm{C}$ and gradually warmed to $-10{ }^{\circ} \mathrm{C}$ to generate $\mathrm{Ph}_{2} \mathrm{~S}^{13} \mathrm{CH}_{2}$. The resulting white yellow suspension was cooled to $-80{ }^{\circ} \mathrm{C}$ and transferred via canula to the mixture containing 7. The combined reaction mixture was allowed to warm to room temperature, stirred for $12 \mathrm{~h}$, and then evaporated to dryness under reduced pressure. The residue was extracted with hexane $(30 \mathrm{~mL})$, and the extract was evaporated to dryness under reduced pressure. Recrystallization of the residue from THFacetonitrile $(1 \mathrm{~mL} / 2.4 \mathrm{~mL})$ afforded brown crystalline $\mathbf{8}^{13} \mathrm{C}$ (cis:trans $\left.=5: 1\right)$, which were collected by filtration and dried in vacuo. Yield $97 \mathrm{mg}, 0.30 \mathrm{mmol}, 38 \%$. 


\section{$\left[\left(\mathrm{Cp}^{*} \mathrm{Ru}\right)_{2}(\mu-\mathrm{NPh})\left(\mu-\mathrm{CHCH}_{2} \mathrm{CH}_{2} \mathrm{CH}_{3}\right)\right](9)$.}

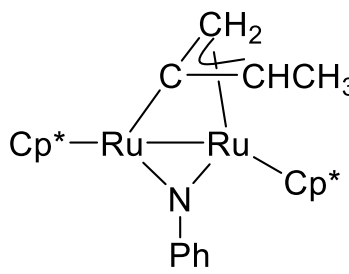

8
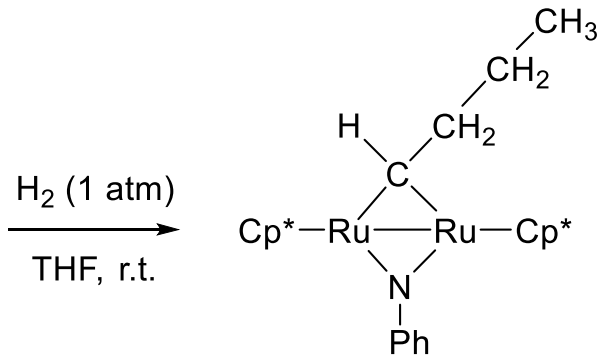

9

A solution of 8 (cis/trans mixture, $77 \mathrm{mg}, 0.13 \mathrm{mmol}$ ) in THF $(7 \mathrm{~mL})$ was stirred at room temperature under $\mathrm{H}_{2}(1 \mathrm{~atm})$ for $12 \mathrm{~h}$. The resulting red-brown solution was concentrated to ca. $1.5 \mathrm{~mL}$, and a layer of acetonitrile $(3 \mathrm{~mL})$ was added. The dark red solid that deposited was collected by filtration and dried in vacuo. Yield $52 \mathrm{mg}, 0.080 \mathrm{mmol}, 62 \%$. Anal. Calcd (\%) for $\mathrm{C}_{30} \mathrm{H}_{43} \mathrm{NRu}_{2}$ : C, 58.13; H, 6.99; N, 2.26. Found: C, 58.09; H, 7.44; N, $1.98 . \quad{ }^{1} \mathrm{H}$ NMR (400 MHz, $\left.\mathrm{C}_{6} \mathrm{D}_{6}\right): \delta 13.79\left(\mathrm{t}, 1 \mathrm{H},{ }^{3} J_{\mathrm{HH}}=3.7 \mathrm{~Hz}, \mathrm{CHCH}_{2} \mathrm{CH}_{2} \mathrm{CH}_{3}\right), 7.24(\mathrm{~m}, 2 \mathrm{H}, \mathrm{Ph}), 7.06(\mathrm{~m}$, 1H, Ph), 6.93 (m, 2H, Ph), 3.40 (m, 2H, $\left.\mathrm{CHCH}_{2} \mathrm{CH}_{2} \mathrm{CH}_{3}\right), 1.56$ (s, 30H, $\left.\mathrm{C}_{5} \mathrm{Me}_{5}\right), 1.22$ (t, 3H, $\left.{ }^{3} J_{\mathrm{HH}}=6.7 \mathrm{~Hz}, \mathrm{CHCH}_{2} \mathrm{CH}_{2} \mathrm{CH}_{3}\right), 1.16\left(\mathrm{~m}, 2 \mathrm{H}, \mathrm{CHCH}_{2} \mathrm{CH}_{2} \mathrm{CH}_{3}\right) .{ }^{13} \mathrm{C}\left\{{ }^{1} \mathrm{H}\right\} \mathrm{NMR}(101 \mathrm{MHz}$, $\left.\mathrm{C}_{6} \mathrm{D}_{6}\right): \delta 209.8\left(\mathrm{CHCH}_{2} \mathrm{CH}_{2} \mathrm{CH}_{3}\right), 169.0,128.2,122.1,120.4(\mathrm{Ph}), 85.4\left(C_{5} \mathrm{Me}_{5}\right), 54.1$ $\left(\mathrm{CHCH}_{2} \mathrm{CH}_{2} \mathrm{CH}_{3}\right), 31.9\left(\mathrm{CHCH}_{2} \mathrm{CH}_{2} \mathrm{CH}_{3}\right), 15.7\left(\mathrm{CHCH}_{2} \mathrm{CH}_{2} \mathrm{CH}_{3}\right), 10.5\left(\mathrm{C}_{5} \mathrm{Me}_{5}\right)$.

\section{Formation of 9- $d 2$.}

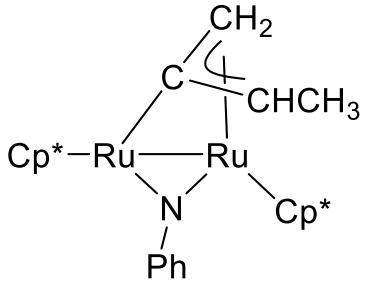

8

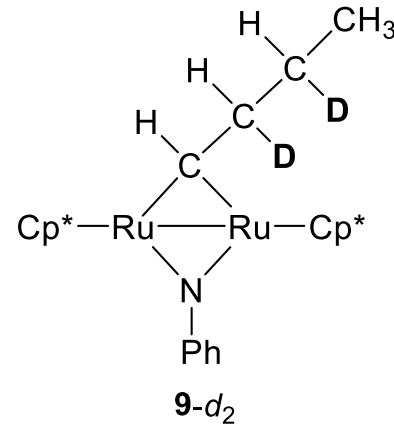

9- $d_{2}$

A solution of $8(104 \mathrm{mg}, 0.169 \mathrm{mmol})$ in THF $(8 \mathrm{~mL})$ was stirred for $3 \mathrm{~h}$ at room temperature under $\mathrm{D}_{2}(1 \mathrm{~atm})$. The solvent was removed in vacuo, and the residue was washed with hexane (2 mL). ${ }^{1} \mathrm{H}$ NMR analysis showed the formation of 9- $d_{2} .{ }^{1} \mathrm{H}$ NMR $\left(500 \mathrm{MHz}, \mathrm{C}_{6} \mathrm{D}_{6}\right): \delta$ $13.80\left(\mathrm{~d},{ }^{3} \mathrm{~J}_{\mathrm{HH}}=3.5 \mathrm{~Hz}, 1 \mathrm{H}, \mathrm{CHCHDCHDCH}\right), 7.24(\mathrm{~m}, 2 \mathrm{H}, \mathrm{Ph}), 7.07(\mathrm{~m}, 1 \mathrm{H}, \mathrm{Ph}), 6.94(\mathrm{~m}$, $2 \mathrm{H}, \mathrm{Ph}), 3.37\left(\mathrm{~m}, 1 \mathrm{H}, \mathrm{CHCHDCHDCH}_{3}\right), 1.56\left(\mathrm{~s}, 30 \mathrm{H}, \mathrm{C}_{5} \mathrm{Me}_{5}\right), 1.22\left(\mathrm{~d},{ }^{3} \mathrm{~J}_{\mathrm{HH}}=7.8 \mathrm{~Hz}, 3 \mathrm{H}\right.$, $\left.\mathrm{CHCHDCHDCH}_{3}\right) 1.09\left(\mathrm{~m}, 1 \mathrm{H}, \mathrm{CHCHDCHDCH}_{3}\right)$. 


\section{Hydrogenation of $8 \mathbf{-}^{13} \mathrm{C}$.}

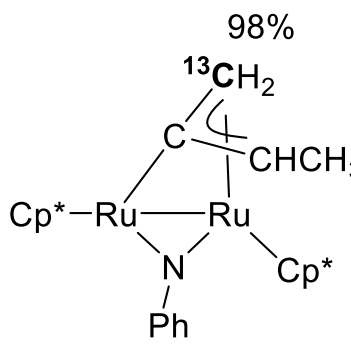

$8-{ }^{13} \mathrm{C}$

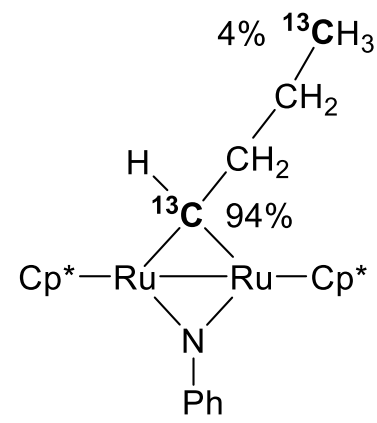

${ }^{9}{ }^{13} \mathrm{C}$

A solution of $8-{ }^{13} \mathrm{C}\left(98 \%{ }^{13} \mathrm{C}, 96.8 \mathrm{mg}, 0.156 \mathrm{mmol}\right)$ in THF $(12 \mathrm{~mL})$ was stirred for $14 \mathrm{~h}$ at room temperature under $\mathrm{H}_{2}(1 \mathrm{~atm})$. After the solution was concentrated to ca. $1 \mathrm{~mL}$ under reduced pressure, the product was crystallized by addition of a layer of acetonitrile $(3 \mathrm{~mL})$. The crystals deposited were collected by filtration and dried in vacuo. Yield $38.8 \mathrm{mg}, 0.0625$ mmol, 40\%. ${ }^{1} \mathrm{H}$ NMR (400 MHz, $\left.\mathrm{C}_{6} \mathrm{D}_{6}\right)$ for $9-{ }^{13} \mathrm{C}: \delta 13.79\left(\mathrm{dt},{ }^{1} J_{\mathrm{CH}}=135 \mathrm{~Hz},{ }^{3} J_{\mathrm{HH}}=3.6 \mathrm{~Hz}\right.$, $\left.1 \mathrm{H}, \mathrm{CHCH}_{2} \mathrm{CH}_{2} \mathrm{CH}_{3}\right), 7.24(\mathrm{~m}, 2 \mathrm{H}, \mathrm{Ph}), 7.06(\mathrm{~m}, 1 \mathrm{H}, \mathrm{Ph}), 6.93(\mathrm{~m}, 2 \mathrm{H}, \mathrm{Ph}), 3.40(\mathrm{~m}, 2 \mathrm{H}$, $\left.\mathrm{CHCH}_{2} \mathrm{CH}_{2} \mathrm{CH}_{3}\right), 1.56\left(\mathrm{~s}, 30 \mathrm{H}, \mathrm{C}_{5} \mathrm{Me}_{5}\right), 1.22\left(\mathrm{~d},{ }^{3} J_{\mathrm{HH}}=7.8 \mathrm{~Hz}, 3 \mathrm{H}, \mathrm{CHCH}_{2} \mathrm{CH}_{2} \mathrm{CH}_{3}\right) 1.11(\mathrm{~m}$, $\left.1 \mathrm{H}, \mathrm{CHCH}_{2} \mathrm{CH}_{2} \mathrm{CH}_{3}\right) .{ }^{13} \mathrm{C}\left\{{ }^{1} \mathrm{H}\right\} \mathrm{NMR}\left(101 \mathrm{MHz}, \mathrm{C}_{6} \mathrm{D}_{6}\right)$ for 9- ${ }^{13} \mathrm{C}: \delta 209.9\left(\mathrm{CHCH}_{2} \mathrm{CH}_{2} \mathrm{CH}_{3}\right)$, 169.0, 128.2, 122.1, $120.4(\mathrm{Ph}), 85.8\left(C_{5} \mathrm{Me}_{5}\right), 54.1\left(\mathrm{~d},{ }^{1} J_{\mathrm{CC}}=30.5 \mathrm{~Hz}, \mathrm{CHCH}_{2} \mathrm{CH}_{2} \mathrm{CH}_{3}\right), 31.8$ $\left(\mathrm{CHCH}_{2} \mathrm{CH}_{2} \mathrm{CH}_{3}\right), 15.7\left(\mathrm{CHCH}_{2} \mathrm{CH}_{2} \mathrm{CH}_{3}\right), 10.5\left(\mathrm{C}_{5} \mathrm{Me}_{5}\right)$.

\section{$\left[(\mathrm{Cp} * \mathrm{Ru})_{2}(\mu-\mathrm{NPh})\left(\mu-\mathrm{CCH}_{2} \mathrm{CH}_{2} \mathrm{CH}_{3}\right)\right]\left([10]\left[\mathrm{BF}_{4}\right]\right)$.}

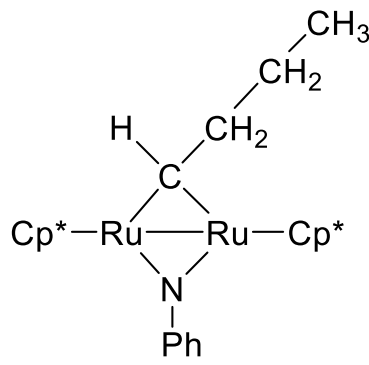

9

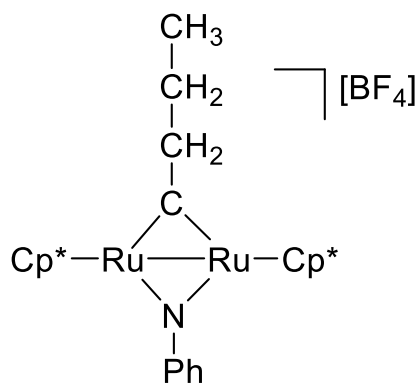

$[10]\left[\mathrm{BF}_{4}\right]$

Complex 9 (284 mg, $0.46 \mathrm{mmol})$ was dissolved in toluene $(9 \mathrm{~mL})$. The solution was cooled to $-90{ }^{\circ} \mathrm{C}$, and a solution of $\left[\mathrm{Ph}_{3} \mathrm{C}\right]\left[\mathrm{BF}_{4}\right]$ in $\mathrm{CH}_{2} \mathrm{Cl}_{2}(0.16 \mathrm{M}, 3 \mathrm{~mL}, 0.48 \mathrm{mmol})$ was added dropwise. The mixture was gradually warmed to room temperature and stirred for $4 \mathrm{~h}$. The solvent was removed in vacuo, and the residue was washed successively with hexane $(5 \mathrm{~mL})$ and THF $(10 \mathrm{~mL})$ and dried in vacuo to afford $[\mathbf{1 0}]\left[\mathrm{BF}_{4}\right]$ as a reddish brown solid. Yield 122 
mg, $0.173 \mathrm{mmol}, 38 \%$. ${ }^{1} \mathrm{H}$ NMR (400 MHz, acetone- $\left.d_{6}\right): \delta 7.59(\mathrm{~m}, 2 \mathrm{H}, \mathrm{Ph}), 7.48(\mathrm{~m}, 1 \mathrm{H}$, $\mathrm{Ph}), 6.88(\mathrm{~m}, 2 \mathrm{H}, \mathrm{Ph}), 4.55\left(\mathrm{~m}, 2 \mathrm{H}, \mathrm{CCH}_{2} \mathrm{CH}_{2} \mathrm{CH}_{3}\right), 2.08\left(\mathrm{~m}, 2 \mathrm{H}, \mathrm{CCH}_{2} \mathrm{CH}_{2} \mathrm{CH}_{3}\right), 1.72(\mathrm{~s}, 30 \mathrm{H}$, $\left.\mathrm{C}_{5} \mathrm{Me}_{5}\right), 1.39\left(\mathrm{t}, 3 \mathrm{H},{ }^{3} J_{\mathrm{HH}}=7.2 \mathrm{~Hz}, \mathrm{CCH}_{2} \mathrm{CH}_{2} \mathrm{CH}_{3}\right) . \quad{ }^{13} \mathrm{C}\left\{{ }^{1} \mathrm{H}\right\}$ NMR $\left(101 \mathrm{MHz}\right.$, acetone- $\left.d_{6}\right): \delta$ $390.4\left(\mathrm{CCH}_{2} \mathrm{CH}_{2} \mathrm{CH}_{3}\right), 165.0,130.1,127.6,118.2(\mathrm{Ph}), 103.4\left(\mathrm{C}_{5} \mathrm{Me}_{5}\right), 59.8\left(\mathrm{CCH}_{2} \mathrm{CH}_{2} \mathrm{CH}_{3}\right)$, $22.3\left(\mathrm{CCH}_{2} \mathrm{CH}_{2} \mathrm{CH}_{3}\right), 14.3\left(\mathrm{CCH}_{2} \mathrm{CH}_{2} \mathrm{CH}_{3}\right), 10.0\left(\mathrm{C}_{5} \mathrm{Me}_{5}\right)$.

$\left[(\mathrm{Cp} * \mathrm{Ru})_{2}(\mu-\mathrm{NPh})\left(\mu-\mathrm{C}=\mathrm{CHCH}_{2} \mathrm{CH}_{3}\right)\right](11)$.

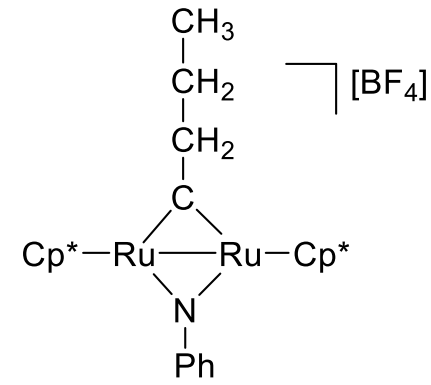

$[10]\left[\mathrm{BF}_{4}\right]$

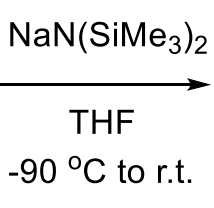
$-90{ }^{\circ} \mathrm{C}$ to r.t.

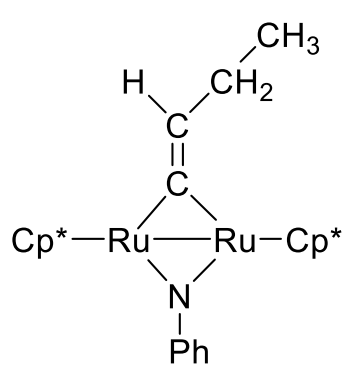

11

To a stirred suspension of $[\mathbf{1 0}]\left[\mathrm{BF}_{4}\right](122 \mathrm{mg}, 0.173 \mathrm{mmol})$ in THF $(8 \mathrm{~mL})$ was added a solution of $\mathrm{NaN}\left(\mathrm{SiMe}_{3}\right)_{2}$ in $\mathrm{THF}(1.05 \mathrm{M}, 0.16 \mathrm{~mL}, 0.17 \mathrm{mmol})$ at $-90{ }^{\circ} \mathrm{C}$. The resulting mixture was gradually warmed to room temperature and stirred for $12 \mathrm{~h}$. The solvent was removed in vacuo, and the residue was washed successively with water $(2 \mathrm{~mL})$ and acetonitrile $(4 \mathrm{~mL})$ and dried in vacuo, giving 11 as a dark green solid. Yield $98 \mathrm{mg}, 0.16 \mathrm{mmol}, 92 \%$. ${ }^{1} \mathrm{H}$ NMR (400 MHz, $\mathrm{C}_{6} \mathrm{D}_{6}$ ): $\delta 7.30$ (m, 2H, Ph), 7.11 (m, 1H, Ph), 6.97 (m, 2H, Ph), 6.55 (t, 1H, ${ }^{3} J_{\mathrm{HH}}=7.2 \mathrm{~Hz}, \mathrm{C}=\mathrm{CHCH}_{2} \mathrm{CH}_{3}$ ), 3.64 (quin, $2 \mathrm{H},{ }^{3} \mathrm{~J}_{\mathrm{HH}}=7.2 \mathrm{~Hz}, \mathrm{C}=\mathrm{CHCH}_{2} \mathrm{CH}_{3}$ ), $1.78(\mathrm{t}, 3 \mathrm{H}$, $\left.{ }^{3} J_{\mathrm{HH}}=7.2 \mathrm{~Hz}, \mathrm{C}=\mathrm{CHCH}_{2} \mathrm{CH} \mathrm{H}_{3}\right), 1.45\left(\mathrm{br}, 30 \mathrm{H}, \mathrm{C}_{5} \mathrm{Me}_{5}\right) .{ }^{13} \mathrm{C}\left\{{ }^{1} \mathrm{H}\right\} \mathrm{NMR}\left(101 \mathrm{MHz}, \mathrm{C}_{6} \mathrm{D}_{6}\right): \delta$ $295.4\left(C=\mathrm{CHCH}_{2} \mathrm{CH}_{3}\right), 168.6,128.3,123.0,120.0(\mathrm{Ph}), 129.6\left(\mathrm{C}=\mathrm{CHCH}_{2} \mathrm{CH}_{3}\right), 90.0,89.5$ $\left(C_{5} \mathrm{Me}_{5}\right), 29.1\left(\mathrm{C}=\mathrm{CHCH}_{2} \mathrm{CH}_{3}\right), 19.1\left(\mathrm{C}=\mathrm{CHCH}_{2} \mathrm{CH}_{3}\right), 11.6,9.57$ (br, $\left.\mathrm{C}_{5} \mathrm{Me}_{5}\right)$. 
$\left[\left(\mathrm{Cp}^{*} \mathrm{Ru}\right)_{2}(\mu-\mathrm{NPh})\left(\mu-\mathrm{CHCH}_{2} \mathrm{CH}_{2} \mathrm{CH}_{2} \mathrm{CH}_{3}\right)\right](13)$.

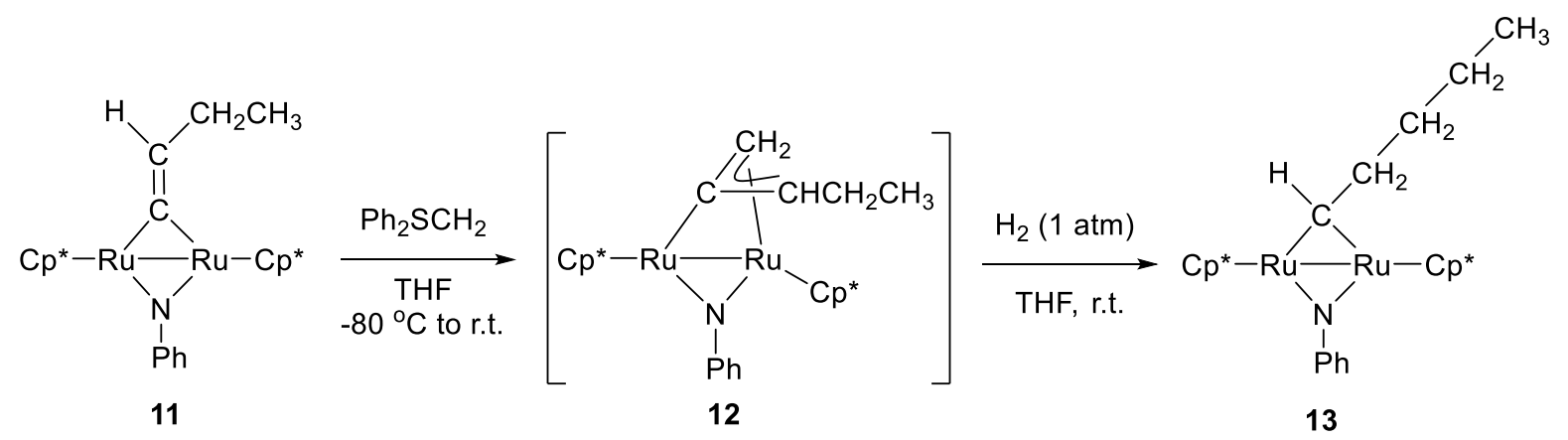

A stirred solution of $\left[\mathrm{Ph}_{2} \mathrm{SCH}_{3}\right][\mathrm{OTf}](50 \mathrm{mg}, 0.143 \mathrm{mmol})$ in THF $(7 \mathrm{~mL})$ was treated with a solution of $\mathrm{NaN}\left(\mathrm{SiMe}_{3}\right)_{2}$ in THF $(1.09 \mathrm{M}, 0.136 \mathrm{~mL}, 0.149 \mathrm{mmol})$ at $-80{ }^{\circ} \mathrm{C}$ and gradually warmed to $-10{ }^{\circ} \mathrm{C}$ to generate $\mathrm{Ph}_{2} \mathrm{SCH}_{2}$. The resulting yellow solution was added via canula to a solution of $11(85.5 \mathrm{mg}, 0.135 \mathrm{mmol})$ in THF $(8 \mathrm{~mL})$ that was also cooled to $-80{ }^{\circ} \mathrm{C}$. The resulting mixture was warmed to room temperature and stirred for $4 \mathrm{~h}$. The solvent was removed in vacuo, and the residue was extracted with toluene $(14 \mathrm{~mL})$. After removal of the solvent, a mixture containing 12 and $\mathrm{Ph}_{2} \mathrm{~S}$ was obtained. Attempts to purify 12 were unsuccessful due to the high solubility of this compound in organic solvents. ${ }^{1} \mathrm{H}$ NMR (400 $\left.\mathrm{MHz}, \mathrm{C}_{6} \mathrm{D}_{6}\right)$ for cis-12: $\delta 4.74\left(\mathrm{~m}, 1 \mathrm{H}, \mathrm{H}_{2} \mathrm{CCCHCH}_{2} \mathrm{CH}_{3}\right), 4.18\left(\mathrm{~m}, 1 \mathrm{H}, \mathrm{H}_{2} \mathrm{CCCHCH}_{2} \mathrm{CH}_{3}\right)$, $3.98\left(\mathrm{~m}, 1 \mathrm{H}, \mathrm{H}_{2} \mathrm{CCCHCH}_{2} \mathrm{CH}_{3}\right), 1.78,1.44$ (s, $15 \mathrm{H}$ each, $\left.\mathrm{C}_{5} \mathrm{Me}_{5}\right), 1.09$ (m, 2H, $\left.\mathrm{H}_{2} \mathrm{CCCHCH}_{2} \mathrm{CH}_{3}\right), 1.05\left(\mathrm{t}, 3 \mathrm{H},{ }^{3} J_{\mathrm{HH}}=7.2 \mathrm{~Hz}, \mathrm{H}_{2} \mathrm{CCCHCH}_{2} \mathrm{CH}_{3}\right) . \quad{ }^{1} \mathrm{H} \mathrm{NMR}\left(400 \mathrm{MHz}, \mathrm{C}_{6} \mathrm{D}_{6}\right)$ for trans-12: $\delta 4.57\left(\mathrm{~m}, 1 \mathrm{H}, \mathrm{H}_{2} \mathrm{CCCHCH}_{2} \mathrm{CH}_{3}\right), 3.98\left(\mathrm{~m}, 1 \mathrm{H}, \mathrm{H}_{2} \mathrm{CCCHCH}_{2} \mathrm{CH}_{3}\right), 3.21(\mathrm{~m}, 1 \mathrm{H}$, $\mathrm{H}_{2} \mathrm{CCCHCH}_{2} \mathrm{CH}_{3}$ ), 1.79, 1.46 (s, 15H each, $\mathrm{C}_{5} \mathrm{Me}_{5}$ ), 1.09 (m, 2H, $\left.\mathrm{H}_{2} \mathrm{CCCHCH}_{2} \mathrm{CH}_{3}\right), 0.90$ (m, $\left.3 \mathrm{H}, \mathrm{H}_{2} \mathrm{CCCHCH}_{2} \mathrm{CH}_{3}\right)$.

The mixture was then dissolved in THF $(4 \mathrm{~mL})$, and the solution was stirred under $\mathrm{H}_{2}(1 \mathrm{~atm})$ at room temperature for $12 \mathrm{~h}$. After the solvent was removed in vacuo, the residue was washed twice with acetonitrile ( $3 \mathrm{~mL}$ ), leaving 13 as a dark red solid. Yield $37 \mathrm{mg}, 0.058 \mathrm{mmol}, 43 \%$ based on 11. ${ }^{1} \mathrm{H}$ NMR (400 MHz, $\left.\mathrm{C}_{6} \mathrm{D}_{6}\right): \delta 13.82\left(\mathrm{t}, 1 \mathrm{H},{ }^{3} \mathrm{~J}_{\mathrm{HH}}=3.2 \mathrm{~Hz}, \mathrm{CHCH}_{2} \mathrm{CH}_{2} \mathrm{CH}_{2} \mathrm{CH}_{3}\right)$, $7.23(\mathrm{~m}, 2 \mathrm{H}, \mathrm{Ph}), 7.06$ (m, 1H, Ph), $6.92(\mathrm{~m}, 2 \mathrm{H}, \mathrm{Ph}), 3.43\left(\mathrm{~m}, 2 \mathrm{H}, \mathrm{CHCH}_{2} \mathrm{CH}_{2} \mathrm{CH}_{2} \mathrm{CH}_{3}\right), 1.62$ (m, $\left.2 \mathrm{H}, \mathrm{CHCH}_{2} \mathrm{CH}_{2} \mathrm{CH}_{2} \mathrm{CH}_{3}\right), 1.57$ (s, 30H, $\left.\mathrm{C}_{5} \mathrm{Me}_{5}\right), 1.13$ (m,2H, $\left.\mathrm{CHCH}_{2} \mathrm{CH}_{2} \mathrm{CH}_{2} \mathrm{CH}_{3}\right), 1.04$ (t, $\left.3 \mathrm{H},{ }^{3} J_{\mathrm{HH}}=7.2 \mathrm{~Hz}, \mathrm{CHCH}_{2} \mathrm{CH}_{2} \mathrm{CH}_{2} \mathrm{CH}_{3}\right) . \quad{ }^{13} \mathrm{C}\left\{{ }^{1} \mathrm{H}\right\} \mathrm{NMR}\left(101 \mathrm{MHz}, \mathrm{C}_{6} \mathrm{D}_{6}\right): \delta 209.7$

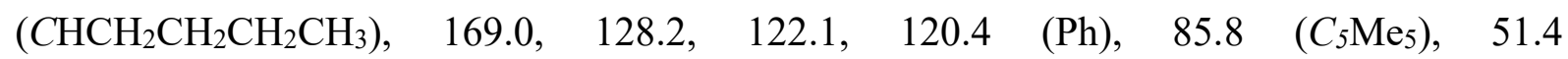
$\left(\mathrm{CHCH}_{2} \mathrm{CH}_{2} \mathrm{CH}_{2} \mathrm{CH}_{3}\right), \quad 40.8 \quad\left(\mathrm{CHCH}_{2} \mathrm{CH}_{2} \mathrm{CH}_{2} \mathrm{CH}_{3}\right), \quad 24.7 \quad\left(\mathrm{CHCH}_{2} \mathrm{CH}_{2} \mathrm{CH}_{2} \mathrm{CH}_{3}\right), \quad 15.0$ $\left(\mathrm{CHCH}_{2} \mathrm{CH}_{2} \mathrm{CH}_{2} \mathrm{CH}_{3}\right), 10.5\left(\mathrm{C}_{5} \mathrm{Me}_{5}\right)$. 
$\left[(\mathrm{Cp} * \mathrm{Ru})_{2}(\mu-\mathrm{NPh})\left(\mu-\mathrm{CCH}_{2} \mathrm{CH}_{2} \mathrm{CH}_{2} \mathrm{CH}_{3}\right)\right]\left([14]\left[\mathrm{BF}_{4}\right]\right)$.

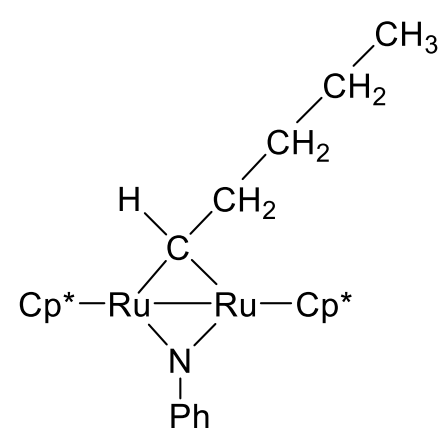

13

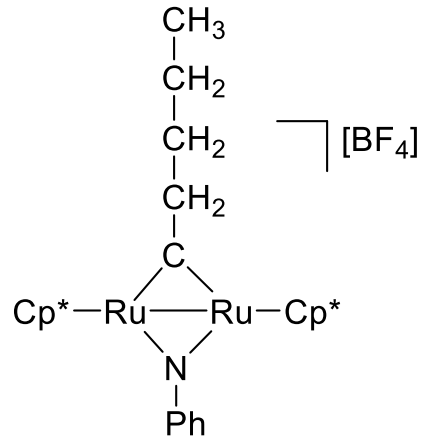

$[14]\left[\mathrm{BF}_{4}\right]$

Complex 13 (345 mg, $0.54 \mathrm{mmol})$ was dissolved in toluene $(10 \mathrm{~mL})$. The solution was cooled to $-90{ }^{\circ} \mathrm{C}$, and a solution of $\left[\mathrm{Ph}_{3} \mathrm{C}\right]\left[\mathrm{BF}_{4}\right]$ in $\mathrm{CH}_{2} \mathrm{Cl}_{2}(0.20 \mathrm{M}, 3 \mathrm{~mL}, 0.60 \mathrm{mmol})$ was added dropwise. The mixture was gradually warmed to room temperature and stirred for $4 \mathrm{~h}$. The solvent was removed in vacuo, and the residue was washed successively with hexane (5 $\mathrm{mL})$ and THF $(10 \mathrm{~mL})$ and dried in vacuo to afford $[14]\left[\mathrm{BF}_{4}\right]$ as a reddish brown solid. Yield $151 \mathrm{mg}, 0.210 \mathrm{mmol}, 39 \%$. $\quad{ }^{1} \mathrm{H}$ NMR $\left(\mathrm{CD}_{3} \mathrm{CN}\right): \delta 7.52(\mathrm{~m}, 2 \mathrm{H}, \mathrm{Ph}), 7.43(\mathrm{~m}, 1 \mathrm{H}, \mathrm{Ph}), 6.76$ (m, 2H, Ph), 4.46 (m, 2H, $\left.\mathrm{CCH}_{2} \mathrm{CH}_{2} \mathrm{CH}_{2} \mathrm{CH}_{3}\right), 1.95$ (m, 2H, $\left.\mathrm{CCH}_{2} \mathrm{CH}_{2} \mathrm{CH}_{2} \mathrm{CH}_{3}\right), 1.83$ (m, 2H, $\mathrm{CCH}_{2} \mathrm{CH}_{2} \mathrm{CH}_{2} \mathrm{CH}_{3}$ ), 1.64 (s, 30H, $\mathrm{C}_{5} \mathrm{Me}_{5}$ ), 1.12 (t, $3 \mathrm{H},{ }^{3} \mathrm{~J}_{\mathrm{HH}}=7.2 \mathrm{~Hz}, \mathrm{CCH}_{2} \mathrm{CH}_{2} \mathrm{CH}_{2} \mathrm{CH}_{3}$ ). ${ }^{13} \mathrm{C}\left\{{ }^{1} \mathrm{H}\right\}$ NMR $\left(\mathrm{CD}_{3} \mathrm{CN}\right): \delta 390.8\left(\mathrm{CCH}_{2} \mathrm{CH}_{2} \mathrm{CH}_{2} \mathrm{CH}_{3}\right), 164.9,130.1,127.6,118.3(\mathrm{Ph}), 103.5$ $\left(\mathrm{C}_{5} \mathrm{Me}_{5}\right), 57.9\left(\mathrm{CCH}_{2} \mathrm{CH}_{2} \mathrm{CH}_{2} \mathrm{CH}_{3}\right), 30.8\left(\mathrm{CCH}_{2} \mathrm{CH}_{2} \mathrm{CH}_{2} \mathrm{CH}_{3}\right), 23.7\left(\mathrm{CCH}_{2} \mathrm{CH}_{2} \mathrm{CH}_{2} \mathrm{CH}_{3}\right), 14.2$ $\left(\mathrm{CCH}_{2} \mathrm{CH}_{2} \mathrm{CH}_{2} \mathrm{CH}_{3}\right), 10.2\left(\mathrm{C}_{5} \mathrm{Me}_{5}\right)$.

\section{$\left[\left(\mathrm{Cp}^{*} \mathrm{Ru}\right)_{2}(\mu-\mathrm{NPh})\left(\mu-\mathrm{C}=\mathrm{CHCH}_{2} \mathrm{CH}_{2} \mathrm{CH}_{3}\right)\right](15)$.}

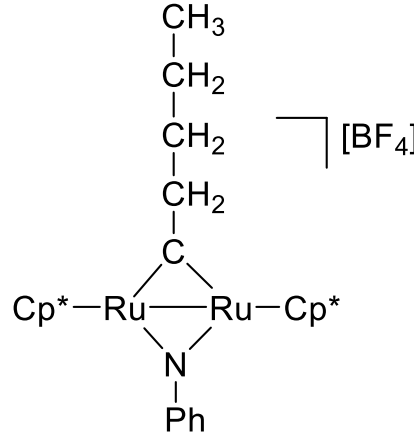

$[14]\left[\mathrm{BF}_{4}\right]$

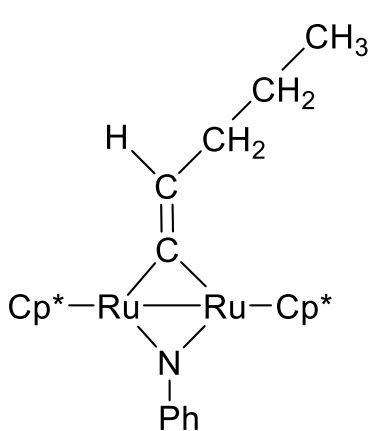

15

To a stirred suspension of $[\mathbf{1 4}]\left[\mathrm{BF}_{4}\right](381 \mathrm{mg}, 0.53 \mathrm{mmol})$ in THF $(20 \mathrm{~mL})$ was added a solution of $\mathrm{NaN}\left(\mathrm{SiMe}_{3}\right)_{2}$ in THF $(1.2 \mathrm{M}, 0.70 \mathrm{~mL}, 0.58 \mathrm{mmol})$ at $-80{ }^{\circ} \mathrm{C}$. The resulting mixture was gradually warmed to room temperature and stirred for $6 \mathrm{~h}$. The solvent was 
removed in vacuo, and the residue was washed successively with water $(3 \mathrm{~mL})$ and acetonitrile $(3 \mathrm{~mL})$ and dried in vacuo to give 15 as a dark green solid. Yield $287 \mathrm{mg}, 0.454 \mathrm{mmol}, 86 \%$. ${ }^{1} \mathrm{H}$ NMR $\left(\mathrm{C}_{6} \mathrm{D}_{6}\right): \delta 7.30(\mathrm{~m}, 2 \mathrm{H}, \mathrm{Ph}), 7.11(\mathrm{~m}, 1 \mathrm{H}, \mathrm{Ph}), 6.98(\mathrm{~m}, 2 \mathrm{H}, \mathrm{Ph}), 6.60\left(\mathrm{t}, 1 \mathrm{H},{ }^{3} \mathrm{~J}_{\mathrm{HH}}=7.3\right.$ $\left.\mathrm{Hz}, \mathrm{C}=\mathrm{CHCH}_{2} \mathrm{CH}_{2} \mathrm{CH}_{3}\right), 3.63\left(\mathrm{q}, 2 \mathrm{H},{ }^{3} J_{\mathrm{HH}}=7.3 \mathrm{~Hz}, \mathrm{C}=\mathrm{CHCH}_{2} \mathrm{CH}_{2} \mathrm{CH}_{3}\right), 2.18\left(\right.$ sext, $2 \mathrm{H},{ }^{3} J_{\mathrm{HH}}$ $\left.=7.3 \mathrm{~Hz}, \mathrm{C}=\mathrm{CHCH}_{2} \mathrm{CH}_{2} \mathrm{CH}_{3}\right), 1.46\left(\mathrm{t}, 3 \mathrm{H},{ }^{3} \mathrm{~J}_{\mathrm{HH}}=7.3 \mathrm{~Hz}, \mathrm{C}=\mathrm{CHCH}_{2} \mathrm{CH}_{2} \mathrm{CH}_{3}\right), 1.43(\mathrm{br} \mathrm{s}, 30 \mathrm{H}$, $\left.\mathrm{C}_{5} \mathrm{Me}_{5}\right) . \quad{ }^{13} \mathrm{C}\left\{{ }^{1} \mathrm{H}\right\} \operatorname{NMR}\left(\mathrm{C}_{6} \mathrm{D}_{6}\right): \delta 295.8\left(C=\mathrm{CHCH}_{2} \mathrm{CH}_{2} \mathrm{CH}_{3}\right), 168.6,127.5,127.1,123.0$ $(\mathrm{Ph}), \quad 120.0\left(\mathrm{C}=\mathrm{CHCH}_{2} \mathrm{CH}_{2} \mathrm{CH}_{3}\right), \quad 89.9,89.5 \quad\left(\mathrm{C}_{5} \mathrm{Me}_{5}\right), \quad 38.2 \quad\left(\mathrm{C}=\mathrm{CHCH}_{2} \mathrm{CH}_{2} \mathrm{CH}_{3}\right), 27.8$ $\left(\mathrm{C}=\mathrm{CHCH}_{2} \mathrm{CH}_{2} \mathrm{CH}_{3}\right), 14.9\left(\mathrm{C}=\mathrm{CHCH}_{2} \mathrm{CH}_{2} \mathrm{CH}_{3}\right)$, 11.6, $9.62\left(\mathrm{C}_{5} \mathrm{Me}_{5}\right)$.

\section{$\left[\left(\mathrm{Cp}^{*} \mathrm{Ru}\right)_{2}(\mu-\mathrm{NPh})\left(\mu-\mathrm{CHCH}_{2} \mathrm{CH}_{2} \mathrm{CH}_{2} \mathrm{CH}_{2} \mathrm{CH}_{3}\right)\right](17)$}

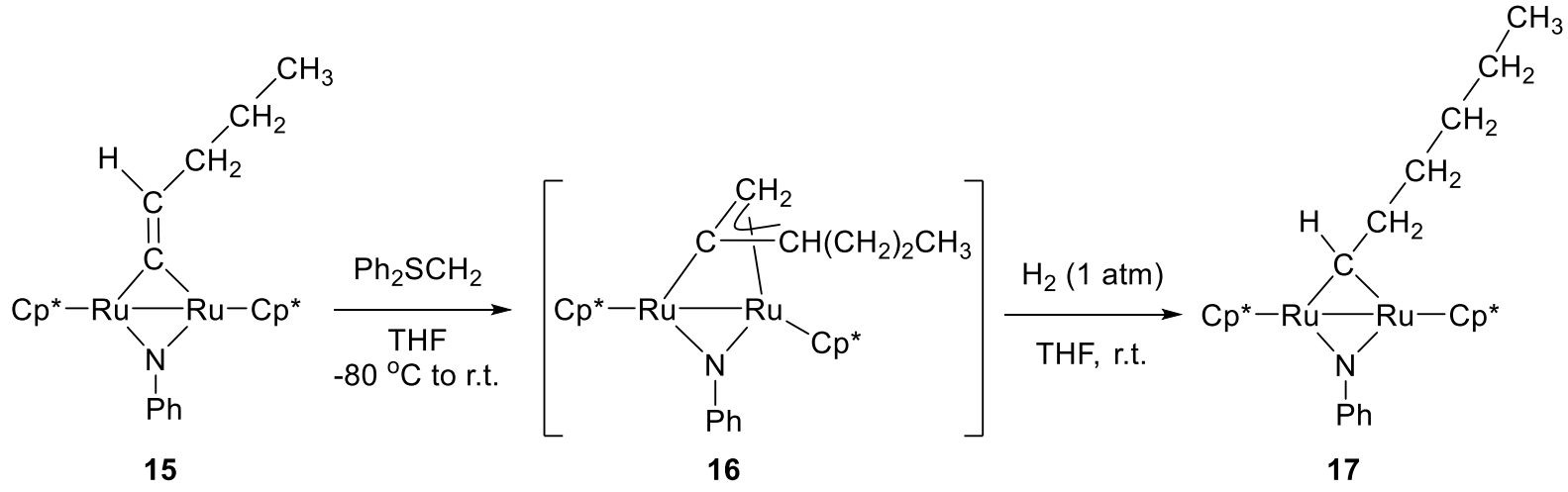

A stirred solution of $\left[\mathrm{Ph}_{2} \mathrm{SCH}_{3}\right][\mathrm{OTf}](126 \mathrm{mg}, 0.36 \mathrm{mmol})$ in THF $(7 \mathrm{~mL})$ was treated with a solution of $\mathrm{NaN}\left(\mathrm{SiMe}_{3}\right)_{2}$ in $\mathrm{THF}(1.09 \mathrm{M}, 0.34 \mathrm{~mL}, 0.36 \mathrm{mmol})$ at $-80{ }^{\circ} \mathrm{C}$ and gradually warmed to $-10{ }^{\circ} \mathrm{C}$ to generate $\mathrm{Ph}_{2} \mathrm{SCH}_{2}$. The resulting yellow solution was added via canula to a solution of $15(192 \mathrm{mg}, 0.30 \mathrm{mmol})$ in THF $(10 \mathrm{~mL})$ that was also cooled to $-80{ }^{\circ} \mathrm{C}$. The resulting mixture was allowed to warm to room temperature and stirred overnight. The solvent was removed in vacuo, and the residue was extracted with toluene $(15 \mathrm{~mL})$. After removal of the solvent, the residue was dissolved in THF $(5 \mathrm{~mL})$, and the solution was stirred under $\mathrm{H}_{2}(1 \mathrm{~atm})$ at room temperature for $24 \mathrm{~h}$. Recrystallization from THF-acetonitrile afforded $\mathbf{1 7}$ as a dark red crystalline solid, which was collected by filtration and dried in vacuo. Yield $133 \mathrm{mg}, 0.205 \mathrm{mmol}, 68 \%$ based on 15. ${ }^{1} \mathrm{H}$ NMR $\left(\mathrm{C}_{6} \mathrm{D}_{6}\right): \delta 13.82\left(\mathrm{t}, 1 \mathrm{H},{ }^{3} J_{\mathrm{HH}}=3.6 \mathrm{~Hz}\right.$, $\left.\mathrm{CHCH}_{2} \mathrm{CH}_{2} \mathrm{CH}_{2} \mathrm{CH}_{2} \mathrm{CH}_{3}\right), 7.23$ (m, 2H , Ph), 7.06 (m, 1H, Ph), $6.92(\mathrm{~m}, 2 \mathrm{H}, \mathrm{Ph}), 3.43$ (m, 2H, $\left.\mathrm{CH}_{2}\right), 1.57$ (s, 30H, $\left.\mathrm{C}_{5} \mathrm{Me}_{5}\right), 1.59-1.44\left(\mathrm{~m}, 4 \mathrm{H}, \mathrm{CH}_{2}\right), 1.13\left(\mathrm{~m}, 2 \mathrm{H}, \mathrm{CH}_{2}\right), 0.97\left(\mathrm{t}, 3 \mathrm{H},{ }^{3} J_{\mathrm{HH}}=7.6\right.$ $\left.\mathrm{Hz}, \mathrm{CHCH}_{2} \mathrm{CH}_{2} \mathrm{CH}_{2} \mathrm{CH}_{2} \mathrm{CH}_{3}\right) .{ }^{13} \mathrm{C}\left\{{ }^{1} \mathrm{H}\right\} \mathrm{NMR}\left(\mathrm{C}_{6} \mathrm{D}_{6}\right): \delta 209.8\left(\mathrm{CHCH}_{2} \mathrm{CH}_{2} \mathrm{CH}_{2} \mathrm{CH}_{2} \mathrm{CH}_{3}\right)$, 168.9, 128.2, 122.1, $120.4(\mathrm{Ph}), 85.8\left(C_{5} \mathrm{Me}_{5}\right)$, 51.7, 38.4, 34.2, $23.8\left(\mathrm{CH}_{2}\right), 14.9$ $\left(\mathrm{CHCH}_{2} \mathrm{CH}_{2} \mathrm{CH}_{2} \mathrm{CH}_{3}\right), 10.5\left(\mathrm{C}_{5} \mathrm{Me}_{5}\right)$. 
$\left[(\mathrm{Cp} * \mathrm{Ru})_{2}(\mu-\mathrm{NPh})\left(\mu-\mathrm{C}\left(\mathrm{CH}_{2}\right)_{2}\right)\right](\mathbf{1 8})$.

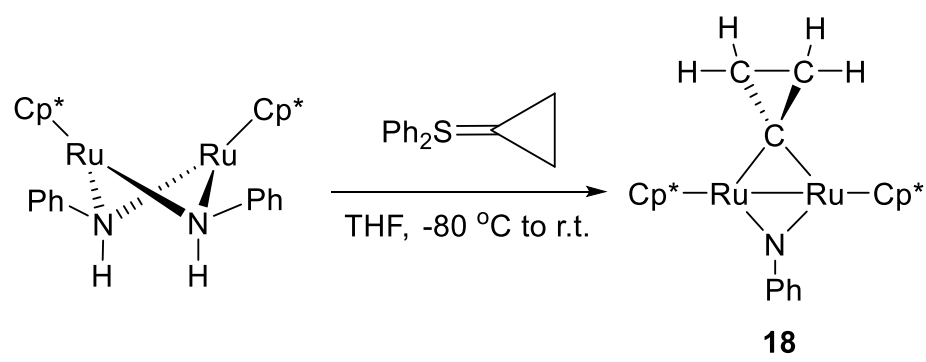

A stirred suspension of cyclopropyldiphenylsulfonium tetrafluoroborate $(150 \mathrm{mg}, 0.478$ $\mathrm{mmol})$ in THF $(6 \mathrm{~mL})$ was treated with a solution of $\mathrm{NaN}\left(\mathrm{SiMe}_{3}\right)_{2}$ in $\mathrm{THF}(1.09 \mathrm{M}, 0.44 \mathrm{~mL}$, $0.48 \mathrm{mmol}$ ) at $-80{ }^{\circ} \mathrm{C}$ and gradually warmed to $-10{ }^{\circ} \mathrm{C}$ to generate the diphenylsulfonium cyclopropylide. The resulting yellow slurry was cooled to $-80^{\circ} \mathrm{C}$ and was transferred via canula to a solution of $[\mathrm{Cp} * \mathrm{Ru}(\mu-\mathrm{NHPh})]_{2}(309 \mathrm{mg}, 0.471 \mathrm{mmol})$ in THF $(14 \mathrm{~mL})$ that was also cooled to $-80{ }^{\circ} \mathrm{C}$. The resulting mixture was warmed gradually to room temperature and stirred for $2 \mathrm{~h}$. The solvent was removed in vacuo, and the residue was extracted with toluene $(18 \mathrm{~mL})$. The solution was concentrated to ca. $3 \mathrm{~mL}$, and a layer of acetonitrile $(12 \mathrm{~mL})$ was added. After 3 days, the dark brown solid that deposited was collected by filtration and dried in vacuo. Yield $149 \mathrm{mg}, 0.247 \mathrm{mmol}, 53 \% . \quad{ }^{1} \mathrm{H} N M R\left(\mathrm{C}_{6} \mathrm{D}_{6}\right): \delta 7.35(\mathrm{~m}, 2 \mathrm{H}, \mathrm{Ph}), 7.16(\mathrm{~m}$, 1H, Ph), 7.08 (m, 2H, Ph), 1.96 (s, 4H, C( $\left.\left.\mathrm{CH}_{2}\right)_{2}\right), 1.35$ (s, 30H, $\left.\mathrm{C}_{5} \mathrm{Me}_{5}\right)$.

\section{1-3. Dynamic motion in 3}

Although ${ }^{1} \mathrm{H}$ NMR spectrum of $\mathbf{3}$ showed four inequivalent allenic proton resonances that did not show any averaging over the temperature range of $25 \sim 50{ }^{\circ} \mathrm{C}$, spin saturation transfer (SST) was detected for the allenic protons, indicating the presence of a dynamic process.

The allenic signals labeled $\mathrm{H}^{\mathrm{A}} \sim \mathrm{H}^{\mathrm{D}}$ can be assigned as shown below based on their splitting patterns and with the aid of 2D NMR spectroscopy, although the orientation of the $\mathrm{CH}^{\mathrm{A}} \mathrm{H}^{\mathrm{B}}$ and $\mathrm{CH}^{\mathrm{C}} \mathrm{H}^{\mathrm{D}}$ units relative to the phenylimido ligand could not be determined.

When $\mathrm{H}^{\mathrm{A}}$ was irradiated, the intensity of the signal $\mathrm{H}^{\mathrm{D}}$ decreased significantly (Figure $\mathrm{S} 1$ shown below). Likewise, irradiation of $\mathrm{H}^{\mathrm{B}}$ caused the decrease in the intensity of $\mathrm{H}^{\mathrm{C}}$. These results indicate that there is a fluxional process in which the protons $\mathrm{H}^{\mathrm{A}}$ and $\mathrm{H}^{\mathrm{D}}$ mutually exchange their sites, so do protons $\mathrm{H}^{\mathrm{B}}$ and $\mathrm{H}^{\mathrm{C}}$, at a rate that is slower than the NMR time scale. 


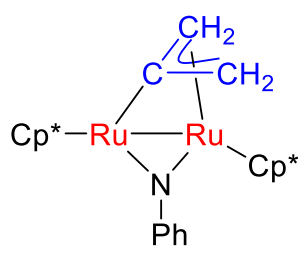

3
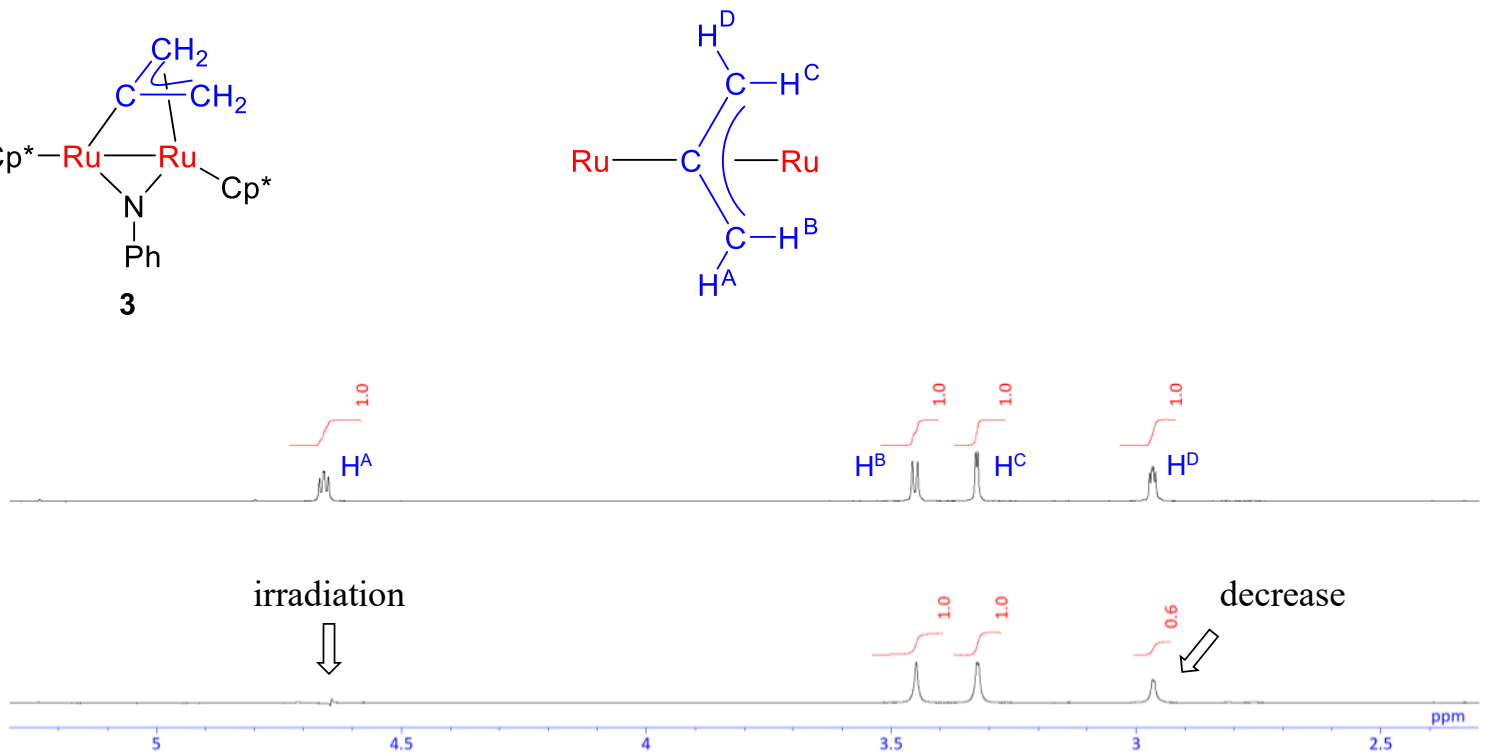

Figure S1. Allenic proton region of the ${ }^{1} \mathrm{H}$ NMR spectrum of 3 in $\mathrm{C}_{6} \mathrm{D}_{6}$ at $25{ }^{\circ} \mathrm{C}$ before (upper) and after (lower) irradiating $\mathrm{H}^{\mathrm{A}}(4.66 \mathrm{ppm})$.

The rate constant $(k)$ of the exchange between $\mathrm{H}^{\mathrm{A}}$ and $\mathrm{H}^{\mathrm{D}}$ was estimated to be $0.39 \mathrm{~s}^{-1}$ at 25 ${ }^{\circ} \mathrm{C}$ using the equation below: ${ }^{4}$

$$
k=\frac{1}{T_{1}}\left(\frac{M_{0}}{M}-1\right)
$$

where $T_{1}=$ the spin-lattice relaxation time for $\mathrm{H}^{\mathrm{D}}$ and $M / M_{0}=$ the net magnetization of $\mathrm{H}^{\mathrm{D}}$ deduced from the relative intensity of the signal for $\mathrm{H}^{\mathrm{D}}$ before and after the irradiation of $\mathrm{H}^{\mathrm{A}}$.

The corresponding Gibbs free energy of activation for this exchange process was calculated to be $19.4 \mathrm{kcal} / \mathrm{mol}$ using the Eyring equation:

$$
\Delta G^{\ddagger}=-R T \ln \left(\frac{h k}{k_{\mathrm{B}} T}\right)
$$

where $R=$ the gas constant, $h=$ the Plank's constant, $k_{\mathrm{B}}=$ the Boltzmann's constant, and $T=$ temperature.

The site exchange between $\mathrm{H}^{\mathrm{A}}$ and $\mathrm{H}^{\mathrm{D}}$ (and between $\mathrm{H}^{\mathrm{B}}$ and $\mathrm{H}^{\mathrm{C}}$ ) in 3 would occur by the energetically degenerate flipping of the allene ligand over the $\mathrm{Ru}_{2} \mathrm{~N}$ plane via the symmetrical transition state TS-flip-3 (Figure S2). DFT calculations for this flipping motion give a Gibbs free energy of activation of $20.4 \mathrm{kcal} / \mathrm{mol}$, which is comparable to the experimental one $(19.4$ $\mathrm{kcal} / \mathrm{mol}$ ) obtained from the SST study. The equal distribution of the ${ }^{13} \mathrm{C}$-labeled $\mathrm{CH}_{2}$ in the synthesis of $3-{ }^{13} \mathrm{C}$ from 2 and $\mathrm{Ph}_{2} \mathrm{~S}^{13} \mathrm{CH}_{2}$ (Scheme 7) can be explained by this flipping motion. 


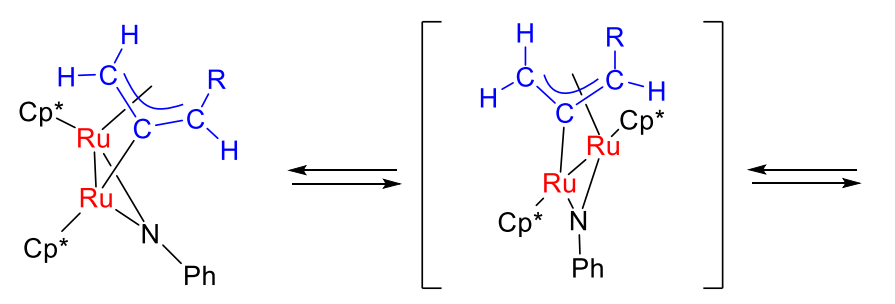

$3(\mathrm{R}=\mathrm{H})$

cis-8 $\left(\mathrm{R}=\mathrm{CH}_{3}\right)$

TS-flip-3 $(\mathrm{R}=\mathrm{H})$

TS-flip-cis-8 $\left(\mathrm{R}=\mathrm{CH}_{3}\right)$

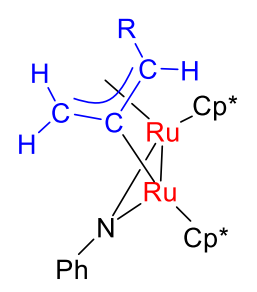

$3(\mathrm{R}=\mathrm{H})$

cis-8' $\left(\mathrm{R}=\mathrm{CH}_{3}\right)$

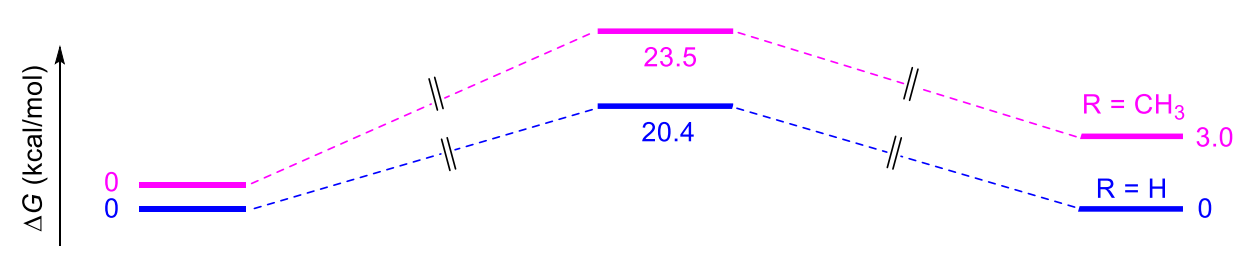

Figure S2. Flipping of allene ligands in $\mathbf{3}$ and cis-8.

We also calculated flipping of the methylallene ligand in $c i s-\mathbf{8}$ which gave the isomer $c i s-\mathbf{8}$, (Figure S2). The calculated Gibbs free energy difference between cis-8 and cis-8' (3.0 $\mathrm{kcal} / \mathrm{mol}$ ) indicates that the equilibrium lies far to the left (cis-8 side).

\section{1-4. Liberation of hydrocarbons}

(a) Hydrogenation of 5

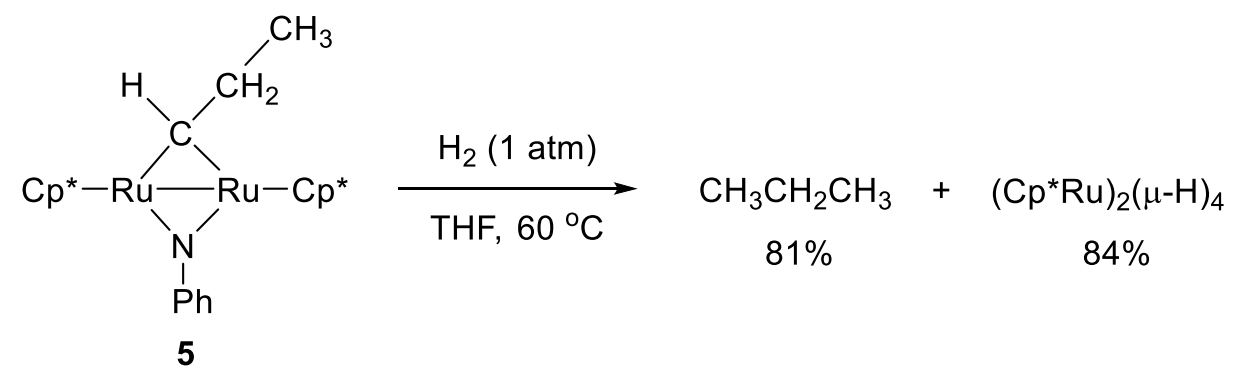

A solution of 5 (73 mg, $0.12 \mathrm{mmol})$ and 1,2-diphenylethane (18 mg, $0.10 \mathrm{mmol}$, internal standard) in THF $(10 \mathrm{~mL})$ was placed in a glass tube (ca. $80 \mathrm{~mL}$ inner volume) equipped with a J-Young right-angle valve. The solution was frozen in a liquid nitrogen, and the glass tube was evacuated with a vacuum pump and sealed. After the solution was thawed, the tube was filled with $\mathrm{H}_{2}(1 \mathrm{~atm})$, and then ethane $(1.5 \mathrm{~mL}$, internal standard) was added by a gas-tight syringe through the side-arm capped with a rubber septum. After the valve was closed, the solution was stirred at $60{ }^{\circ} \mathrm{C}$ for $38 \mathrm{~h}$. The glass tube was then cooled to room temperature, and $0.5 \mathrm{~mL}$ of the headspace gas was taken for GC analysis, which showed the formation of propane in $81 \%$ yield. Then, $1.0 \mathrm{~mL}$ of the reaction solution was taken and evaporated to dryness. The residual solid was dissolved in $\mathrm{C}_{6} \mathrm{D}_{6}(0.6 \mathrm{~mL})$ and analyzed by ${ }^{1} \mathrm{H}$ NMR spectroscopy, which showed the formation of $\left[(\mathrm{Cp} * \mathrm{Ru})_{2}(\mu-\mathrm{H})_{4}\right]$ in $84 \%$ yield. 


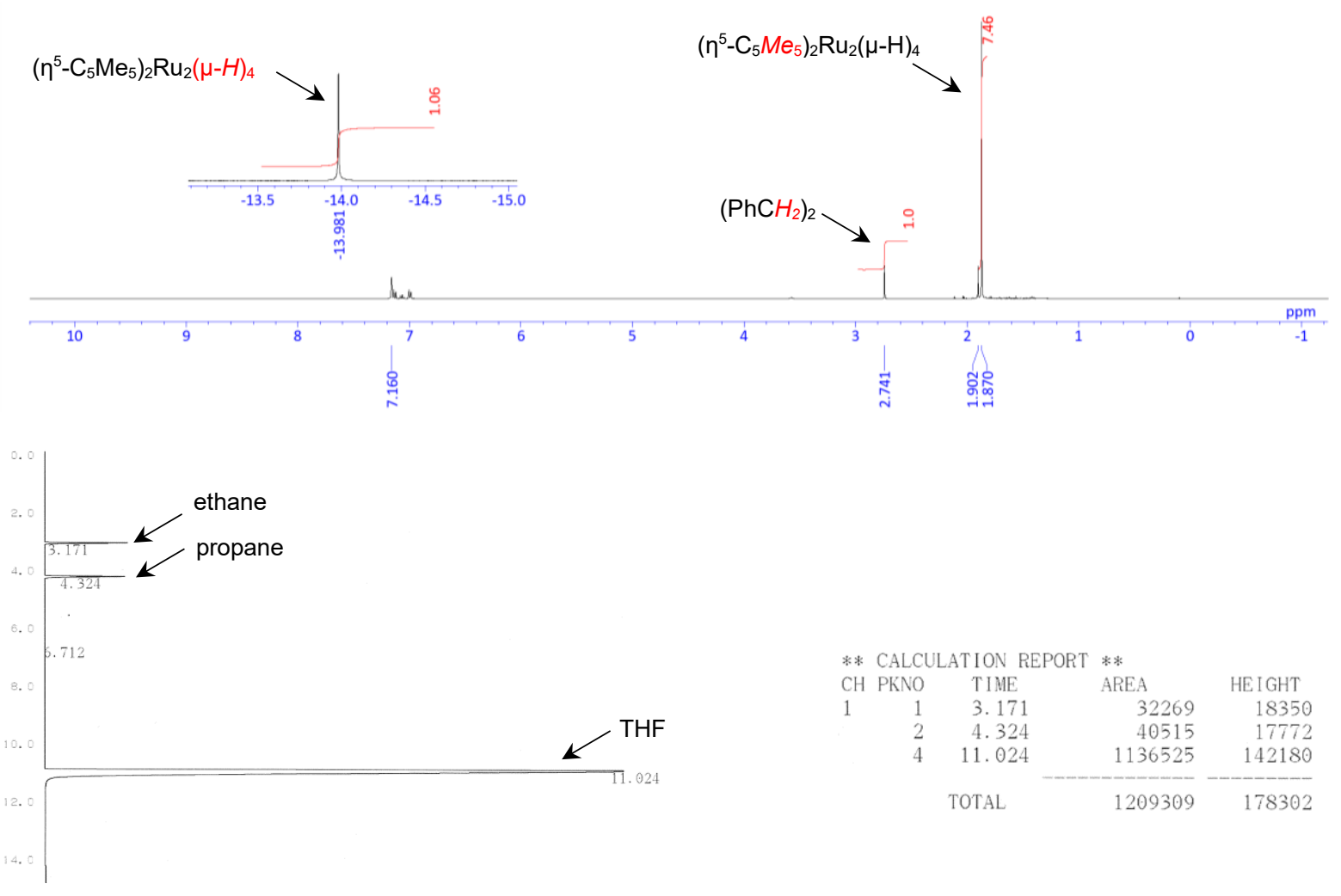

Figure S3. ${ }^{1} \mathrm{H}$ NMR spectrum $\left(\mathrm{C}_{6} \mathrm{D}_{6}, 400 \mathrm{MHz}\right)$ and $\mathrm{GC}$ trace for the hydrogenation of 5 .

(b) Hydrogenation of 7

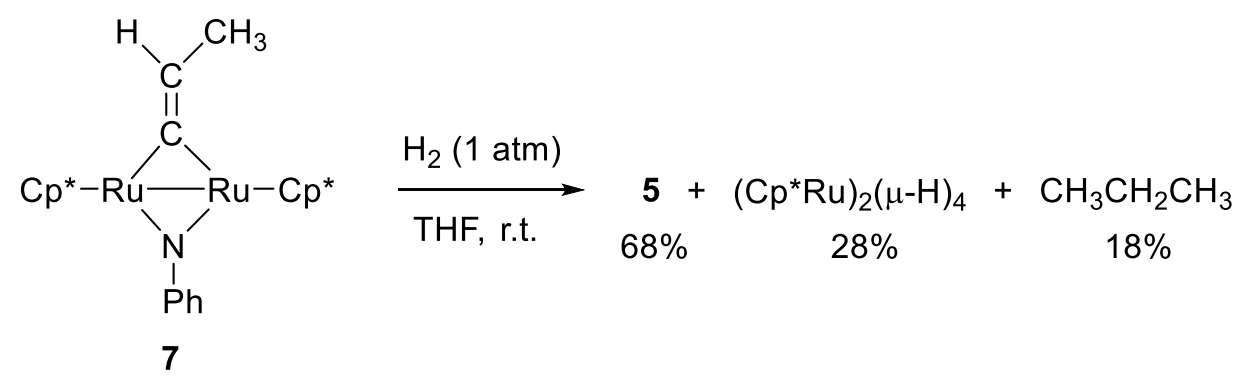

A suspension of $7(73 \mathrm{mg}, 0.16 \mathrm{mmol})$ in THF $(10 \mathrm{~mL})$ in a Schlenk tube was stirred under $\mathrm{H}_{2}(1 \mathrm{~atm})$ atmosphere for $18 \mathrm{~h}$. The mixture gradually became homogeneous, forming a dark red solution. After ethane $(1.5 \mathrm{~mL}$, internal standard) was added through the side-arm capped with a rubber septum, $0.5 \mathrm{~mL}$ of the headspace gas was analyzed by GC, which showed the formation of propane in $18 \%$ yield. After 1,2-diphenylethane (18 mg, internal standard) was added, $0.80 \mathrm{~mL}$ of the reaction solution was taken and evaporated to dryness. ${ }^{1} \mathrm{H}$ NMR analysis of the residual solid dissolved in $\mathrm{C}_{6} \mathrm{D}_{6}(0.6 \mathrm{~mL})$ showed the formation of 5 and $\left[(\mathrm{Cp} * \mathrm{Ru})_{2}(\mu-\mathrm{H})_{4}\right]$ in $68 \%$ and $28 \%$ yield, respectively. 
(c) Hydrogenation of $\mathbf{1 7}$

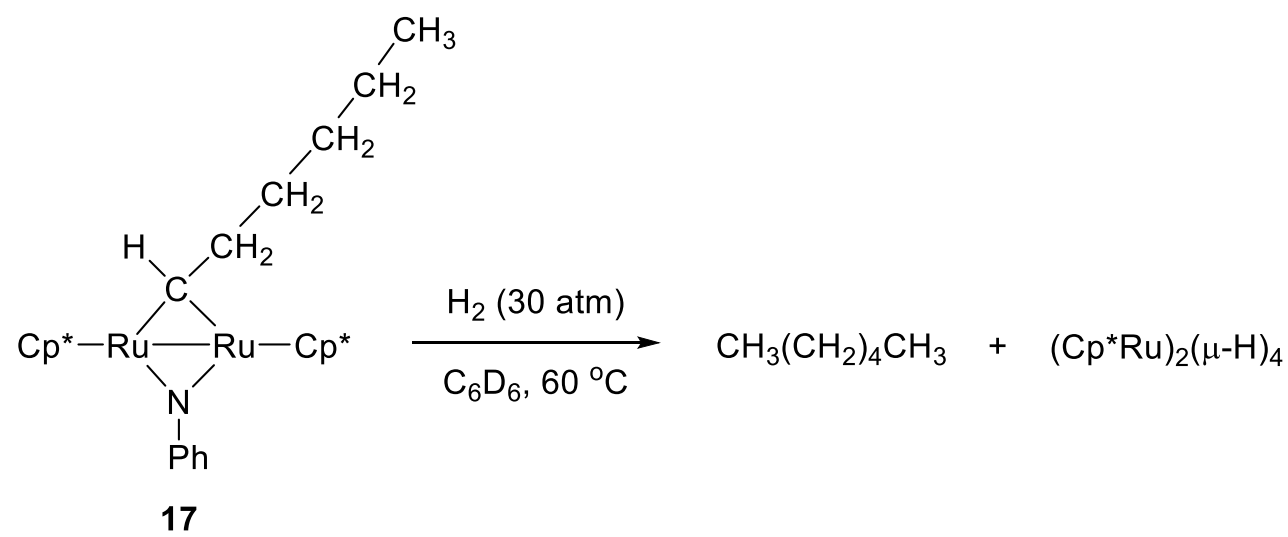

A solution of 17 (30 mg, $0.16 \mathrm{mmol})$ in $\mathrm{C}_{6} \mathrm{D}_{6}(1 \mathrm{~mL})$ was placed in a stainless-steel autoclave and hydrogenated with $\mathrm{H}_{2}(30 \mathrm{~atm})$ at $60{ }^{\circ} \mathrm{C}$ for $12 \mathrm{~h}$. After the autoclave was cooled to room temperature and carefully depressurized, the reaction solution was analyzed by ${ }^{1} \mathrm{H}$ NMR spectroscopy, which showed the formation of $n$-hexane and [(Cp*Ru$\left.)_{2}(\mu-\mathrm{H})_{4}\right]$.

\section{1-5. Attempts to induce thermal isomerization of 3 to 7}

When the allene complex 3 was heated at $90{ }^{\circ} \mathrm{C}$ in toluene for $25 \mathrm{~h}$, a complicated mixture of products was formed with complete consumption of the starting $\mathbf{3}$. The thermolysis of $\mathbf{3}$ at lower temperature $\left(60^{\circ} \mathrm{C}\right.$ and $\left.70{ }^{\circ} \mathrm{C}\right)$ also gave a complicated mixture of products, although the rate of the conversion of $\mathbf{3}$ was much slower (incomplete conversion of $\mathbf{3}$ after 4 days of heating at $70^{\circ} \mathrm{C}$ ). There were no signs of the formation of the vinylidene complex 7 in these experiments. We also attempted the protonation of $\mathbf{3}$ (with HOTf) with an expectation to form the propylidyne [6][OTf]. However, a complicated mixture of products was again formed with complete consumption of $\mathbf{3}$. 


\section{NMR Spectra}

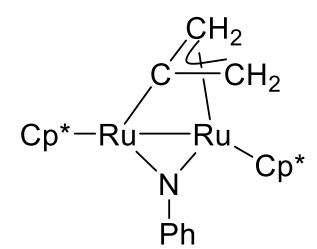

3

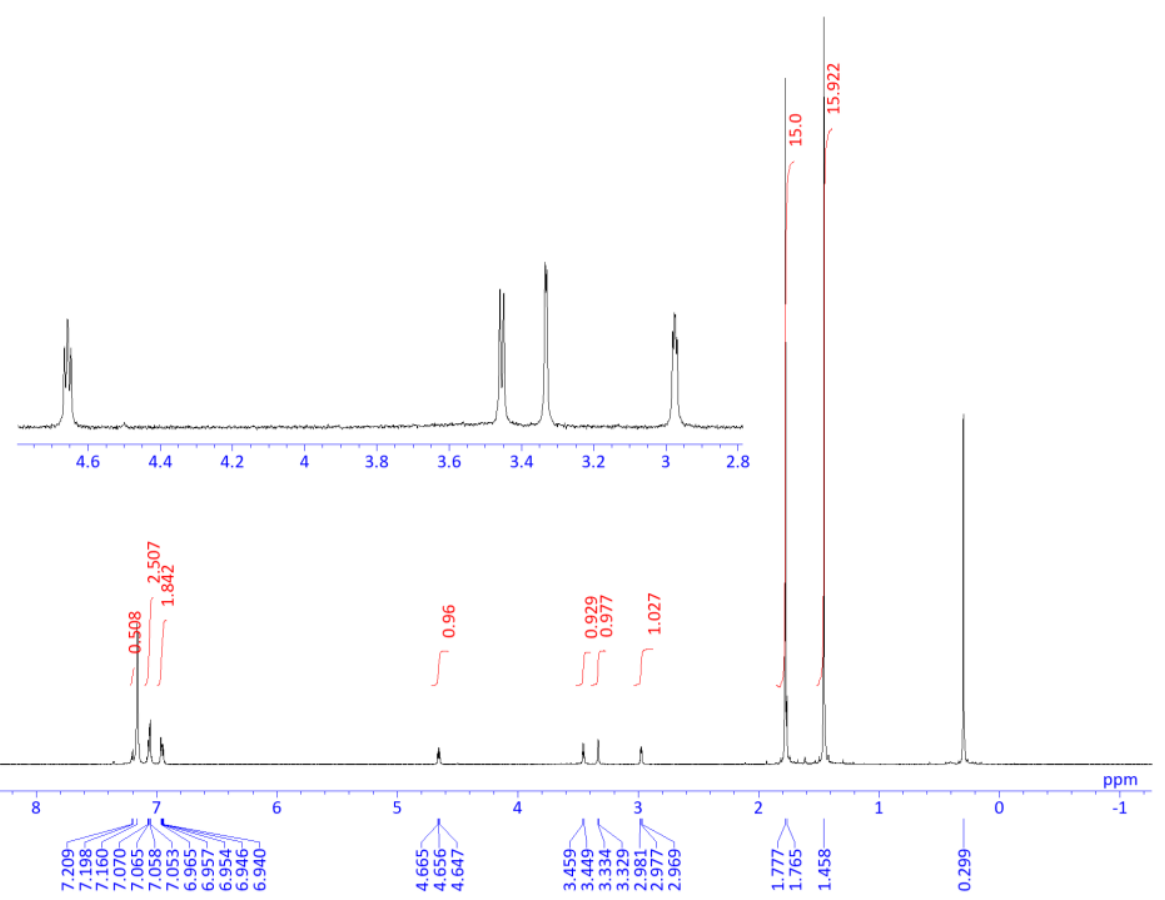

Figure S4. $\quad{ }^{1} \mathrm{H}$ NMR spectrum of $3\left(400 \mathrm{MHz}, \mathrm{C}_{6} \mathrm{D}_{6}\right)$.

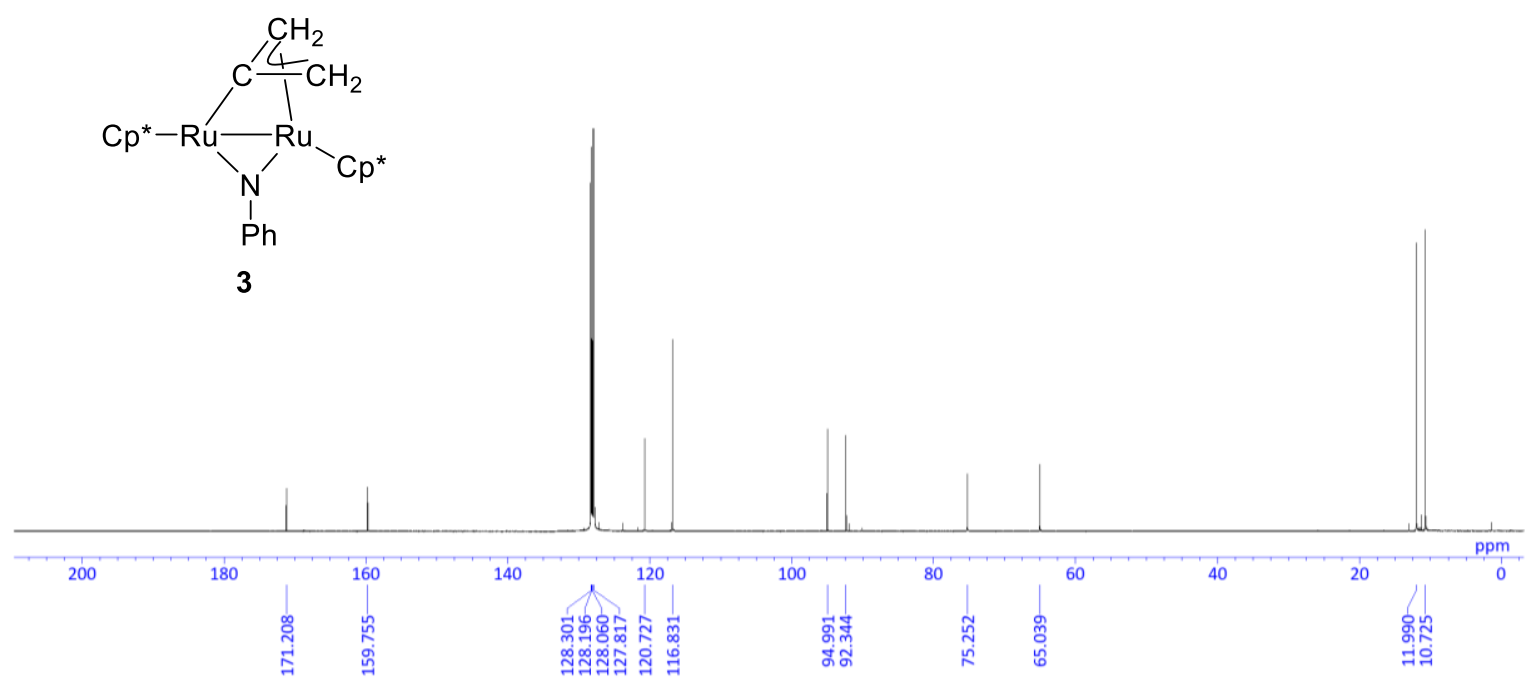

Figure S5. ${ }^{13} \mathrm{C}\left\{{ }^{1} \mathrm{H}\right\}$ NMR spectrum of $3\left(101 \mathrm{MHz}, \mathrm{C}_{6} \mathrm{D}_{6}\right)$. 


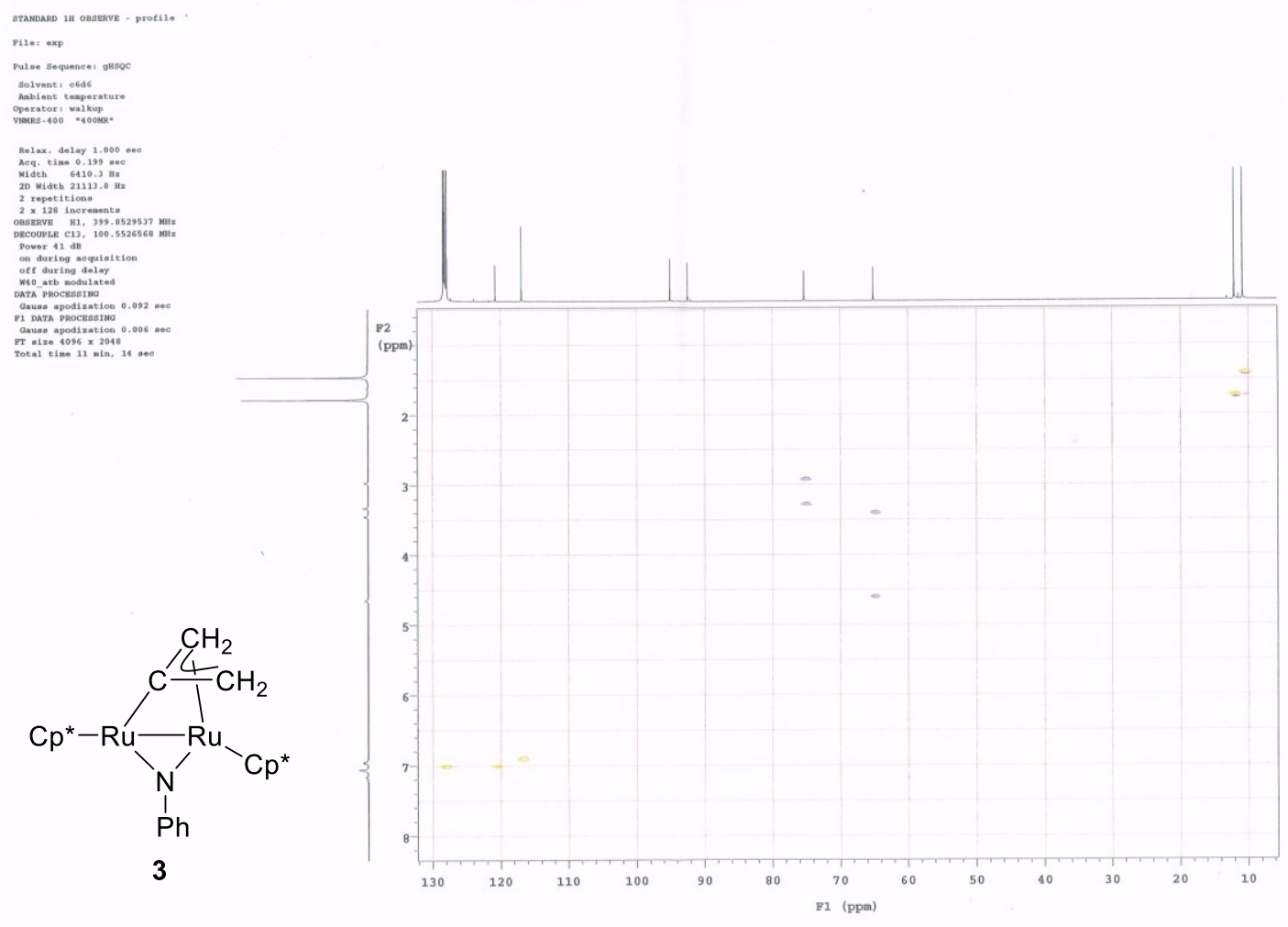

Figure S6. $\quad{ }^{1} \mathrm{H}-{ }^{13} \mathrm{C}$ HSQC spectrum of $3\left(\mathrm{C}_{6} \mathrm{D}_{6}\right)$.
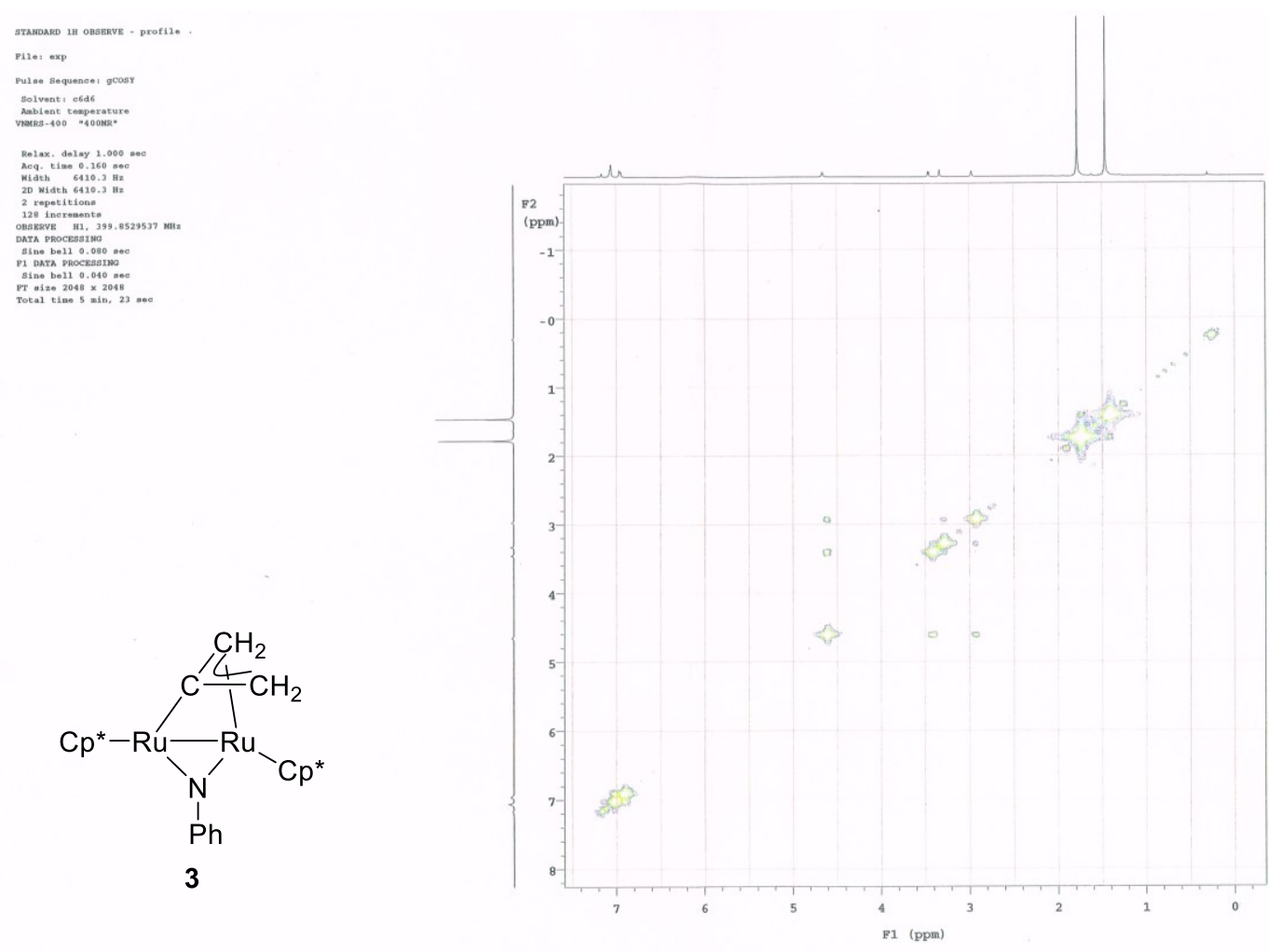

Figure S7. $\quad{ }^{1} \mathrm{H}-{ }^{1} \mathrm{H}$ COSY spectrum of $3\left(\mathrm{C}_{6} \mathrm{D}_{6}\right)$. 


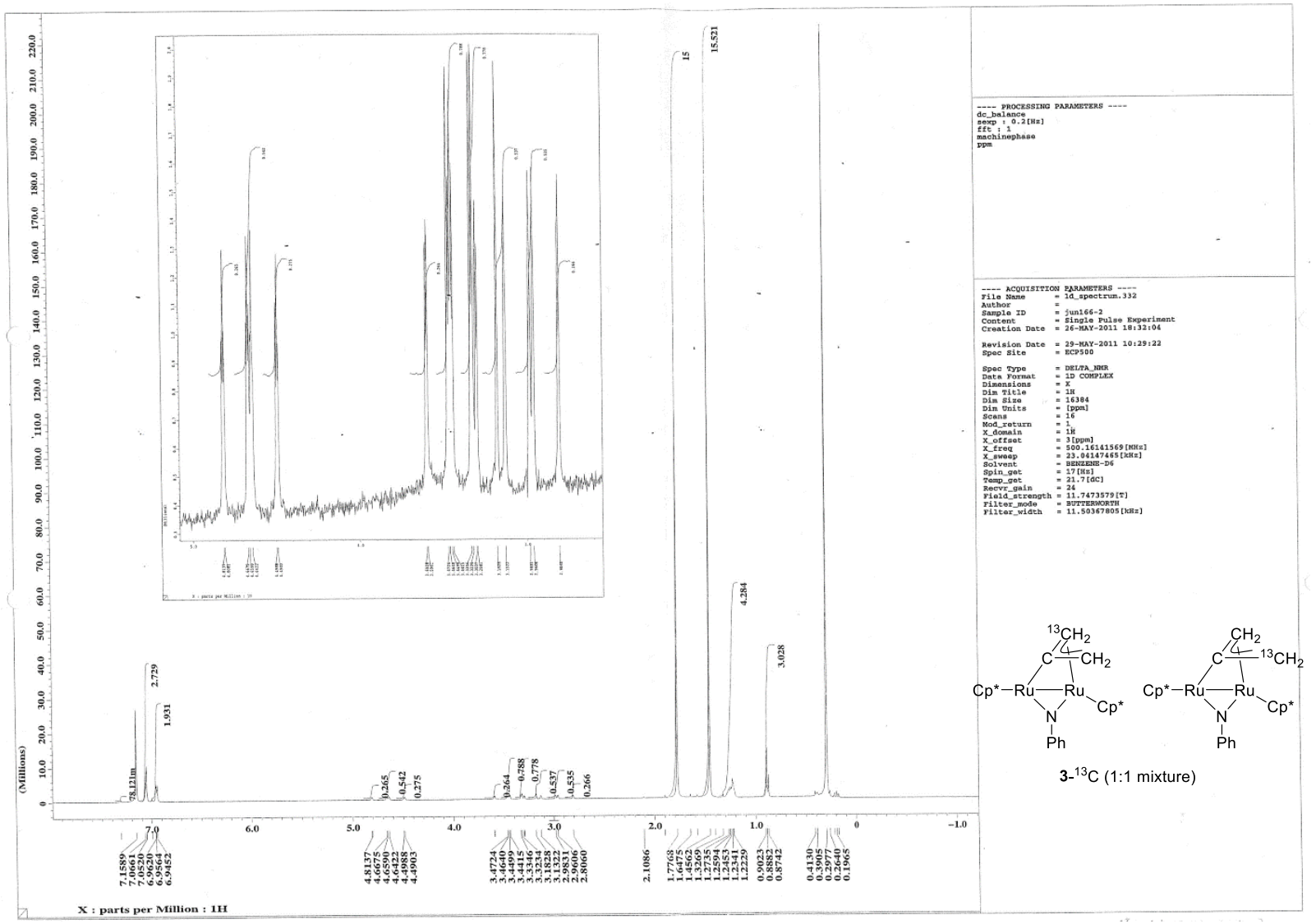

Figure S8. $\quad{ }^{1} \mathrm{H}$ NMR spectrum of $3-{ }^{13} \mathrm{C}\left(500 \mathrm{MHz}, \mathrm{C}_{6} \mathrm{D}_{6}\right)$.

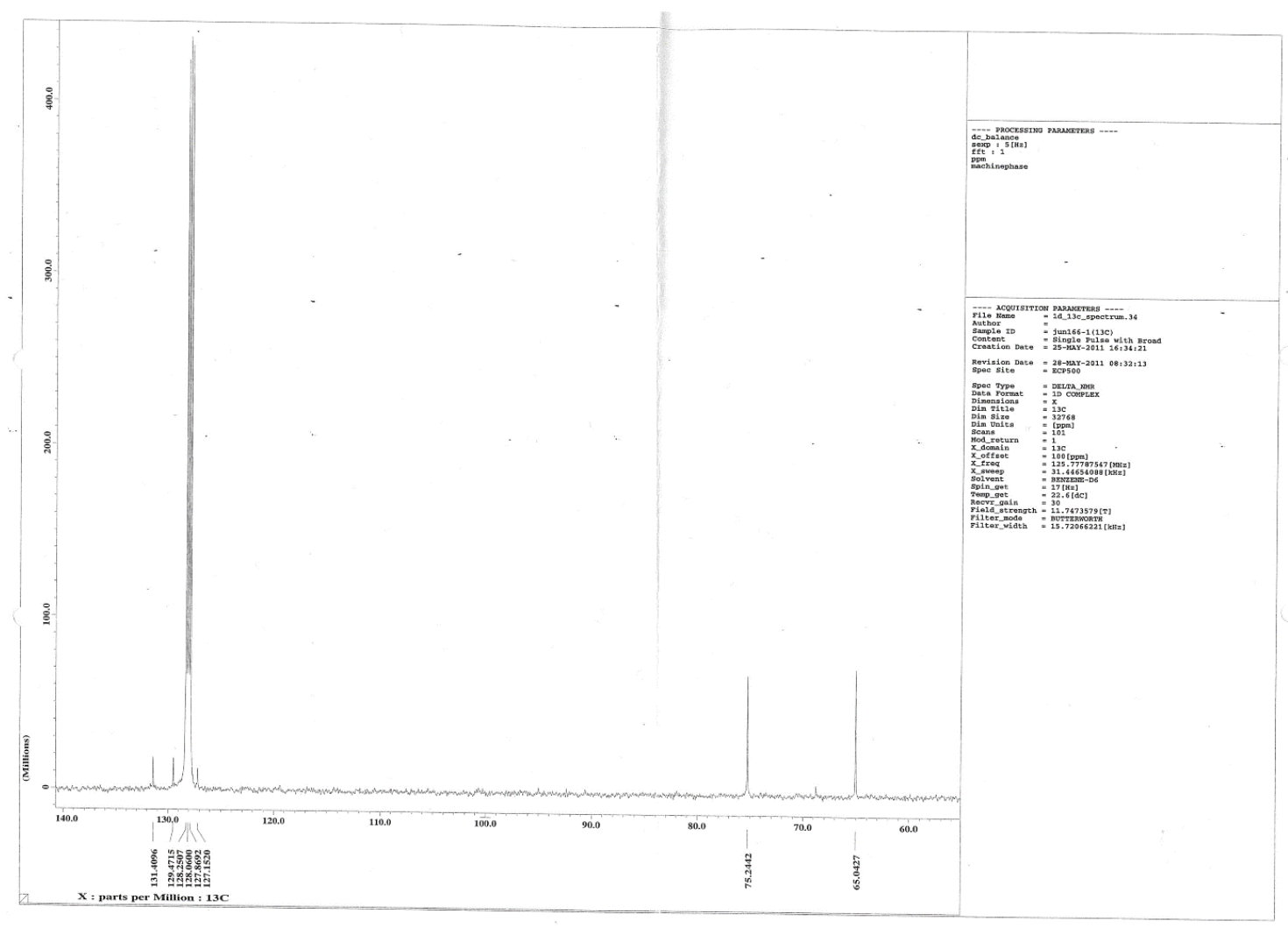

Figure S9. ${ }^{13} \mathrm{C}\left\{{ }^{1} \mathrm{H}\right\}$ NMR spectrum of $3-{ }^{13} \mathrm{C}\left(126 \mathrm{MHz}, \mathrm{C}_{6} \mathrm{D}_{6}\right)$. 

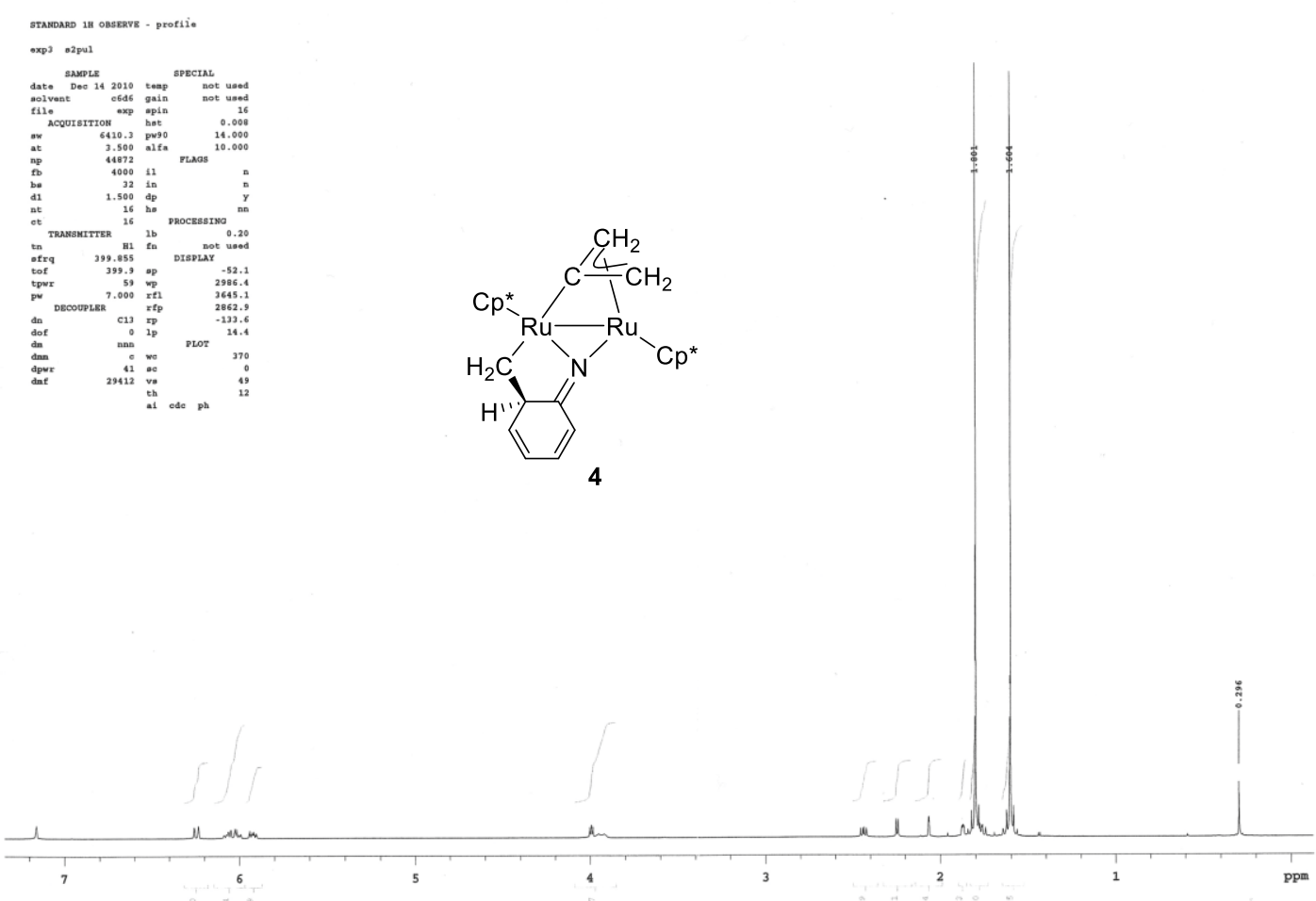

Figure S10. ${ }^{1} \mathrm{H}$ NMR spectrum of $4\left(400 \mathrm{MHz}, \mathrm{C}_{6} \mathrm{D}_{6}\right)$.

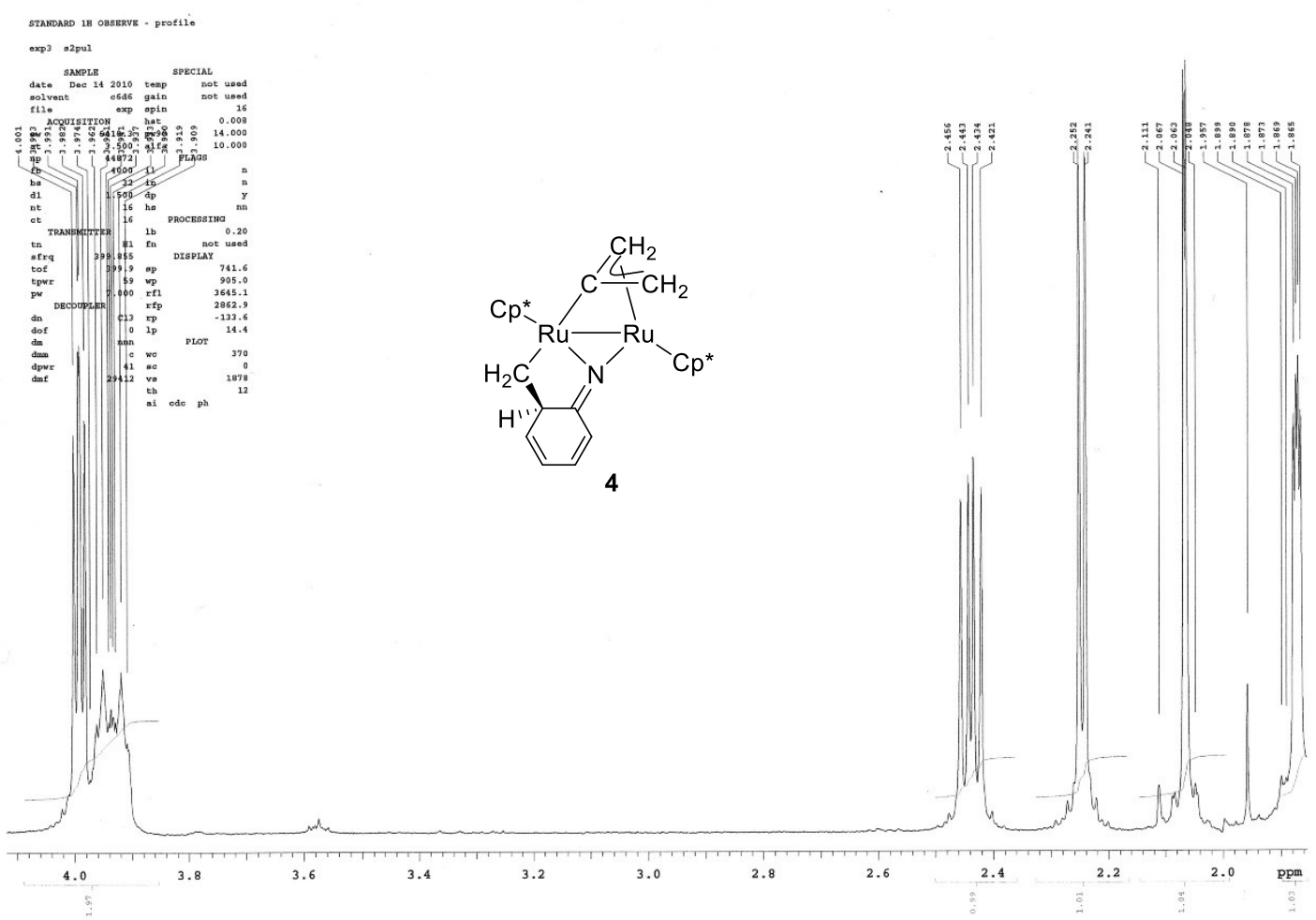

Figure S10 (expansion 1). $\quad{ }^{1} \mathrm{H}$ NMR spectrum of $4\left(400 \mathrm{MHz}, \mathrm{C}_{6} \mathrm{D}_{6}\right)$. 


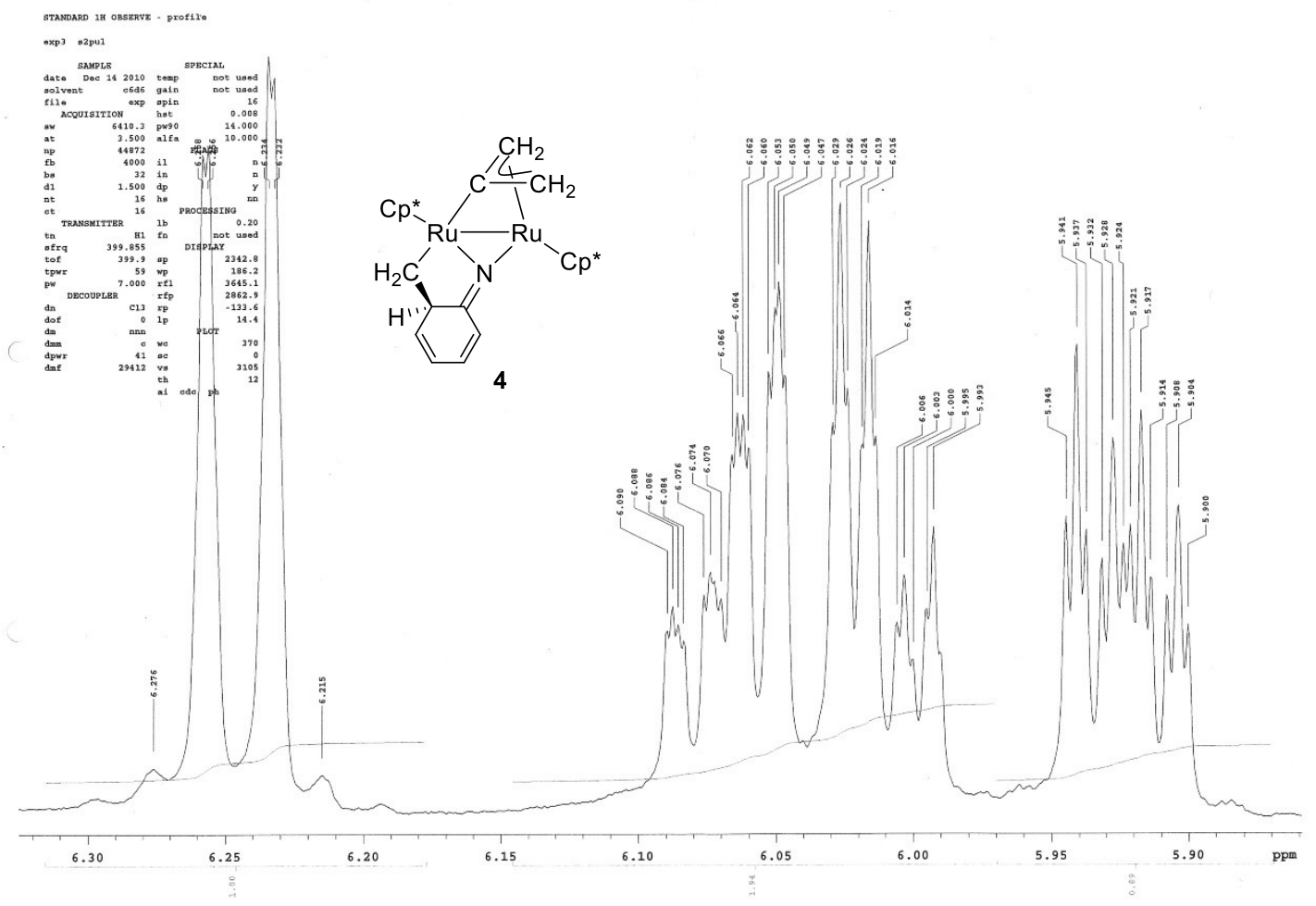

Figure S10 (expansion 2). $\quad{ }^{1} \mathrm{H}$ NMR spectrum of $4\left(400 \mathrm{MHz}, \mathrm{C}_{6} \mathrm{D}_{6}\right)$.

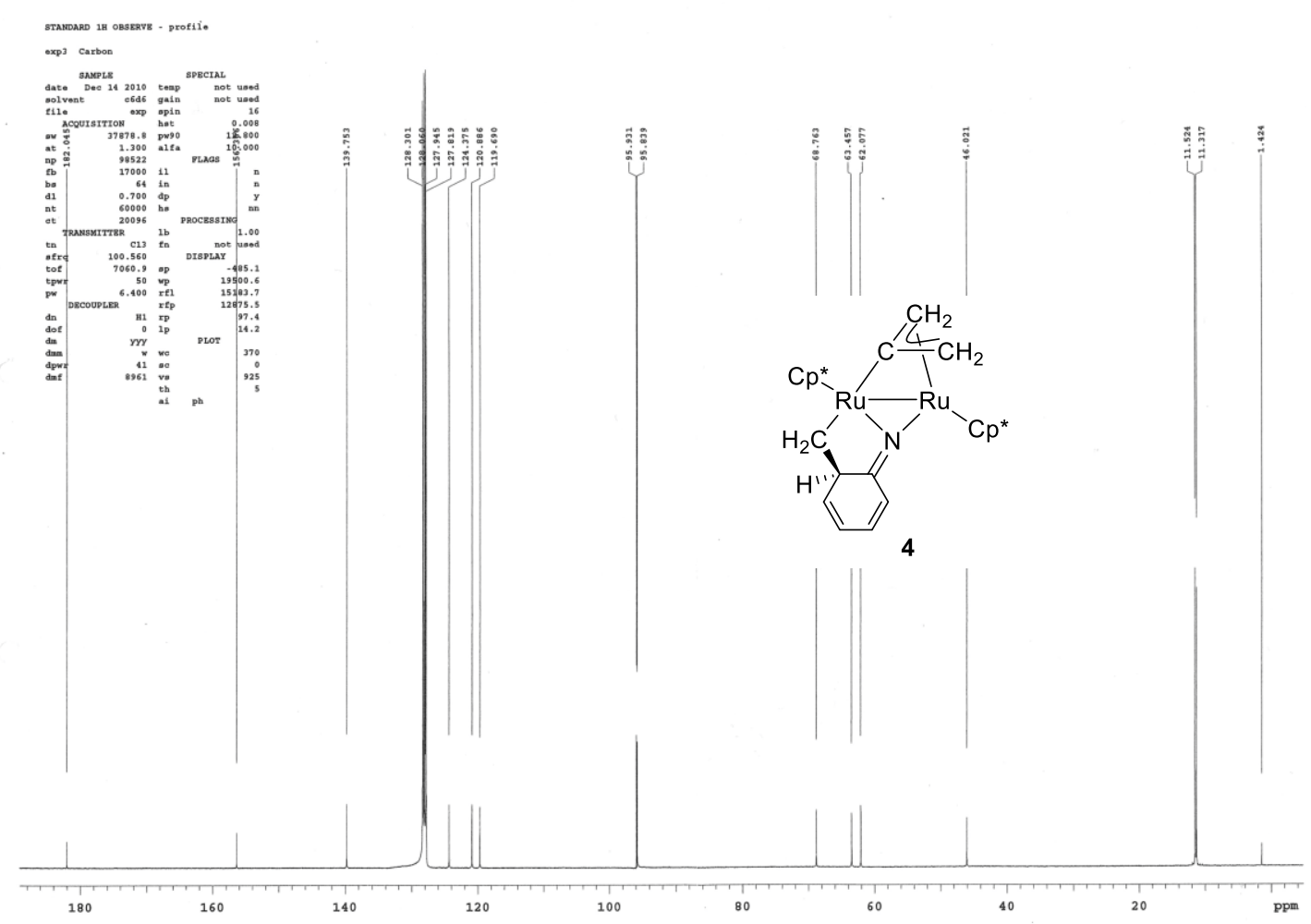

Figure S11. ${ }^{13} \mathrm{C}\left\{{ }^{1} \mathrm{H}\right\}$ NMR spectrum of $4\left(101 \mathrm{MHz}, \mathrm{C}_{6} \mathrm{D}_{6}\right)$. 


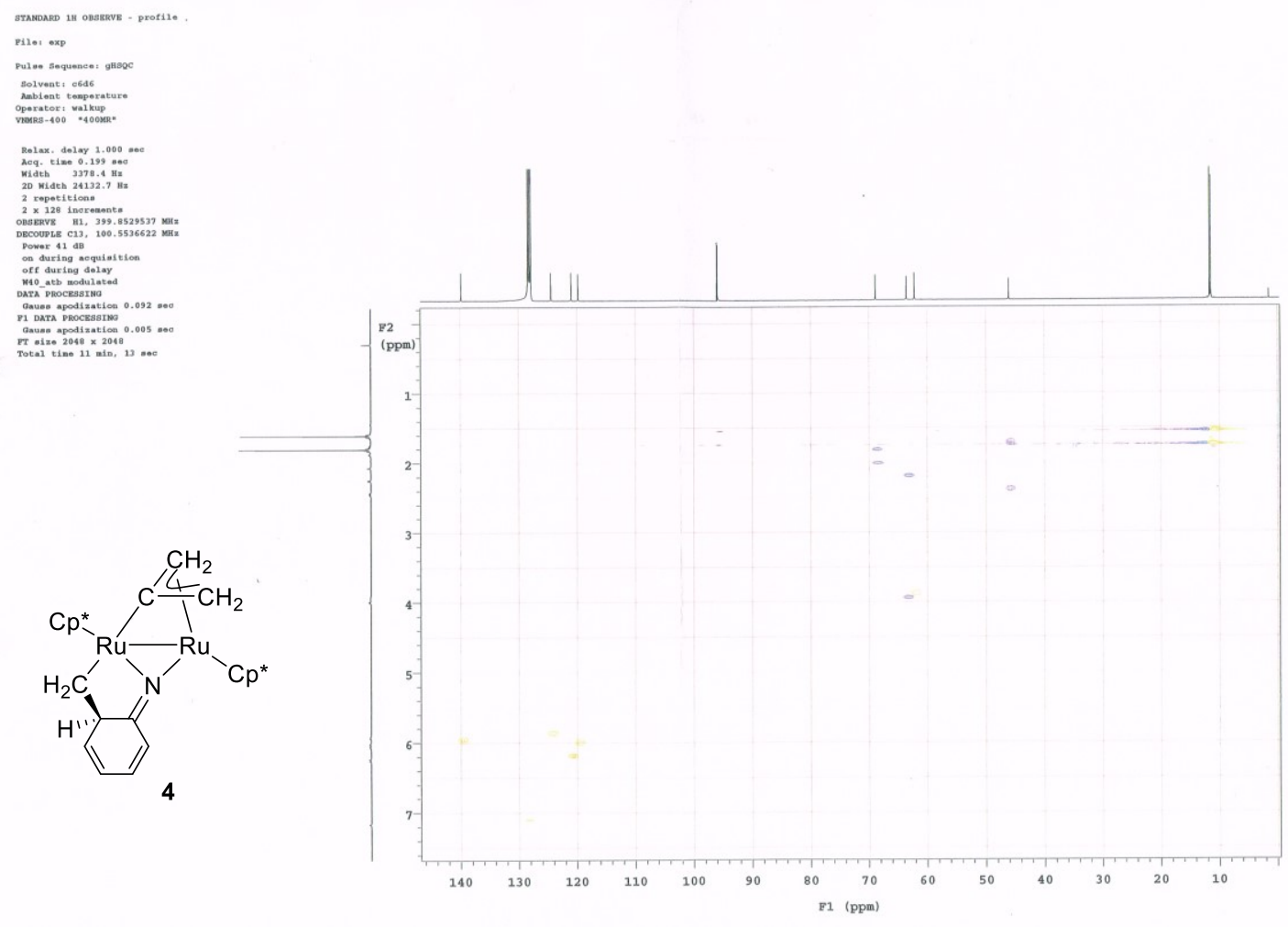

Figure S12. $\quad{ }^{1} \mathrm{H}-{ }^{13} \mathrm{C}$ HSQC spectrum of $4\left(\mathrm{C}_{6} \mathrm{D}_{6}\right)$.
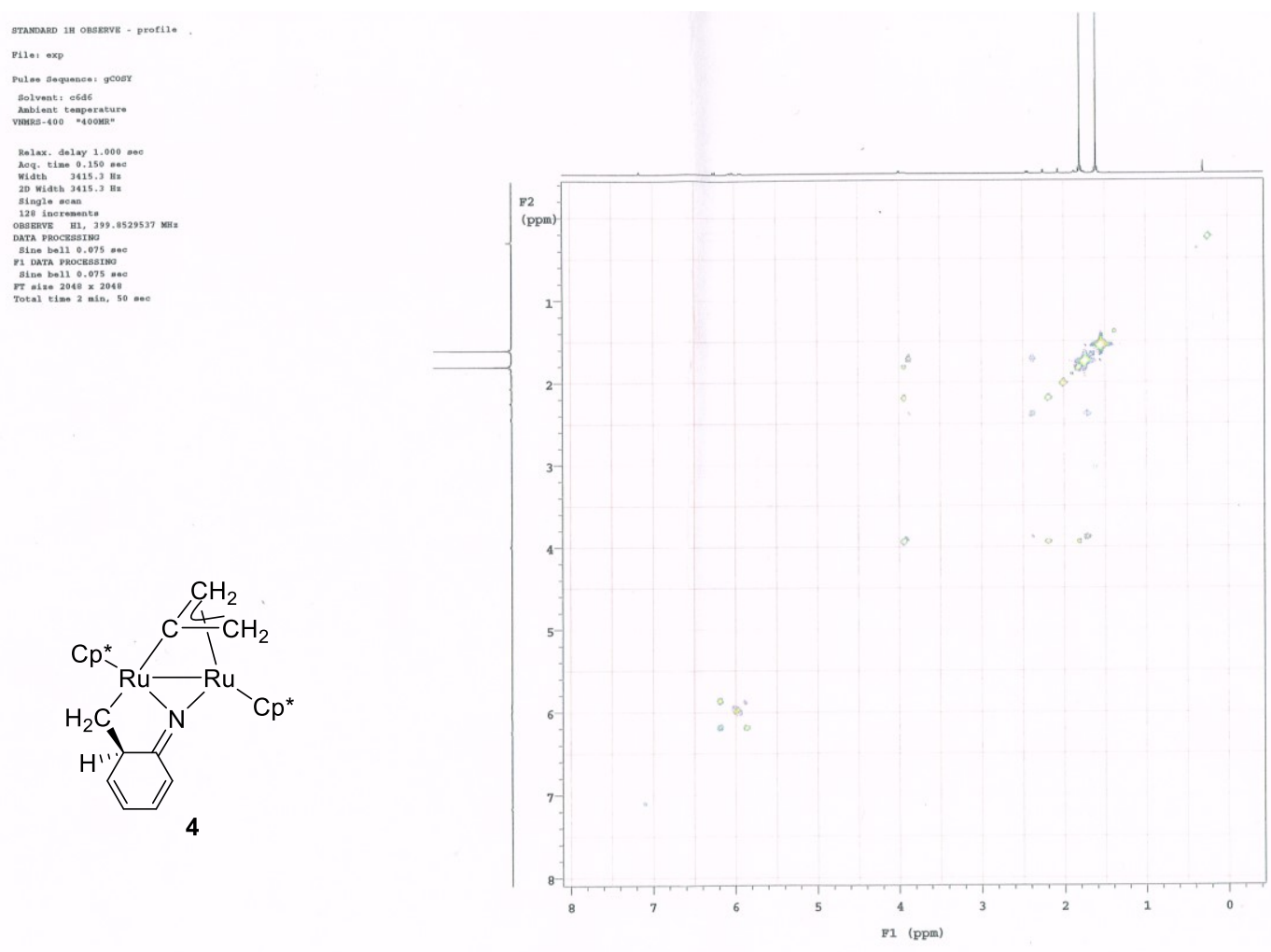

Figure S13. ${ }^{1} \mathrm{H}-{ }^{1} \mathrm{H}$ COSY spectrum of $4\left(\mathrm{C}_{6} \mathrm{D}_{6}\right)$. 

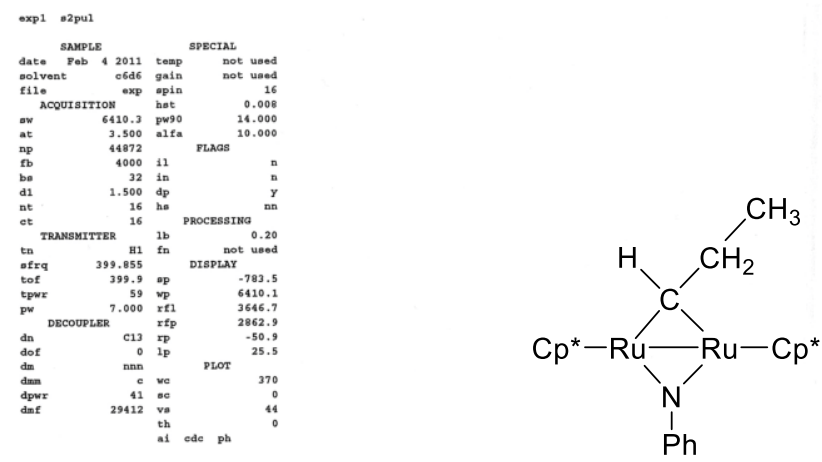

5

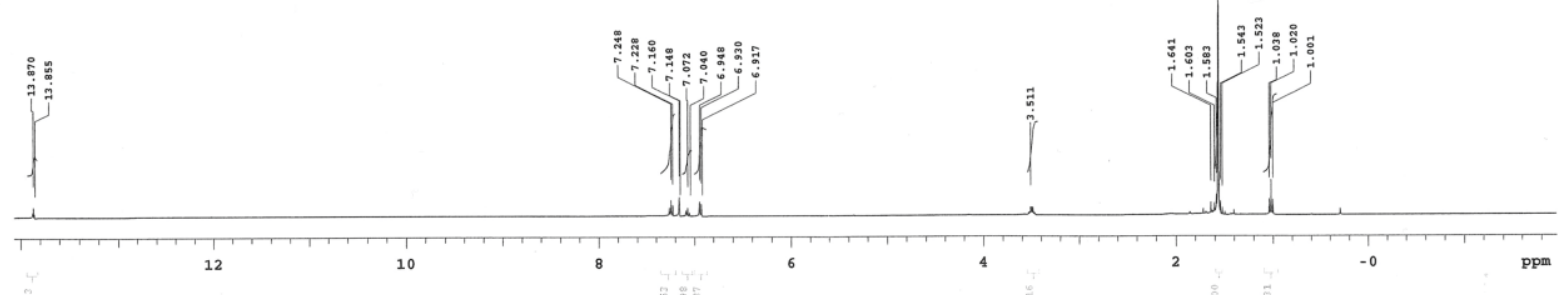

Figure S14. $\quad{ }^{1} \mathrm{H}$ NMR spectrum of $5\left(400 \mathrm{MHz}, \mathrm{C}_{6} \mathrm{D}_{6}\right)$.
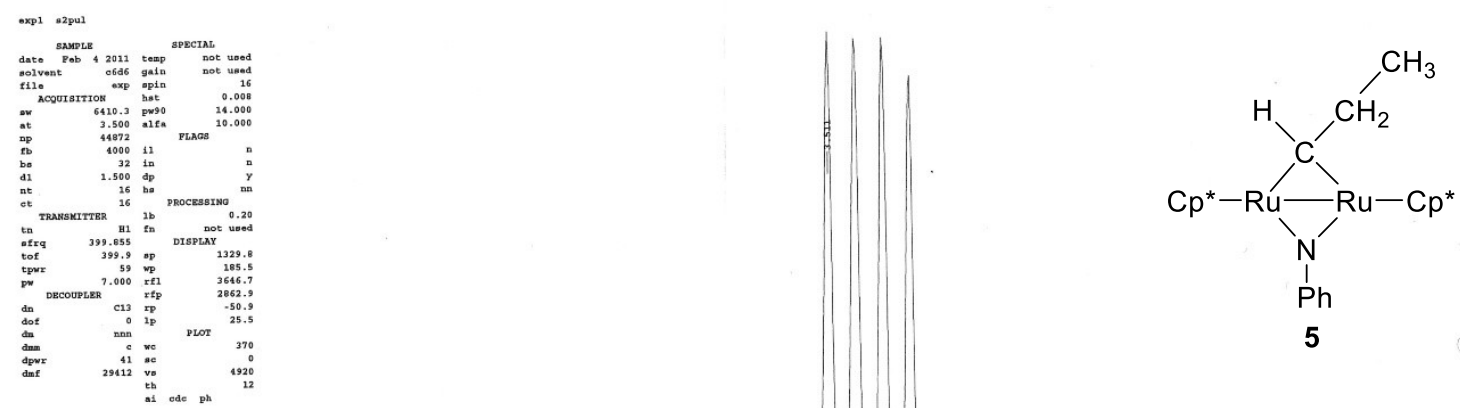

Figure S14 (expansion 1). $\quad{ }^{1} \mathrm{H}$ NMR spectrum of 5 (400 MHz, $\left.\mathrm{C}_{6} \mathrm{D}_{6}\right)$. 


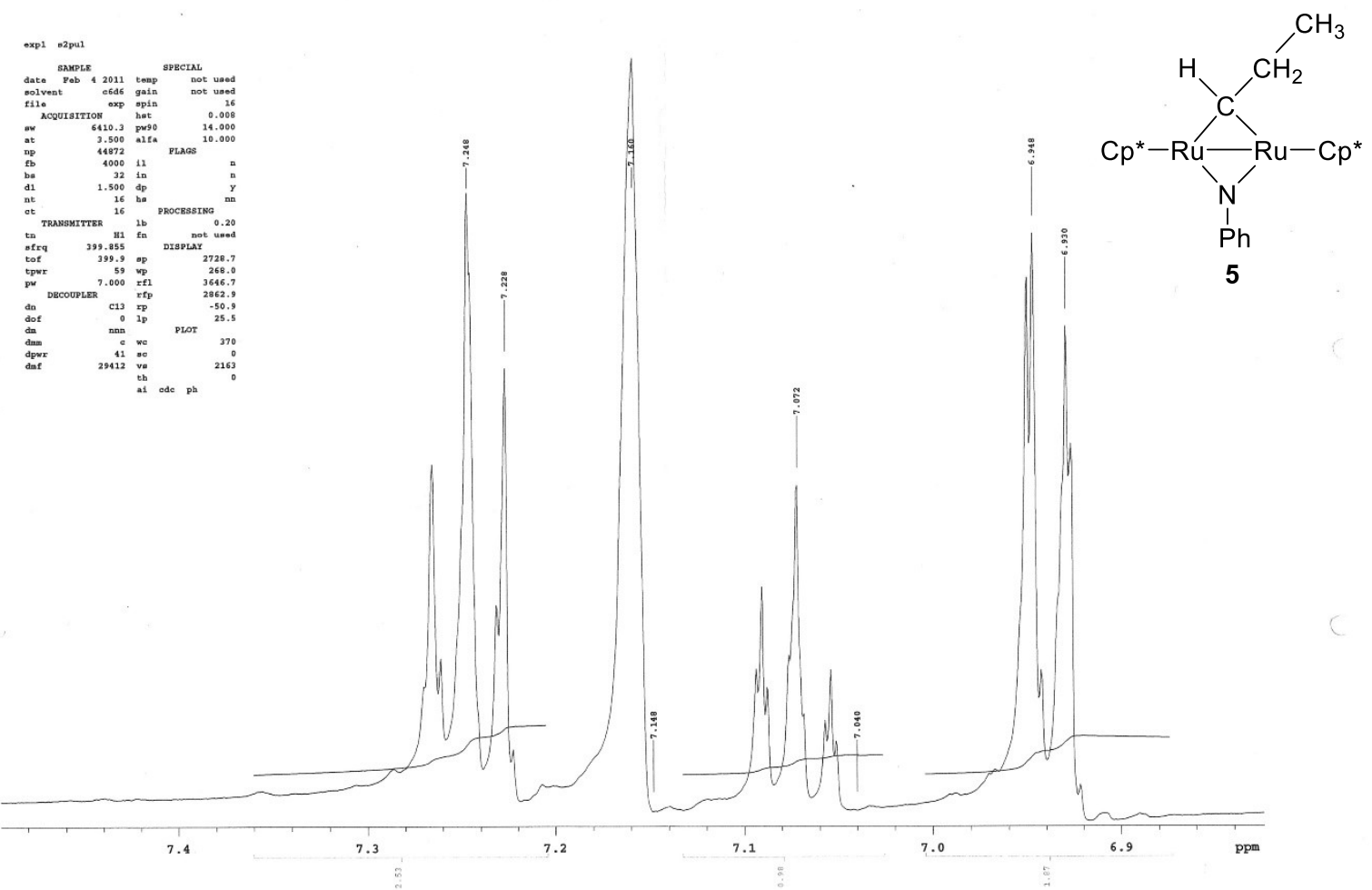

Figure S14 (expansion 2). ${ }^{1} \mathrm{H}$ NMR spectrum of $5\left(400 \mathrm{MHz}, \mathrm{C}_{6} \mathrm{D}_{6}\right)$.

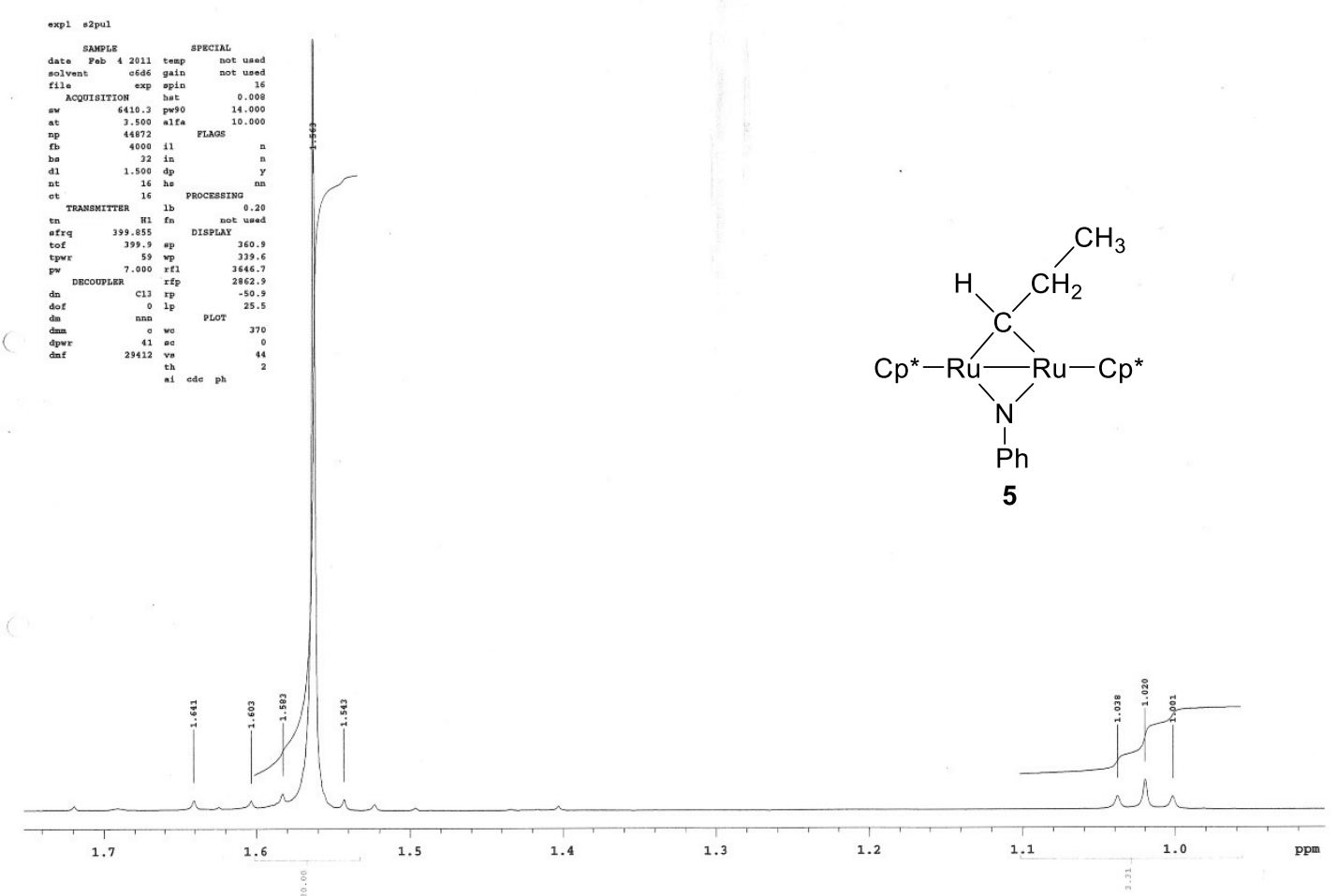

Figure S14 (expansion 3). $\quad{ }^{1} \mathrm{H}$ NMR spectrum of $5\left(400 \mathrm{MHz}, \mathrm{C}_{6} \mathrm{D}_{6}\right)$. 

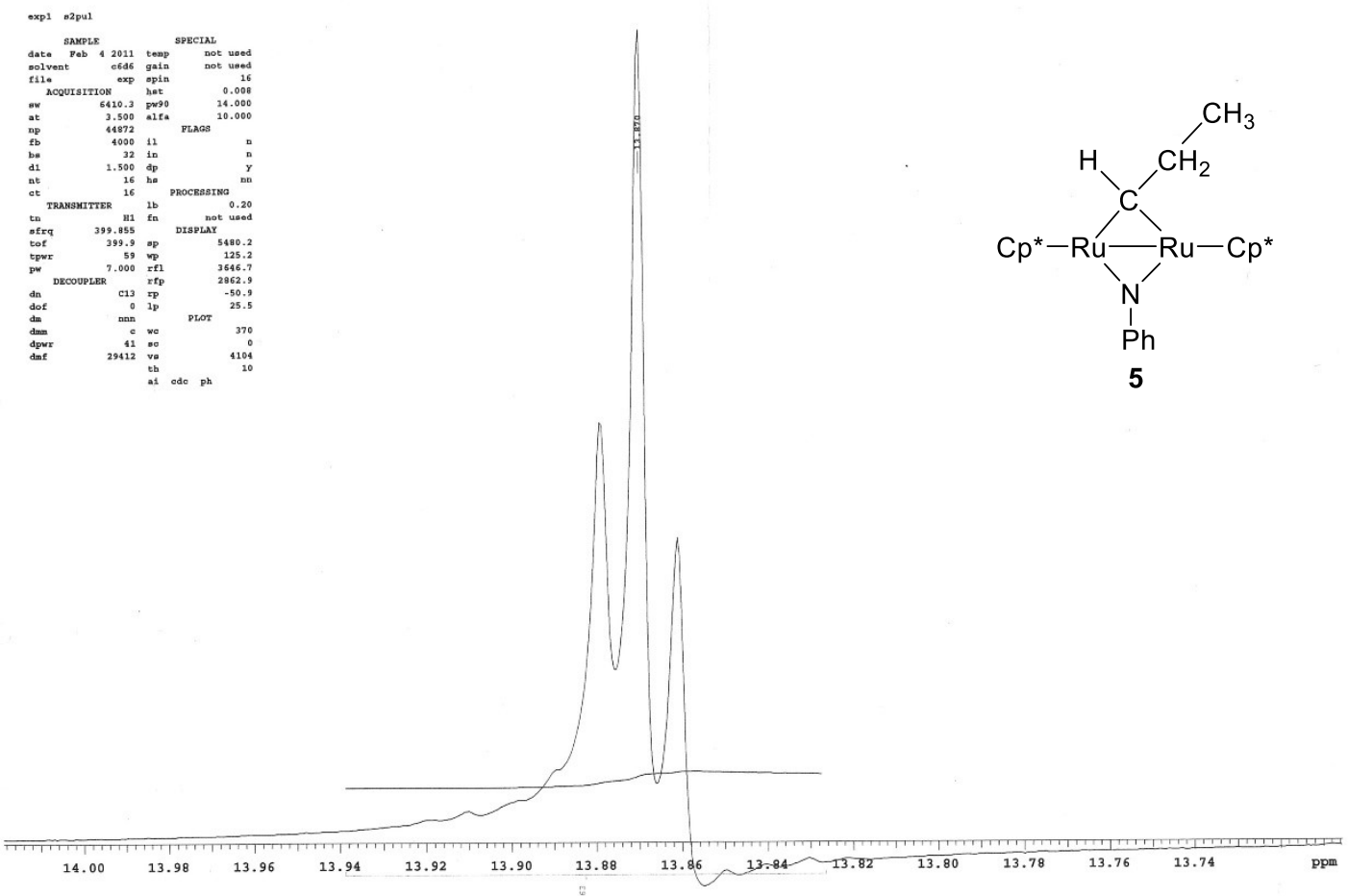

Figure S14 (expansion 4). ${ }^{1} \mathrm{H}$ NMR spectrum of $5\left(400 \mathrm{MHz}, \mathrm{C}_{6} \mathrm{D}_{6}\right)$.
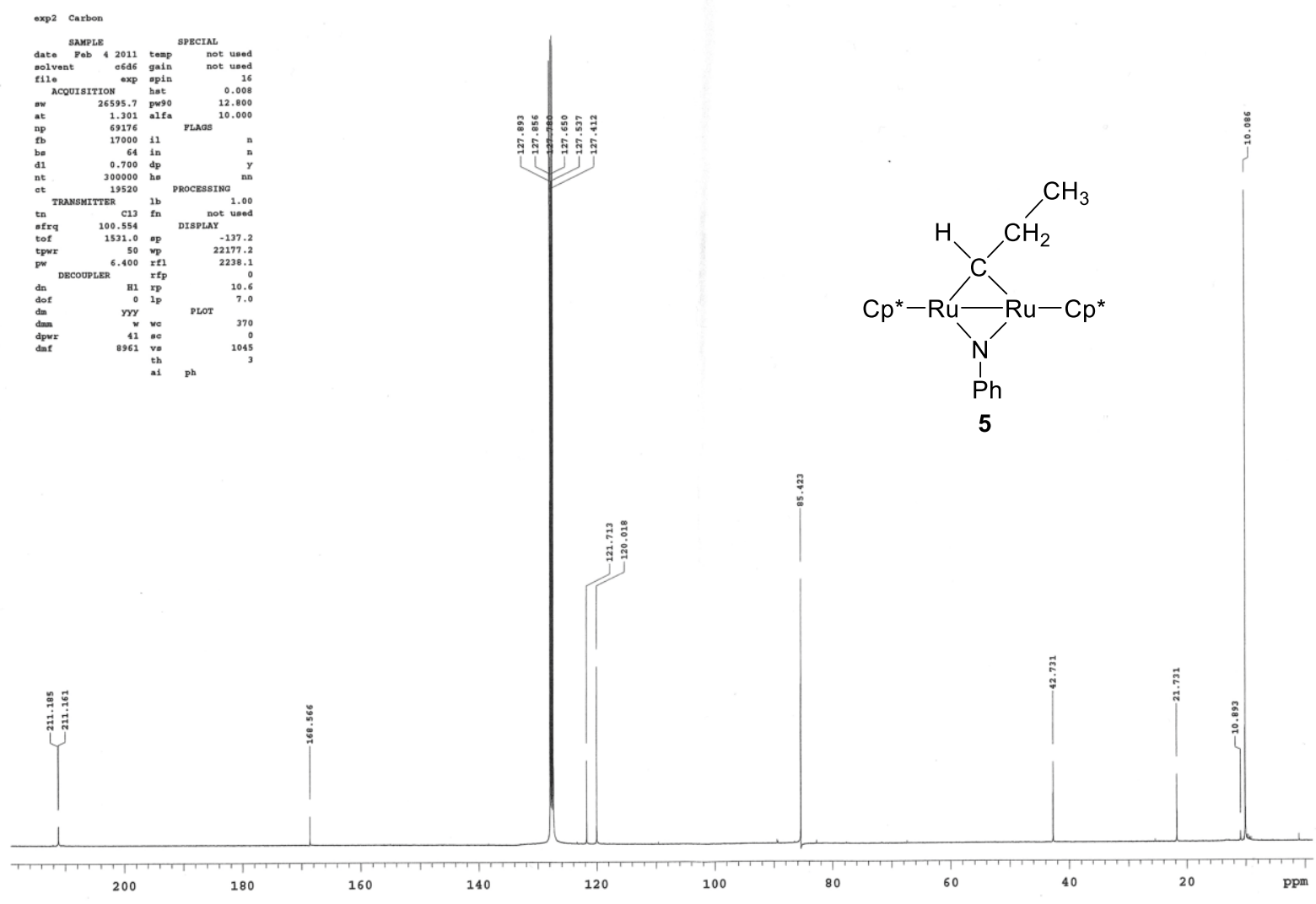

Figure S15. ${ }^{13} \mathrm{C}\left\{{ }^{1} \mathrm{H}\right\}$ NMR spectrum of $5\left(101 \mathrm{MHz}, \mathrm{C}_{6} \mathrm{D}_{6}\right)$. 


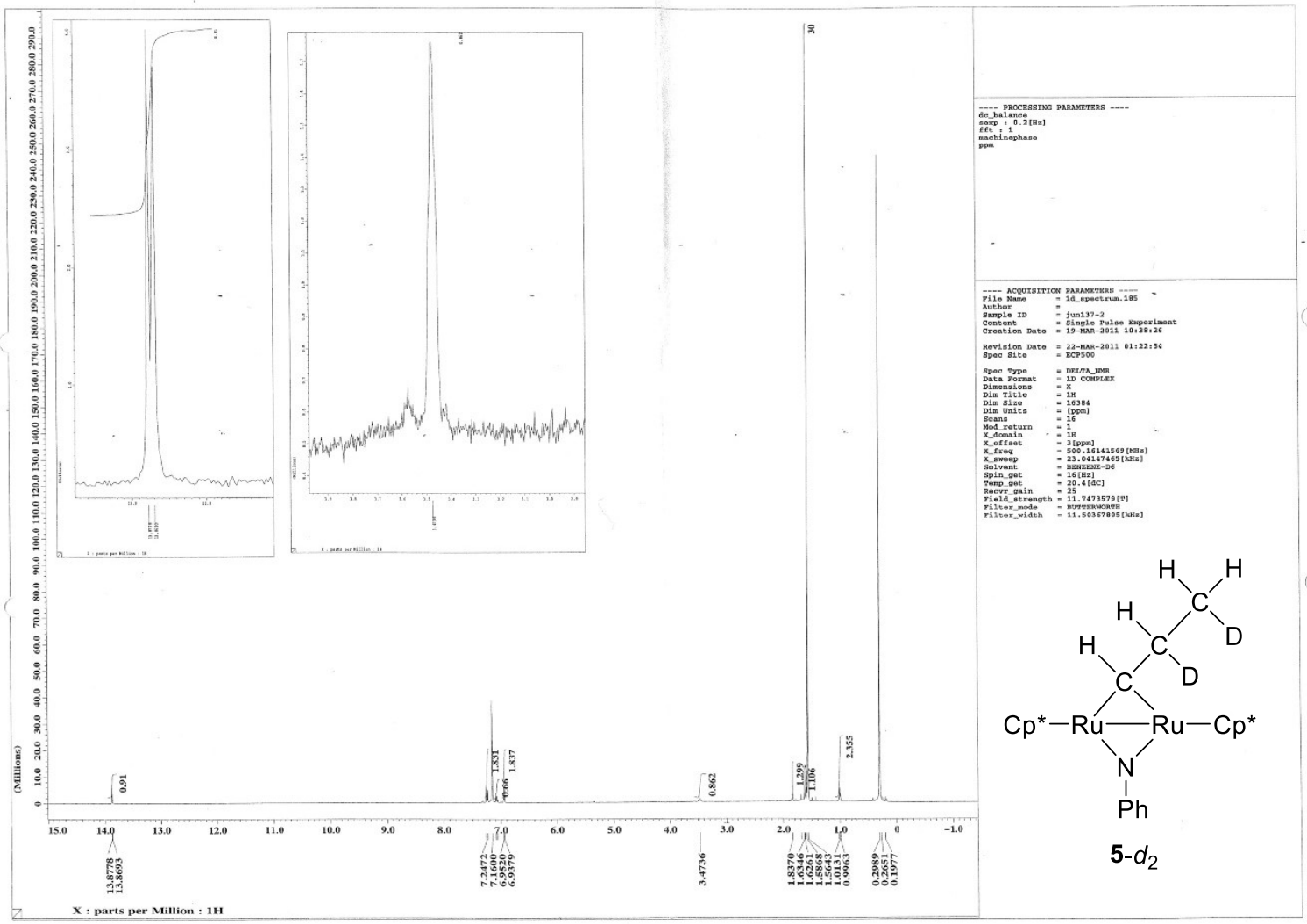

Figure S16. ${ }^{1} \mathrm{H}$ NMR spectrum of 5- $d_{2}\left(500 \mathrm{MHz}, \mathrm{C}_{6} \mathrm{D}_{6}\right)$.

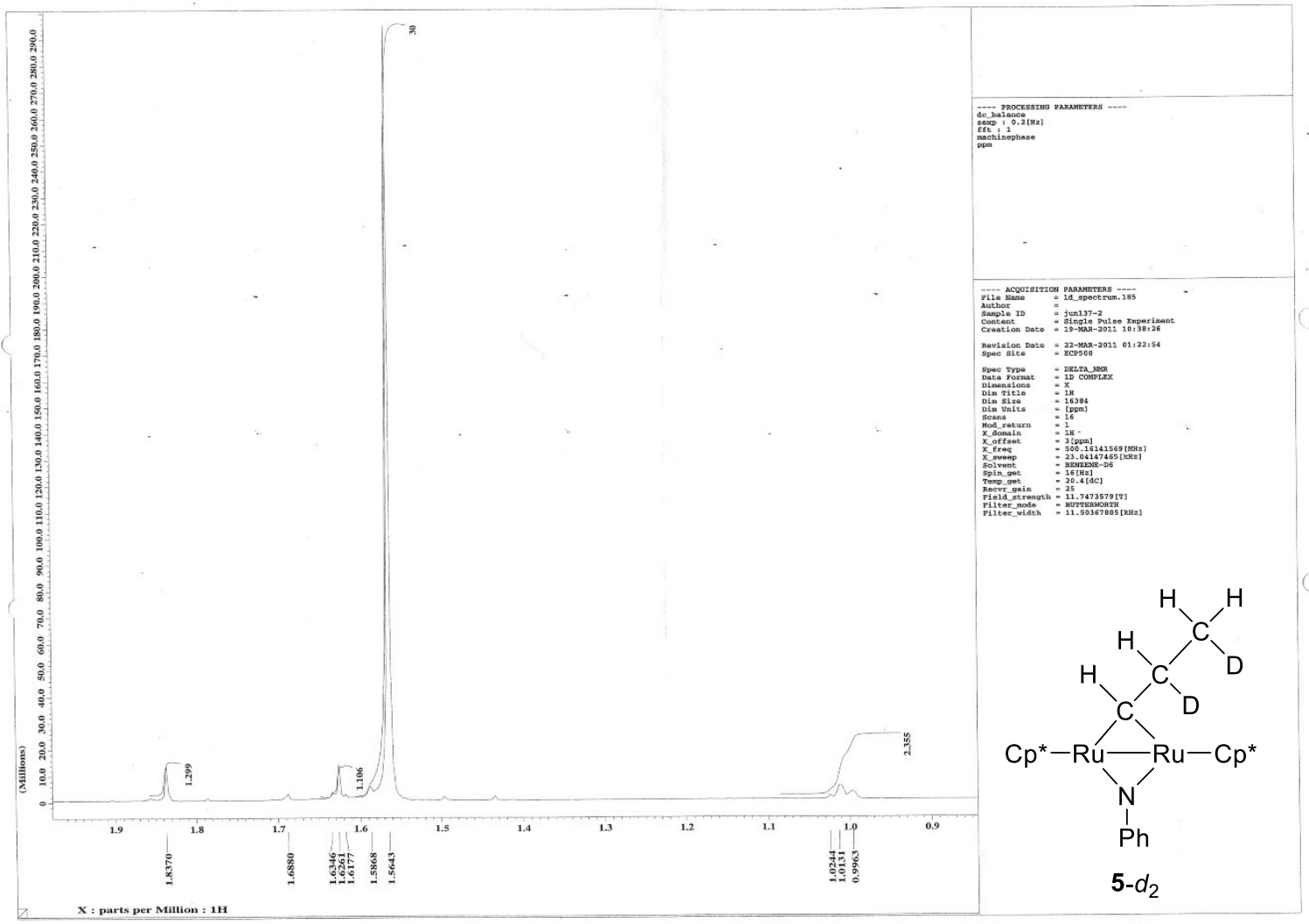

Figure S16 (expansion 1). $\quad{ }^{1} \mathrm{H}$ NMR spectrum of 5- $d_{2}\left(500 \mathrm{MHz}, \mathrm{C}_{6} \mathrm{D}_{6}\right)$. 


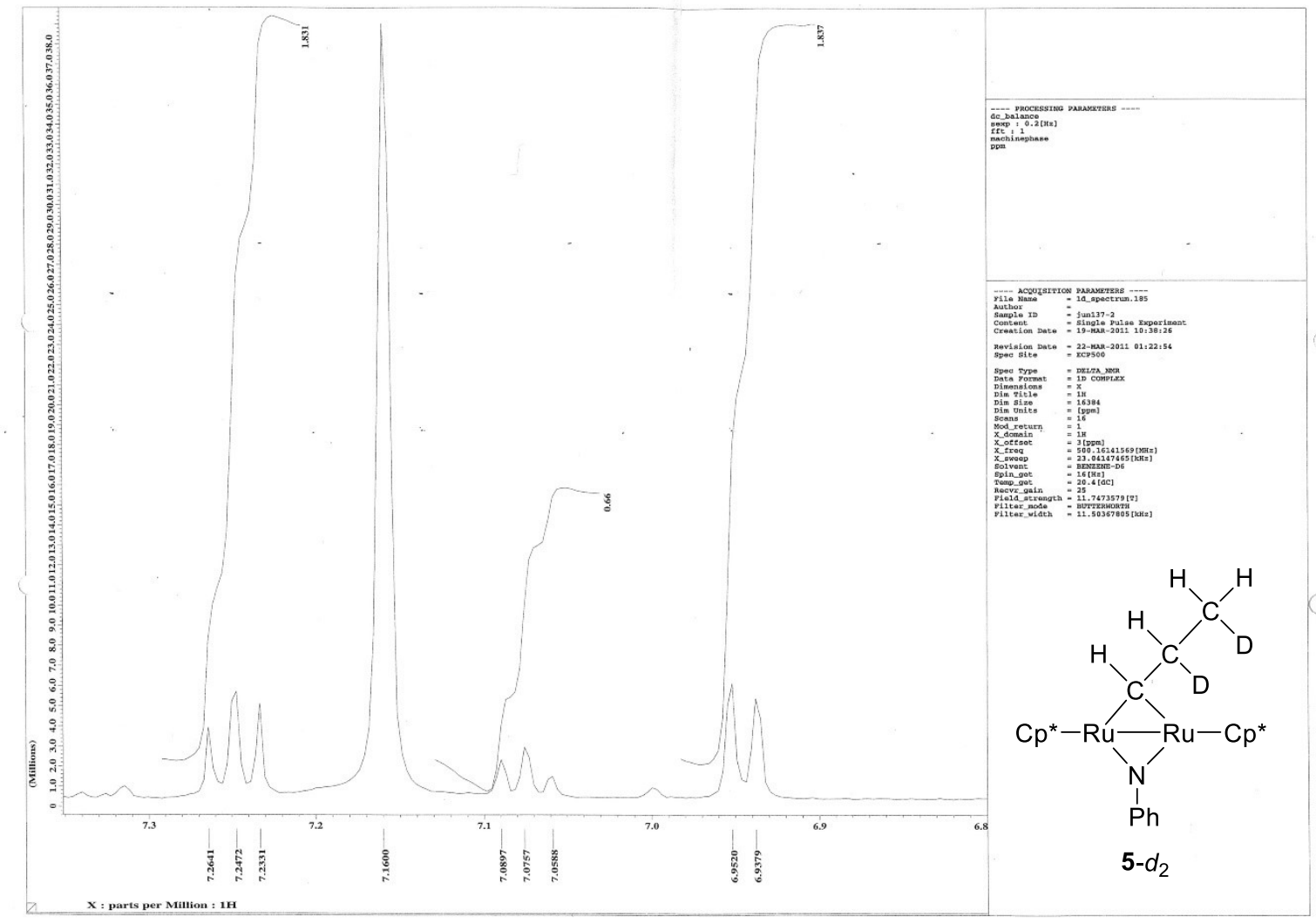

Figure S16 (expansion 2). $\quad{ }^{1} \mathrm{H}$ NMR spectrum of 5- $d_{2}\left(500 \mathrm{MHz}, \mathrm{C}_{6} \mathrm{D}_{6}\right)$. 


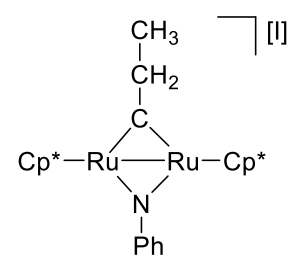

[6][]]
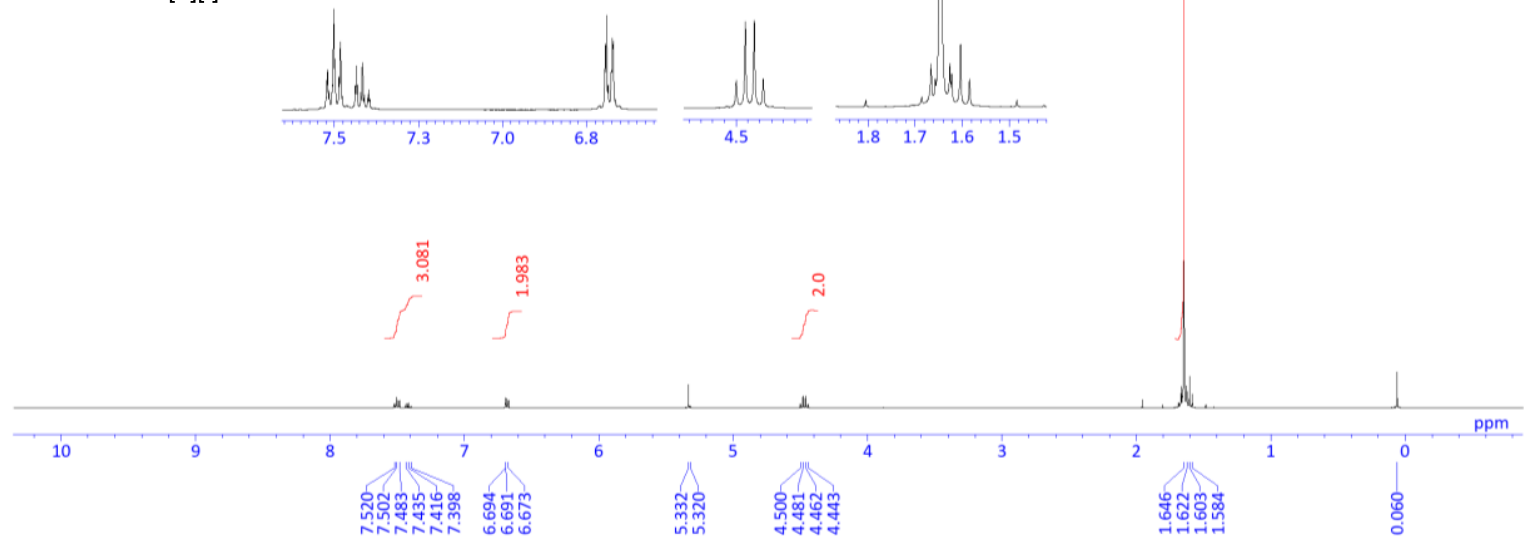

Figure S17. ${ }^{1} \mathrm{H}$ NMR spectrum of $[6][\mathrm{I}]\left(400 \mathrm{MHz}, \mathrm{CD}_{2} \mathrm{Cl}_{2}\right)$.

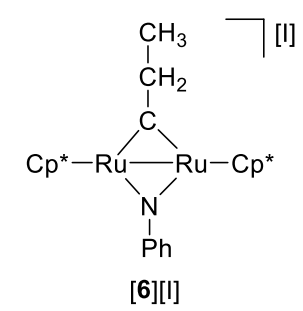

[6][I]

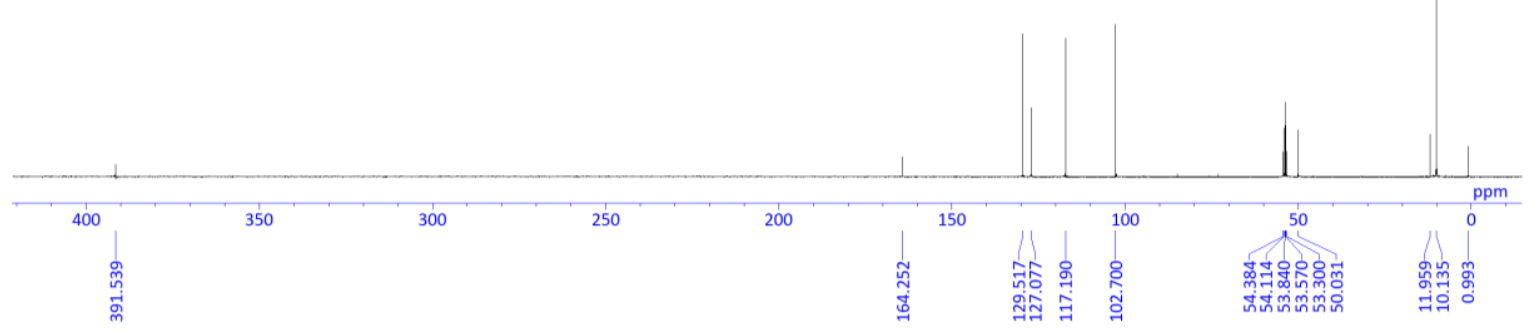

Figure S18. ${ }^{13} \mathrm{C}\left\{{ }^{1} \mathrm{H}\right\}$ NMR spectrum of [6][I] $\left(101 \mathrm{MHz}, \mathrm{CD}_{2} \mathrm{Cl}_{2}\right)$. 


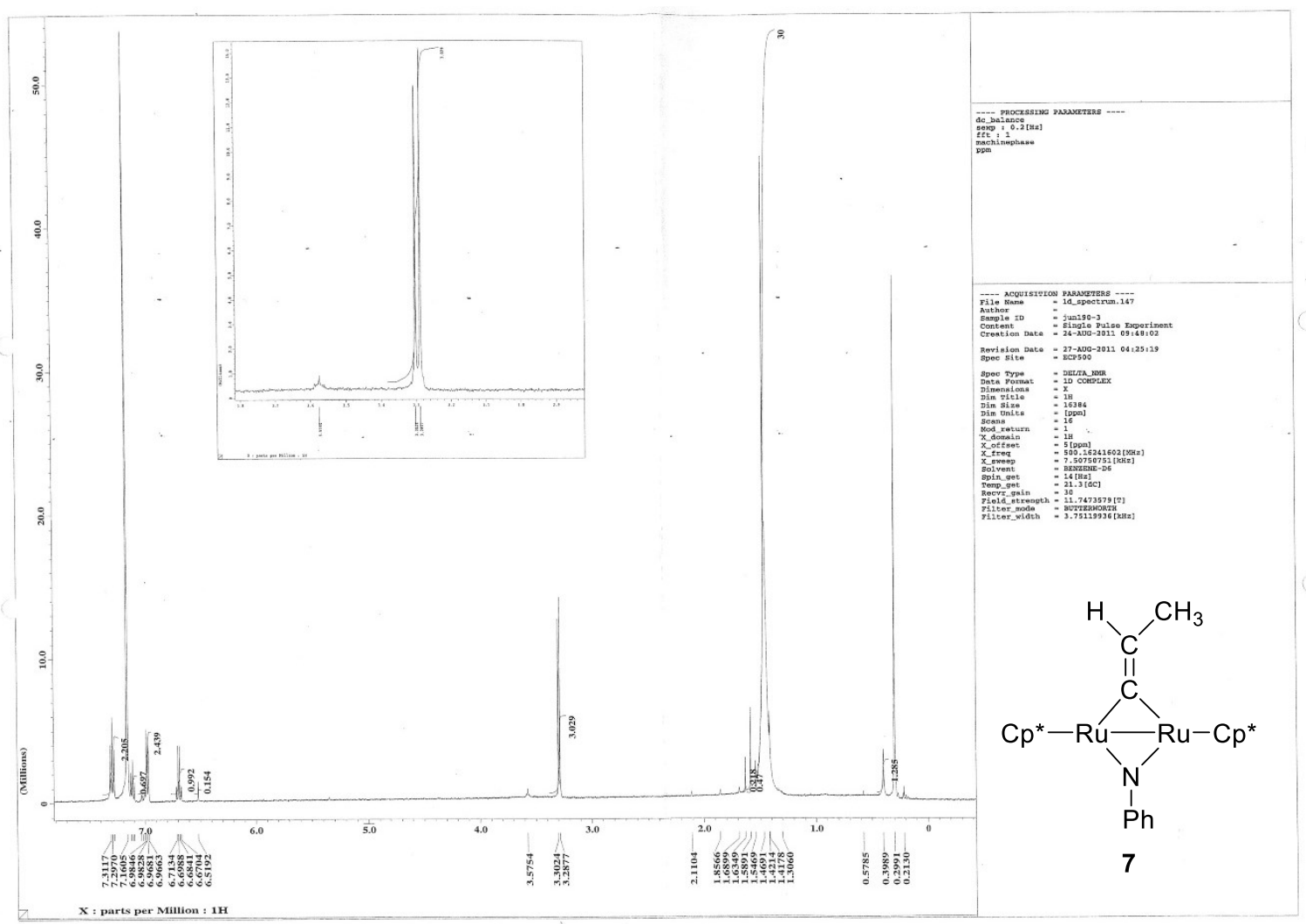

Figure S19. $\quad{ }^{1} \mathrm{H}$ NMR spectrum of $7\left(500 \mathrm{MHz}, \mathrm{C}_{6} \mathrm{D}_{6}\right)$. 


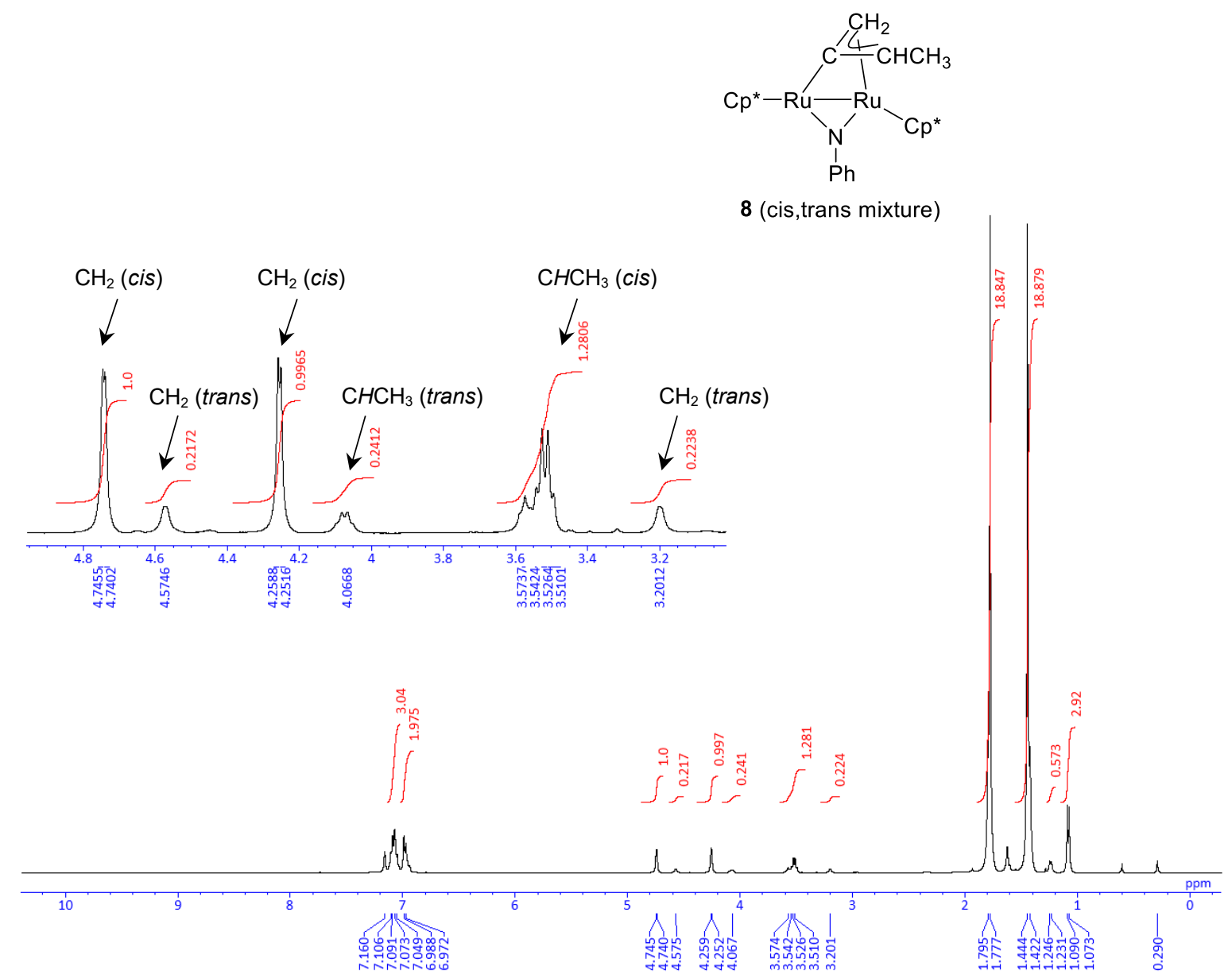

Figure S20. ${ }^{1} \mathrm{H}$ NMR spectrum of $8\left(400 \mathrm{MHz}, \mathrm{C}_{6} \mathrm{D}_{6}\right)$.

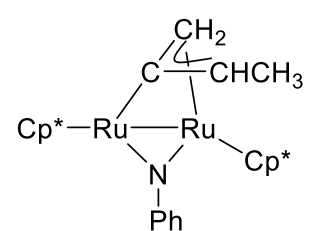

8 (cis,trans mixture)

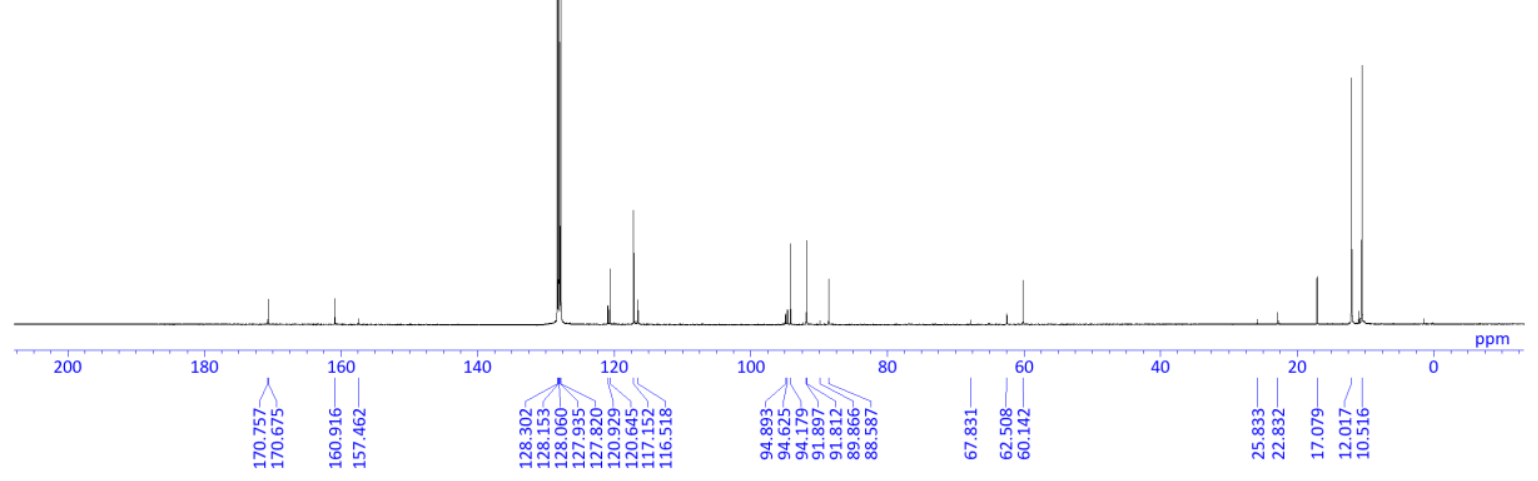

Figure S21. ${ }^{13} \mathrm{C}\left\{{ }^{1} \mathrm{H}\right\}$ NMR spectrum of $8\left(101 \mathrm{MHz}, \mathrm{C}_{6} \mathrm{D}_{6}\right)$. 
- ${ }^{13} \mathrm{CH}_{2}$ for cis-8- ${ }^{13} \mathrm{C}$

${ }^{13} \mathrm{CH}_{2}$ for trans $-8-{ }^{13} \mathrm{C}$

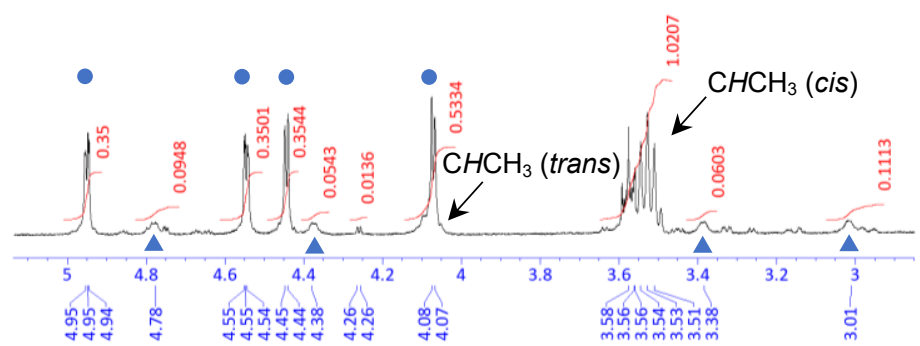

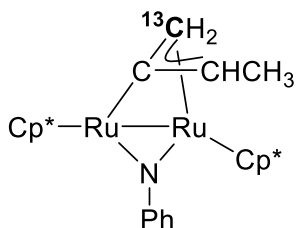

$8-{ }^{13} \mathrm{C}$

(cis,trans mixture)

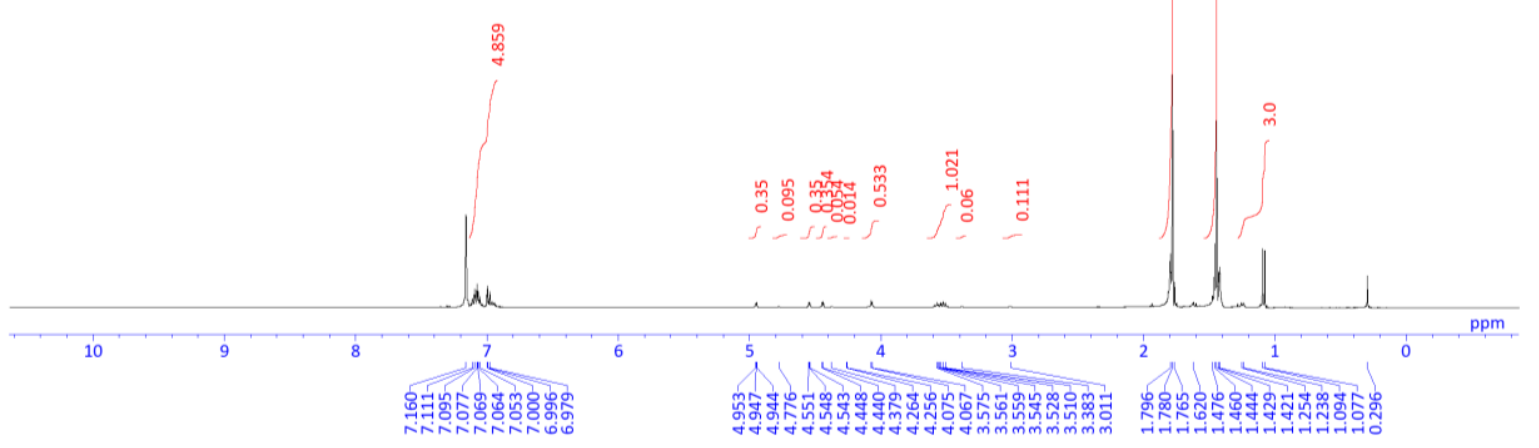

Figure S22. ${ }^{1} \mathrm{H}$ NMR spectrum of $\mathbf{8}^{13} \mathrm{C}\left(400 \mathrm{MHz}, \mathrm{C}_{6} \mathrm{D}_{6}\right)$.

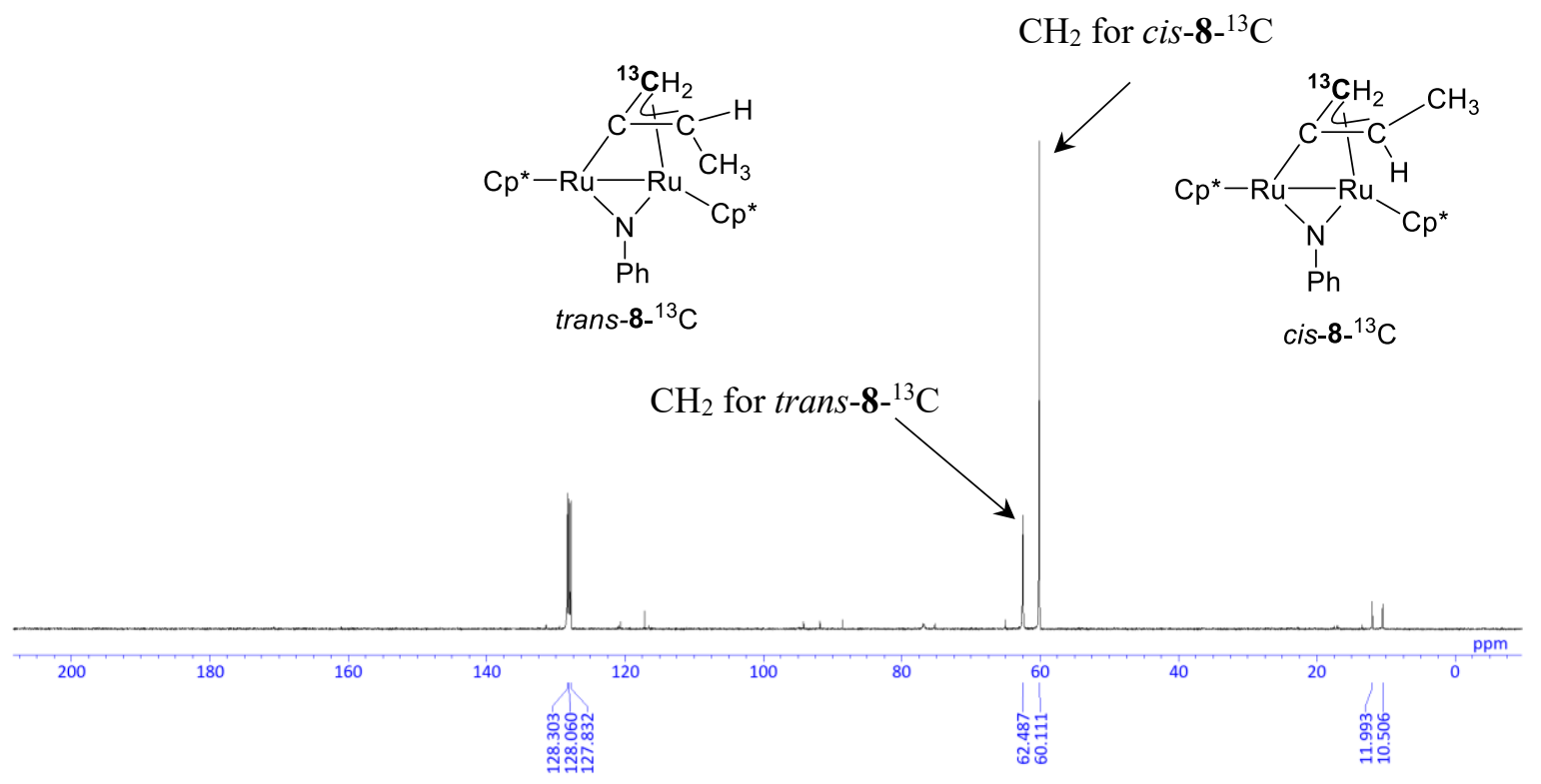

Figure S23. ${ }^{13} \mathrm{C}\left\{{ }^{1} \mathrm{H}\right\}$ NMR spectrum of $8-{ }^{13} \mathrm{C}\left(101 \mathrm{MHz}, \mathrm{C}_{6} \mathrm{D}_{6}\right)$. 

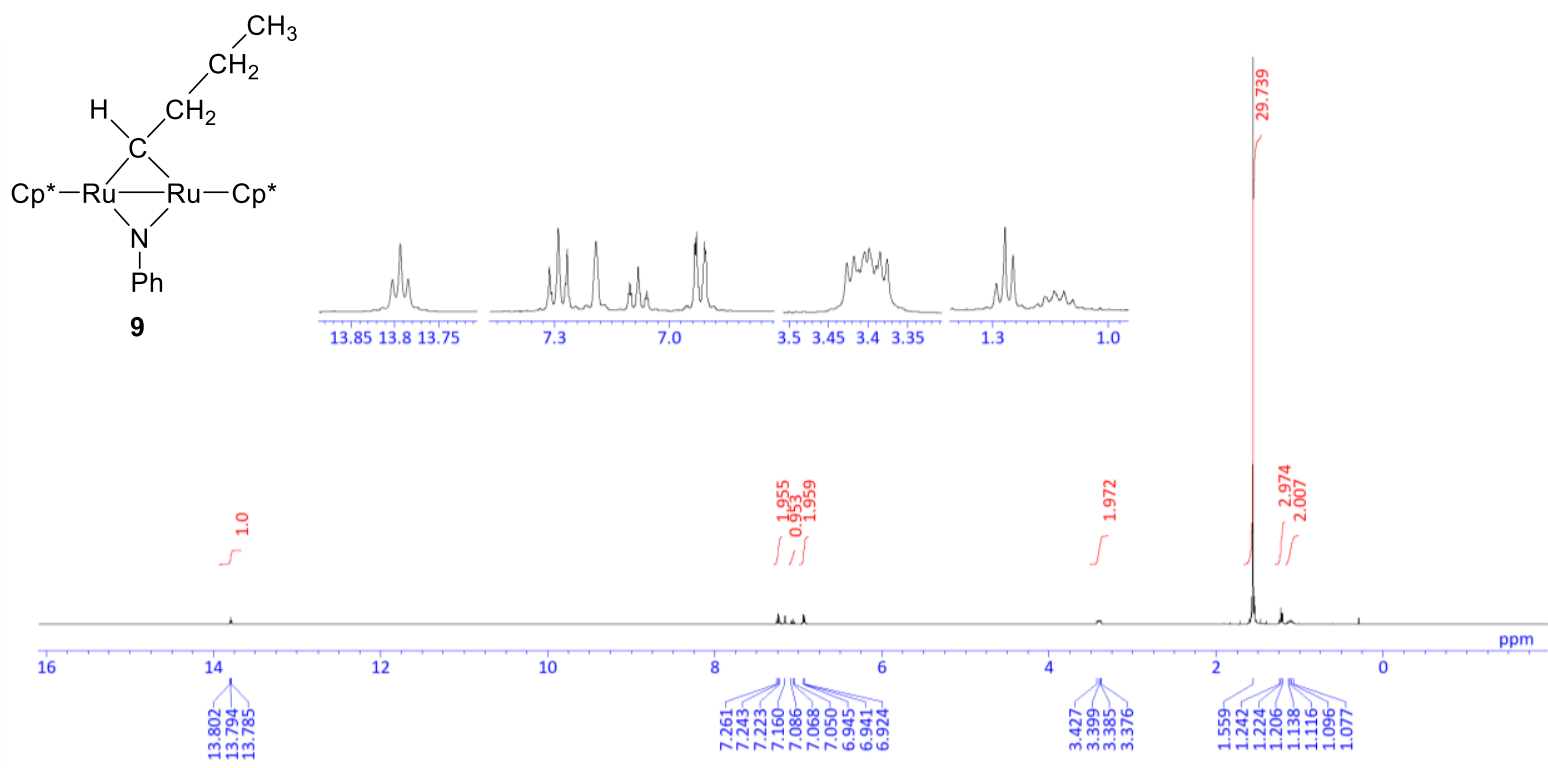

Figure S24. ${ }^{1} \mathrm{H}$ NMR spectrum of $9\left(400 \mathrm{MHz}, \mathrm{C}_{6} \mathrm{D}_{6}\right)$.

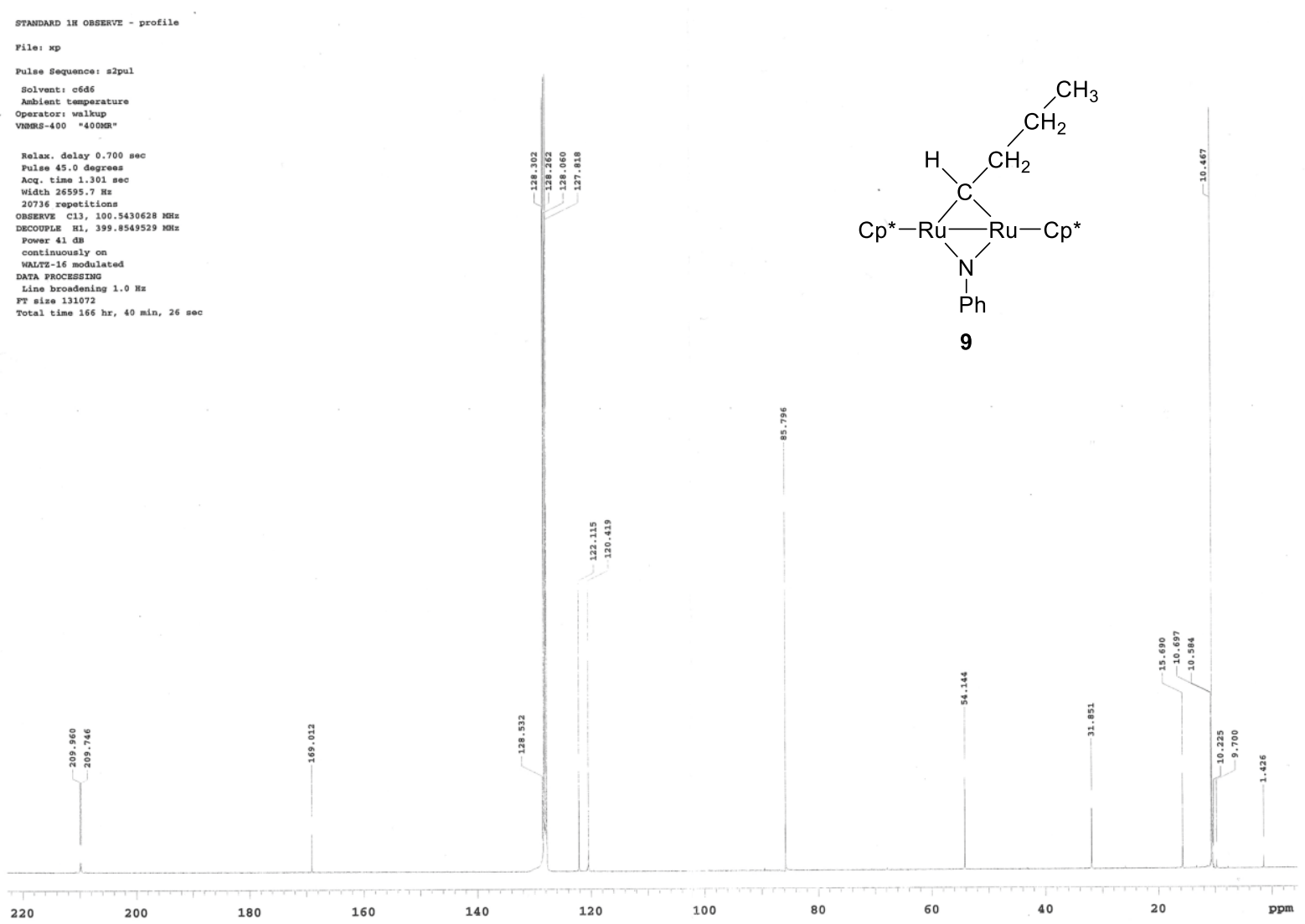

Figure S25. ${ }^{13} \mathrm{C}\left\{{ }^{1} \mathrm{H}\right\}$ NMR spectrum of $9\left(101 \mathrm{MHz}, \mathrm{C}_{6} \mathrm{D}_{6}\right)$. 


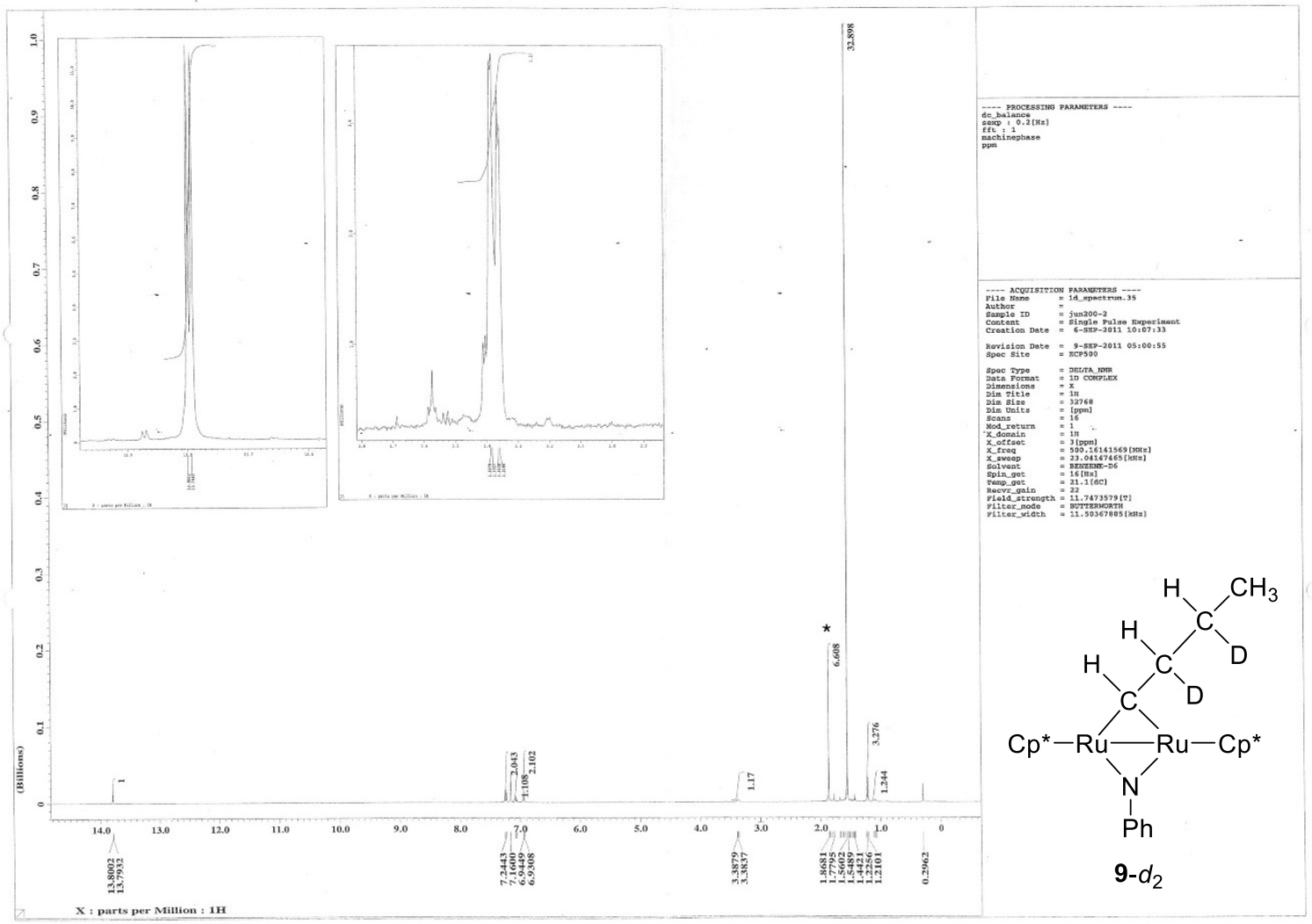

Figure S26. $\quad{ }^{1} \mathrm{H}$ NMR spectrum of 9- $d_{2}\left(500 \mathrm{MHz}, \mathrm{C}_{6} \mathrm{D}_{6}\right) . \quad$ *impurity.

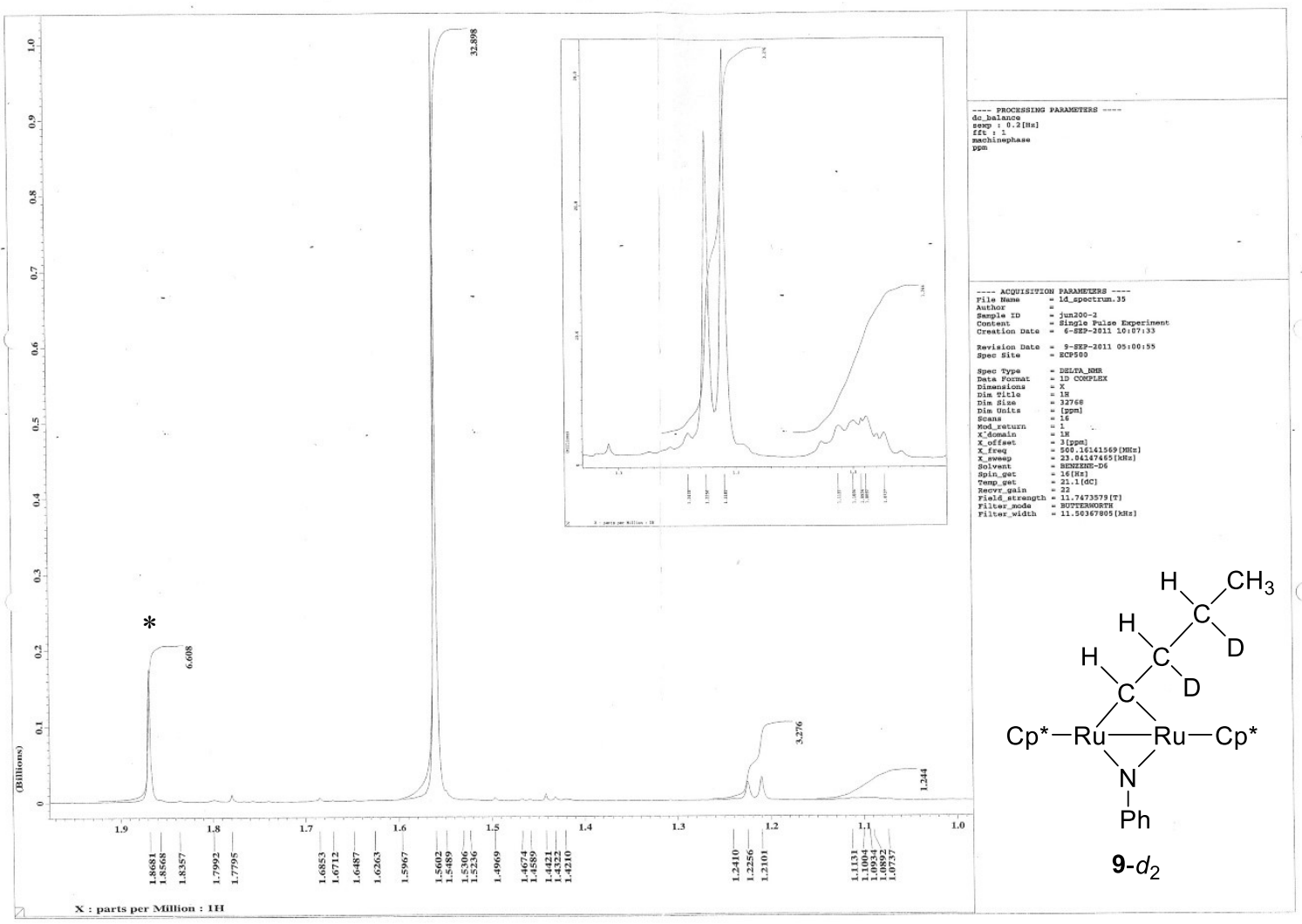

Figure S26 (expansion 1). $\quad{ }^{1} \mathrm{H}$ NMR spectrum of 9- $d_{2}\left(500 \mathrm{MHz}, \mathrm{C}_{6} \mathrm{D}_{6}\right)$. *impurity. 

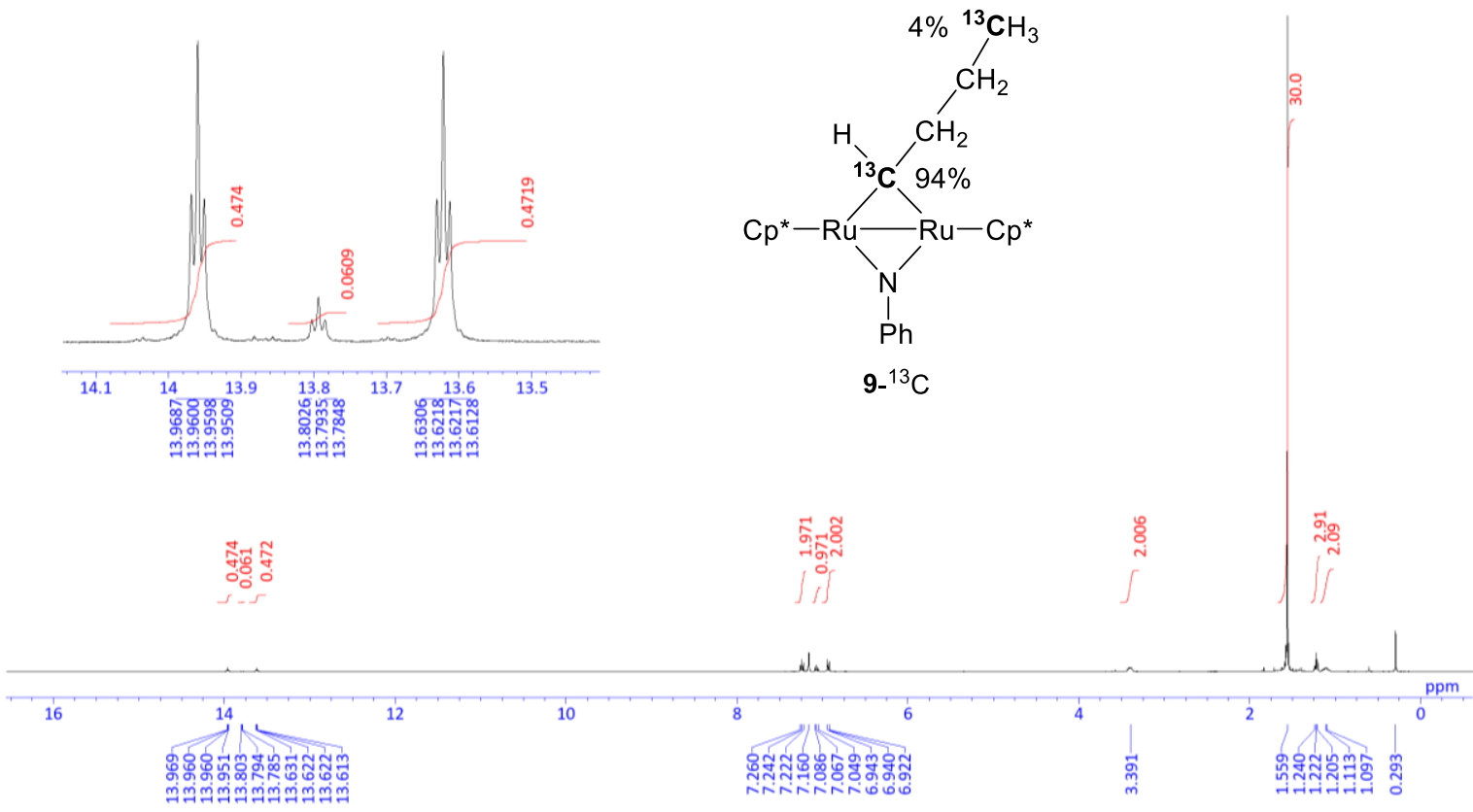

Figure S27. ${ }^{1} \mathrm{H}$ NMR spectrum of $9-{ }^{13} \mathrm{C}\left(400 \mathrm{MHz}, \mathrm{C}_{6} \mathrm{D}_{6}\right)$.

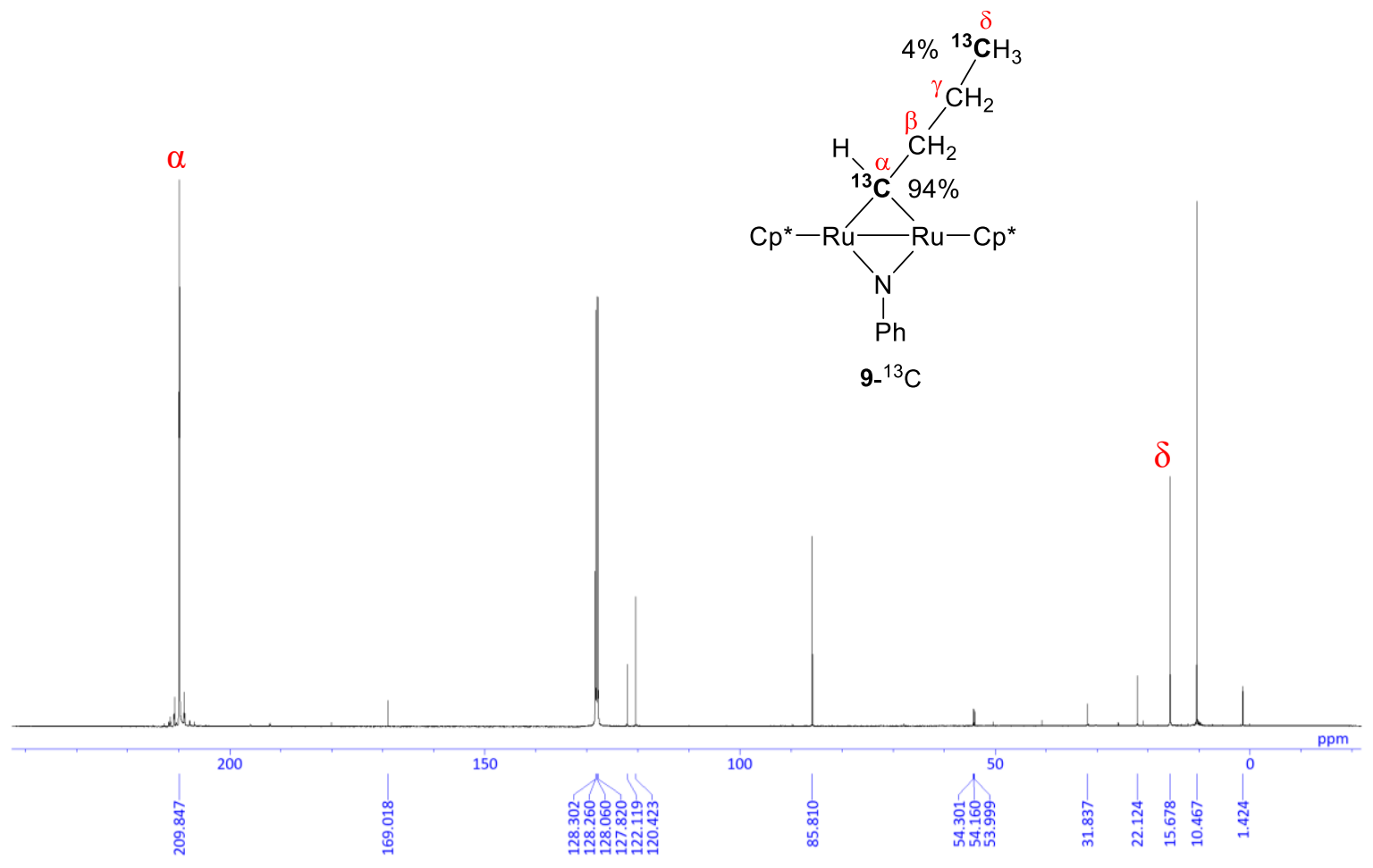

Figure S28. ${ }^{13} \mathrm{C}\left\{{ }^{1} \mathrm{H}\right\}$ NMR spectrum of 9- ${ }^{13} \mathrm{C}\left(101 \mathrm{MHz}, \mathrm{C}_{6} \mathrm{D}_{6}\right)$. 


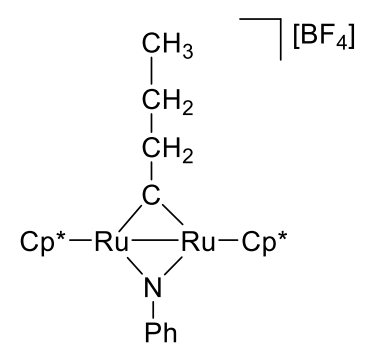

[10][BF $\mathrm{BF}_{4}$
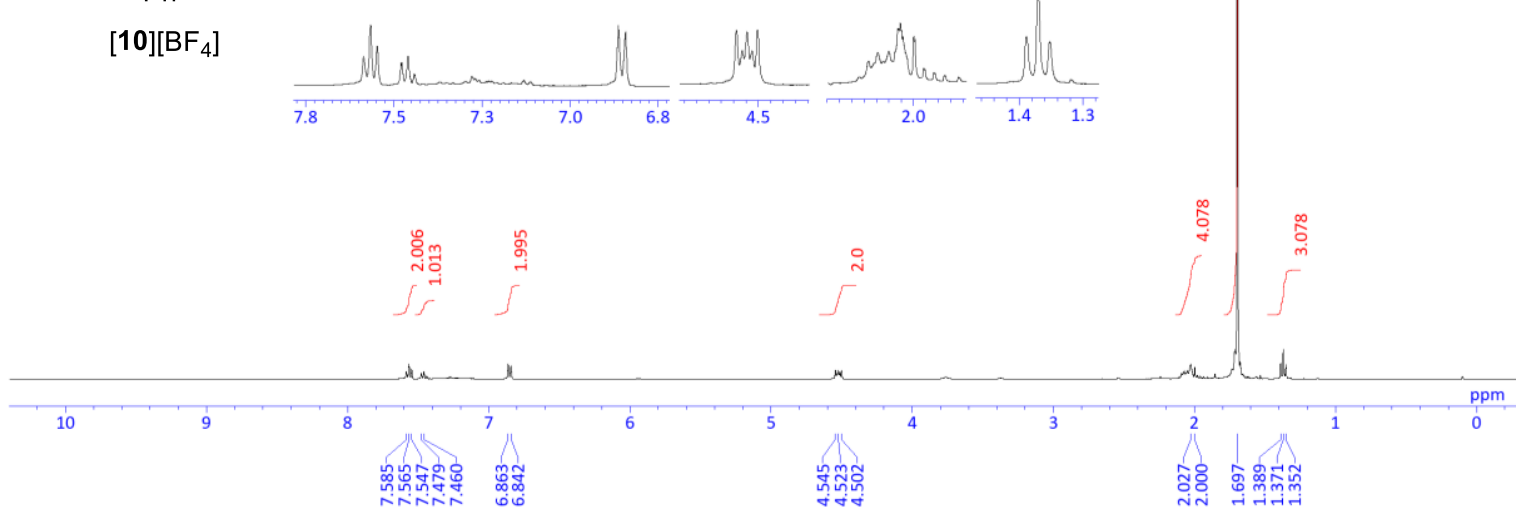

Figure S29. ${ }^{1} \mathrm{H}$ NMR spectrum of $[\mathbf{1 0}]\left[\mathrm{BF}_{4}\right]\left(400 \mathrm{MHz}\right.$, acetone- $\left.d_{6}\right)$.

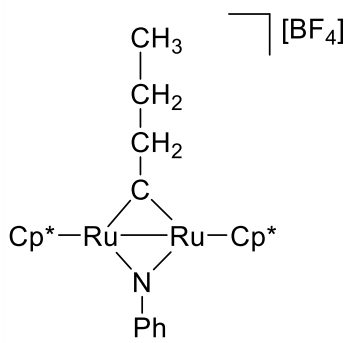

$[10]\left[\mathrm{BF}_{4}\right]$

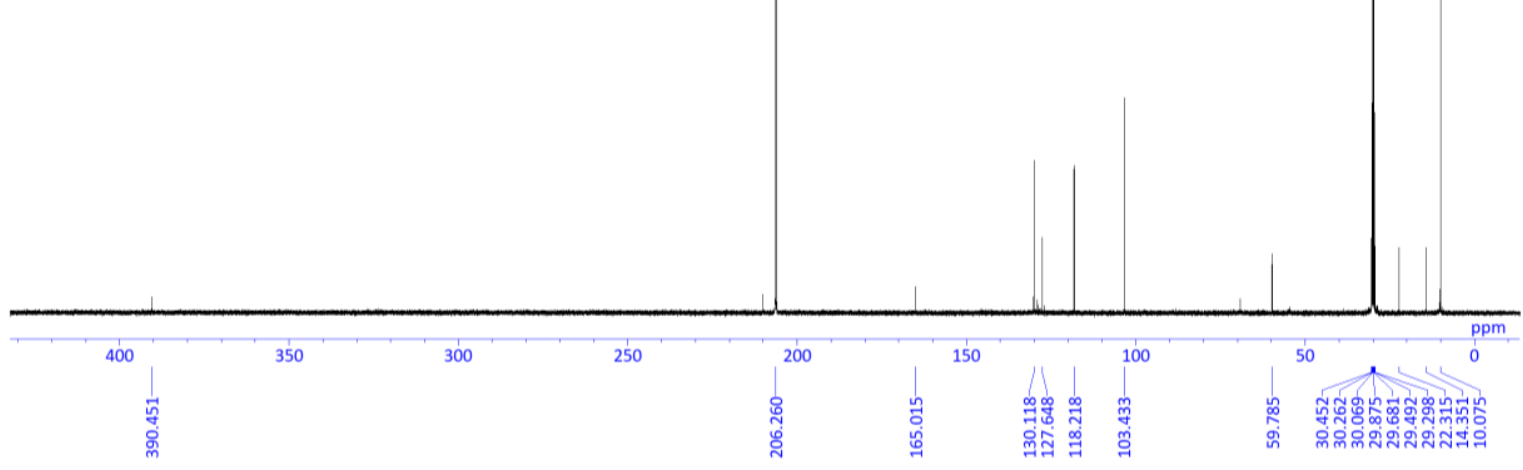

Figure S30. ${ }^{13} \mathrm{C}\left\{{ }^{1} \mathrm{H}\right\}$ NMR spectrum of $[10]\left[\mathrm{BF}_{4}\right]\left(101 \mathrm{MHz}\right.$, acetone- $\left.d_{6}\right)$. 

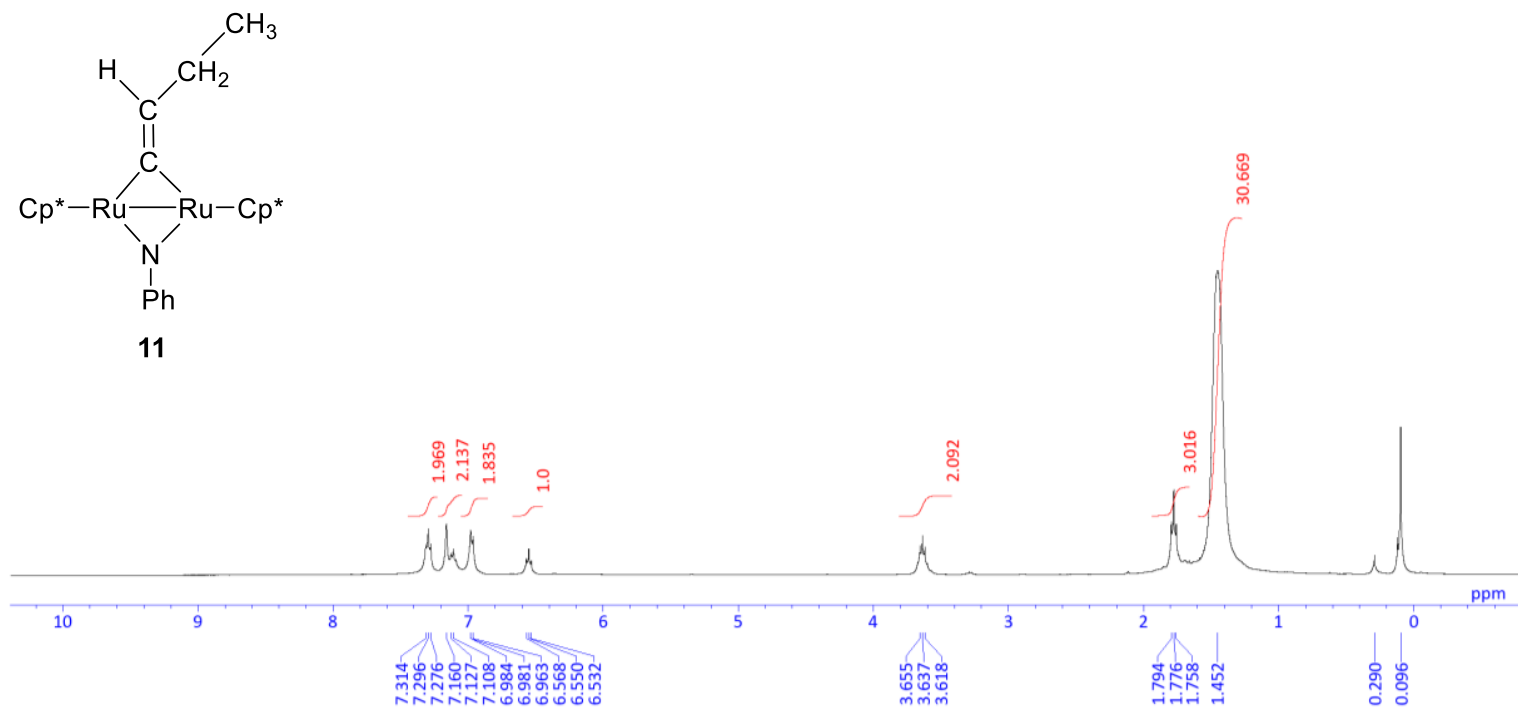

Figure S31. ${ }^{1} \mathrm{H}$ NMR spectrum of $11\left(400 \mathrm{MHz}, \mathrm{C}_{6} \mathrm{D}_{6}\right)$.

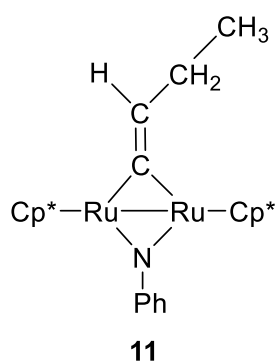

11

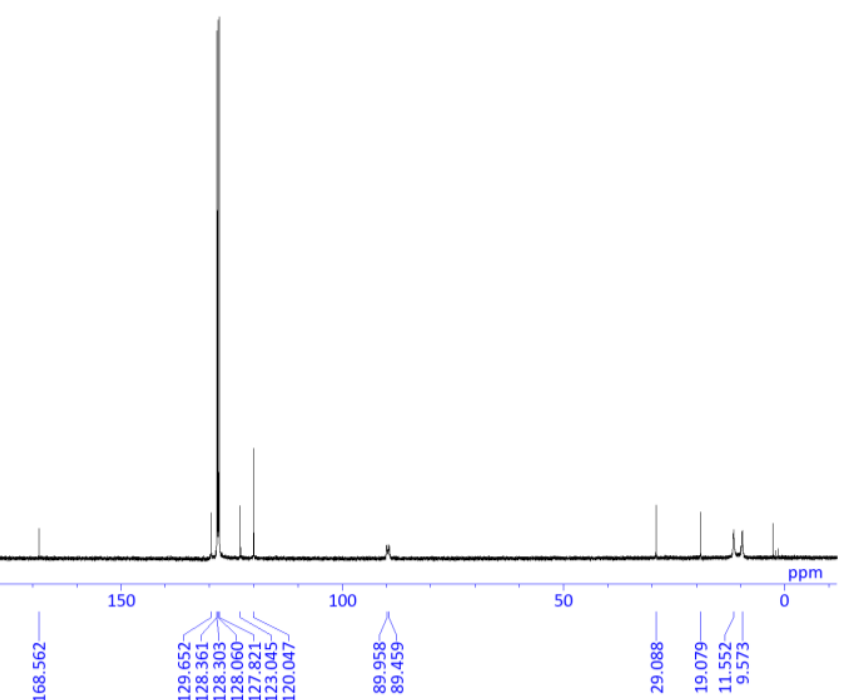

Figure S32. ${ }^{13} \mathrm{C}\left\{{ }^{1} \mathrm{H}\right\}$ NMR spectrum of $11\left(101 \mathrm{MHz}, \mathrm{C}_{6} \mathrm{D}_{6}\right)$. 


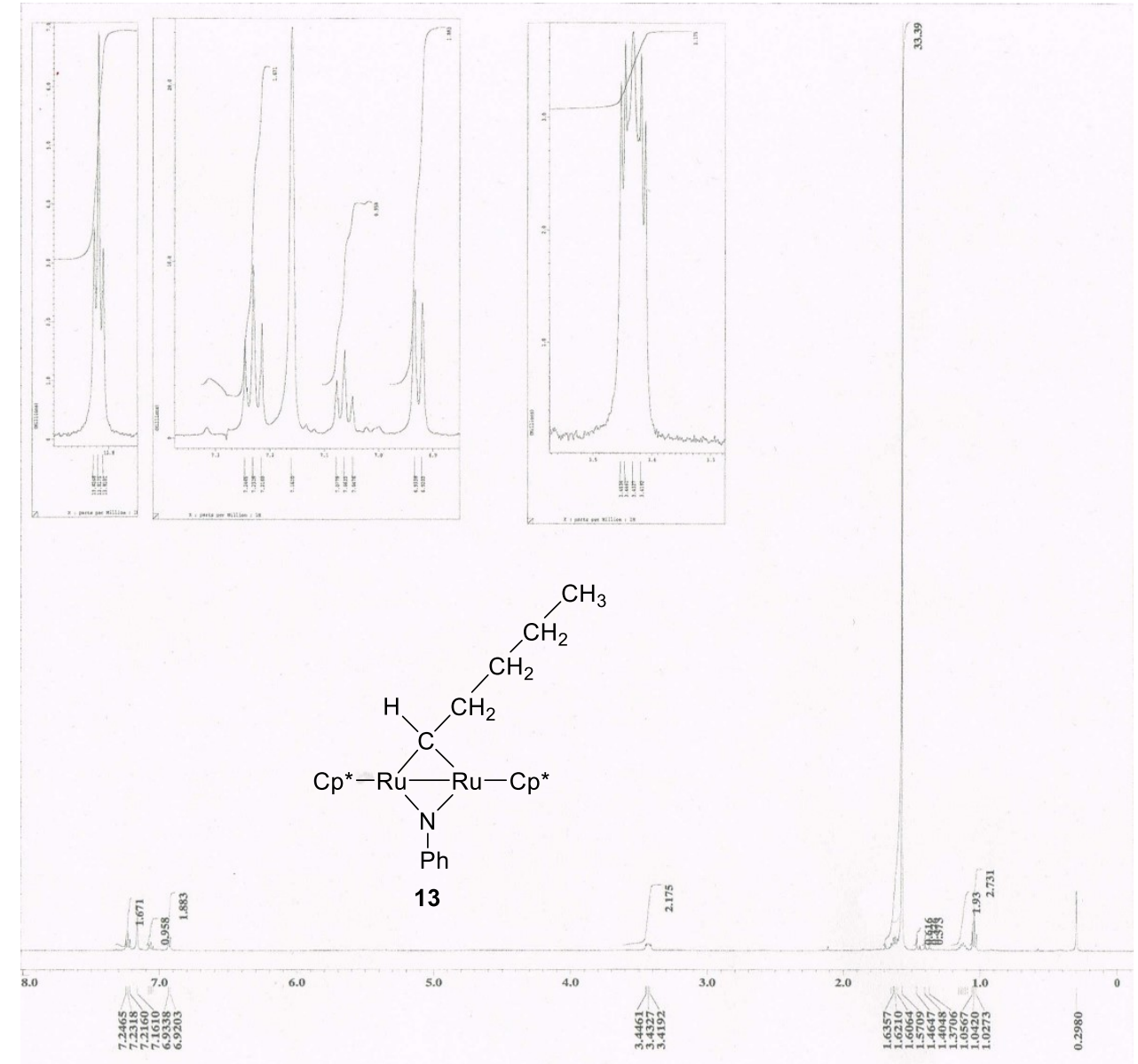

Figure S33. $\quad{ }^{1} \mathrm{H}$ NMR spectrum of $13\left(400 \mathrm{MHz}, \mathrm{C}_{6} \mathrm{D}_{6}\right)$.
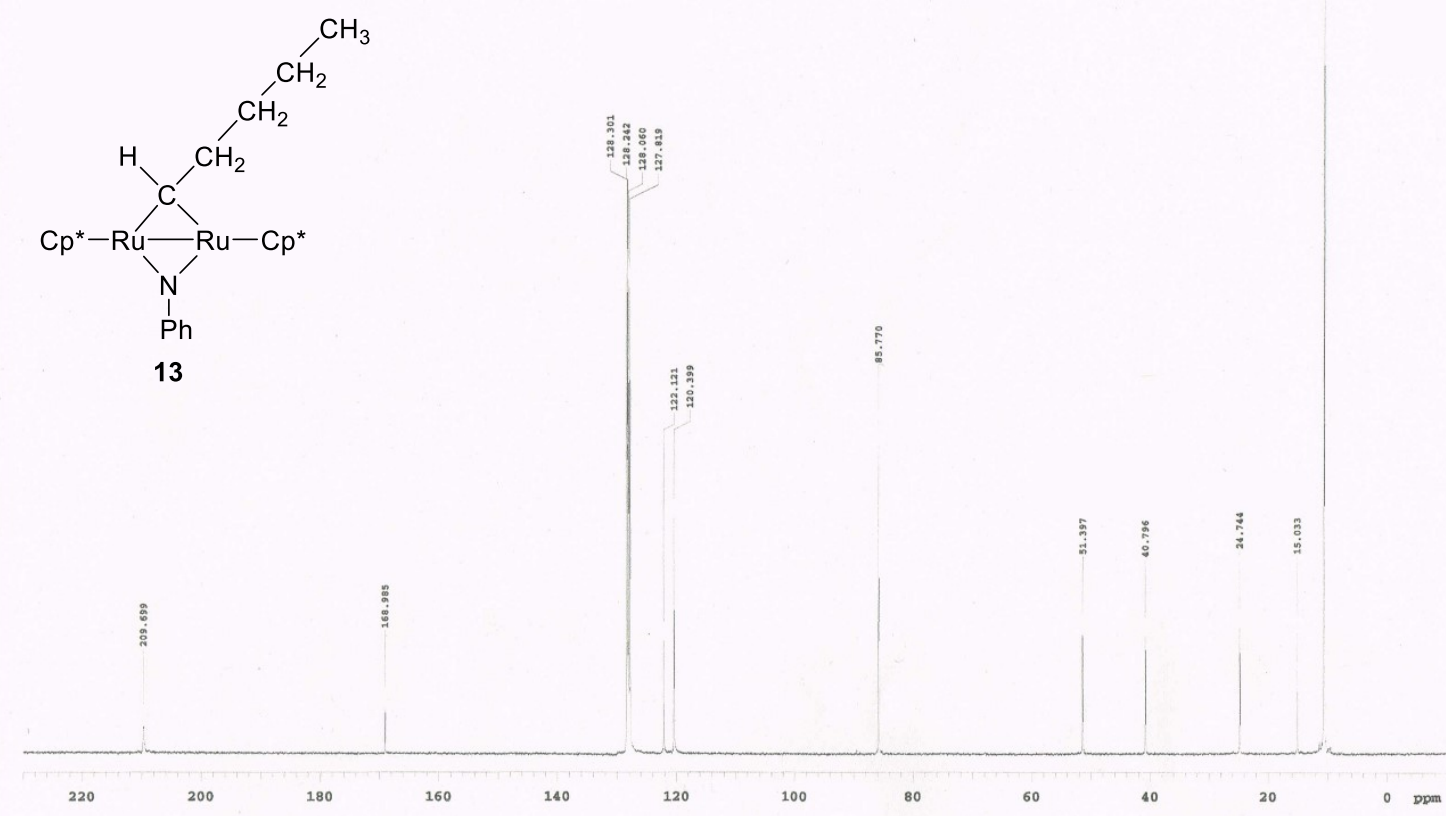

Figure S34. ${ }^{13} \mathrm{C}\left\{{ }^{1} \mathrm{H}\right\}$ NMR spectrum of $\mathbf{1 3}\left(101 \mathrm{MHz}, \mathrm{C}_{6} \mathrm{D}_{6}\right)$. 


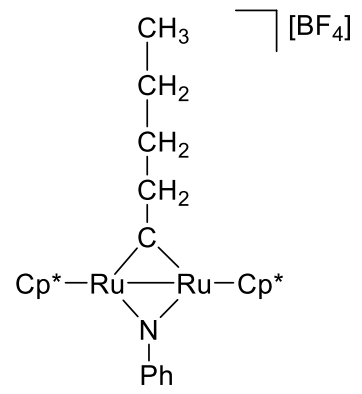

$[14]\left[\mathrm{BF}_{4}\right]$

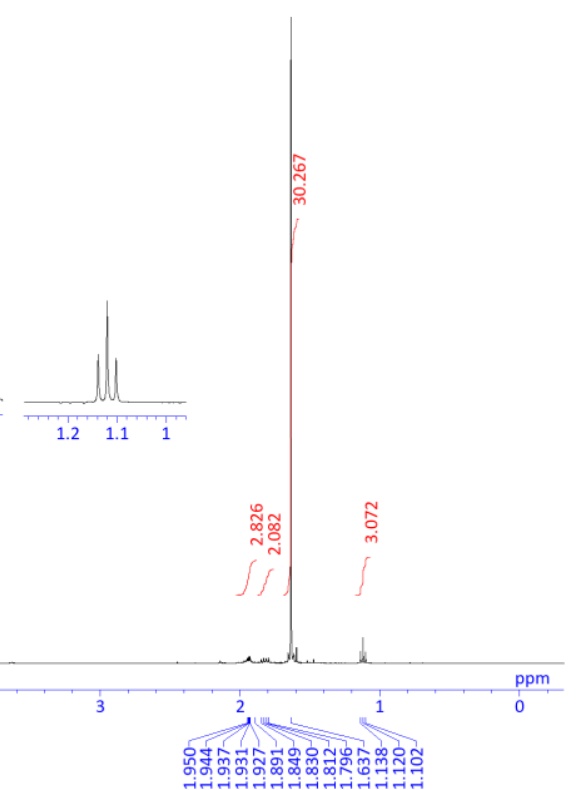

Figure S35. ${ }^{1} \mathrm{H}$ NMR spectrum of $[14]\left[\mathrm{BF}_{4}\right]\left(400 \mathrm{MHz}, \mathrm{CD}_{3} \mathrm{CN}\right)$.

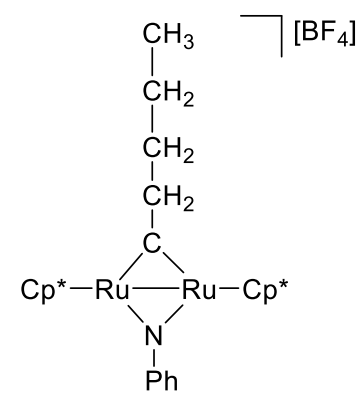

[14] $\left[\mathrm{BF}_{4}\right]$

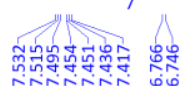

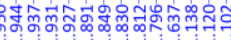

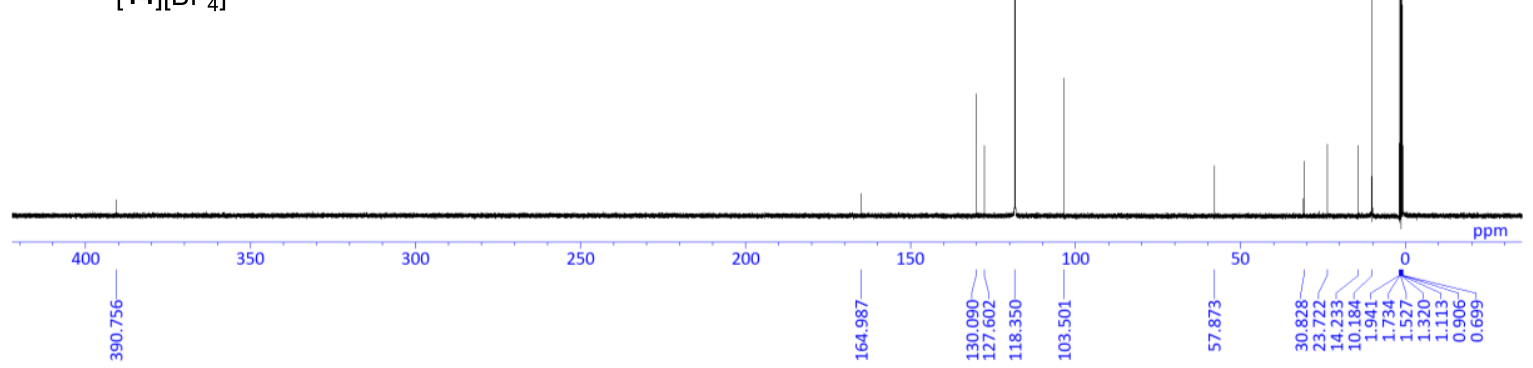

Figure S36. ${ }^{13} \mathrm{C}\left\{{ }^{1} \mathrm{H}\right\}$ NMR spectrum of $[14]\left[\mathrm{BF}_{4}\right]\left(101 \mathrm{MHz}, \mathrm{CD}_{3} \mathrm{CN}\right)$. 

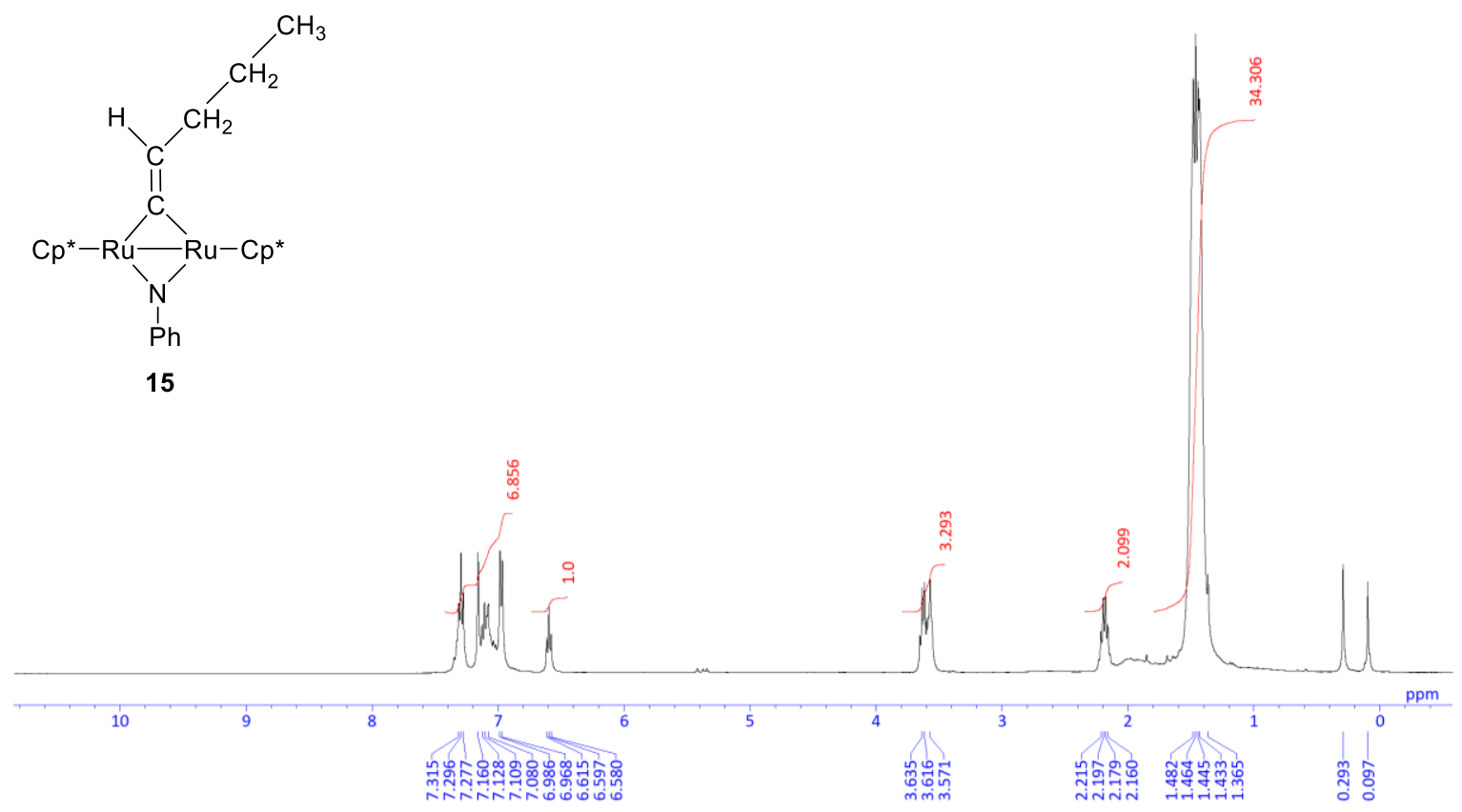

Figure S37. ${ }^{1} \mathrm{H}$ NMR spectrum of $15\left(400 \mathrm{MHz}, \mathrm{C}_{6} \mathrm{D}_{6}\right)$.

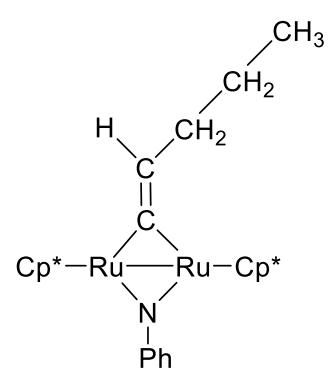

15

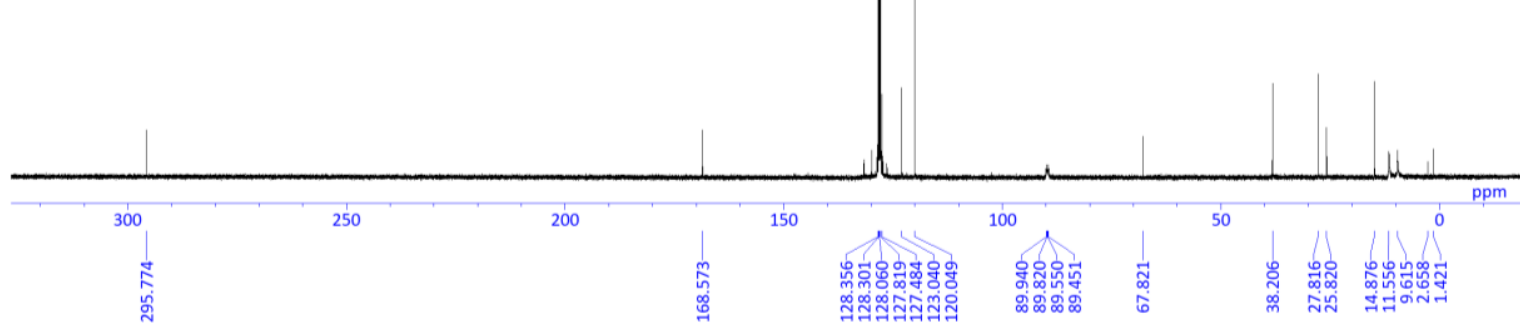

Figure S38. ${ }^{13} \mathrm{C}\left\{{ }^{1} \mathrm{H}\right\}$ NMR spectrum of $\mathbf{1 5}\left(101 \mathrm{MHz}, \mathrm{C}_{6} \mathrm{D}_{6}\right)$. 

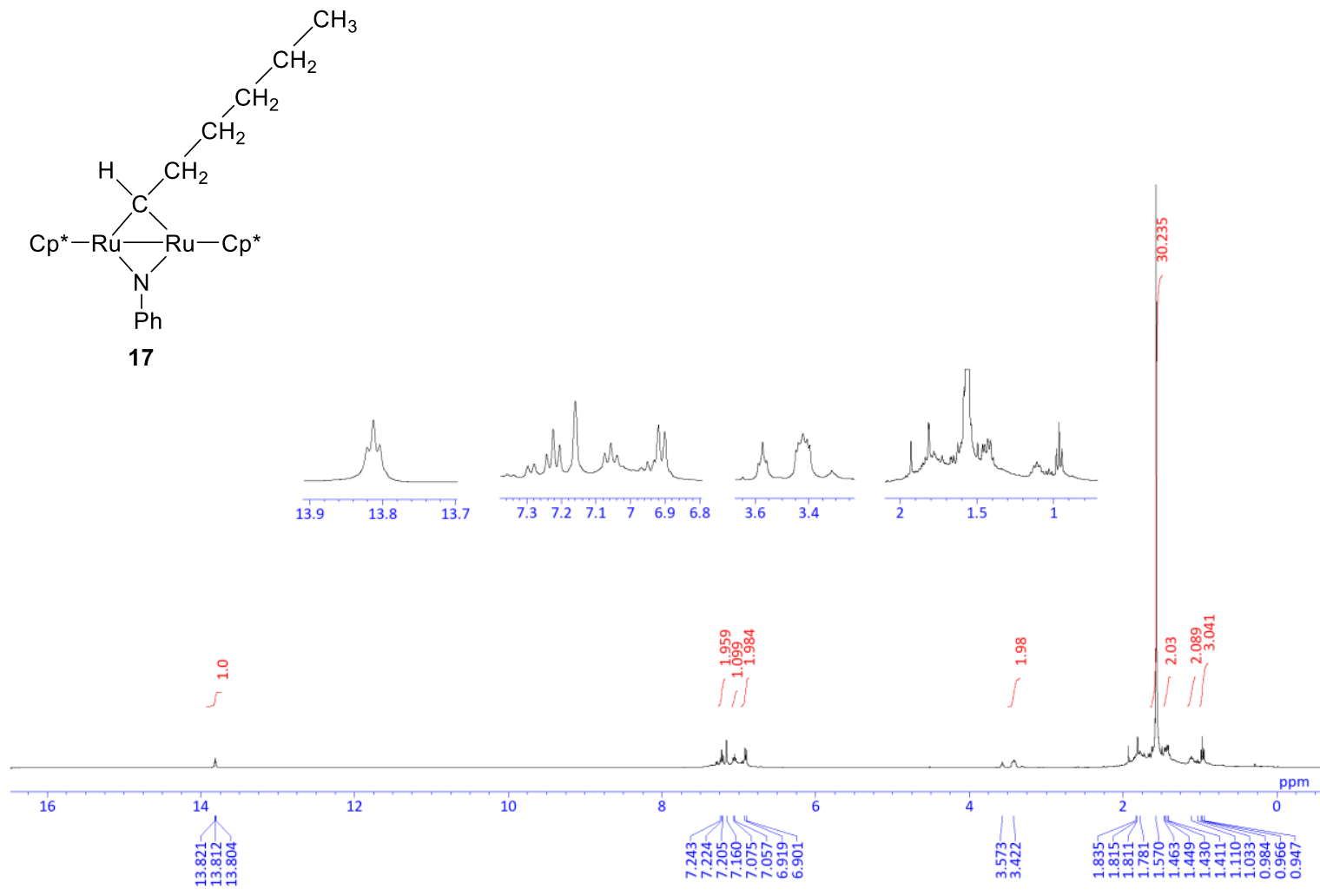

Figure S39. ${ }^{1} \mathrm{H}$ NMR spectrum of $17\left(400 \mathrm{MHz}, \mathrm{C}_{6} \mathrm{D}_{6}\right)$.

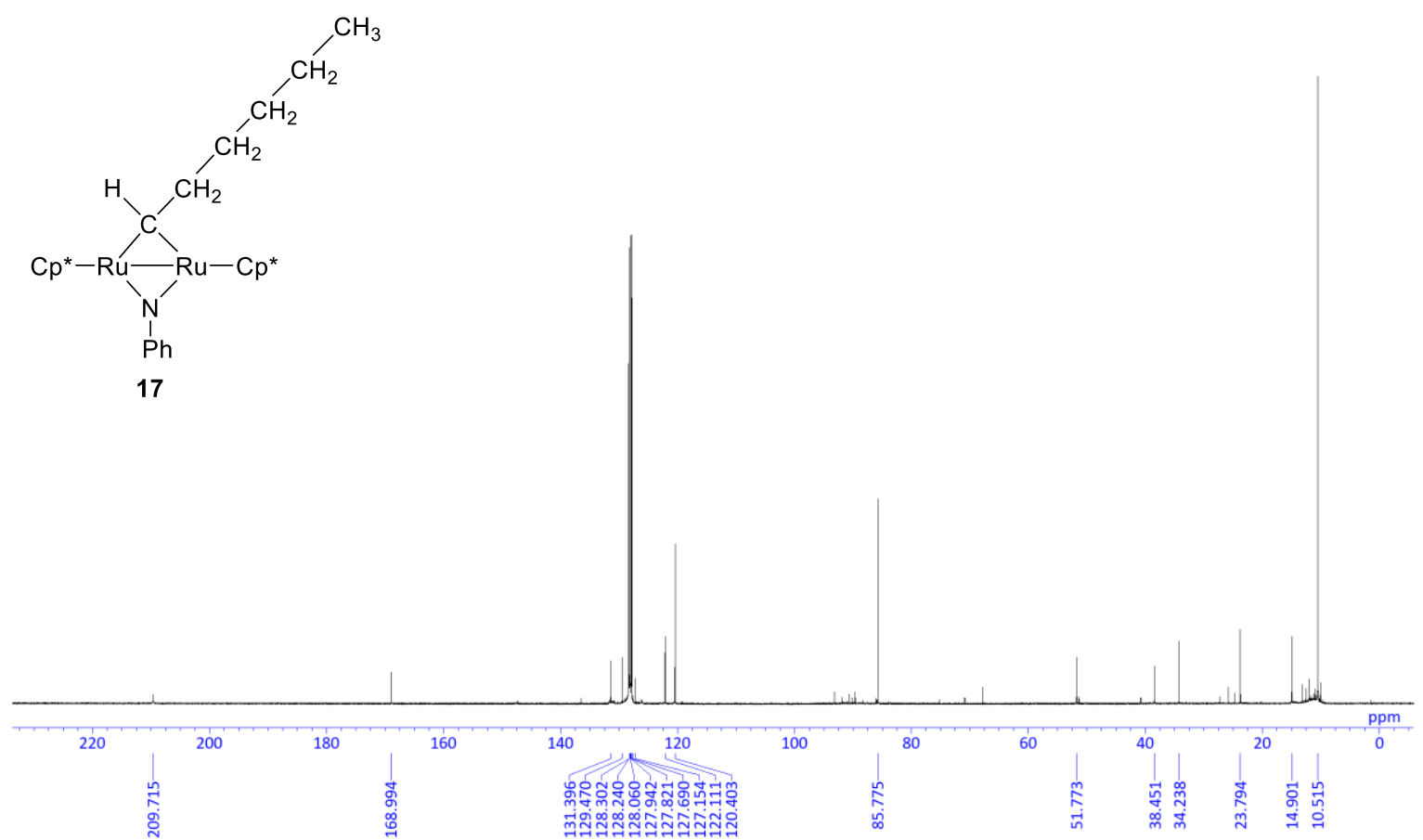

Figure S40. ${ }^{13} \mathrm{C}\left\{{ }^{1} \mathrm{H}\right\}$ NMR spectrum of $17\left(101 \mathrm{MHz}, \mathrm{C}_{6} \mathrm{D}_{6}\right)$. 


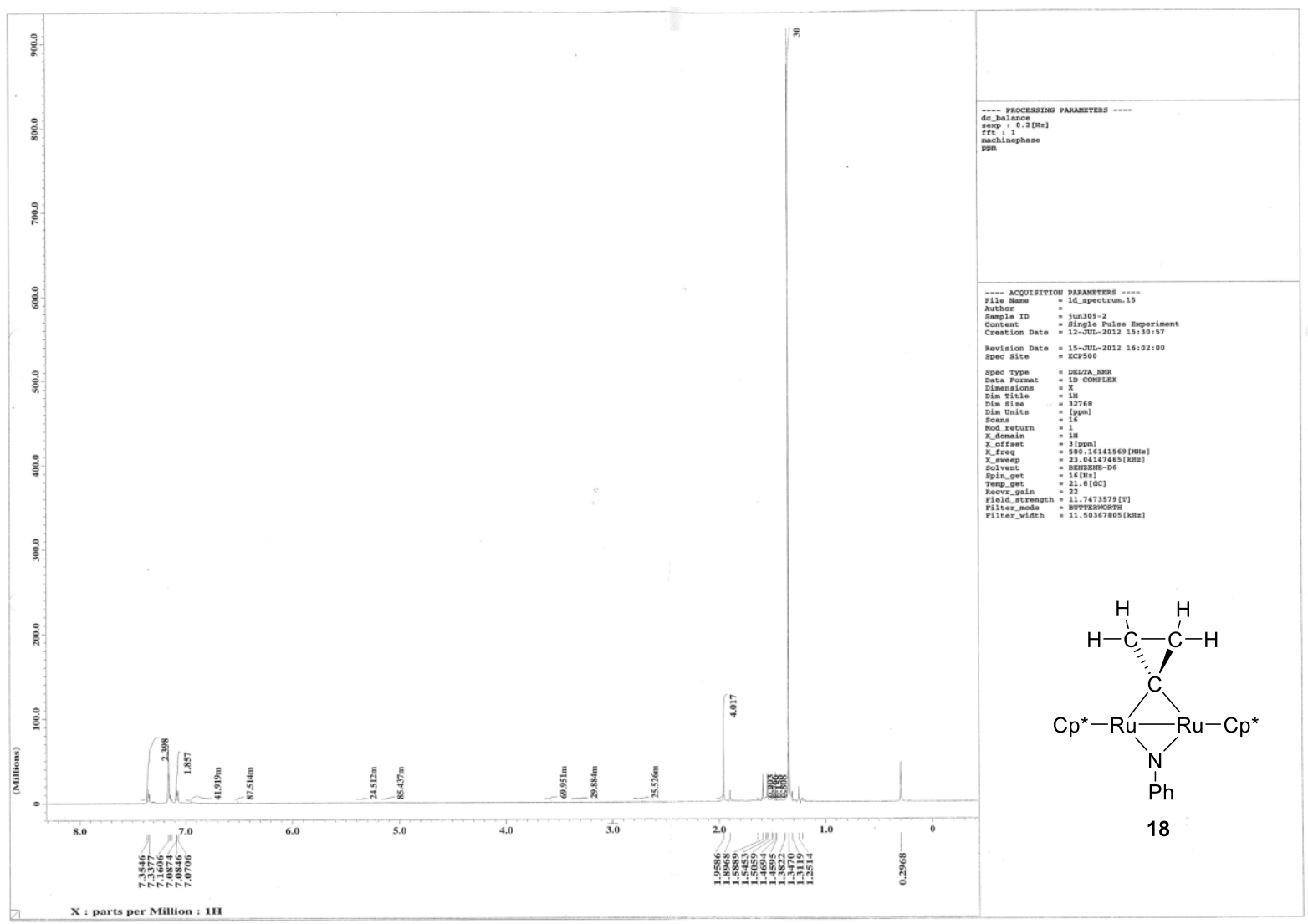

Figure S41. $\quad{ }^{1} \mathrm{H}$ NMR spectrum of $18\left(500 \mathrm{MHz}, \mathrm{C}_{6} \mathrm{D}_{6}\right)$. 


\section{X-ray Crystallography.}

Single crystals of each compound were prepared as described in the synthetic procedures. A well-shaped crystal of each sample was mounted on a sealed glass capillary. All measurements were performed on a Rigaku R-AXIS Rapid imaging plate detector with graphite monochromated Mo K $\alpha$ radiation $(\lambda=0.71069 \AA)$. The frame data were processed using Rigaku PROCESS-AUTO, ${ }^{5}$ and the reflection data were corrected for absorption with ABSCOR. ${ }^{6}$ The structures were solved by SHELXS-97 and refined by SHELXL-97. ${ }^{7}$ All non-hydrogen atoms were refined with anisotropic displacement parameters unless otherwise mentioned. Hydrogen atoms were placed at calculated positions and treated as riding models unless otherwise mentioned. Selected crystallographic data are summarized in Table S1.

Table S1. Crystallographic data for $\mathbf{3 , 4}$, cis-8.

\begin{tabular}{|c|c|c|c|}
\hline & 3 & 4 & $c i s-\mathbf{8}$ \\
\hline formula & $\mathrm{C}_{29} \mathrm{H}_{39} \mathrm{NRu}_{2}$ & $\mathrm{C}_{30} \mathrm{H}_{41} \mathrm{NRu}_{2}$ & $\mathrm{C}_{30} \mathrm{H}_{41} \mathrm{NRu}_{2}$ \\
\hline$M$ & 603.77 & 617.80 & 617.80 \\
\hline$T / \mathrm{K}$ & 293(2) & $293(2)$ & $293(2)$ \\
\hline size (mm) & $0.50 \times 0.30 \times 0.03$ & $0.45 \times 0.45 \times 0.40$ & $0.20 \times 0.10 \times 0.01$ \\
\hline crystal system & monoclinic & triclinic & triclinic \\
\hline space group & $P 2_{1} / n$ & $P-1$ & $P-1$ \\
\hline$Z$ & 4 & 2 & 2 \\
\hline$a(\AA)$ & $8.6457(3)$ & $8.6590(19)$ & $8.6585(6)$ \\
\hline$b(\AA)$ & $21.4885(6)$ & $8.784(2)$ & $11.3336(7)$ \\
\hline$c(\AA)$ & $14.4680(5)$ & $18.378(4)$ & $15.0539(8)$ \\
\hline$\alpha(\mathrm{deg})$ & 90.0000 & $96.457(9)$ & $96.412(7)$ \\
\hline$\beta(\operatorname{deg})$ & $98.983(7)$ & $97.333(8)$ & $99.908(7)$ \\
\hline$\gamma(\operatorname{deg})$ & 90.0000 & $103.308(8)$ & $105.780(7)$ \\
\hline$V\left(\AA^{3}\right)$ & $2654.94(16)$ & $1334.6(5)$ & $1380.69(17)$ \\
\hline$D_{\text {calc }}\left(\mathrm{g} / \mathrm{cm}^{3}\right)$ & 1.510 & 1.537 & 1.486 \\
\hline$\mu\left(\mathrm{mm}^{-1}\right)$ & 1.154 & 1.150 & 1.111 \\
\hline reflns collected & 23760 & 12577 & 13330 \\
\hline unique reflns & 5928 & 6047 & 6237 \\
\hline GOF on $F^{2}$ & 1.086 & 0.899 & 0.986 \\
\hline $\mathrm{R} 1[I>2 \sigma(I)]^{a}$ & 0.0316 & 0.0337 & 0.0449 \\
\hline wR2 (all data) ${ }^{b}$ & 0.1329 & 0.0725 & 0.0902 \\
\hline
\end{tabular}




\section{Computational Details.}

\section{4-1. Methods.}

Geometry optimizations were performed with the B3PW91 hybrid functional ${ }^{8,9}$ using Gaussian $09^{10}$ without any symmetry constraints in the gas phase. Ruthenium atoms were described with the SDD effective core potentials and the associated basis sets, ${ }^{11}$ while the 6$31 \mathrm{G}(\mathrm{d})$ basis set was applied for carbon, hydrogen, and nitrogen atoms. The optimized geometries were checked by frequency calculations to confirm all positive frequencies for minima and one negative frequency for transition states. To evaluate better the potential energy, single-point calculations were performed with inclusion of polarizable continuum model (PCM) ${ }^{12}$ solvent effects (THF) using the B3PW91-D3 functional, where D3 denotes the Grimme's third generation dispersion correction, ${ }^{13}$ and applying the larger $6-311+\mathrm{G}(\mathrm{d}, \mathrm{p})$ basis set for carbon, hydrogen, and nitrogen atoms. The Gibbs free energy was evaluated at 298.15 $\mathrm{K}$ and $1 \mathrm{~atm}$.

\section{4-2. Optimized geometries and atomic coordinates.}

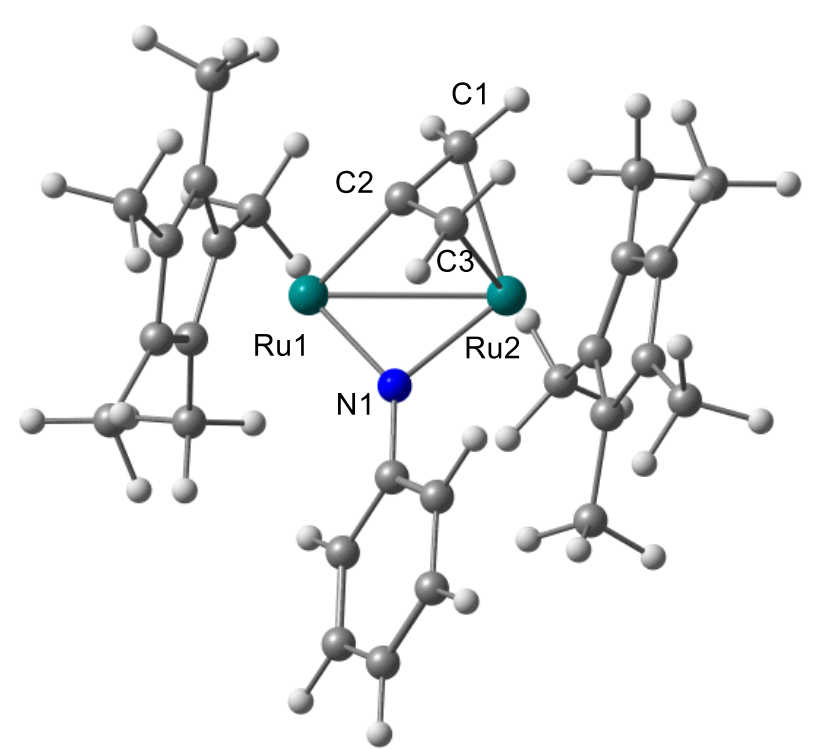

3

\section{Selected distances (A)}

Ru1-Ru2 2.76985

Ru1 - C2 2.03863

Ru1 - N1 1.85440

Ru2 - C1 2.18142

Ru2 - C2 2.08122

Ru2 - C3 2.21731

Ru2 - N1 2.04929

C1 - C2 1.42296

C2 - C3 1.42982

$\begin{array}{lrrr}44 & -1.420687000 & -0.242961000 & -0.192077000 \\ 44 & 1.331136000 & -0.546388000 & -0.278381000 \\ 7 & -0.029750000 & 0.983455000 & -0.193760000 \\ 6 & -3.156696000 & -1.712880000 & -0.338004000 \\ 6 & -2.900850000 & -1.465530000 & 1.036641000 \\ 6 & -3.104209000 & -0.053790000 & 1.286094000 \\ 6 & -3.452576000 & 0.575475000 & 0.050489000 \\ 6 & -3.438271000 & -0.452068000 & -0.977470000\end{array}$




\begin{tabular}{|c|c|c|c|}
\hline 6 & -3.154205000 & -3.047724000 & -1.017612000 \\
\hline 1 & -4.169389000 & -3.467182000 & -1.052705000 \\
\hline 1 & -2.519769000 & -3.769371000 & -0.494405000 \\
\hline 1 & -2.787900000 & -2.975451000 & -2.045937000 \\
\hline 6 & -2.596051000 & -2.490435000 & 2.084884000 \\
\hline 1 & -3.515202000 & -2.834112000 & 2.581445000 \\
\hline 1 & -1.934743000 & -2.086760000 & 2.857556000 \\
\hline 1 & -2.105927000 & -3.370716000 & 1.657280000 \\
\hline 6 & -3.083337000 & 0.583149000 & 2.642406000 \\
\hline 1 & -2.986163000 & 1.670770000 & 2.575797000 \\
\hline 1 & -2.253735000 & 0.210432000 & 3.252072000 \\
\hline 1 & -4.014103000 & 0.371188000 & 3.188578000 \\
\hline 6 & -3.896786000 & 1.992281000 & -0.146904000 \\
\hline 1 & -4.985288000 & 2.085388000 & -0.022023000 \\
\hline 1 & -3.646688000 & 2.351164000 & -1.149935000 \\
\hline 1 & -3.420150000 & 2.672702000 & 0.565103000 \\
\hline 6 & -3.865144000 & -0.268132000 & -2.401534000 \\
\hline 1 & -3.386364000 & -1.000144000 & -3.058797000 \\
\hline 1 & -3.599894000 & 0.726894000 & -2.771579000 \\
\hline 1 & -4.953849000 & -0.384357000 & -2.506953000 \\
\hline 6 & 3.435908000 & 0.164200000 & -0.241025000 \\
\hline 6 & 3.405420000 & -1.268937000 & -0.402386000 \\
\hline 6 & 2.831299000 & -1.831720000 & 0.797731000 \\
\hline 6 & 2.484970000 & -0.762840000 & 1.681477000 \\
\hline 6 & 2.857449000 & 0.466282000 & 1.038937000 \\
\hline 6 & 4.111353000 & 1.134012000 & -1.161099000 \\
\hline 1 & 3.680446000 & 2.135354000 & -1.077159000 \\
\hline 1 & 4.024791000 & 0.821812000 & -2.206441000 \\
\hline 1 & 5.182562000 & 1.211884000 & -0.925735000 \\
\hline 6 & 4.037860000 & -2.036861000 & -1.520923000 \\
\hline 1 & 5.088703000 & -2.270277000 & -1.298106000 \\
\hline 1 & 4.015627000 & -1.467569000 & -2.455254000 \\
\hline 1 & 3.524801000 & -2.986903000 & -1.703371000 \\
\hline 6 & 2.751261000 & -3.289425000 & 1.132751000 \\
\hline 1 & 2.690106000 & -3.912336000 & 0.236211000 \\
\hline 1 & 1.881032000 & -3.514238000 & 1.756361000 \\
\hline 1 & 3.647281000 & -3.599270000 & 1.688559000 \\
\hline 6 & 1.944033000 & -0.898697000 & 3.070450000 \\
\hline 1 & 2.758920000 & -0.949401000 & 3.807634000 \\
\hline 1 & 1.342733000 & -1.806069000 & 3.180026000 \\
\hline 1 & 1.310425000 & -0.047913000 & 3.336957000 \\
\hline 6 & 2.794382000 & 1.816022000 & 1.681578000 \\
\hline 1 & 3.681374000 & 1.968946000 & 2.312245000 \\
\hline
\end{tabular}




$\begin{array}{rrrr}1 & 1.910813000 & 1.921437000 & 2.317269000 \\ 1 & 2.763088000 & 2.621780000 & 0.944889000 \\ 6 & -0.213228000 & -1.284197000 & -1.462469000 \\ 6 & 0.432619000 & -2.428803000 & -0.916955000 \\ 1 & 1.168641000 & -2.972210000 & -1.518548000 \\ 1 & -0.067421000 & -3.024841000 & -0.157638000 \\ 6 & 0.617463000 & -0.565266000 & -2.377609000 \\ 1 & 1.279876000 & -1.129878000 & -3.041588000 \\ 1 & 0.295887000 & 0.397424000 & -2.762829000 \\ 6 & 0.128332000 & 2.359048000 & -0.152506000 \\ 6 & 0.890281000 & 3.029820000 & -1.131069000 \\ 6 & -0.488240000 & 3.129303000 & 0.851797000 \\ 6 & 1.015164000 & 4.415174000 & -1.106337000 \\ 1 & 1.360979000 & 2.441651000 & -1.913288000 \\ 6 & -0.346496000 & 4.514132000 & 0.874928000 \\ 1 & -1.062206000 & 2.612262000 & 1.614843000 \\ 6 & 0.402982000 & 5.169518000 & -0.102543000 \\ 1 & 1.596285000 & 4.911646000 & -1.880672000 \\ 1 & -0.824371000 & 5.085985000 & 1.667646000 \\ 1 & 0.509162000 & 6.250789000 & -0.083352000\end{array}$

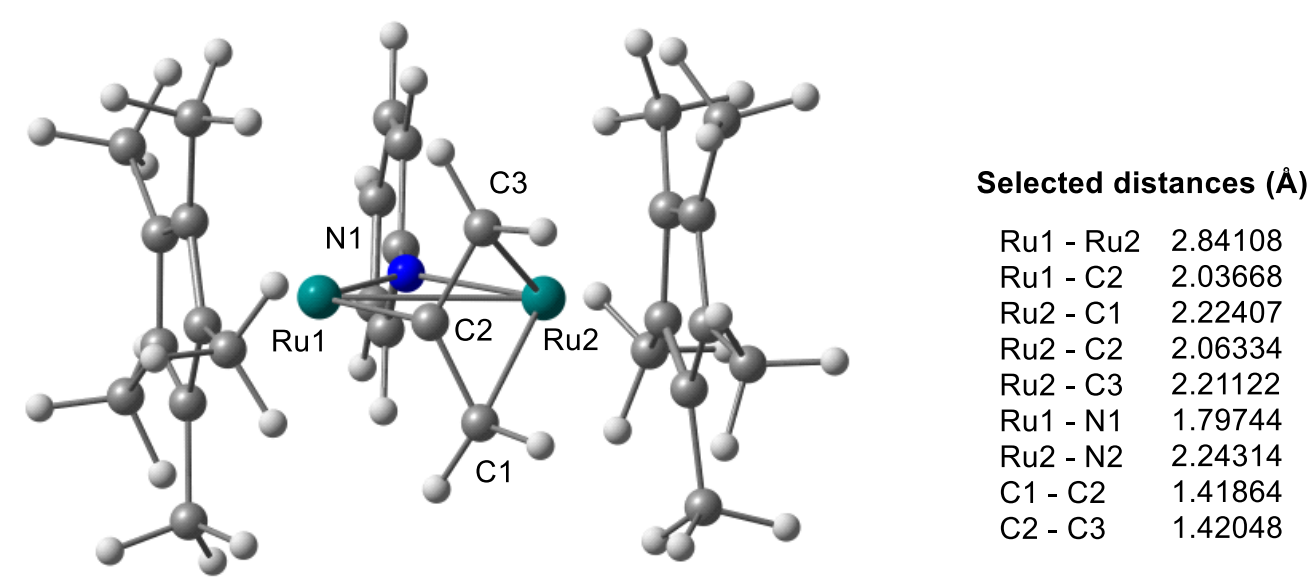

TS-flip-3

$\begin{array}{lrrr}44 & -1.443060000 & -0.272521000 & -0.001321000 \\ 44 & 1.370224000 & -0.668917000 & 0.006051000 \\ 7 & -0.152279000 & 0.978334000 & -0.008512000 \\ 6 & -0.261706000 & -1.931420000 & 0.021808000 \\ 6 & -0.026435000 & 2.358194000 & -0.002565000 \\ 6 & -0.104853000 & 3.087176000 & -1.205057000 \\ 1 & -0.206336000 & 2.535394000 & -2.135551000 \\ 6 & -0.056885000 & 4.478480000 & -1.194252000 \\ 1 & -0.121128000 & 5.025294000 & -2.132329000 \\ 6 & 0.074342000 & 5.172598000 & 0.010266000\end{array}$




\begin{tabular}{|c|c|c|c|}
\hline 1 & 0.113688000 & 6.258722000 & 0.015500000 \\
\hline 6 & 0.149319000 & 4.459761000 & 1.208779000 \\
\hline 1 & 0.242120000 & 4.992093000 & 2.152771000 \\
\hline 6 & 0.099119000 & 3.068083000 & 1.206747000 \\
\hline 1 & 0.142748000 & 2.502538000 & 2.133055000 \\
\hline 6 & 0.363044000 & -2.174588000 & 1.274138000 \\
\hline 6 & 0.346305000 & -2.208832000 & -1.229554000 \\
\hline 1 & 0.992052000 & -3.084532000 & -1.340172000 \\
\hline 1 & 1.006965000 & -3.050639000 & 1.399793000 \\
\hline 1 & -0.132572000 & -1.843577000 & 2.183023000 \\
\hline 1 & -0.157559000 & -1.896042000 & -2.140271000 \\
\hline 6 & -3.158771000 & -1.847483000 & 0.028410000 \\
\hline 6 & -3.225612000 & -1.038232000 & -1.147148000 \\
\hline 6 & -3.399793000 & 0.337917000 & -0.724482000 \\
\hline 6 & -3.394720000 & 0.360978000 & 0.714104000 \\
\hline 6 & -3.214243000 & -1.000818000 & 1.178440000 \\
\hline 6 & -3.047271000 & -3.340500000 & 0.051704000 \\
\hline 1 & -4.046244000 & -3.797684000 & 0.063719000 \\
\hline 1 & -2.507844000 & -3.691016000 & 0.936200000 \\
\hline 1 & -2.516222000 & -3.719256000 & -0.826210000 \\
\hline 6 & -3.271524000 & -1.532333000 & -2.559395000 \\
\hline 1 & -2.700207000 & -2.457824000 & -2.677738000 \\
\hline 1 & -2.854966000 & -0.797234000 & -3.255136000 \\
\hline 1 & -4.305043000 & -1.737927000 & -2.874258000 \\
\hline 6 & -3.660797000 & 1.503038000 & -1.629141000 \\
\hline 1 & -4.739990000 & 1.646420000 & -1.781873000 \\
\hline 1 & -3.203867000 & 1.352334000 & -2.611760000 \\
\hline 1 & -3.254722000 & 2.432108000 & -1.217945000 \\
\hline 6 & -3.656525000 & 1.552594000 & 1.583205000 \\
\hline 1 & -3.300427000 & 2.476671000 & 1.118349000 \\
\hline 1 & -3.156280000 & 1.458607000 & 2.551798000 \\
\hline 1 & -4.733163000 & 1.667032000 & 1.774040000 \\
\hline 6 & -3.246148000 & -1.447573000 & 2.606737000 \\
\hline 1 & -2.674554000 & -2.369267000 & 2.750476000 \\
\hline 1 & -4.276516000 & -1.640730000 & 2.939292000 \\
\hline 1 & -2.821268000 & -0.689366000 & 3.271948000 \\
\hline 6 & 3.257962000 & -0.569459000 & -1.233538000 \\
\hline 6 & 3.336854000 & -1.563923000 & -0.180381000 \\
\hline 6 & 3.292687000 & -0.874112000 & 1.088912000 \\
\hline 6 & 3.121281000 & 0.514706000 & 0.834201000 \\
\hline 6 & 3.102700000 & 0.694961000 & -0.617221000 \\
\hline 6 & 3.414793000 & -0.831224000 & -2.699305000 \\
\hline 1 & 4.477441000 & -0.843421000 & -2.982958000 \\
\hline
\end{tabular}




$\begin{array}{cccc}1 & 2.920591000 & -0.060425000 & -3.297855000 \\ 1 & 2.984933000 & -1.795451000 & -2.985875000 \\ 6 & 3.646354000 & -3.016474000 & -0.372025000 \\ 1 & 3.172546000 & -3.639913000 & 0.394260000 \\ 1 & 4.729147000 & -3.197935000 & -0.318248000 \\ 1 & 3.304774000 & -3.376827000 & -1.347474000 \\ 6 & 3.513415000 & -1.497558000 & 2.432185000 \\ 1 & 4.579440000 & -1.466064000 & 2.699501000 \\ 1 & 3.201775000 & -2.545690000 & 2.449807000 \\ 1 & 2.955663000 & -0.972617000 & 3.213116000 \\ 6 & 3.209650000 & 1.612717000 & 1.846432000 \\ 1 & 2.847941000 & 1.284569000 & 2.826176000 \\ 1 & 2.622299000 & 2.486472000 & 1.552637000 \\ 1 & 4.251056000 & 1.946103000 & 1.973820000 \\ 6 & 3.129082000 & 2.018398000 & -1.313149000 \\ 1 & 2.563467000 & 2.779759000 & -0.771681000 \\ 1 & 2.715805000 & 1.956903000 & -2.324374000 \\ 1 & 4.165469000 & 2.376925000 & -1.399261000\end{array}$

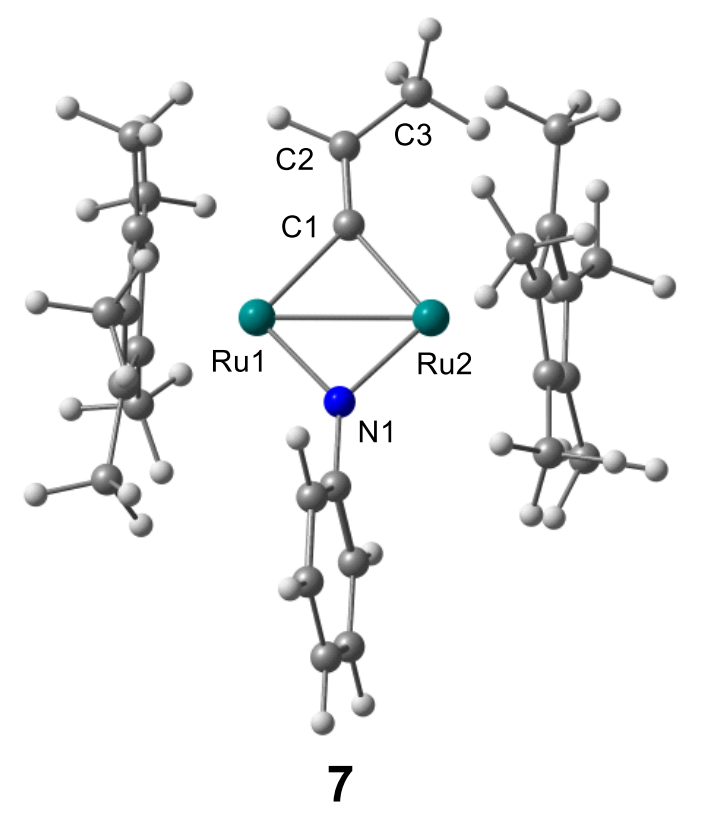

Selected distances (A)

Ru1-Ru2 2.64226

Ru1 - C1 2.04432

Ru1 - N1 1.90302

Ru2 - C1 2.04470

Ru2 - N1 1.91674

C1 - C2 1.34124

C2 - C3 1.50895

$\begin{array}{lrrr}44 & -1.311767000 & -0.275170000 & -0.043866000 \\ 44 & 1.327932000 & -0.387345000 & -0.012786000 \\ 7 & 0.077077000 & 1.045408000 & -0.076501000 \\ 6 & 0.140761000 & 2.440601000 & -0.087653000 \\ 6 & -0.017176000 & 3.150664000 & -1.293261000 \\ 1 & -0.187181000 & 2.588659000 & -2.207131000 \\ 6 & 0.052444000 & 4.543740000 & -1.306730000\end{array}$




\begin{tabular}{|c|c|c|c|}
\hline 1 & -0.067904000 & 5.076216000 & -2.247089000 \\
\hline 6 & 0.275016000 & 5.255500000 & -0.124051000 \\
\hline 1 & 0.326232000 & 6.340531000 & -0.138044000 \\
\hline 6 & 0.431874000 & 4.556637000 & 1.076400000 \\
\hline 1 & 0.604781000 & 5.099329000 & 2.002633000 \\
\hline 6 & 0.369189000 & 3.163105000 & 1.099023000 \\
\hline 1 & 0.489286000 & 2.613036000 & 2.028037000 \\
\hline 6 & -0.057368000 & -1.889671000 & -0.069551000 \\
\hline 6 & 0.017154000 & -3.227734000 & -0.124006000 \\
\hline 1 & 0.998075000 & -3.670110000 & 0.043435000 \\
\hline 6 & -1.040357000 & -4.249734000 & -0.461824000 \\
\hline 1 & -1.329074000 & -4.866605000 & 0.402322000 \\
\hline 1 & -1.939968000 & -3.782356000 & -0.859464000 \\
\hline 1 & -0.664476000 & -4.943334000 & -1.227728000 \\
\hline 6 & -3.206977000 & -1.362131000 & 0.612318000 \\
\hline 6 & -3.050650000 & -0.126539000 & 1.331977000 \\
\hline 6 & -3.148297000 & 0.961522000 & 0.389532000 \\
\hline 6 & -3.252332000 & 0.394929000 & -0.917455000 \\
\hline 6 & -3.298309000 & -1.049085000 & -0.785799000 \\
\hline 6 & -3.388260000 & -2.693685000 & 1.288961000 \\
\hline 1 & -4.216037000 & -2.639614000 & 2.008671000 \\
\hline 1 & -2.491438000 & -3.006030000 & 1.833498000 \\
\hline 1 & -3.628678000 & -3.482226000 & 0.573292000 \\
\hline 6 & -2.979898000 & -0.001051000 & 2.826430000 \\
\hline 1 & -3.987806000 & 0.015800000 & 3.267312000 \\
\hline 1 & -2.471796000 & 0.919695000 & 3.127883000 \\
\hline 1 & -2.436546000 & -0.842200000 & 3.266738000 \\
\hline 6 & -3.182130000 & 2.421630000 & 0.737476000 \\
\hline 1 & -2.836159000 & 3.045928000 & -0.090690000 \\
\hline 1 & -2.550032000 & 2.649442000 & 1.600750000 \\
\hline 1 & -4.207054000 & 2.732186000 & 0.985038000 \\
\hline 6 & -3.427368000 & 1.142540000 & -2.208384000 \\
\hline 1 & -4.493675000 & 1.279410000 & -2.440621000 \\
\hline 1 & -2.974074000 & 0.598788000 & -3.042998000 \\
\hline 1 & -2.967457000 & 2.134039000 & -2.165079000 \\
\hline 6 & -3.635894000 & -1.970690000 & -1.926459000 \\
\hline 1 & -3.676204000 & -3.014824000 & -1.608389000 \\
\hline 1 & -2.906070000 & -1.901987000 & -2.739951000 \\
\hline 1 & -4.621656000 & -1.719287000 & -2.342611000 \\
\hline 6 & 3.248341000 & -0.454616000 & -1.166461000 \\
\hline 6 & 3.111189000 & -1.726062000 & -0.511557000 \\
\hline 6 & 3.051265000 & -1.492026000 & 0.902756000 \\
\hline 6 & 3.209918000 & -0.067690000 & 1.121582000 \\
\hline
\end{tabular}




$\begin{array}{rrrr}6 & 3.365228000 & 0.564578000 & -0.156279000 \\ 6 & 3.407919000 & -0.262835000 & -2.647048000 \\ 1 & 3.081684000 & 0.732241000 & -2.963094000 \\ 1 & 2.823930000 & -1.000564000 & -3.205323000 \\ 1 & 4.461146000 & -0.376122000 & -2.943914000 \\ 6 & 3.166152000 & -3.051335000 & -1.219367000 \\ 1 & 4.101033000 & -3.136789000 & -1.789053000 \\ 1 & 2.332763000 & -3.184363000 & -1.917615000 \\ 1 & 3.142085000 & -3.884973000 & -0.512601000 \\ 6 & 2.995870000 & -2.537270000 & 1.980233000 \\ 1 & 2.312160000 & -3.350981000 & 1.721785000 \\ 1 & 2.646644000 & -2.110676000 & 2.925029000 \\ 1 & 3.988641000 & -2.974360000 & 2.160069000 \\ 6 & 3.333967000 & 0.602955000 & 2.459914000 \\ 1 & 4.370462000 & 0.556877000 & 2.824590000 \\ 1 & 2.697630000 & 0.123179000 & 3.209469000 \\ 1 & 3.049784000 & 1.657818000 & 2.406319000 \\ 6 & 3.643691000 & 2.020011000 & -0.404271000 \\ 1 & 4.726077000 & 2.209301000 & -0.435805000 \\ 1 & 3.218198000 & 2.656305000 & 0.377064000 \\ 1 & 3.222078000 & 2.353896000 & -1.357192000\end{array}$

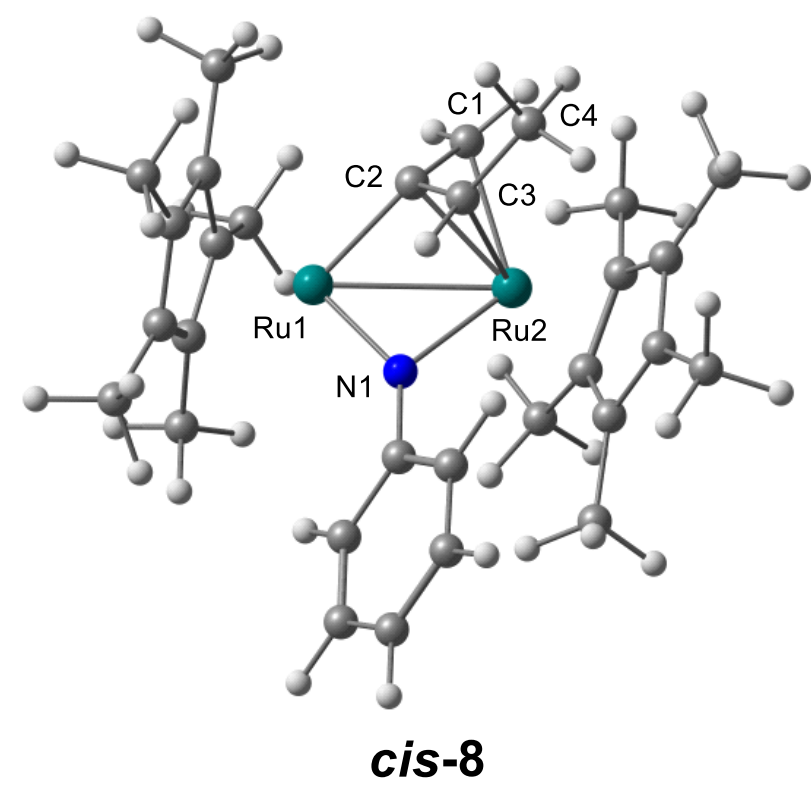

Selected distances (Â)

Ru1-Ru2 2.76006

Ru1 - C2 2.04640

Ru1 - N1 1.85311

Ru2 - C1 2.17874

Ru2 - C2 2.07654

Ru2 - C3 2.26519

Ru2 - N1 2.05543

C1 - C2 1.42284

C2 - C3 1.43279

C3 - C4 1.51044

$\begin{array}{lrrr}44 & 1.308054000 & -0.506663000 & -0.130691000 \\ 44 & -1.438857000 & -0.237579000 & -0.129926000 \\ 7 & -0.073464000 & 1.015064000 & -0.154247000 \\ 6 & 0.454852000 & -2.427206000 & -0.705570000 \\ 6 & -0.180985000 & -1.317706000 & -1.329433000 \\ 6 & 0.612114000 & -0.601972000 & -2.284212000\end{array}$




\begin{tabular}{|c|c|c|c|}
\hline 6 & 1.458531000 & -1.253669000 & -3.352054000 \\
\hline 6 & 0.066022000 & 2.391855000 & -0.186798000 \\
\hline 6 & 0.865474000 & 3.016219000 & -1.166437000 \\
\hline 6 & 0.967290000 & 4.402454000 & -1.221684000 \\
\hline 6 & 0.296364000 & 5.204969000 & -0.295726000 \\
\hline 6 & -0.486806000 & 4.596438000 & 0.685801000 \\
\hline 6 & -0.606454000 & 3.210499000 & 0.740797000 \\
\hline 6 & 2.336728000 & -0.495340000 & 1.895570000 \\
\hline 6 & 2.694477000 & -1.673661000 & 1.169930000 \\
\hline 6 & 3.368953000 & -1.275229000 & -0.047221000 \\
\hline 6 & 3.440553000 & 0.164619000 & -0.053618000 \\
\hline 6 & 2.800994000 & 0.635105000 & 1.139671000 \\
\hline 6 & 1.706105000 & -0.444106000 & 3.251857000 \\
\hline 6 & 2.542933000 & -3.076960000 & 1.671310000 \\
\hline 6 & 4.082854000 & -2.192714000 & -0.990315000 \\
\hline 6 & 4.192120000 & 1.000742000 & -1.043472000 \\
\hline 6 & 2.759774000 & 2.052006000 & 1.618260000 \\
\hline 6 & -3.146134000 & -1.744574000 & -0.297938000 \\
\hline 6 & -3.429275000 & -0.504378000 & -0.974822000 \\
\hline 6 & -3.488672000 & 0.546848000 & 0.025903000 \\
\hline 6 & -3.163256000 & -0.047663000 & 1.286298000 \\
\hline 6 & -2.935467000 & -1.462458000 & 1.077531000 \\
\hline 6 & -3.102426000 & -3.094153000 & -0.946415000 \\
\hline 6 & -3.819343000 & -0.360487000 & -2.414012000 \\
\hline 6 & -3.955356000 & 1.949002000 & -0.217728000 \\
\hline 6 & -3.188826000 & 0.622754000 & 2.626343000 \\
\hline 6 & -2.652269000 & -2.457852000 & 2.159522000 \\
\hline 1 & -3.583110000 & -2.806190000 & 2.630500000 \\
\hline 1 & -2.027075000 & -2.024908000 & 2.946440000 \\
\hline 1 & -2.132309000 & -3.339411000 & 1.771756000 \\
\hline 1 & 2.285991000 & -0.598113000 & -3.651098000 \\
\hline 1 & -1.207382000 & 2.729450000 & 1.506912000 \\
\hline 1 & 1.386188000 & 2.388665000 & -1.884131000 \\
\hline 1 & 1.578107000 & 4.861720000 & -1.996200000 \\
\hline 1 & 0.384695000 & 6.287187000 & -0.338303000 \\
\hline 1 & -1.008954000 & 5.206616000 & 1.419867000 \\
\hline 1 & 3.777083000 & 2.009963000 & -1.114624000 \\
\hline 1 & 3.401640000 & -3.350715000 & 2.300434000 \\
\hline 1 & 1.638747000 & -3.193968000 & 2.276498000 \\
\hline 1 & 2.491557000 & -3.799589000 & 0.852220000 \\
\hline 1 & 5.088731000 & -2.432240000 & -0.616641000 \\
\hline 1 & 3.550767000 & -3.141500000 & -1.117532000 \\
\hline 1 & 4.197593000 & -1.742406000 & -1.980303000 \\
\hline
\end{tabular}




$\begin{array}{lrrr}1 & 4.165048000 & 0.559171000 & -2.044354000 \\ 1 & 2.470672000 & -0.454252000 & 4.042668000 \\ 1 & 1.109839000 & 0.463575000 & 3.381347000 \\ 1 & 1.045685000 & -1.300110000 & 3.417886000 \\ 1 & 3.608274000 & 2.236881000 & 2.292086000 \\ 1 & 2.822037000 & 2.768183000 & 0.796173000 \\ 1 & 1.842193000 & 2.271186000 & 2.170997000 \\ 1 & 5.248088000 & 1.095509000 & -0.752074000 \\ 1 & 1.884290000 & -2.212487000 & -3.043865000 \\ 1 & 0.225923000 & 0.369321000 & -2.584183000 \\ 1 & -2.468472000 & -3.792310000 & -0.391734000 \\ 1 & -2.711646000 & -3.038091000 & -1.966800000 \\ 1 & -4.108820000 & -3.532759000 & -0.997368000 \\ 1 & -3.309193000 & -1.097034000 & -3.042006000 \\ 1 & -4.902262000 & -0.501118000 & -2.546181000 \\ 1 & -3.564466000 & 0.631731000 & -2.798770000 \\ 1 & -3.673547000 & 2.295115000 & -1.216930000 \\ 1 & -5.049737000 & 2.020576000 & -0.137103000 \\ 1 & -3.522334000 & 2.652956000 & 0.498824000 \\ 1 & -3.090537000 & 1.708723000 & 2.536570000 \\ 1 & -4.136863000 & 0.422294000 & 3.146670000 \\ 1 & -2.378754000 & 0.267582000 & 3.271609000 \\ 1 & 1.214834000 & -3.012273000 & -1.230047000 \\ 1 & -0.076602000 & -2.978425000 & 0.065928000 \\ 1 & 0.858426000 & -1.437613000 & -4.256310000\end{array}$

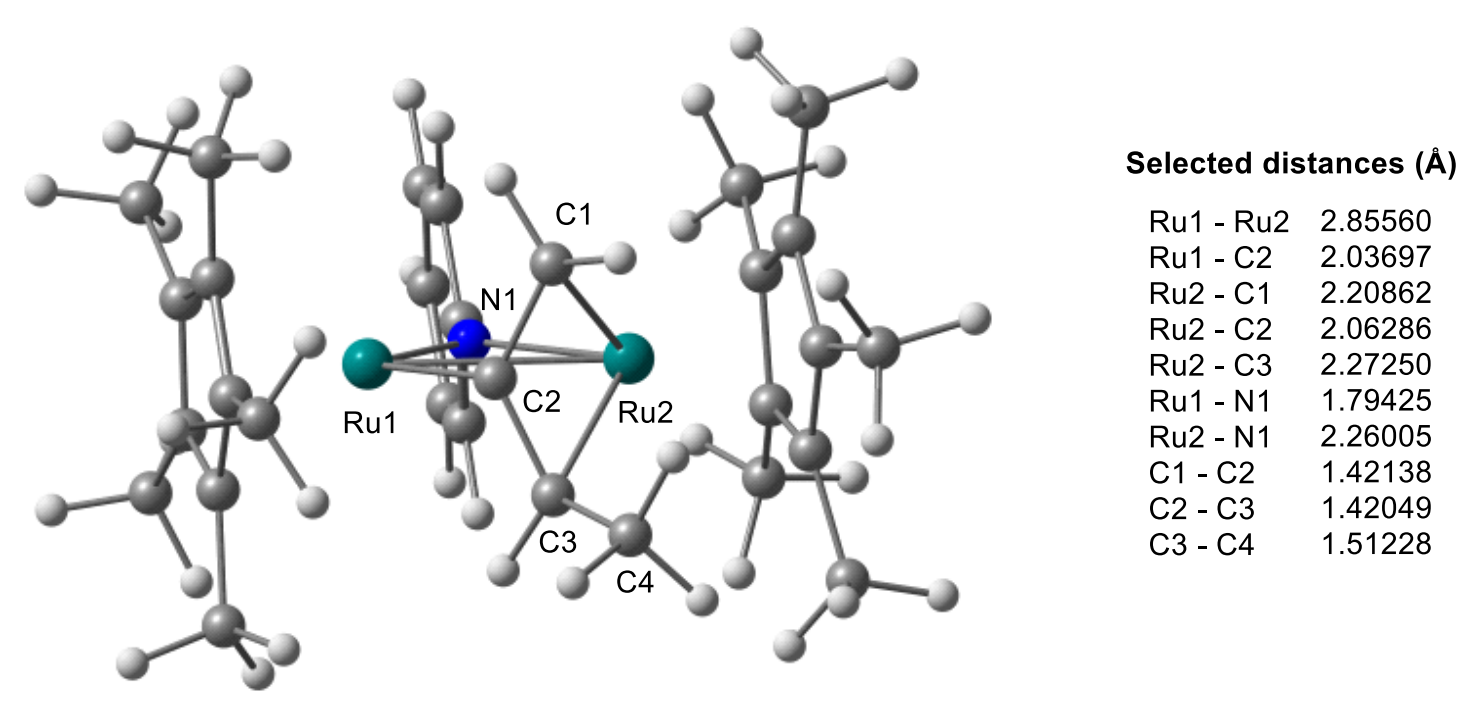

TS-flip-cis-8 


$\begin{array}{lrrr}44 & -1.449013000 & -0.286916000 & 0.038716000 \\ 44 & 1.398057000 & -0.506223000 & 0.061547000 \\ 7 & -0.245737000 & 1.043041000 & -0.012911000 \\ 6 & -0.157544000 & -1.857095000 & 0.164704000 \\ 6 & -0.241912000 & 2.427488000 & -0.087281000 \\ 6 & -0.186883000 & 3.081454000 & -1.333101000 \\ 1 & -0.090413000 & 2.474456000 & -2.228876000 \\ 6 & -0.273018000 & 4.469270000 & -1.408800000 \\ 1 & -0.232873000 & 4.957421000 & -2.379976000 \\ 6 & -0.416385000 & 5.233943000 & -0.249112000 \\ 1 & -0.482454000 & 6.316976000 & -0.311731000 \\ 6 & -0.480041000 & 4.595065000 & 0.991022000 \\ 1 & -0.598078000 & 5.181582000 & 1.899385000 \\ 6 & -0.392759000 & 3.208240000 & 1.075044000 \\ 1 & -0.443752000 & 2.699497000 & 2.033596000 \\ 6 & 0.473767000 & -1.969880000 & 1.433191000 \\ 1 & 1.168604000 & -2.788243000 & 1.643492000 \\ 1 & -0.047224000 & -1.589019000 & 2.308178000 \\ 6 & 0.432356000 & -2.220634000 & -1.075318000 \\ 1 & -0.103231000 & -1.887415000 & -1.963535000 \\ 6 & 1.185195000 & -3.516909000 & -1.275087000 \\ 1 & 1.644064000 & -3.878625000 & -0.350291000 \\ 1 & 0.498428000 & -4.304050000 & -1.622904000 \\ 1 & 1.969046000 & -3.429168000 & -2.035484000 \\ 6 & -3.063407000 & -1.973579000 & 0.066805000 \\ 6 & -3.165951000 & -1.190971000 & -1.121806000 \\ 6 & -3.431620000 & 0.178070000 & -0.725980000 \\ 6 & -3.448367000 & 0.226294000 & 0.712084000 \\ 6 & -3.185873000 & -1.112938000 & 1.202125000 \\ 6 & -2.855584000 & -3.455155000 & 0.119077000 \\ 1 & -3.822630000 & -3.976493000 & 0.134439000 \\ 1 & -2.300346000 & -3.753713000 & 1.012773000 \\ 1 & -2.296844000 & -3.815273000 & -0.749371000 \\ 1 & -3.161138000 & -1.704940000 & -2.527662000 \\ 1 & -2.564890000 & -2.617530000 & -2.619409000 \\ 1 & -2.744805000 & -0.968226000 & -3.222025000 \\ 1 & -4.180560000 & -1.940469000 & -2.866422000 \\ 1 & -3.751756000 & 1.309232000 & -1.654599000 \\ 1 & -4.835366000 & 1.379981000 & -1.826265000 \\ 1 & -3.470278000 & 1.172942000 & -2.627583000 \\ 1 & & 2.269839000 & -1.253869000 \\ 1 & & 1.414097000 & 1.554065000 \\ 1 & 2.348572000 & 1.088263000\end{array}$




$\begin{array}{lrrr}1 & -3.327469000 & 1.355983000 & 2.539614000 \\ 1 & -4.885876000 & 1.477733000 & 1.707595000 \\ 6 & -3.212962000 & -1.542038000 & 2.635968000 \\ 1 & -2.565058000 & -2.407032000 & 2.806641000 \\ 1 & -4.229941000 & -1.821730000 & 2.947655000 \\ 1 & -2.873156000 & -0.740889000 & 3.299594000 \\ 6 & 3.369157000 & -0.512511000 & -1.011073000 \\ 6 & 3.461340000 & -1.180705000 & 0.270283000 \\ 6 & 3.244664000 & -0.189560000 & 1.304116000 \\ 6 & 2.965198000 & 1.044037000 & 0.671514000 \\ 6 & 3.034139000 & 0.845332000 & -0.776446000 \\ 6 & 3.719858000 & -1.096931000 & -2.343731000 \\ 1 & 4.770446000 & -0.884419000 & -2.588810000 \\ 1 & 3.099768000 & -0.678701000 & -3.142128000 \\ 1 & 3.596260000 & -2.182421000 & -2.360743000 \\ 6 & 3.996495000 & -2.557541000 & 0.519458000 \\ 1 & 3.466533000 & -3.063828000 & 1.334079000 \\ 1 & 5.057286000 & -2.510253000 & 0.804436000 \\ 1 & 3.922904000 & -3.191129000 & -0.367912000 \\ 6 & 3.402574000 & -0.419031000 & 2.775080000 \\ 1 & 4.449699000 & -0.278163000 & 3.081286000 \\ 1 & 3.109914000 & -1.434484000 & 3.057029000 \\ 1 & 2.789824000 & 0.275424000 & 3.357410000 \\ 6 & 2.854992000 & 2.367855000 & 1.357761000 \\ 1 & 2.383855000 & 2.279265000 & 2.341517000 \\ 1 & 2.275010000 & 3.088232000 & 0.777835000 \\ 1 & 3.856797000 & 2.797111000 & 1.508324000 \\ 6 & 3.019765000 & 1.932327000 & -1.804025000 \\ 1 & 2.343263000 & 2.745817000 & -1.530384000 \\ 1 & 2.706698000 & 1.556136000 & -2.783238000 \\ 1 & 4.023839000 & 2.367429000 & -1.922997000\end{array}$




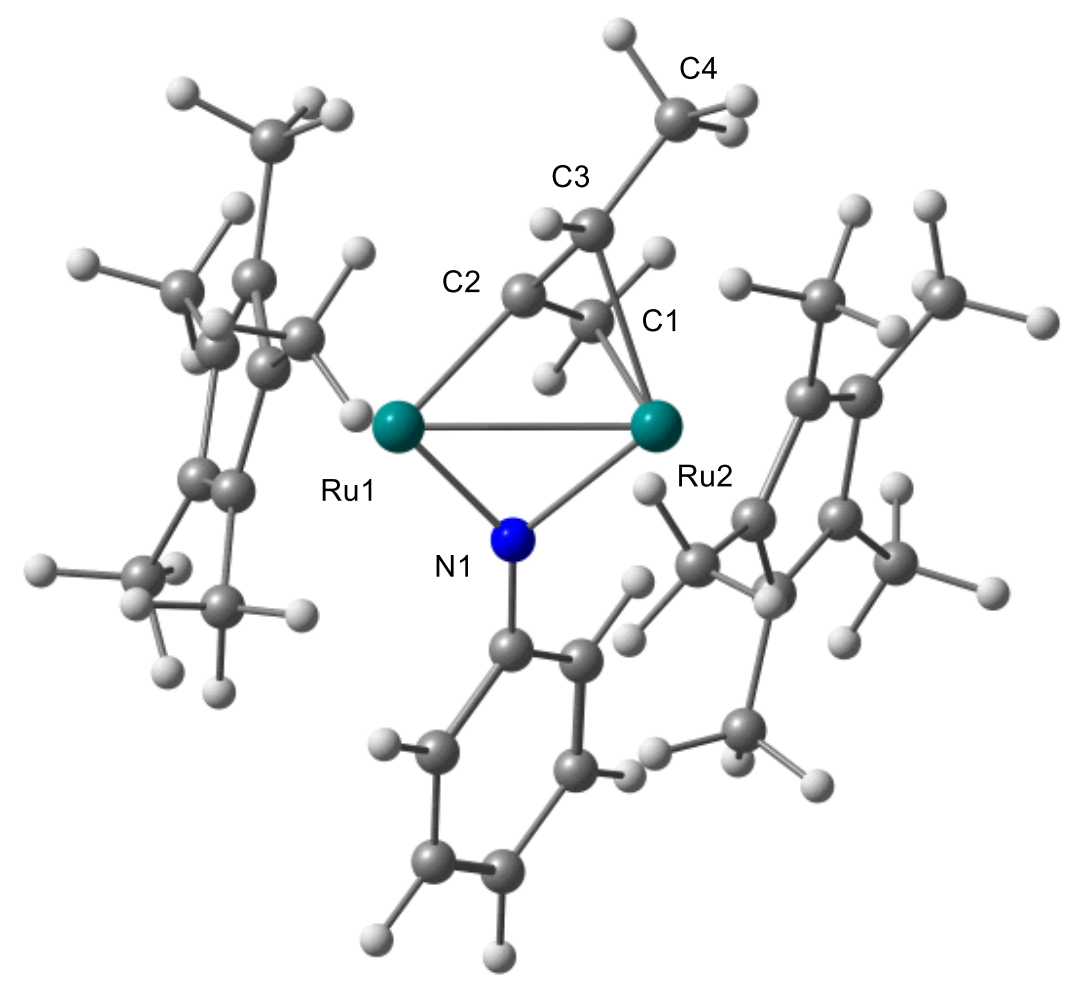

Selected distances (Â)

Ru1-Ru2 2.76137

Ru1 - C2 2.03650

Ru2 - C1 2.22216

Ru2 - C2 2.07205

Ru2 - C3 2.23869

Ru1 - N1 1.84954

Ru2 - N1 2.05953

C1 - C2 1.43261

C2 - C3 1.42622

C3 - C4 1.51298

\section{cis-8'}

$\begin{array}{lrrr}44 & 1.418424000 & -0.262589000 & -0.121735000 \\ 44 & -1.338308000 & -0.396411000 & -0.209378000 \\ 7 & 0.121505000 & 1.055519000 & -0.159210000 \\ 6 & 0.149573000 & -1.249696000 & -1.371917000 \\ 6 & 0.067239000 & 2.436480000 & -0.240139000 \\ 6 & 0.801283000 & 3.239502000 & 0.654495000 \\ 1 & 1.380241000 & 2.746497000 & 1.429751000 \\ 6 & 0.767580000 & 4.627398000 & 0.558220000 \\ 1 & 1.334947000 & 5.225134000 & 1.268551000 \\ 6 & 0.011596000 & 5.254429000 & -0.433204000 \\ 1 & -0.010719000 & 6.338317000 & -0.507228000 \\ 6 & -0.717596000 & 4.467775000 & -1.327800000 \\ 1 & -1.307149000 & 4.940363000 & -2.110696000 \\ 6 & -0.701210000 & 3.079845000 & -1.231867000 \\ 1 & -1.265958000 & 2.465100000 & -1.926084000 \\ 6 & -0.606348000 & -0.469962000 & -2.306239000 \\ 1 & -1.286811000 & -0.958821000 & -3.006607000 \\ 1 & -0.194293000 & 0.465973000 & -2.669723000 \\ 6 & -0.527760000 & -2.386005000 & -0.838877000 \\ 1 & -0.026002000 & -2.886133000 & -0.010487000 \\ 6 & -1.373914000 & -3.324541000 & -1.670920000 \\ 1 & -1.975919000 & -2.811921000 & -2.424189000 \\ 1 & -0.711097000 & -4.026025000 & -2.200303000\end{array}$




\begin{tabular}{|c|c|c|c|}
\hline 1 & -2.041504000 & -3.933356000 & -1.054098000 \\
\hline 6 & 3.050633000 & -1.853147000 & -0.280647000 \\
\hline 6 & 2.855675000 & -1.560724000 & 1.094328000 \\
\hline 6 & 3.155861000 & -0.159728000 & 1.303298000 \\
\hline 6 & 3.509214000 & 0.418132000 & 0.044142000 \\
\hline 6 & 3.392926000 & -0.627006000 & -0.957980000 \\
\hline 6 & 2.940936000 & -3.198777000 & -0.929331000 \\
\hline 1 & 3.924664000 & -3.685932000 & -0.981555000 \\
\hline 1 & 2.553323000 & -3.123233000 & -1.949856000 \\
\hline 1 & 2.274225000 & -3.865986000 & -0.374564000 \\
\hline 6 & 2.523884000 & -2.538770000 & 2.178279000 \\
\hline 1 & 1.975180000 & -3.401674000 & 1.789035000 \\
\hline 1 & 1.907860000 & -2.078850000 & 2.957226000 \\
\hline 1 & 3.436339000 & -2.919592000 & 2.659942000 \\
\hline 6 & 3.208398000 & 0.506206000 & 2.644885000 \\
\hline 1 & 4.130698000 & 0.236552000 & 3.179746000 \\
\hline 1 & 2.364502000 & 0.210333000 & 3.276775000 \\
\hline 1 & 3.190639000 & 1.596555000 & 2.556715000 \\
\hline 6 & 4.046659000 & 1.793249000 & -0.206229000 \\
\hline 1 & 3.731625000 & 2.500161000 & 0.566268000 \\
\hline 1 & 3.698599000 & 2.189774000 & -1.165040000 \\
\hline 1 & 5.146062000 & 1.788732000 & -0.225329000 \\
\hline 6 & 3.790765000 & -0.498459000 & -2.396437000 \\
\hline 1 & 3.244573000 & -1.205835000 & -3.027469000 \\
\hline 1 & 4.865474000 & -0.691973000 & -2.528670000 \\
\hline 1 & 3.585091000 & 0.506818000 & -2.776464000 \\
\hline 6 & -2.921110000 & -1.488577000 & 0.980442000 \\
\hline 6 & -3.495563000 & -0.895852000 & -0.206518000 \\
\hline 6 & -3.358673000 & 0.535040000 & -0.087283000 \\
\hline 6 & -2.683337000 & 0.802633000 & 1.150195000 \\
\hline 6 & -2.407792000 & -0.443968000 & 1.806883000 \\
\hline 6 & -3.007895000 & -2.923596000 & 1.403854000 \\
\hline 1 & -3.766648000 & -3.032936000 & 2.191078000 \\
\hline 1 & -2.059245000 & -3.291058000 & 1.808486000 \\
\hline 1 & -3.300031000 & -3.578988000 & 0.580790000 \\
\hline 6 & -4.337775000 & -1.583399000 & -1.237474000 \\
\hline 1 & -4.177704000 & -1.160150000 & -2.234522000 \\
\hline 1 & -5.405728000 & -1.472282000 & -1.000293000 \\
\hline 1 & -4.124864000 & -2.653406000 & -1.295081000 \\
\hline 6 & -3.997385000 & 1.541824000 & -0.993742000 \\
\hline 1 & -5.051998000 & 1.693951000 & -0.721447000 \\
\hline 1 & -3.971043000 & 1.215296000 & -2.038141000 \\
\hline 1 & -3.498040000 & 2.512574000 & -0.936046000 \\
\hline
\end{tabular}




$\begin{array}{lrrr}6 & -2.444583000 & 2.149396000 & 1.756483000 \\ 1 & -2.411519000 & 2.940842000 & 1.004944000 \\ 1 & -1.501766000 & 2.185051000 & 2.309493000 \\ 1 & -3.254658000 & 2.385076000 & 2.460864000 \\ 6 & -1.819939000 & -0.613478000 & 3.173011000 \\ 1 & -1.138957000 & 0.205373000 & 3.421252000 \\ 1 & -1.258001000 & -1.548890000 & 3.254363000 \\ 1 & -2.608086000 & -0.631431000 & 3.940612000\end{array}$

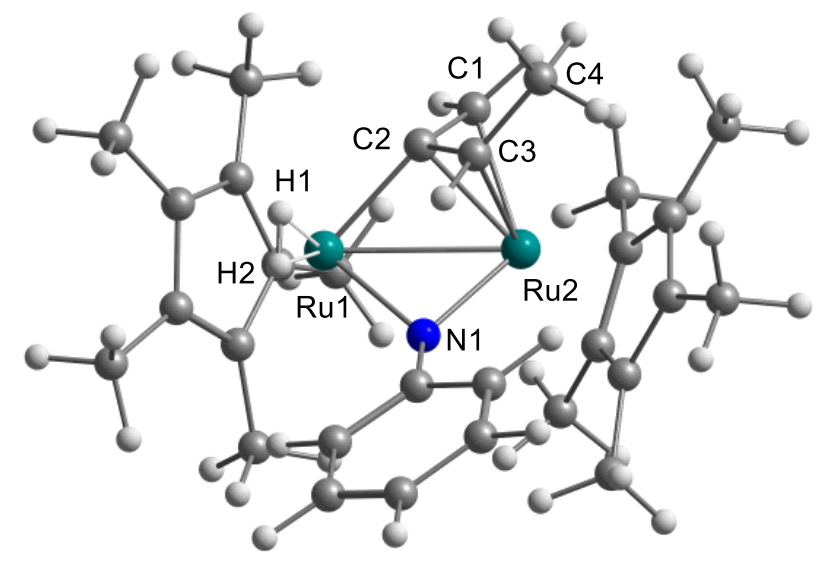

TS1

$\begin{array}{lrrr}44 & -1.277845000 & -0.402212000 & -0.192364000 \\ 44 & 1.476765000 & -0.171571000 & -0.354743000 \\ 6 & 0.083668000 & -0.798468000 & -1.714382000 \\ 6 & -0.761762000 & 0.217348000 & -2.277170000 \\ 6 & -0.587229000 & -2.030892000 & -1.447649000 \\ 6 & -2.246965000 & -0.895765000 & 1.837725000 \\ 6 & -2.706597000 & 0.392586000 & 1.409537000 \\ 6 & -3.400690000 & 0.243891000 & 0.166477000 \\ 6 & -3.342593000 & -1.148461000 & -0.198921000 \\ 6 & -2.631615000 & -1.851611000 & 0.847846000 \\ 6 & -1.637931000 & -1.174455000 & 3.174859000 \\ 6 & -2.557112000 & 1.641293000 & 2.219685000 \\ 6 & -4.228382000 & 1.279996000 & -0.529929000 \\ 6 & -4.119998000 & -1.785684000 & -1.308175000 \\ 6 & -2.500096000 & -3.338800000 & 0.961671000 \\ 6 & 2.797380000 & -0.448027000 & 1.462142000 \\ 6 & 2.273110000 & -1.719149000 & 0.997110000 \\ 6 & 2.817264000 & -1.976194000 & -0.308643000 \\ 6 & 3.554772000 & -0.824909000 & -0.703968000 \\ 6 & 3.579983000 & 0.108633000 & 0.420697000 \\ 6 & 2.587616000 & 0.113868000 & 2.833904000\end{array}$

Selected distances (Å)

Ru1 - Ru2 2.76901

Ru1 - C2 2.04508

Ru1 - N1 1.99463

Ru1 - H1 2.07873

Ru1 - H2 2.26248

Ru2 - C1 2.16917

Ru2 - C2 2.08021

Ru2 - C3 2.23531

Ru2 - N1 2.01875

C1 - C2 1.42833

C2 - C3 1.43644

C3 - C4 1.51010

$\mathrm{H} 1-\mathrm{H} 2 \quad 0.77151$ 


\begin{tabular}{|c|c|c|c|}
\hline 6 & 1.559076000 & -2.716536000 & 1.852794000 \\
\hline 6 & 2.712978000 & -3.252840000 & -1.084386000 \\
\hline 6 & 4.367090000 & -0.686625000 & -1.956480000 \\
\hline 6 & 4.431662000 & 1.340206000 & 0.478461000 \\
\hline 7 & 0.031697000 & 1.078340000 & 0.218021000 \\
\hline 6 & 0.044328000 & 2.429499000 & 0.110582000 \\
\hline 6 & 1.173648000 & 3.194409000 & 0.518239000 \\
\hline 6 & -1.039792000 & 3.165134000 & -0.445224000 \\
\hline 6 & 1.185788000 & 4.581840000 & 0.425014000 \\
\hline 6 & -1.004060000 & 4.550307000 & -0.542686000 \\
\hline 6 & 0.100461000 & 5.283842000 & -0.101279000 \\
\hline 1 & 1.952301000 & 1.735777000 & -1.474884000 \\
\hline 1 & 1.946214000 & 1.108440000 & -1.923920000 \\
\hline 1 & 1.562719000 & -0.050209000 & 3.177577000 \\
\hline 1 & 2.771646000 & 1.191133000 & 2.864300000 \\
\hline 1 & 3.263515000 & -0.363205000 & 3.557523000 \\
\hline 1 & 4.187792000 & 1.963129000 & 1.343350000 \\
\hline 1 & 4.322439000 & 1.960599000 & -0.416699000 \\
\hline 1 & 5.492600000 & 1.065979000 & 0.561352000 \\
\hline 1 & 4.461185000 & 0.358969000 & -2.264991000 \\
\hline 1 & 3.917164000 & -1.238820000 & -2.786824000 \\
\hline 1 & 5.383627000 & -1.077661000 & -1.806225000 \\
\hline 1 & 3.625292000 & -3.851423000 & -0.951624000 \\
\hline 1 & 2.586253000 & -3.072410000 & -2.156022000 \\
\hline 1 & 1.873377000 & -3.868620000 & -0.750885000 \\
\hline 1 & 0.925912000 & -3.381259000 & 1.258279000 \\
\hline 1 & 0.924663000 & -2.220848000 & 2.589647000 \\
\hline 1 & 2.281198000 & -3.343057000 & 2.396909000 \\
\hline 1 & -0.047287000 & -2.834286000 & -0.954508000 \\
\hline 1 & -1.402481000 & -2.375242000 & -2.087147000 \\
\hline 1 & -0.375970000 & 1.234908000 & -2.259686000 \\
\hline 1 & -1.628715000 & -3.622636000 & 1.558797000 \\
\hline 1 & -2.398662000 & -3.812362000 & -0.019150000 \\
\hline 1 & -3.388104000 & -3.768428000 & 1.446709000 \\
\hline 1 & -0.881840000 & -0.428696000 & 3.438283000 \\
\hline 1 & -2.409441000 & -1.145053000 & 3.958106000 \\
\hline 1 & -1.174878000 & -2.163473000 & 3.214676000 \\
\hline 1 & -1.541687000 & 1.732745000 & 2.616346000 \\
\hline 1 & -2.752895000 & 2.540311000 & 1.632520000 \\
\hline 1 & -3.254270000 & 1.625813000 & 3.069093000 \\
\hline 1 & -3.961146000 & 2.292162000 & -0.216743000 \\
\hline 1 & -5.292518000 & 1.134132000 & -0.296323000 \\
\hline 1 & -4.121546000 & 1.226706000 & -1.617691000 \\
\hline
\end{tabular}




$\begin{array}{lrrr}1 & -4.269432000 & -1.096516000 & -2.143846000 \\ 1 & -5.113358000 & -2.095465000 & -0.953178000 \\ 1 & -3.622380000 & -2.679931000 & -1.697078000 \\ 1 & -1.890106000 & 2.606171000 & -0.820487000 \\ 1 & -1.855029000 & 5.066974000 & -0.984535000 \\ 1 & 0.118829000 & 6.367330000 & -0.177214000 \\ 1 & 2.065772000 & 5.122552000 & 0.770332000 \\ 1 & 2.017438000 & 2.666811000 & 0.950831000 \\ 6 & -1.727981000 & -0.005942000 & -3.416018000 \\ 1 & -1.222384000 & 0.166358000 & -4.378164000 \\ 1 & -2.145385000 & -1.016097000 & -3.443991000 \\ 1 & -2.560876000 & 0.705800000 & -3.367277000\end{array}$

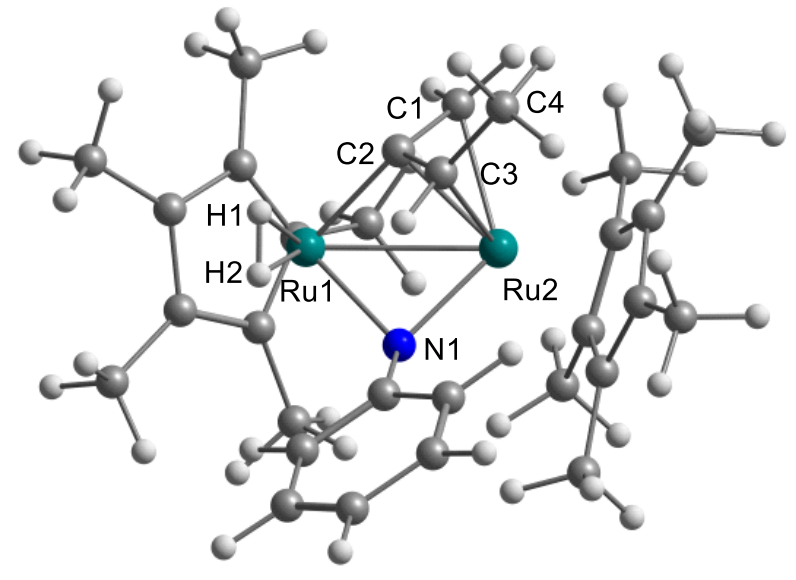

S1

$\begin{array}{lrrr}44 & -1.192401000 & -0.457255000 & -0.213603000 \\ 44 & 1.526537000 & 0.008761000 & -0.452520000 \\ 6 & 0.104556000 & -0.604812000 & -1.812171000 \\ 6 & -0.834984000 & 0.377528000 & -2.257466000 \\ 6 & -0.437642000 & -1.914064000 & -1.628101000 \\ 6 & -2.074238000 & -1.159921000 & 1.818703000 \\ 6 & -2.636199000 & 0.116553000 & 1.497319000 \\ 6 & -3.348022000 & 0.007863000 & 0.259613000 \\ 6 & -3.203871000 & -1.347044000 & -0.204938000 \\ 6 & -2.411674000 & -2.067330000 & 0.766005000 \\ 6 & -1.425739000 & -1.483147000 & 3.127177000 \\ 6 & -2.531113000 & 1.311366000 & 2.389108000 \\ 6 & -4.280598000 & 1.017260000 & -0.336944000 \\ 6 & -3.973833000 & -1.959077000 & -1.333535000 \\ 6 & -2.186605000 & -3.547991000 & 0.767642000 \\ 6 & 2.636066000 & -0.499190000 & 1.499850000\end{array}$




\begin{tabular}{|c|c|c|c|}
\hline 6 & 2.275881000 & -1.731368000 & 0.838760000 \\
\hline 6 & 2.948626000 & -1.765699000 & -0.432022000 \\
\hline 6 & 3.673266000 & -0.544745000 & -0.573924000 \\
\hline 6 & 3.499642000 & 0.233426000 & 0.638518000 \\
\hline 6 & 2.192277000 & -0.069502000 & 2.866060000 \\
\hline 6 & 1.609459000 & -2.906598000 & 1.481115000 \\
\hline 6 & 3.027247000 & -2.935017000 & -1.365808000 \\
\hline 6 & 4.614525000 & -0.207887000 & -1.692595000 \\
\hline 6 & 4.249585000 & 1.487380000 & 0.978358000 \\
\hline 7 & -0.014273000 & 1.091224000 & 0.372802000 \\
\hline 6 & -0.154174000 & 2.443996000 & 0.163764000 \\
\hline 6 & 0.894425000 & 3.331996000 & 0.528225000 \\
\hline 6 & -1.331753000 & 3.049257000 & -0.339783000 \\
\hline 6 & 0.760908000 & 4.709419000 & 0.411799000 \\
\hline 6 & -1.455583000 & 4.431790000 & -0.449511000 \\
\hline 6 & -0.416965000 & 5.283308000 & -0.074908000 \\
\hline 1 & 1.741787000 & 1.538597000 & -1.178380000 \\
\hline 1 & 1.785978000 & 0.945687000 & -1.843985000 \\
\hline 1 & 1.277698000 & 0.532603000 & 2.801937000 \\
\hline 1 & 2.961752000 & 0.534114000 & 3.358641000 \\
\hline 1 & 1.992512000 & -0.932581000 & 3.509175000 \\
\hline 1 & 3.752964000 & 2.053463000 & 1.771054000 \\
\hline 1 & 4.351459000 & 2.152596000 & 0.115353000 \\
\hline 1 & 5.263546000 & 1.246924000 & 1.328593000 \\
\hline 1 & 4.695131000 & 0.873218000 & -1.841978000 \\
\hline 1 & 4.288539000 & -0.650954000 & -2.638242000 \\
\hline 1 & 5.623602000 & -0.585725000 & -1.476455000 \\
\hline 1 & 3.932148000 & -3.526315000 & -1.165170000 \\
\hline 1 & 3.062522000 & -2.618469000 & -2.412488000 \\
\hline 1 & 2.171653000 & -3.606694000 & -1.255328000 \\
\hline 1 & 1.008826000 & -3.478073000 & 0.768247000 \\
\hline 1 & 0.955382000 & -2.600071000 & 2.298165000 \\
\hline 1 & 2.365227000 & -3.590460000 & 1.894998000 \\
\hline 1 & 0.193498000 & -2.702075000 & -1.228460000 \\
\hline 1 & -1.244876000 & -2.275975000 & -2.267862000 \\
\hline 1 & -0.520513000 & 1.416091000 & -2.178842000 \\
\hline 1 & -1.284236000 & -3.822591000 & 1.320754000 \\
\hline 1 & -2.084772000 & -3.941986000 & -0.247922000 \\
\hline 1 & -3.034610000 & -4.065491000 & 1.238502000 \\
\hline 1 & -0.607864000 & -0.794615000 & 3.357680000 \\
\hline 1 & -2.158144000 & -1.404283000 & 3.943378000 \\
\hline 1 & -1.033664000 & -2.503185000 & 3.145507000 \\
\hline 1 & -1.483181000 & 1.515047000 & 2.632318000 \\
\hline
\end{tabular}




$\begin{array}{cccc}1 & -2.935988000 & 2.211902000 & 1.923410000 \\ 1 & -3.074335000 & 1.134252000 & 3.327411000 \\ 1 & -4.148116000 & 2.006352000 & 0.107900000 \\ 1 & -5.322698000 & 0.714930000 & -0.162789000 \\ 1 & -4.144161000 & 1.115650000 & -1.418568000 \\ 1 & -4.224728000 & -1.219977000 & -2.099137000 \\ 1 & -4.917712000 & -2.385803000 & -0.964732000 \\ 1 & -3.421211000 & -2.770263000 & -1.818906000 \\ 1 & -2.136487000 & 2.399637000 & -0.662733000 \\ 1 & -2.379523000 & 4.846823000 & -0.849976000 \\ 1 & -0.517727000 & 6.361491000 & -0.163618000 \\ 1 & 1.591684000 & 5.346571000 & 0.711167000 \\ 1 & 1.810810000 & 2.904233000 & 0.923615000 \\ 6 & -1.851576000 & 0.165616000 & -3.352994000 \\ 1 & -1.416044000 & 0.431773000 & -4.328068000 \\ 1 & -2.204966000 & -0.866272000 & -3.424975000 \\ 1 & -2.724555000 & 0.814892000 & -3.213329000\end{array}$

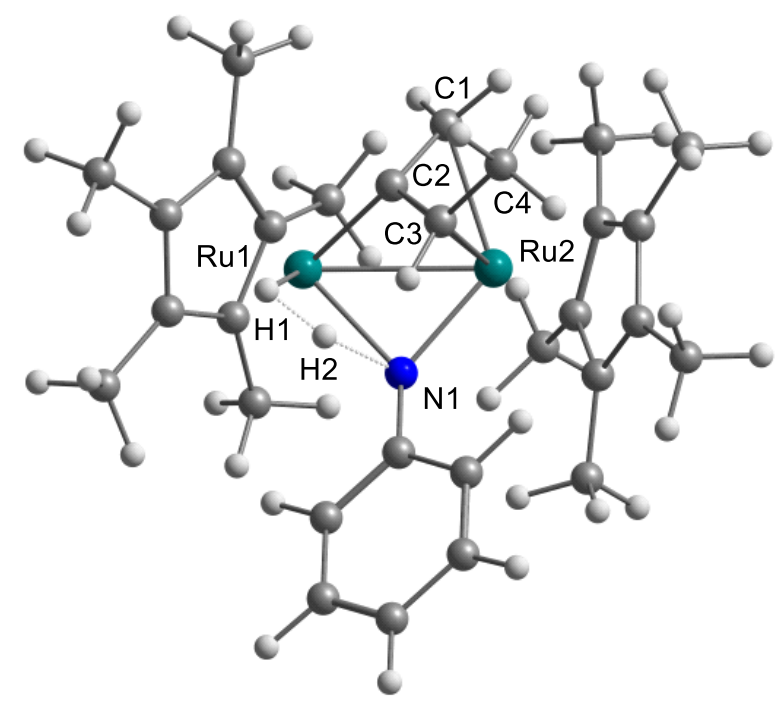

$\begin{array}{cc}\text { Selected distances }(\mathbf{A}) \\ \text { Ru1 - Ru2 } & 2.76928 \\ \text { Ru1 - C2 } & 2.06413 \\ \text { Ru1 - N1 } & 2.13063 \\ \text { Ru1 - H1 } & 1.64570 \\ \text { Ru1 - H2 } & 1.66284 \\ \text { Ru2 - C1 } & 2.17355 \\ \text { Ru2 - C2 } & 2.07495 \\ \text { Ru2 - C3 } & 2.23404 \\ \text { Ru2 - N1 } & 2.03946 \\ \text { C1 - C2 } & 1.42727 \\ \text { C2 - C3 } & 1.43719 \\ \text { C3 - C4 } & 1.51057 \\ \text { H1 - H2 } & 1.08764 \\ \text { N1 - H2 } & 1.46958\end{array}$

\section{TS2}

$\begin{array}{lrrr}44 & -1.161702000 & -0.567925000 & -0.210226000 \\ 44 & 1.529258000 & 0.051949000 & -0.418540000 \\ 6 & 0.209019000 & -0.813400000 & -1.748495000 \\ 6 & -0.831473000 & -0.027271000 & -2.352555000 \\ 6 & -0.209273000 & -2.128786000 & -1.385343000 \\ 6 & -1.926285000 & -1.164626000 & 1.888385000 \\ 6 & -2.644558000 & -0.008095000 & 1.450714000 \\ 6 & -3.350396000 & -0.327497000 & 0.242013000 \\ 6 & -3.045404000 & -1.694725000 & -0.084454000\end{array}$




$\begin{array}{cccc}6 & -2.159828000 & -2.208390000 & 0.938543000 \\ 6 & -1.210495000 & -1.274108000 & 3.196071000 \\ 6 & -2.704470000 & 1.268206000 & 2.228518000 \\ 6 & -4.400475000 & 0.499602000 & -0.434563000 \\ 6 & -3.735250000 & -2.506704000 & -1.135734000 \\ 6 & -1.747290000 & -3.640035000 & 1.088960000 \\ 6 & 2.889582000 & -0.000412000 & 1.439522000 \\ 6 & 2.633401000 & -1.364472000 & 1.066724000 \\ 6 & 3.109191000 & -1.554689000 & -0.272204000 \\ 6 & 3.659228000 & -0.312402000 & -0.730200000 \\ 6 & 3.537062000 & 0.652843000 & 0.345478000 \\ 6 & 2.611755000 & 0.594690000 & 2.785957000 \\ 6 & 2.187339000 & -2.451580000 & 1.993170000 \\ 6 & 3.198569000 & -2.855458000 & -1.010738000 \\ 6 & 4.418789000 & -0.115025000 & -2.008288000 \\ 6 & 4.140243000 & 2.025353000 & 0.348647000 \\ 1 & -0.189843000 & 1.197532000 & 0.102901000 \\ 1 & -0.523260000 & 2.534105000 & 0.013462000 \\ 6 & 0.378032000 & 3.531946000 & 0.463068000 \\ 6 & -1.752266000 & 2.980132000 & -0.528226000 \\ 6 & 0.050737000 & 4.880874000 & 0.398784000 \\ 6 & -2.071985000 & 4.333633000 & -0.572662000 \\ 6 & -1.181093000 & 5.302269000 & -0.108176000 \\ 1 & 0.751420000 & 1.398411000 & -1.007657000 \\ 1 & 1.596771000 & 1.147783000 & -1.644475000 \\ 1 & 1.508439000 & -3.223996000 & 1.477894000 \\ 1 & 3.217371000 & -2.059787000 & 2.811619000\end{array}$




$\begin{array}{lrrr}1 & 3.059905000 & -2.947169000 & 2.444248000 \\ 1 & 0.472732000 & -2.777230000 & -0.845560000 \\ 1 & -0.964117000 & -2.660076000 & -1.968600000 \\ 1 & -0.638484000 & 1.040120000 & -2.452069000 \\ 1 & -0.791863000 & -3.733765000 & 1.612880000 \\ 1 & -1.646595000 & -4.137142000 & 0.119904000 \\ 1 & -2.498363000 & -4.195123000 & 1.668573000 \\ 1 & -0.588283000 & -0.394834000 & 3.388971000 \\ 1 & -1.930359000 & -1.352420000 & 4.023918000 \\ 1 & -0.572889000 & -2.160416000 & 3.235177000 \\ 1 & -1.701770000 & 1.602371000 & 2.512484000 \\ 1 & -3.165226000 & 2.078508000 & 1.661506000 \\ 1 & -3.286749000 & 1.117476000 & 3.148116000 \\ 1 & -4.347345000 & 1.548880000 & -0.135025000 \\ 1 & -5.401899000 & 0.132666000 & -0.168790000 \\ 1 & -4.314086000 & 0.457811000 & -1.525018000 \\ 1 & -4.052751000 & -1.886455000 & -1.978150000 \\ 1 & -4.633113000 & -2.988195000 & -0.722432000 \\ 1 & -3.094048000 & -3.302725000 & -1.528158000 \\ 1 & -2.430777000 & 2.235411000 & -0.929561000 \\ 1 & -3.028436000 & 4.635713000 & -0.996792000 \\ 1 & -1.434912000 & 6.357851000 & -0.148224000 \\ 1 & 0.768182000 & 5.615517000 & 0.760458000 \\ 1 & 1.332700000 & 3.211254000 & 0.871085000 \\ 6 & -1.780431000 & -0.517749000 & -3.420600000 \\ 1 & -1.343452000 & -0.349324000 & -4.416661000 \\ 1 & -2.015532000 & -1.582864000 & -3.346174000 \\ 1 & -2.724988000 & 0.039304000 & -3.394362000\end{array}$




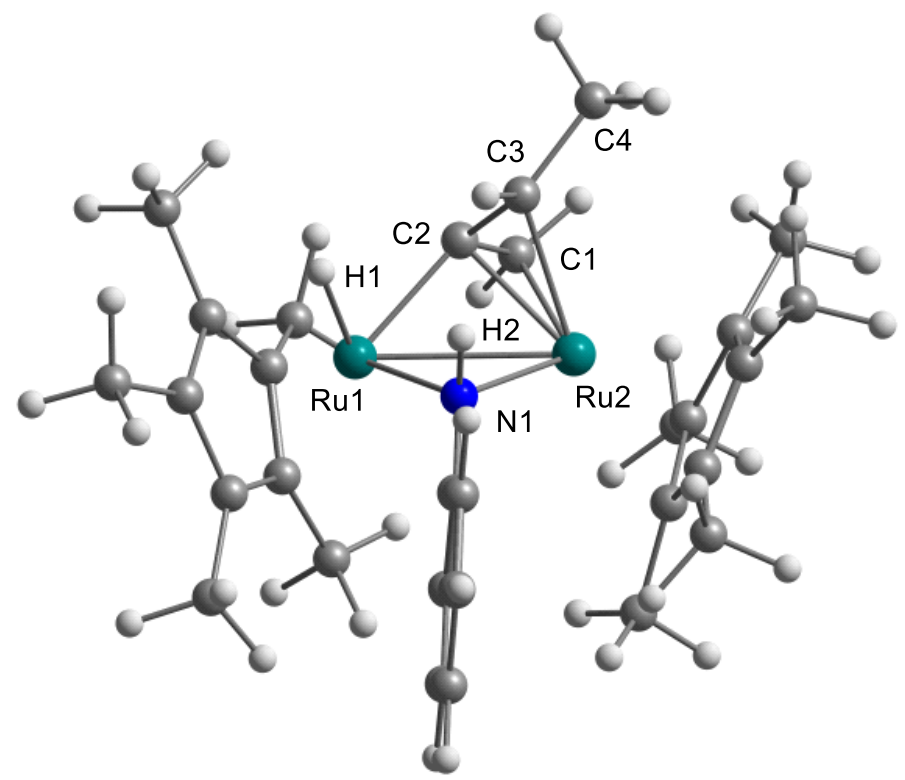

Selected distances (Â)

Ru1 - Ru2 2.78757

Ru1 - C2 2.02630

Ru1 - N1 2.07923

Ru1 - H1 1.57942

Ru2 - C1 2.17829

Ru2 - C2 2.08835

Ru2 - C3 2.22808

Ru2 - N1 2.14669

C1 - C2 1.42650

C2 - C3 1.43675

C3 - C4 1.51132

$\mathrm{N} 1-\mathrm{H} 2 \quad 1.01518$

\section{S2}

$\begin{array}{lrrr}44 & -1.330286000 & -0.470415000 & -0.182013000 \\ 44 & 1.443297000 & -0.480234000 & -0.460728000 \\ 6 & 0.023658000 & -1.796172000 & -1.059742000 \\ 6 & -0.898797000 & -1.487209000 & -2.117029000 \\ 6 & -0.572730000 & -2.502011000 & 0.027004000 \\ 6 & -2.325132000 & 0.531139000 & 1.644285000 \\ 6 & -2.898841000 & 1.102244000 & 0.453794000 \\ 6 & -3.527071000 & 0.069038000 & -0.306152000 \\ 6 & -3.336923000 & -1.166850000 & 0.400487000 \\ 6 & -2.582119000 & -0.873406000 & 1.604504000 \\ 6 & -1.790822000 & 1.281399000 & 2.825094000 \\ 6 & -3.005828000 & 2.561519000 & 0.141651000 \\ 6 & -4.371069000 & 0.271516000 & -1.526267000 \\ 6 & -4.050547000 & -2.451797000 & 0.115550000 \\ 6 & -2.321019000 & -1.831473000 & 2.725592000 \\ 6 & 3.213199000 & 0.526884000 & 0.781003000 \\ 6 & 2.635634000 & -0.481888000 & 1.606035000 \\ 6 & 2.715811000 & -1.738031000 & 0.906252000 \\ 6 & 3.347379000 & -1.501099000 & -0.361065000 \\ 6 & 3.631863000 & -0.081033000 & -0.444957000 \\ 6 & 3.498038000 & 1.945996000 & 1.164868000 \\ 6 & 2.172818000 & -0.305916000 & 3.020155000 \\ 6 & 2.457856000 & -3.090892000 & 1.497197000 \\ 6 & 3.814505000 & -2.554747000 & -1.320223000\end{array}$




\begin{tabular}{|c|c|c|c|}
\hline 6 & 4.425239000 & 0.601783000 & -1.518676000 \\
\hline 7 & 0.038393000 & 0.929485000 & -1.062511000 \\
\hline 6 & 0.124317000 & 2.300410000 & -0.736095000 \\
\hline 6 & 0.400466000 & 2.721915000 & 0.570433000 \\
\hline U & -0.053387000 & 3.277865000 & -1.727998000 \\
\hline 0 & 0.482907000 & 4.076205000 & 0.878268000 \\
\hline 6 & 0.033499000 & 4.633965000 & -1.418127000 \\
\hline 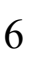 & 0.297298000 & 5.044355000 & -0.111995000 \\
\hline 1 & -0.111644000 & 0.867511000 & -2.064633000 \\
\hline 1 & 1.689508000 & -0.536221000 & -2.019835000 \\
\hline 1 & 2.945814000 & 2.248543000 & 2.058945000 \\
\hline 1 & 3.240311000 & 2.649563000 & 0.367247000 \\
\hline 1 & 4.567849000 & 2.072327000 & 1.384801000 \\
\hline 1 & 4.099305000 & 1.636847000 & -1.662320000 \\
\hline 1 & 4.322642000 & 0.088627000 & -2.479067000 \\
\hline 1 & 5.495046000 & 0.622466000 & -1.263491000 \\
\hline 1 & 3.890664000 & -2.159687000 & -2.337589000 \\
\hline 1 & 3.120458000 & -3.399925000 & -1.352422000 \\
\hline 1 & 4.804367000 & -2.939747000 & -1.034611000 \\
\hline 1 & 3.382296000 & -3.509071000 & 1.920917000 \\
\hline 1 & 2.090466000 & -3.798027000 & 0.746951000 \\
\hline 1 & 1.721901000 & -3.053001000 & 2.307118000 \\
\hline 1 & 1.378030000 & -1.012745000 & 3.276790000 \\
\hline 1 & 1.791024000 & 0.703243000 & 3.203700000 \\
\hline 1 & 2.999462000 & -0.473882000 & 3.726423000 \\
\hline 1 & 0.009648000 & -2.706589000 & 0.918054000 \\
\hline 1 & -1.396415000 & -3.200105000 & -0.137112000 \\
\hline 1 & -0.525979000 & -0.796696000 & -2.877787000 \\
\hline 1 & -1.395500000 & -1.588028000 & 3.256287000 \\
\hline 1 & -2.239219000 & -2.861951000 & 2.368415000 \\
\hline 1 & -3.141190000 & -1.799056000 & 3.457320000 \\
\hline 1 & -1.443831000 & 2.279720000 & 2.548231000 \\
\hline 1 & -2.573953000 & 1.407003000 & 3.587643000 \\
\hline 1 & -0.955691000 & 0.754980000 & 3.297631000 \\
\hline 1 & -2.219312000 & 3.148998000 & 0.618676000 \\
\hline 1 & -2.954188000 & 2.754644000 & -0.933633000 \\
\hline 1 & -3.973499000 & 2.940918000 & 0.499789000 \\
\hline 1 & -4.005920000 & 1.102858000 & -2.137011000 \\
\hline 1 & -5.411118000 & 0.497678000 & -1.249568000 \\
\hline
\end{tabular}




$\begin{array}{lrrr}1 & -4.387673000 & -0.620573000 & -2.158657000 \\ 1 & -4.299218000 & -2.553562000 & -0.944062000 \\ 1 & -4.993231000 & -2.493527000 & 0.679452000 \\ 1 & -3.463874000 & -3.328666000 & 0.408095000 \\ 1 & -0.260570000 & 2.967918000 & -2.751317000 \\ 1 & -0.107219000 & 5.371882000 & -2.204395000 \\ 1 & 0.364077000 & 6.101332000 & 0.131067000 \\ 1 & 0.700155000 & 4.380621000 & 1.899947000 \\ 1 & 0.550650000 & 1.957353000 & 1.325337000 \\ 6 & -1.891163000 & -2.458962000 & -2.712845000 \\ 1 & -1.419306000 & -3.024884000 & -3.530693000 \\ 1 & -2.267799000 & -3.189137000 & -1.992222000 \\ 1 & -2.752756000 & -1.936252000 & -3.146242000\end{array}$

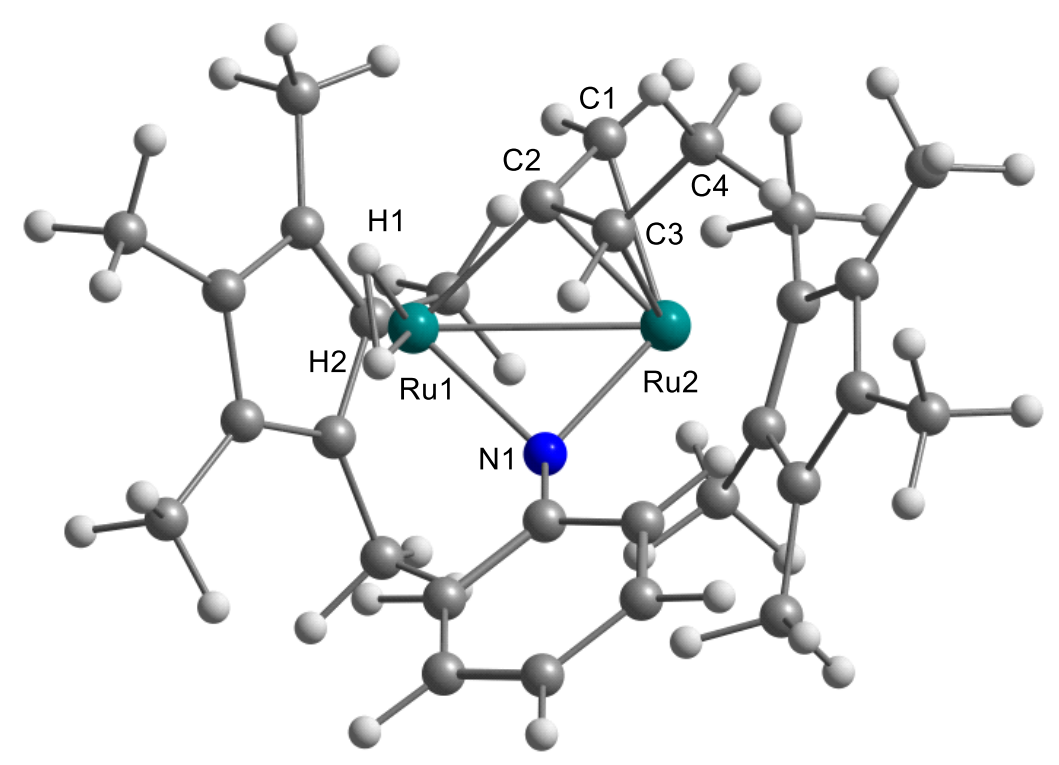

Selected distances (A)

Ru1 - Ru2 2.77121

Ru1 - C2 2.06016

Ru1 - N1 2.05245

Ru1 - H1 1.60372

Ru1 - H2 1.61381

Ru2 - C1 2.16589

Ru2 - C2 2.05670

Ru2 - C3 2.24262

Ru2 - N1 2.03405

C1 - C2 1.42820

C2 - C3 1.42592

C3 - C4 1.50893

$\mathrm{H} 1-\mathrm{H} 2 \quad 1.16494$

TS3

$\begin{array}{lrrr}44 & -1.177794000 & -0.478905000 & -0.216970000 \\ 44 & 1.529837000 & 0.035696000 & -0.506006000 \\ 6 & 0.088827000 & -0.602930000 & -1.832615000 \\ 6 & -0.862474000 & 0.364662000 & -2.270828000 \\ 6 & -0.414953000 & -1.925008000 & -1.637514000 \\ 6 & -2.030063000 & -1.205702000 & 1.823597000 \\ 6 & -2.606786000 & 0.067400000 & 1.516248000 \\ 6 & -3.332162000 & -0.041129000 & 0.286013000 \\ 6 & -3.178334000 & -1.391102000 & -0.189868000 \\ 6 & -2.367620000 & -2.108779000 & 0.767067000 \\ 6 & -1.378992000 & -1.538598000 & 3.128049000\end{array}$




\begin{tabular}{|c|c|c|c|}
\hline 6 & -2.506734000 & 1.258617000 & 2.413652000 \\
\hline 6 & -4.286835000 & 0.959198000 & -0.290399000 \\
\hline 6 & -3.954476000 & -2.002926000 & -1.314382000 \\
\hline 6 & -2.121036000 & -3.586122000 & 0.754744000 \\
\hline 6 & 2.624881000 & -0.460139000 & 1.512088000 \\
\hline 6 & 2.331520000 & -1.707416000 & 0.855147000 \\
\hline 6 & 3.002835000 & -1.707947000 & -0.411870000 \\
\hline 6 & 3.697253000 & -0.459473000 & -0.536249000 \\
\hline 6 & 3.477228000 & 0.306859000 & 0.667088000 \\
\hline 6 & 2.133911000 & -0.033610000 & 2.861564000 \\
\hline 6 & 1.687265000 & -2.904609000 & 1.479405000 \\
\hline 6 & 3.140113000 & -2.873045000 & -1.344522000 \\
\hline 6 & 4.662767000 & -0.099945000 & -1.627395000 \\
\hline 6 & 4.174231000 & 1.585615000 & 1.024476000 \\
\hline 7 & -0.012479000 & 1.091946000 & 0.341429000 \\
\hline 6 & -0.201868000 & 2.444284000 & 0.146098000 \\
\hline 6 & 0.812439000 & 3.363099000 & 0.524543000 \\
\hline 6 & -1.400062000 & 3.010961000 & -0.347999000 \\
\hline 6 & 0.628765000 & 4.735617000 & 0.428127000 \\
\hline 6 & -1.576415000 & 4.390020000 & -0.437961000 \\
\hline 6 & -0.570299000 & 5.272648000 & -0.050120000 \\
\hline 1 & 1.665360000 & 1.480733000 & -1.211624000 \\
\hline 1 & 1.890471000 & 0.614626000 & -1.957452000 \\
\hline 1 & 1.219284000 & 0.565319000 & 2.761310000 \\
\hline 1 & 2.882295000 & 0.574161000 & 3.380974000 \\
\hline 1 & 1.913952000 & -0.896566000 & 3.497607000 \\
\hline 1 & 3.631037000 & 2.141374000 & 1.793700000 \\
\hline 1 & 4.284353000 & 2.246026000 & 0.159224000 \\
\hline 1 & 5.181643000 & 1.380386000 & 1.414010000 \\
\hline 1 & 4.722672000 & 0.982815000 & -1.772556000 \\
\hline 1 & 4.375800000 & -0.547731000 & -2.583288000 \\
\hline 1 & 5.672104000 & -0.457356000 & -1.380576000 \\
\hline 1 & 4.046541000 & -3.450840000 & -1.113111000 \\
\hline 1 & 3.209993000 & -2.550775000 & -2.387577000 \\
\hline 1 & 2.291685000 & -3.559312000 & -1.270570000 \\
\hline 1 & 1.102587000 & -3.478939000 & 0.755153000 \\
\hline 1 & 1.021769000 & -2.622277000 & 2.296110000 \\
\hline 1 & 2.453262000 & -3.579409000 & 1.889066000 \\
\hline 1 & 0.244579000 & -2.693460000 & -1.244741000 \\
\hline 1 & -1.221528000 & -2.309603000 & -2.264750000 \\
\hline 1 & -0.552455000 & 1.404225000 & -2.194903000 \\
\hline 1 & -1.192075000 & -3.848413000 & 1.268450000 \\
\hline 1 & -2.055255000 & -3.974985000 & -0.265684000 \\
\hline
\end{tabular}




$\begin{array}{lrrr}1 & -2.941033000 & -4.117787000 & 1.258187000 \\ 1 & -0.583628000 & -0.832241000 & 3.380703000 \\ 1 & -2.119325000 & -1.499561000 & 3.940132000 \\ 1 & -0.958050000 & -2.547127000 & 3.126423000 \\ 1 & -1.460189000 & 1.466321000 & 2.658966000 \\ 1 & -2.913915000 & 2.159541000 & 1.950751000 \\ 1 & -3.050102000 & 1.075672000 & 3.350751000 \\ 1 & -4.163720000 & 1.946473000 & 0.160785000 \\ 1 & -5.321545000 & 0.638618000 & -0.105320000 \\ 1 & -4.166132000 & 1.068119000 & -1.372873000 \\ 1 & -4.229456000 & -1.259060000 & -2.066886000 \\ 1 & -4.885129000 & -2.449902000 & -0.936275000 \\ 1 & -3.396127000 & -2.798809000 & -1.818163000 \\ 1 & -2.179957000 & 2.336921000 & -0.680485000 \\ 1 & -2.515298000 & 4.776147000 & -0.832413000 \\ 1 & -0.710736000 & 6.347678000 & -0.122400000 \\ 1 & 1.435876000 & 5.398624000 & 0.735657000 \\ 1 & 1.746492000 & 2.964146000 & 0.906411000 \\ 6 & -1.890743000 & 0.136671000 & -3.351365000 \\ 1 & -1.470510000 & 0.406098000 & -4.332119000 \\ 1 & -2.230892000 & -0.900193000 & -3.415832000 \\ 1 & -2.770341000 & 0.774864000 & -3.202758000\end{array}$

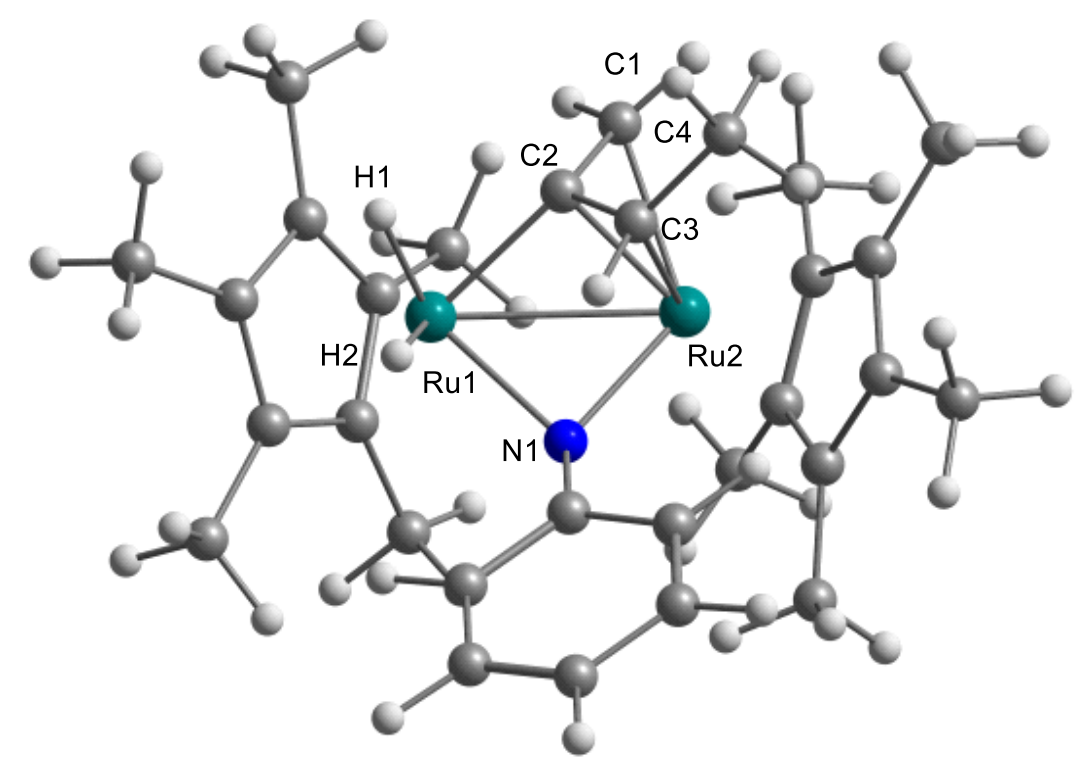

Selected distances (Å)

Ru1-Ru2 2.77893

Ru1-C2 2.07443

Ru1 - N1 2.05787

Ru1 - H1 1.57467

Ru1 - H2 1.57593

Ru2 - C1 2.17073

Ru2 - C2 2.04805

Ru2 - C3 2.25843

Ru2 - N1 2.04084

C1 - C2 1.42738

C2 - C3 1.42110

C3 - C4 1.50789

\section{S3}

$\begin{array}{lrrr}44 & -1.178722000 & -0.465317000 & -0.220504000 \\ 44 & 1.531616000 & 0.059493000 & -0.538432000 \\ 6 & 0.043226000 & -0.517399000 & -1.863260000 \\ 6 & -0.917135000 & 0.448184000 & -2.269307000\end{array}$




\begin{tabular}{|c|c|c|c|}
\hline 6 & -0.420009000 & -1.857948000 & -1.702733000 \\
\hline 6 & -1.986428000 & -1.314267000 & 1.793593000 \\
\hline 6 & -2.605867000 & -0.046144000 & 1.558204000 \\
\hline 6 & -3.342930000 & -0.114376000 & 0.330189000 \\
\hline 6 & -3.156981000 & -1.433730000 & -0.214188000 \\
\hline 6 & -2.313666000 & -2.173825000 & 0.695186000 \\
\hline 6 & -1.341414000 & -1.718321000 & 3.079295000 \\
\hline 6 & -2.578015000 & 1.093511000 & 2.525517000 \\
\hline 6 & -4.341728000 & 0.878264000 & -0.180320000 \\
\hline 6 & -3.934130000 & -2.010487000 & -1.355335000 \\
\hline 6 & -2.039142000 & -3.643320000 & 0.620830000 \\
\hline 6 & 2.593448000 & -0.613254000 & 1.526574000 \\
\hline 6 & 2.438033000 & -1.797149000 & 0.730599000 \\
\hline 6 & 3.113073000 & -1.582403000 & -0.509528000 \\
\hline 6 & 3.716519000 & -0.267649000 & -0.461586000 \\
\hline 6 & 3.396759000 & 0.322544000 & 0.808024000 \\
\hline 6 & 2.113357000 & -0.406734000 & 2.927681000 \\
\hline 6 & 1.866375000 & -3.103917000 & 1.179100000 \\
\hline 6 & 3.347026000 & -2.610715000 & -1.575192000 \\
\hline 6 & 4.703923000 & 0.279856000 & -1.448339000 \\
\hline 6 & 3.974909000 & 1.585470000 & 1.368274000 \\
\hline 7 & -0.017760000 & 1.135505000 & 0.284050000 \\
\hline 6 & -0.225028000 & 2.481241000 & 0.149899000 \\
\hline 6 & 0.821128000 & 3.414430000 & 0.406986000 \\
\hline 6 & -1.483836000 & 3.048925000 & -0.180865000 \\
\hline 6 & 0.608651000 & 4.786690000 & 0.363345000 \\
\hline 6 & -1.685341000 & 4.426471000 & -0.222375000 \\
\hline 6 & -0.647928000 & 5.319561000 & 0.052854000 \\
\hline 1 & 1.675136000 & 1.486144000 & -1.192363000 \\
\hline 1 & 1.952744000 & 0.149201000 & -2.053085000 \\
\hline 1 & 1.444668000 & 0.459279000 & 2.998425000 \\
\hline 1 & 2.960740000 & -0.222040000 & 3.601264000 \\
\hline 1 & 1.575565000 & -1.280571000 & 3.302189000 \\
\hline 1 & 3.311299000 & 2.040898000 & 2.109620000 \\
\hline 1 & 4.172247000 & 2.327791000 & 0.588813000 \\
\hline 1 & 4.931611000 & 1.378623000 & 1.870660000 \\
\hline 1 & 4.669807000 & 1.372826000 & -1.490307000 \\
\hline 1 & 4.519984000 & -0.098386000 & -2.458403000 \\
\hline 1 & 5.725886000 & -0.010338000 & -1.166053000 \\
\hline 1 & 4.232559000 & -3.219642000 & -1.341669000 \\
\hline 1 & 3.514178000 & -2.148560000 & -2.553151000 \\
\hline 1 & 2.498431000 & -3.295095000 & -1.674059000 \\
\hline 1 & 1.420105000 & -3.661620000 & 0.350414000 \\
\hline
\end{tabular}




$\begin{array}{lrrr}1 & 1.103316000 & -2.971961000 & 1.948155000 \\ 1 & 2.656989000 & -3.739924000 & 1.604509000 \\ 1 & 0.269239000 & -2.618823000 & -1.346193000 \\ 1 & -1.233961000 & -2.245902000 & -2.317969000 \\ 1 & -0.618527000 & 1.488586000 & -2.166306000 \\ 1 & -1.086832000 & -3.905490000 & 1.090050000 \\ 1 & -2.017118000 & -4.001526000 & -0.412623000 \\ 1 & -2.829199000 & -4.201417000 & 1.143986000 \\ 1 & -0.776945000 & -0.897938000 & 3.529914000 \\ 1 & -2.115604000 & -2.015650000 & 3.802617000 \\ 1 & -0.671999000 & -2.573417000 & 2.956652000 \\ 1 & -1.576259000 & 1.241685000 & 2.940146000 \\ 1 & -2.890482000 & 2.033032000 & 2.064496000 \\ 1 & -3.255729000 & 0.888354000 & 3.366288000 \\ 1 & -4.258574000 & 1.843207000 & 0.326250000 \\ 1 & -5.359188000 & 0.503039000 & -0.000109000 \\ 1 & -4.246266000 & 1.048873000 & -1.257319000 \\ 1 & -4.261728000 & -1.236487000 & -2.054758000 \\ 1 & -4.835896000 & -2.513708000 & -0.977211000 \\ 1 & -3.361945000 & -2.756421000 & -1.916397000 \\ 1 & -2.295600000 & 2.372989000 & -0.420624000 \\ 1 & -2.671969000 & 4.804761000 & -0.488128000 \\ 1 & -0.808415000 & 6.394148000 & 0.019828000 \\ 1 & 1.443315000 & 5.453718000 & 0.575990000 \\ 1 & 1.804611000 & 3.028194000 & 0.654599000 \\ 6 & -1.956397000 & 0.231358000 & -3.340122000 \\ 1 & -1.553203000 & 0.538794000 & -4.317713000 \\ 1 & -2.277534000 & -0.809657000 & -3.431141000 \\ 1 & -2.845181000 & 0.848953000 & -3.162449000\end{array}$




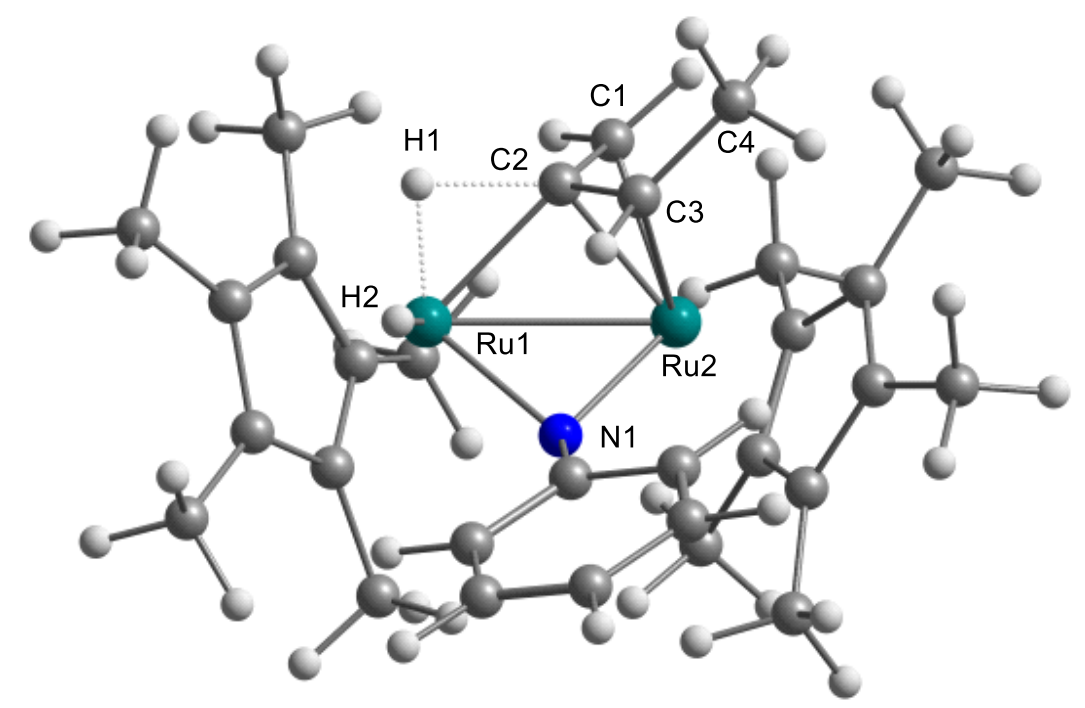

Selected distances (A)

Ru1-Ru2 2.73714

Ru1 - C2 2.10795

Ru1 - N1 2.03955

Ru1 - H1 1.60616

Ru1 - H2 1.57321

Ru2 - C1 2.17345

Ru2 - C2 2.04512

Ru2 - C3 2.24152

Ru2 - N1 2.03619

C1 - C2 1.42613

C2 - C3 1.42110

C3 - C4 1.50776

C2 - $\mathrm{H} 1 \quad 1.58541$

TS4

$\begin{array}{lrrr}44 & -1.166140000 & -0.498969000 & -0.233732000 \\ 44 & 1.502153000 & 0.046323000 & -0.507208000 \\ 6 & 0.021503000 & -0.515101000 & -1.898593000 \\ 6 & -0.952282000 & 0.458791000 & -2.249014000 \\ 6 & -0.409969000 & -1.865701000 & -1.745067000 \\ 6 & -1.898870000 & -1.315383000 & 1.801824000 \\ 6 & -2.556931000 & -0.066748000 & 1.560712000 \\ 6 & -3.336177000 & -0.181105000 & 0.365017000 \\ 6 & -3.134553000 & -1.504441000 & -0.159394000 \\ 6 & -2.244031000 & -2.206278000 & 0.736654000 \\ 6 & -1.176008000 & -1.652050000 & 3.065101000 \\ 6 & -2.480671000 & 1.103231000 & 2.488583000 \\ 6 & -4.366055000 & 0.785279000 & -0.133647000 \\ 6 & -3.915648000 & -2.118220000 & -1.279531000 \\ 6 & -1.929639000 & -3.669064000 & 0.676081000 \\ 6 & 2.669749000 & -0.408913000 & 1.499298000 \\ 6 & 2.504158000 & -1.678860000 & 0.853990000 \\ 6 & 3.101418000 & -1.592702000 & -0.439342000 \\ 6 & 3.677345000 & -0.277861000 & -0.581913000 \\ 6 & 3.418586000 & 0.449422000 & 0.632218000 \\ 6 & 2.194334000 & -0.024534000 & 2.866192000 \\ 6 & 1.982917000 & -2.944888000 & 1.458851000 \\ 6 & 3.290832000 & -2.733865000 & -1.393234000 \\ 6 & 4.584596000 & 0.169690000 & -1.689630000 \\ 6 & 4.023477000 & 1.768611000 & 1.005210000 \\ 7 & -0.032478000 & 1.094787000 & 0.332682000 \\ 6 & -0.284631000 & 2.440830000 & 0.159745000 \\ 6 & 0.716155000 & 3.396422000 & 0.473998000 \\ 6 & -1.536203000 & 2.964427000 & -0.240317000\end{array}$




\begin{tabular}{|c|c|c|c|}
\hline 6 & 0.470337000 & 4.760974000 & 0.412178000 \\
\hline 6 & -1.775704000 & 4.335628000 & -0.297059000 \\
\hline 6 & -0.781335000 & 5.254429000 & 0.031873000 \\
\hline 1 & 1.639721000 & 1.439453000 & -1.225029000 \\
\hline 1 & 1.535616000 & -0.093669000 & -2.106910000 \\
\hline 1 & 1.321333000 & 0.637227000 & 2.793578000 \\
\hline 1 & 2.976213000 & 0.503823000 & 3.423807000 \\
\hline 1 & 1.909466000 & -0.902112000 & 3.453034000 \\
\hline 1 & 3.459175000 & 2.262007000 & 1.801216000 \\
\hline 1 & 4.065320000 & 2.453642000 & 0.153588000 \\
\hline 1 & 5.051397000 & 1.627032000 & 1.369093000 \\
\hline 1 & 4.535078000 & 1.252765000 & -1.833503000 \\
\hline 1 & 4.320640000 & -0.299428000 & -2.642182000 \\
\hline 1 & 5.628605000 & -0.092573000 & -1.467033000 \\
\hline 1 & 4.228478000 & -3.267068000 & -1.180311000 \\
\hline 1 & 3.336972000 & -2.391390000 & -2.431464000 \\
\hline 1 & 2.479087000 & -3.464676000 & -1.322601000 \\
\hline 1 & 1.285858000 & -3.461625000 & 0.791505000 \\
\hline 1 & 1.469408000 & -2.763221000 & 2.404897000 \\
\hline 1 & 2.810636000 & -3.638953000 & 1.664393000 \\
\hline 1 & 0.310469000 & -2.611037000 & -1.420679000 \\
\hline 1 & -1.223868000 & -2.257845000 & -2.357184000 \\
\hline 1 & -0.636804000 & 1.492976000 & -2.142595000 \\
\hline 1 & -0.971639000 & -3.896888000 & 1.151160000 \\
\hline 1 & -1.885270000 & -4.032391000 & -0.354780000 \\
\hline 1 & -2.703752000 & -4.249785000 & 1.197655000 \\
\hline 1 & -0.492683000 & -0.853142000 & 3.362949000 \\
\hline 1 & -1.894122000 & -1.792702000 & 3.886328000 \\
\hline 1 & -0.605097000 & -2.578658000 & 2.973041000 \\
\hline 1 & -1.436944000 & 1.355474000 & 2.701596000 \\
\hline 1 & -2.947863000 & 1.995376000 & 2.067326000 \\
\hline 1 & -2.979509000 & 0.867777000 & 3.438590000 \\
\hline 1 & -4.245055000 & 1.777015000 & 0.308097000 \\
\hline 1 & -5.370801000 & 0.427519000 & 0.131447000 \\
\hline 1 & -4.336441000 & 0.896235000 & -1.221848000 \\
\hline 1 & -4.245705000 & -1.365232000 & -2.000504000 \\
\hline 1 & -4.813609000 & -2.619867000 & -0.891508000 \\
\hline 1 & -3.335935000 & -2.871186000 & -1.823791000 \\
\hline 1 & -2.308806000 & 2.262698000 & -0.529865000 \\
\hline 1 & -2.755390000 & 4.686723000 & -0.618398000 \\
\hline 1 & -0.969860000 & 6.323582000 & -0.013629000 \\
\hline 1 & 1.271733000 & 5.452767000 & 0.666780000 \\
\hline 1 & 1.693173000 & 3.033475000 & 0.771588000 \\
\hline
\end{tabular}




$\begin{array}{llcc}6 & -2.017201000 & 0.258040000 & -3.297343000 \\ 1 & -1.639259000 & 0.568782000 & -4.282959000 \\ 1 & -2.348703000 & -0.780163000 & -3.384528000 \\ 1 & -2.895475000 & 0.879823000 & -3.088447000\end{array}$

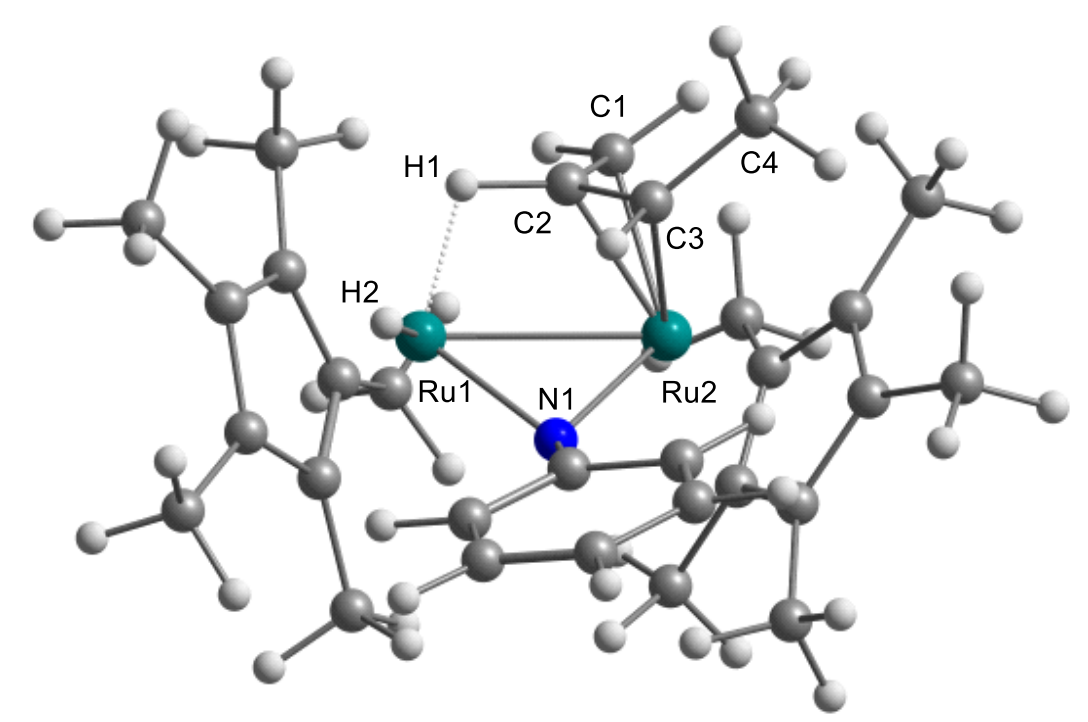

$\begin{array}{cc}\text { Selected distances (A) } \\ \text { Ru1 - Ru2 } & 2.71259 \\ \text { Ru1 - C2 } & 2.32384 \\ \text { Ru1 - N1 } & 2.04101 \\ \text { Ru1 - H1 } & 1.78204 \\ \text { Ru1 - H2 } & 1.57898 \\ \text { Ru2 - C1 } & 2.16983 \\ \text { Ru2 - C2 } & 2.06527 \\ \text { Ru2 - C3 } & 2.21943 \\ \text { Ru2 - N1 } & 2.02802 \\ \text { C1 - C2 } & 1.42637 \\ \text { C2 - C3 } & 1.42642 \\ \text { C3 - C4 } & 1.50600 \\ \text { C2 - H1 } & 1.17998\end{array}$

\section{S4}

$\begin{array}{lrrr}44 & -1.135378000 & -0.513252000 & -0.250578000 \\ 44 & 1.505009000 & 0.085134000 & -0.419197000 \\ 6 & -0.088506000 & -0.433734000 & -2.029084000 \\ 6 & -1.124899000 & 0.529555000 & -2.209742000 \\ 6 & -0.435969000 & -1.805159000 & -1.847435000 \\ 6 & -1.776918000 & -1.310754000 & 1.801475000 \\ 6 & -2.575134000 & -0.149598000 & 1.536452000 \\ 6 & -3.364524000 & -0.396630000 & 0.372479000 \\ 6 & -3.035424000 & -1.706916000 & -0.108787000 \\ 6 & -2.049761000 & -2.276520000 & 0.781292000 \\ 6 & -1.000461000 & -1.506129000 & 3.061553000 \\ 6 & -2.613850000 & 1.042365000 & 2.437887000 \\ 6 & -4.488782000 & 0.447986000 & -0.140753000 \\ 6 & -3.773088000 & -2.451433000 & -1.178153000 \\ 6 & -1.599255000 & -3.704447000 & 0.772982000 \\ 6 & 2.713830000 & -0.374055000 & 1.436661000 \\ 6 & 2.623508000 & -1.647658000 & 0.772320000 \\ 6 & 3.176228000 & -1.498306000 & -0.531596000 \\ 6 & 3.663460000 & -0.150008000 & -0.673844000 \\ 6 & 3.398648000 & 0.541687000 & 0.565708000 \\ 6 & 2.352474000 & -0.066753000 & 2.857236000 \\ 6 & 2.211257000 & -2.951247000 & 1.379163000 \\ 6 & 3.359903000 & -2.591198000 & -1.541229000\end{array}$




\begin{tabular}{|c|c|c|c|}
\hline 6 & 4.497147000 & 0.366527000 & -1.808727000 \\
\hline 6 & 3.953658000 & 1.872755000 & 0.970090000 \\
\hline 7 & -0.080423000 & 1.107800000 & 0.359443000 \\
\hline 6 & -0.376492000 & 2.438860000 & 0.176924000 \\
\hline 6 & 0.612911000 & 3.434822000 & 0.395775000 \\
\hline 6 & -1.673498000 & 2.922407000 & -0.132249000 \\
\hline 6 & 0.316074000 & 4.789796000 & 0.342337000 \\
\hline 6 & -1.960383000 & 4.283289000 & -0.186970000 \\
\hline 6 & -0.975821000 & 5.239981000 & 0.055750000 \\
\hline 1 & 1.709171000 & 1.490101000 & -1.110246000 \\
\hline 1 & 1.030857000 & -0.074180000 & -2.129595000 \\
\hline 1 & 1.650596000 & 0.772288000 & 2.911073000 \\
\hline 1 & 3.245981000 & 0.199952000 & 3.437036000 \\
\hline 1 & 1.887149000 & -0.924525000 & 3.347816000 \\
\hline 1 & 3.354563000 & 2.334723000 & 1.759503000 \\
\hline 1 & 3.995054000 & 2.571304000 & 0.129534000 \\
\hline 1 & 4.976018000 & 1.754615000 & 1.357638000 \\
\hline 1 & 4.409505000 & 1.452535000 & -1.903502000 \\
\hline 1 & 4.193986000 & -0.070254000 & -2.765444000 \\
\hline 1 & 5.559183000 & 0.126561000 & -1.656331000 \\
\hline 1 & 4.348566000 & -3.059287000 & -1.432252000 \\
\hline 1 & 3.290809000 & -2.211077000 & -2.565341000 \\
\hline 1 & 2.612259000 & -3.382414000 & -1.428372000 \\
\hline 1 & 1.674352000 & -3.585332000 & 0.667254000 \\
\hline 1 & 1.574586000 & -2.813308000 & 2.255491000 \\
\hline 1 & 3.098244000 & -3.512805000 & 1.707714000 \\
\hline 1 & 0.357936000 & -2.517096000 & -1.641017000 \\
\hline 1 & -1.288556000 & -2.214922000 & -2.387834000 \\
\hline 1 & -0.805283000 & 1.564321000 & -2.112260000 \\
\hline 1 & -0.638031000 & -3.827185000 & 1.278031000 \\
\hline 1 & -1.492979000 & -4.092601000 & -0.244363000 \\
\hline 1 & -2.329920000 & -4.340172000 & 1.293452000 \\
\hline 1 & -0.425492000 & -0.612758000 & 3.316672000 \\
\hline 1 & -1.683861000 & -1.708908000 & 3.899425000 \\
\hline 1 & -0.313144000 & -2.352156000 & 2.993132000 \\
\hline 1 & -1.608361000 & 1.457882000 & 2.563079000 \\
\hline 1 & -3.251298000 & 1.837639000 & 2.047320000 \\
\hline 1 & -2.993889000 & 0.754363000 & 3.427604000 \\
\hline 1 & -4.388071000 & 1.494919000 & 0.155482000 \\
\hline 1 & -5.443244000 & 0.083726000 & 0.264715000 \\
\hline 1 & -4.565761000 & 0.412227000 & -1.231344000 \\
\hline 1 & -4.170376000 & -1.779942000 & -1.944908000 \\
\hline 1 & -4.625625000 & -2.996171000 & -0.748094000 \\
\hline
\end{tabular}




$\begin{array}{lrrr}1 & -3.138597000 & -3.192068000 & -1.675915000 \\ 1 & -2.446982000 & 2.195398000 & -0.351524000 \\ 1 & -2.972976000 & 4.597608000 & -0.437354000 \\ 1 & -1.202410000 & 6.301744000 & 0.011954000 \\ 1 & 1.113066000 & 5.509500000 & 0.523957000 \\ 1 & 1.622921000 & 3.109129000 & 0.615752000 \\ 6 & -2.279792000 & 0.342682000 & -3.158083000 \\ 1 & -2.002046000 & 0.704068000 & -4.159760000 \\ 1 & -2.591638000 & -0.700314000 & -3.260126000 \\ 1 & -3.146313000 & 0.932439000 & -2.840651000\end{array}$

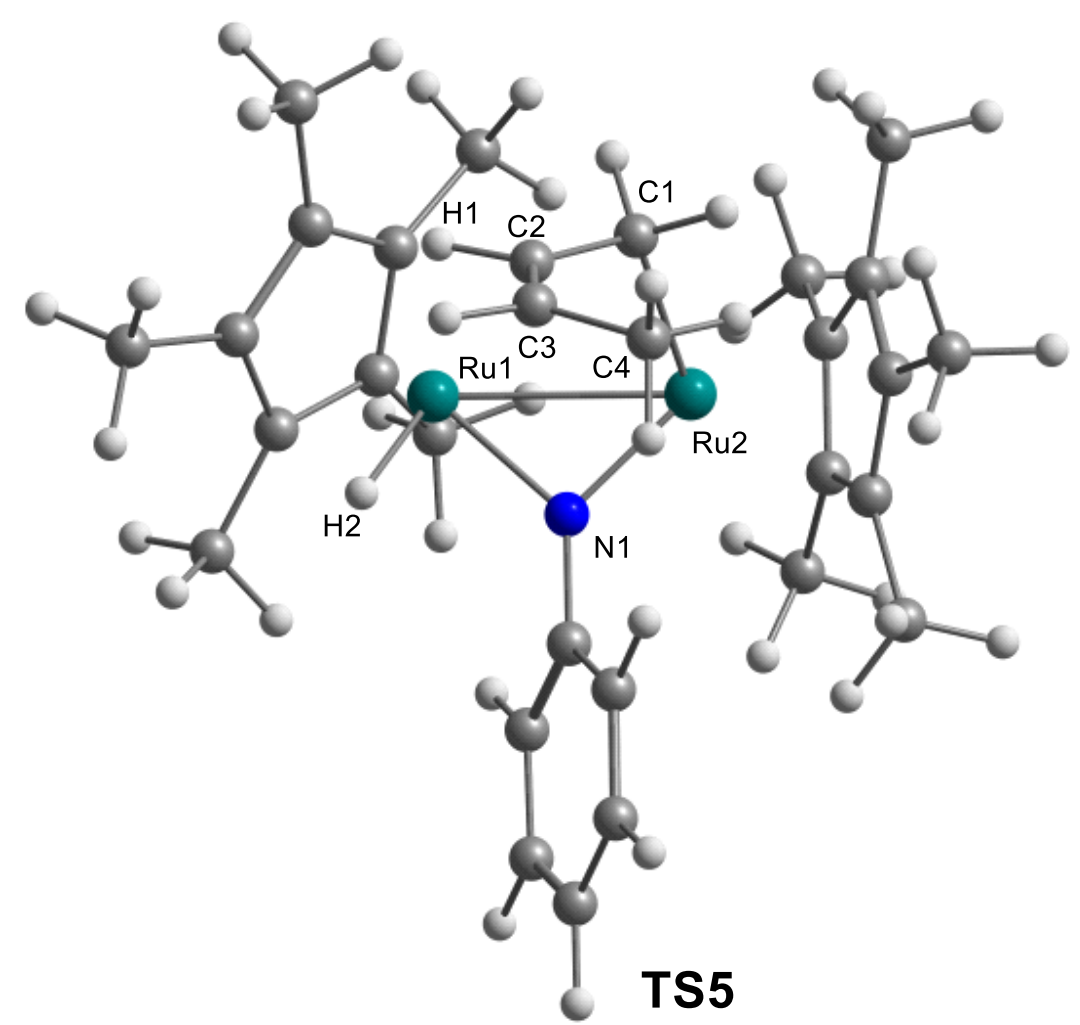

Selected distances (A)

Ru1-Ru2 2.75289

Ru1 - C2 2.89128

Ru1 - C3 3.84022

Ru1 - N1 1.94248

Ru1 - H1 2.47807

Ru1 - H2 1.59990

Ru2 - C1 2.17258

Ru2 - C2 3.09960

Ru2 - C3 3.94852

Ru2 - N1 1.86272

C1 - C2 1.48302

C2 - C3 1.34914

C3 - C4 1.49601

$\begin{array}{lrrr}44 & 1.111000000 & -0.522731000 & -0.023362000 \\ 44 & -1.543068000 & 0.158629000 & 0.241313000 \\ 6 & -0.432821000 & -1.080588000 & 2.605880000 \\ 6 & -0.079502000 & -0.441935000 & 3.740545000 \\ 6 & 0.410165000 & -1.778540000 & 1.605091000 \\ 6 & 2.453019000 & -0.325769000 & -1.787202000 \\ 6 & 3.166140000 & 0.016667000 & -0.594338000 \\ 6 & 3.202674000 & -1.164815000 & 0.240770000 \\ 6 & 2.570643000 & -2.241915000 & -0.482825000 \\ 6 & 2.081022000 & -1.722485000 & -1.708629000 \\ 6 & 2.234700000 & 0.573035000 & -2.964815000 \\ 6 & 3.906527000 & 1.292282000 & -0.339012000\end{array}$




\begin{tabular}{|c|c|c|c|}
\hline 6 & 3.991488000 & -1.307448000 & 1.503958000 \\
\hline 6 & 2.506263000 & -3.673036000 & -0.049153000 \\
\hline 6 & 1.472183000 & -2.517771000 & -2.819611000 \\
\hline 6 & -2.536160000 & -0.254558000 & -1.618209000 \\
\hline 6 & -2.553231000 & -1.522100000 & -0.930979000 \\
\hline 6 & -3.286007000 & -1.348956000 & 0.285637000 \\
\hline 6 & -3.755020000 & -0.001048000 & 0.357445000 \\
\hline 6 & -3.300378000 & 0.693124000 & -0.831466000 \\
\hline 6 & -2.018932000 & -0.007764000 & -3.000406000 \\
\hline 6 & -2.039115000 & -2.829695000 & -1.445270000 \\
\hline 6 & -3.587461000 & -2.436388000 & 1.269708000 \\
\hline 6 & -4.674057000 & 0.553308000 & 1.403370000 \\
\hline 6 & -3.733053000 & 2.055085000 & -1.278220000 \\
\hline 7 & 0.169961000 & 1.072232000 & 0.177271000 \\
\hline 6 & 0.532972000 & 2.418973000 & 0.132065000 \\
\hline 6 & 0.129293000 & 3.245324000 & -0.929700000 \\
\hline 6 & 1.312477000 & 2.971190000 & 1.161455000 \\
\hline 6 & 0.514351000 & 4.582296000 & -0.968951000 \\
\hline 6 & 1.673001000 & 4.315671000 & 1.128633000 \\
\hline 6 & 1.283600000 & 5.126826000 & 0.061668000 \\
\hline 1 & -1.881677000 & 1.487623000 & 1.065205000 \\
\hline 1 & -1.504210000 & -1.085266000 & 2.384218000 \\
\hline 1 & -1.704536000 & 1.031479000 & -3.130253000 \\
\hline 1 & -2.797568000 & -0.217256000 & -3.748099000 \\
\hline 1 & -1.159033000 & -0.644410000 & -3.222581000 \\
\hline 1 & -2.990414000 & 2.516819000 & -1.934674000 \\
\hline 1 & -3.880279000 & 2.727913000 & -0.428809000 \\
\hline 1 & -4.680002000 & 1.998377000 & -1.834732000 \\
\hline 1 & -4.578742000 & 1.639753000 & 1.480835000 \\
\hline 1 & -4.460082000 & 0.136108000 & 2.392092000 \\
\hline 1 & -5.721869000 & 0.323444000 & 1.163199000 \\
\hline 1 & -4.462774000 & -3.014610000 & 0.941785000 \\
\hline 1 & -3.813116000 & -2.036709000 & 2.262551000 \\
\hline 1 & -2.751579000 & -3.135217000 & 1.371317000 \\
\hline 1 & -1.543093000 & -3.410843000 & -0.661007000 \\
\hline 1 & -1.320607000 & -2.685294000 & -2.254278000 \\
\hline 1 & -2.864748000 & -3.441921000 & -1.838214000 \\
\hline 1 & -0.133886000 & -2.625802000 & 1.172259000 \\
\hline 1 & 1.331447000 & -2.152002000 & 2.062530000 \\
\hline 1 & -0.877338000 & 0.016071000 & 4.326081000 \\
\hline 1 & 0.775535000 & -1.922272000 & -3.417283000 \\
\hline 1 & 0.933575000 & -3.393067000 & -2.446559000 \\
\hline 1 & 2.255118000 & -2.878956000 & -3.502469000 \\
\hline
\end{tabular}




$\begin{array}{rrrr}1 & 2.104831000 & 1.614443000 & -2.654178000 \\ 1 & 3.092378000 & 0.534271000 & -3.651984000 \\ 1 & 1.345574000 & 0.284784000 & -3.533708000 \\ 1 & 3.423626000 & 2.146751000 & -0.820546000 \\ 1 & 3.969497000 & 1.516675000 & 0.729765000 \\ 1 & 4.933744000 & 1.224298000 & -0.725588000 \\ 1 & 4.038393000 & -0.364055000 & 2.056032000 \\ 1 & 5.023745000 & -1.617629000 & 1.285947000 \\ 1 & 3.562443000 & -2.062771000 & 2.170035000 \\ 1 & 1.656434000 & -4.194485000 & -0.500766000 \\ 1 & 2.409240000 & -3.770849000 & 1.036476000 \\ 1 & 3.418660000 & -4.209334000 & -0.345003000 \\ 1 & 1.605498000 & 2.326602000 & 1.985185000 \\ 1 & 2.264673000 & 4.732325000 & 1.940617000 \\ 1 & 1.571707000 & 6.174493000 & 0.035451000 \\ 1 & 0.204235000 & 5.206436000 & -1.804125000 \\ 1 & -0.484323000 & 2.815205000 & -1.715694000 \\ 6 & 1.304001000 & -0.265049000 & 4.281548000 \\ 1 & 1.383661000 & -0.639516000 & 5.312067000 \\ 1 & 2.053640000 & -0.779716000 & 3.674974000 \\ 1 & 1.580744000 & 0.799427000 & 4.317273000\end{array}$

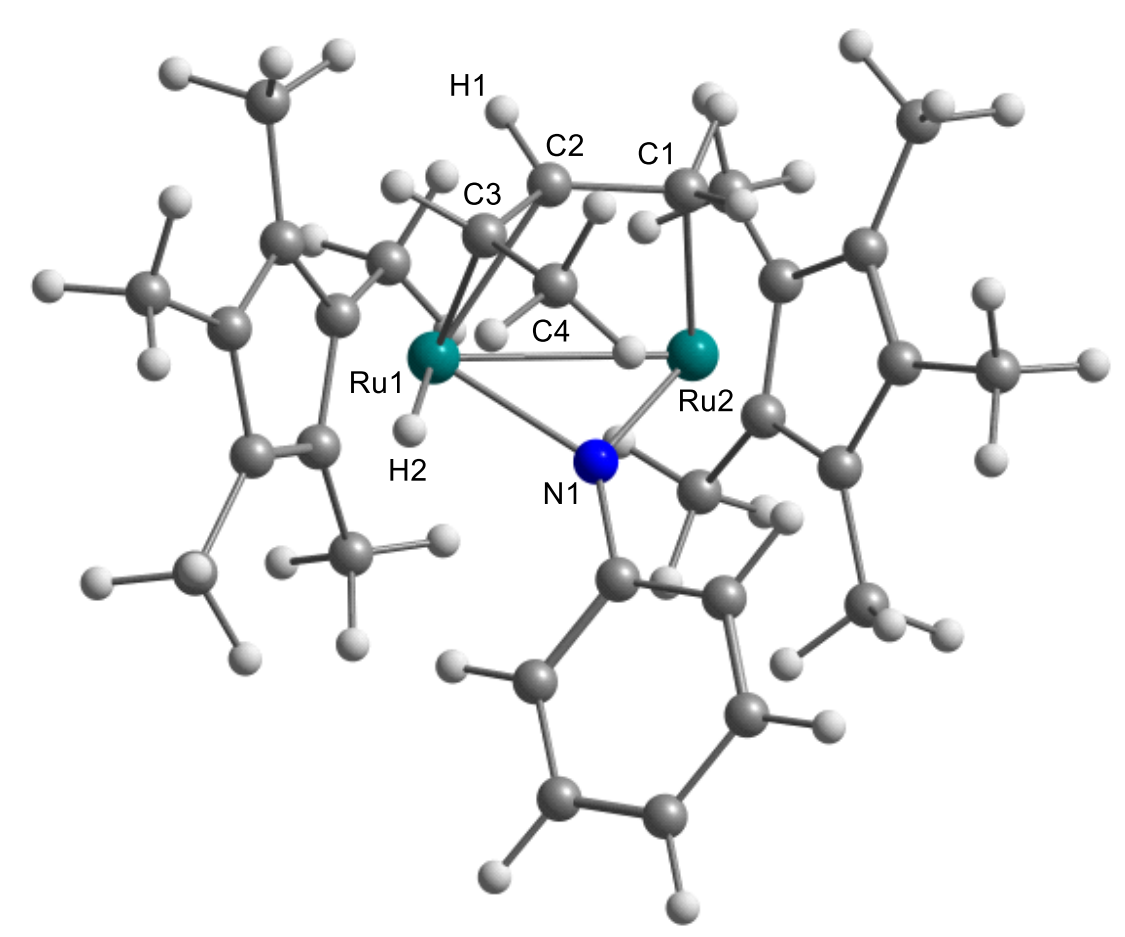

Selected distances (Â)

Ru1 - Ru2 2.88470

Ru1 - C2 2.26180

Ru1 - C3 2.15530

Ru1 - N1 2.04987

Ru1 - H2 1.58297

Ru2 - C1 2.10386

Ru2 - C2 2.72561

Ru2 - C3 3.56859

Ru2 - N1 1.82397

C1 - C2 1.46359

C2 - C3 1.42763

C3 - C4 1.51219

\section{S5}




\begin{tabular}{|c|c|c|c|}
\hline 44 & 1.558411000 & -0.082505000 & -0.391480000 \\
\hline 6 & 0.523021000 & -1.254558000 & -2.025496000 \\
\hline 6 & 1.387743000 & -0.238928000 & -2.534306000 \\
\hline 6 & -0.937927000 & -1.207412000 & -2.099755000 \\
\hline 6 & -2.445384000 & -0.869200000 & 1.649603000 \\
\hline 6 & -3.068705000 & 0.217157000 & 0.926450000 \\
\hline 6 & -3.524284000 & -0.307595000 & -0.333303000 \\
\hline 6 & -3.243467000 & -1.721510000 & -0.339193000 \\
\hline 6 & -2.573071000 & -2.068466000 & 0.857268000 \\
\hline 6 & -2.010124000 & -0.817902000 & 3.082032000 \\
\hline 6 & -3.368851000 & 1.576163000 & 1.479036000 \\
\hline 6 & -4.345550000 & 0.413916000 & -1.356384000 \\
\hline 6 & -3.692663000 & -2.675809000 & -1.400095000 \\
\hline 6 & -2.198348000 & -3.455233000 & 1.280602000 \\
\hline 6 & 2.400728000 & -0.314525000 & 1.768850000 \\
\hline 6 & 2.202380000 & -1.619800000 & 1.214543000 \\
\hline 6 & 3.012759000 & -1.732781000 & 0.030310000 \\
\hline 6 & 3.699888000 & -0.491292000 & -0.160321000 \\
\hline 6 & 3.315339000 & 0.390624000 & 0.925325000 \\
\hline 6 & 1.842617000 & 0.166699000 & 3.072596000 \\
\hline 6 & 1.460451000 & -2.745984000 & 1.862708000 \\
\hline 6 & 3.228744000 & -2.981387000 & -0.770216000 \\
\hline 6 & 4.780129000 & -0.225963000 & -1.164684000 \\
\hline 6 & 3.968237000 & 1.707238000 & 1.222244000 \\
\hline 7 & -0.156361000 & 1.026728000 & -0.215097000 \\
\hline 6 & -0.330476000 & 2.400437000 & -0.059803000 \\
\hline 6 & 0.452009000 & 3.145827000 & 0.838826000 \\
\hline 6 & -1.294157000 & 3.081226000 & -0.826503000 \\
\hline 6 & 0.257447000 & 4.514643000 & 0.986252000 \\
\hline 6 & -1.469223000 & 4.456339000 & -0.692452000 \\
\hline 6 & -0.701080000 & 5.181154000 & 0.219001000 \\
\hline 1 & 2.027223000 & 1.280973000 & -1.044887000 \\
\hline 1 & 0.943311000 & -2.246246000 & -1.875166000 \\
\hline 1 & 1.881035000 & 1.256580000 & 3.154050000 \\
\hline 1 & 2.412117000 & -0.243744000 & 3.918685000 \\
\hline 1 & 0.799256000 & -0.134900000 & 3.197164000 \\
\hline 1 & 3.351961000 & 2.339185000 & 1.867318000 \\
\hline 1 & 4.174493000 & 2.272625000 & 0.309190000 \\
\hline 1 & 4.924268000 & 1.547820000 & 1.741056000 \\
\hline 1 & 4.832324000 & 0.835297000 & -1.426082000 \\
\hline 1 & 4.614628000 & -0.783799000 & -2.091776000 \\
\hline 1 & 5.763510000 & -0.523874000 & -0.773976000 \\
\hline 1 & 4.136046000 & -3.505244000 & -0.438870000 \\
\hline
\end{tabular}




$\begin{array}{lrrr}1 & 3.348001000 & -2.768367000 & -1.838390000 \\ 1 & 2.393259000 & -3.680528000 & -0.663097000 \\ 1 & 0.965878000 & -3.385149000 & 1.126226000 \\ 1 & 0.693787000 & -2.374370000 & 2.546270000 \\ 1 & 2.147219000 & -3.377270000 & 2.446365000 \\ 1 & -1.371990000 & -2.203075000 & -2.181019000 \\ 1 & -1.353096000 & -0.543186000 & -2.865846000 \\ 1 & 2.365296000 & -0.584423000 & -2.876676000 \\ 1 & -1.399504000 & -3.448747000 & 2.026244000 \\ 1 & -1.851588000 & -4.058365000 & 0.434693000 \\ 1 & -3.057235000 & -3.978325000 & 1.725862000 \\ 1 & -1.631885000 & 0.170993000 & 3.356834000 \\ 1 & -2.855357000 & -1.042249000 & 3.749589000 \\ 1 & -1.226145000 & -1.549831000 & 3.296687000 \\ 1 & -2.605211000 & 1.902542000 & 2.191358000 \\ 1 & -3.415284000 & 2.334508000 & 0.693296000 \\ 1 & -4.335255000 & 1.573027000 & 2.003212000 \\ 1 & -4.213277000 & 1.496954000 & -1.281188000 \\ 1 & -5.416841000 & 0.202097000 & -1.226034000 \\ 1 & -4.074026000 & 0.116408000 & -2.374919000 \\ 1 & -3.691488000 & -2.218590000 & -2.394634000 \\ 1 & -4.720500000 & -3.006361000 & -1.195339000 \\ 1 & -3.066515000 & -3.573001000 & -1.440752000 \\ 1 & -1.880842000 & 2.507696000 & -1.539044000 \\ 1 & -2.208886000 & 4.964853000 & -1.307021000 \\ 1 & -0.839878000 & 6.253927000 & 0.324394000 \\ 1 & 0.865041000 & 5.069517000 & 1.697835000 \\ 1 & 1.207633000 & 2.621484000 & 1.412352000 \\ 6 & 0.850986000 & 0.902487000 & -3.368444000 \\ 1 & 0.528801000 & 0.546965000 & -4.359945000 \\ 1 & -0.002401000 & 1.392255000 & -2.891962000 \\ 1 & 1.621350000 & 1.666267000 & -3.522828000\end{array}$




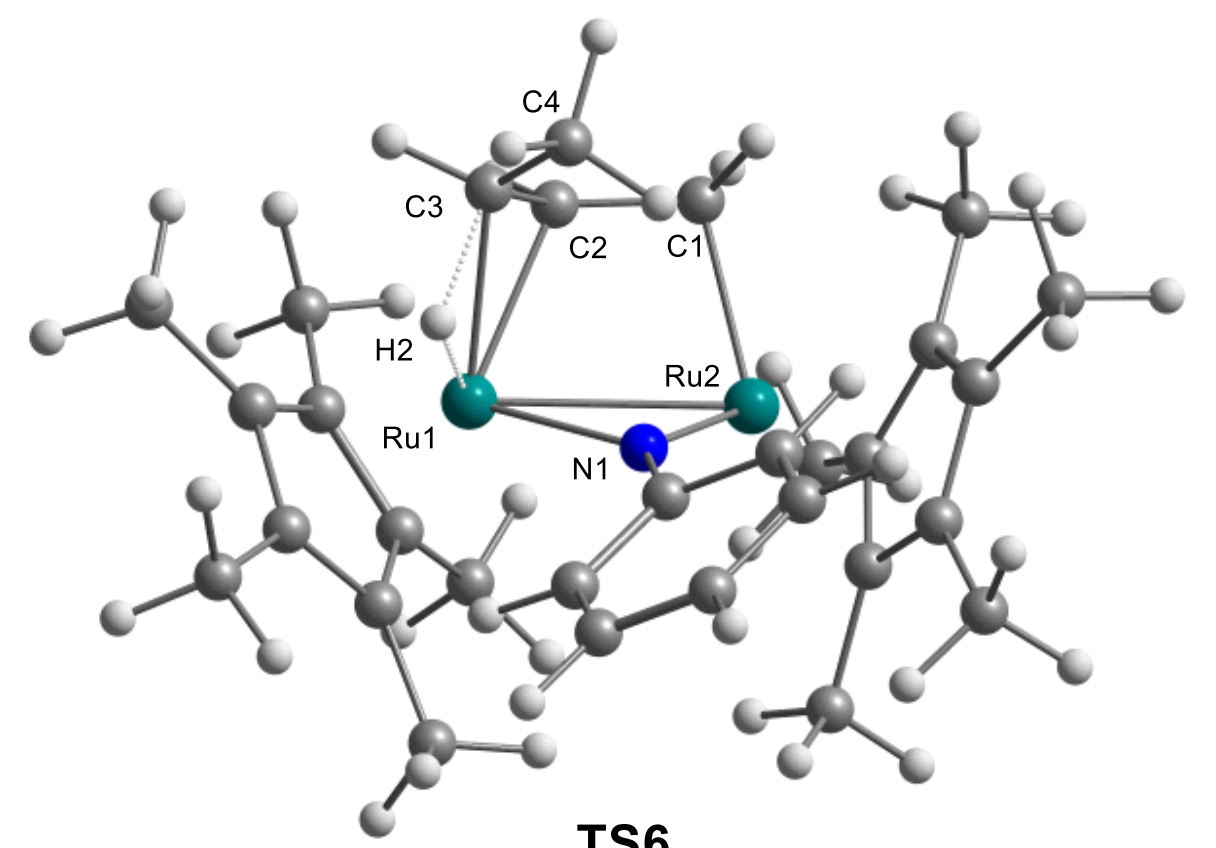

Selected distances $(\hat{A})$

Ru1 - Ru2 2.83783

Ru1 - C2 2.19619

Ru1 - C3 2.23500

Ru1 - N1 2.05462

Ru1 - H2 1.62810

Ru2 - C1 2.11927

Ru2 - C2 2.79949

Ru2 - C3 3.57528

Ru2 - N1 1.83001

C1 - C2 1.46521

C2 - C3 1.44422

C3 - C4 1.51811

C3 - H2 1.56111

TS6

$\begin{array}{lrcc}44 & -1.299925000 & -0.354278000 & -0.174021000 \\ 44 & 1.525190000 & -0.163522000 & -0.362719000 \\ 6 & 0.578993000 & -1.091559000 & -2.113924000 \\ 6 & 1.315071000 & 0.061739000 & -2.576384000 \\ 6 & -0.884346000 & -1.161274000 & -2.089055000 \\ 6 & -2.481133000 & -0.872069000 & 1.621690000 \\ 6 & -3.110030000 & 0.220914000 & 0.913480000 \\ 6 & -3.532832000 & -0.279983000 & -0.364605000 \\ 6 & -3.223114000 & -1.687057000 & -0.401778000 \\ 6 & -2.578460000 & -2.056741000 & 0.802877000 \\ 6 & -2.075776000 & -0.833325000 & 3.063536000 \\ 6 & -3.449841000 & 1.550875000 & 1.513520000 \\ 6 & -4.343682000 & 0.447620000 & -1.391699000 \\ 6 & -3.633868000 & -2.619463000 & -1.497172000 \\ 6 & -2.206877000 & -3.449932000 & 1.206927000 \\ 6 & 2.453578000 & -0.258347000 & 1.703775000 \\ 6 & 2.134478000 & -1.597901000 & 1.290459000 \\ 6 & 2.878841000 & -1.886737000 & 0.097143000 \\ 6 & 3.645820000 & -0.725641000 & -0.237426000 \\ 6 & 3.394772000 & 0.285925000 & 0.771138000 \\ 6 & 1.982164000 & 0.371251000 & 2.978822000 \\ 6 & 1.366716000 & -2.600974000 & 2.090080000 \\ 6 & 2.931318000 & -3.213994000 & -0.595064000 \\ 6 & 4.668701000 & -0.624716000 & -1.328596000 \\ 6 & 4.174235000 & 1.558991000 & 0.913136000 \\ 7 & -0.120684000 & 1.044486000 & -0.131875000\end{array}$




\begin{tabular}{|c|c|c|c|}
\hline 6 & -0.233103000 & 2.421136000 & 0.029167000 \\
\hline 6 & 0.738358000 & 3.170900000 & 0.717185000 \\
\hline 6 & -1.316414000 & 3.116431000 & -0.544951000 \\
\hline 6 & 0.608794000 & 4.547889000 & 0.862203000 \\
\hline 6 & -1.434501000 & 4.495877000 & -0.410676000 \\
\hline 6 & -0.477804000 & 5.221863000 & 0.300568000 \\
\hline 1 & 1.904273000 & 0.978954000 & -1.458961000 \\
\hline 1 & 1.093059000 & -2.049423000 & -2.174173000 \\
\hline 1 & 2.153662000 & 1.450811000 & 2.989982000 \\
\hline 1 & 2.509585000 & -0.054862000 & 3.843959000 \\
\hline 1 & 0.910744000 & 0.208209000 & 3.128237000 \\
\hline 1 & 3.672412000 & 2.279275000 & 1.565035000 \\
\hline 1 & 4.335497000 & 2.048374000 & -0.052233000 \\
\hline 1 & 5.161601000 & 1.358387000 & 1.353663000 \\
\hline 1 & 4.749880000 & 0.398014000 & -1.711200000 \\
\hline 1 & 4.425867000 & -1.276232000 & -2.174424000 \\
\hline 1 & 5.662604000 & -0.920275000 & -0.964607000 \\
\hline 1 & 3.699470000 & -3.860285000 & -0.147787000 \\
\hline 1 & 3.174272000 & -3.110536000 & -1.658039000 \\
\hline 1 & 1.974858000 & -3.742150000 & -0.523826000 \\
\hline 1 & 0.815054000 & -3.293194000 & 1.449484000 \\
\hline 1 & 0.650289000 & -2.114643000 & 2.755079000 \\
\hline 1 & 2.049548000 & -3.195248000 & 2.716176000 \\
\hline 1 & -1.231067000 & -2.192257000 & -2.154288000 \\
\hline 1 & -1.404991000 & -0.536985000 & -2.826101000 \\
\hline 1 & 2.278268000 & -0.174438000 & -3.032643000 \\
\hline 1 & -1.456154000 & -3.452533000 & 2.001136000 \\
\hline 1 & -1.799131000 & -4.023353000 & 0.367484000 \\
\hline 1 & -3.082450000 & -3.998762000 & 1.583802000 \\
\hline 1 & -1.648281000 & 0.135129000 & 3.340331000 \\
\hline 1 & -2.948180000 & -1.003180000 & 3.712083000 \\
\hline 1 & -1.341278000 & -1.606822000 & 3.302182000 \\
\hline 1 & -2.642758000 & 1.931640000 & 2.146969000 \\
\hline 1 & -3.642361000 & 2.308908000 & 0.750594000 \\
\hline 1 & -4.352457000 & 1.468775000 & 2.136270000 \\
\hline 1 & -4.247084000 & 1.532225000 & -1.286023000 \\
\hline 1 & -5.411992000 & 0.202481000 & -1.300917000 \\
\hline 1 & -4.034103000 & 0.185717000 & -2.409292000 \\
\hline 1 & -3.575739000 & -2.149438000 & -2.484243000 \\
\hline 1 & -4.675419000 & -2.936785000 & -1.348575000 \\
\hline 1 & -3.019439000 & -3.525135000 & -1.518678000 \\
\hline 1 & -2.043569000 & 2.542504000 & -1.112826000 \\
\hline 1 & -2.274674000 & 5.009938000 & -0.872852000 \\
\hline
\end{tabular}




$\begin{array}{lrrr}1 & -0.569071000 & 6.300064000 & 0.402934000 \\ 1 & 1.368351000 & 5.103126000 & 1.408510000 \\ 1 & 1.592880000 & 2.643375000 & 1.123066000 \\ 6 & 0.595888000 & 1.186665000 & -3.298868000 \\ 1 & 0.250832000 & 0.832224000 & -4.279952000 \\ 1 & -0.272946000 & 1.535298000 & -2.736667000 \\ 1 & 1.257555000 & 2.044744000 & -3.462052000\end{array}$

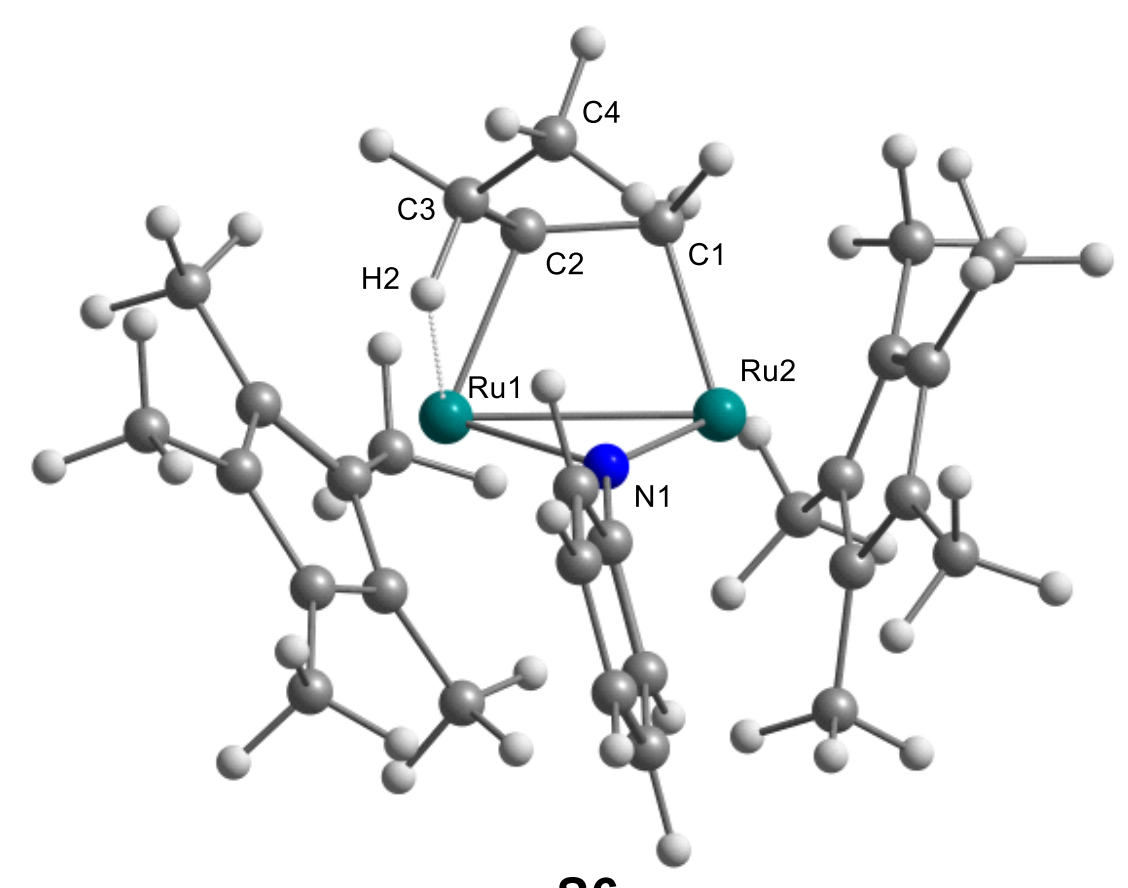

Selected distances (A)

Ru1 - Ru2 2.85458

Ru1 - C2 2.16539

Ru1 - C3 2.37932

Ru1 - N1 2.03140

Ru1 - H2 1.84106

Ru2 - C1 2.13781

Ru2 - C2 2.80549

Ru2 - C3 3.59137

Ru2 - N1 1.84358

C1 - C2 1.45454

C2 - C3 1.49541

C3 - C4 1.52630

$\mathrm{C} 3-\mathrm{H} 2 \quad 1.18802$

\section{S6}

$\begin{array}{lrrr}44 & 1.389190000 & -0.265260000 & 0.195650000 \\ 44 & -1.457519000 & -0.465969000 & 0.263281000 \\ 6 & -0.459133000 & -1.781501000 & 1.663818000 \\ 6 & -1.212557000 & -0.883906000 & 2.592760000 \\ 6 & 0.995183000 & -1.791262000 & 1.640056000 \\ 6 & 2.749346000 & 0.134901000 & -1.487145000 \\ 6 & 3.204899000 & 0.820547000 & -0.303705000 \\ 6 & 3.553529000 & -0.190991000 & 0.666973000 \\ 6 & 3.386960000 & -1.476602000 & 0.043168000 \\ 6 & 2.850187000 & -1.289301000 & -1.255461000 \\ 6 & 2.491984000 & 0.755174000 & -2.826941000 \\ 6 & 3.475629000 & 2.287009000 & -0.163209000 \\ 6 & 4.174737000 & 0.052834000 & 2.007349000 \\ 6 & 3.798317000 & -2.785275000 & 0.639997000 \\ 6 & 2.591842000 & -2.355348000 & -2.274724000 \\ 6 & -2.054097000 & -0.558054000 & -1.816838000\end{array}$




\begin{tabular}{|c|c|c|c|}
\hline 6 & -2.237014000 & -1.860359000 & -1.205018000 \\
\hline 6 & -3.224876000 & -1.726558000 & -0.175709000 \\
\hline 6 & -3.642989000 & -0.342196000 & -0.149496000 \\
\hline 6 & -2.962948000 & 0.367536000 & -1.185054000 \\
\hline 6 & -1.267092000 & -0.284421000 & -3.059605000 \\
\hline 6 & -1.595481000 & -3.134578000 & -1.661302000 \\
\hline 6 & -3.809082000 & -2.833965000 & 0.648011000 \\
\hline 6 & -4.711801000 & 0.221027000 & 0.738297000 \\
\hline 6 & -3.206781000 & 1.785323000 & -1.594253000 \\
\hline 7 & 0.004832000 & 0.940311000 & 0.365794000 \\
\hline 6 & -0.172008000 & 2.318044000 & 0.263626000 \\
\hline 6 & 0.102822000 & 3.022368000 & -0.922878000 \\
\hline 6 & -0.655472000 & 3.051686000 & 1.365482000 \\
\hline 6 & -0.088585000 & 4.401028000 & -1.000702000 \\
\hline 6 & -0.837664000 & 4.428223000 & 1.284003000 \\
\hline 6 & -0.555976000 & 5.115968000 & 0.100971000 \\
\hline 1 & -1.746887000 & 0.008341000 & 2.018499000 \\
\hline 1 & -0.932485000 & -2.745036000 & 1.470290000 \\
\hline 1 & -0.854699000 & 0.728210000 & -3.061778000 \\
\hline 1 & -1.903286000 & -0.386421000 & -3.951129000 \\
\hline 1 & -0.434933000 & -0.985595000 & -3.164417000 \\
\hline 1 & -2.311122000 & 2.240076000 & -2.025465000 \\
\hline 1 & -3.501681000 & 2.406611000 & -0.743144000 \\
\hline 1 & -4.007083000 & 1.843892000 & -2.346489000 \\
\hline 1 & -4.577925000 & 1.295175000 & 0.896705000 \\
\hline 1 & -4.721807000 & -0.262380000 & 1.720534000 \\
\hline 1 & -5.704630000 & 0.071428000 & 0.291171000 \\
\hline 1 & -4.683353000 & -3.280713000 & 0.153559000 \\
\hline 1 & -4.139534000 & -2.478794000 & 1.630166000 \\
\hline 1 & -3.086556000 & -3.639518000 & 0.816333000 \\
\hline 1 & -1.555178000 & -3.875224000 & -0.856332000 \\
\hline 1 & -0.568525000 & -2.959816000 & -1.994557000 \\
\hline 1 & -2.154202000 & -3.583933000 & -2.495149000 \\
\hline 1 & 1.385190000 & -2.751746000 & 1.306498000 \\
\hline 1 & 1.503599000 & -1.459899000 & 2.553026000 \\
\hline 1 & -2.080732000 & -1.401749000 & 3.013348000 \\
\hline 1 & 1.815379000 & -2.050145000 & -2.983102000 \\
\hline 1 & 2.263889000 & -3.290271000 & -1.809387000 \\
\hline 1 & 3.497674000 & -2.577331000 & -2.858529000 \\
\hline 1 & 2.280250000 & 1.824557000 & -2.744694000 \\
\hline 1 & 3.378751000 & 0.648483000 & -3.468878000 \\
\hline 1 & 1.653095000 & 0.283832000 & -3.346664000 \\
\hline 1 & 2.768710000 & 2.891639000 & -0.737591000 \\
\hline
\end{tabular}




$\begin{array}{lrrr}1 & 3.396828000 & 2.608961000 & 0.879706000 \\ 1 & 4.489968000 & 2.530032000 & -0.511262000 \\ 1 & 3.859544000 & 1.015092000 & 2.422069000 \\ 1 & 5.272518000 & 0.061058000 & 1.943198000 \\ 1 & 3.896412000 & -0.723498000 & 2.728007000 \\ 1 & 3.658834000 & -2.810276000 & 1.725426000 \\ 1 & 4.864532000 & -2.965802000 & 0.445224000 \\ 1 & 3.243488000 & -3.625741000 & 0.210622000 \\ 1 & -0.878042000 & 2.519338000 & 2.286041000 \\ 1 & -1.202812000 & 4.970346000 & 2.153728000 \\ 1 & -0.701315000 & 6.191196000 & 0.040053000 \\ 1 & 0.128961000 & 4.918401000 & -1.932965000 \\ 1 & 0.453281000 & 2.464415000 & -1.785132000 \\ 6 & -0.420450000 & -0.157843000 & 3.676723000 \\ 1 & 0.038513000 & -0.882598000 & 4.359875000 \\ 1 & 0.374747000 & 0.452533000 & 3.238987000 \\ 1 & -1.073305000 & 0.497722000 & 4.264880000\end{array}$

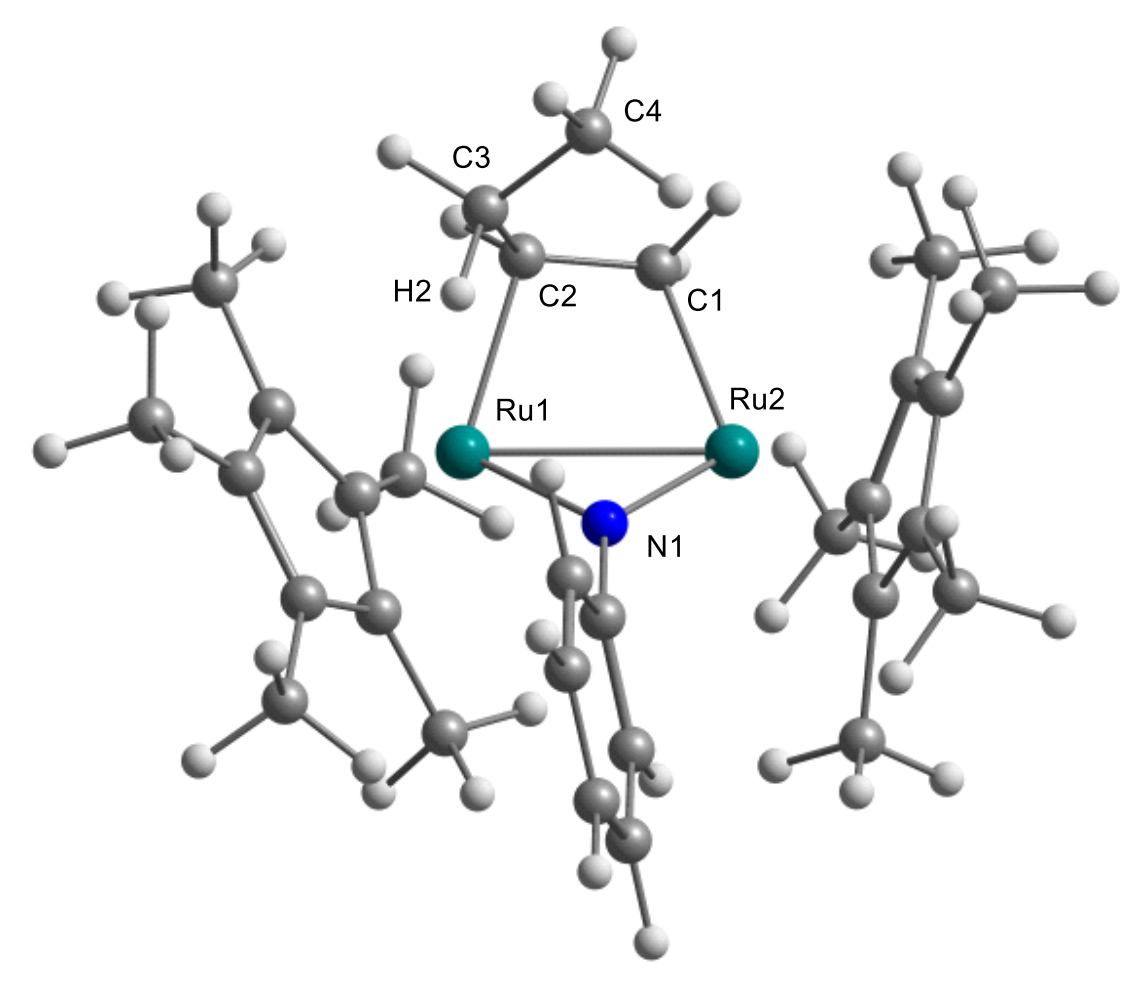

Selected distances (Â)

Ru1 - Ru2 2.76515

Ru1 - C2 2.15005

Ru1 - C3 2.66072

Ru1 - N1 1.95696

Ru1 - H2 2.24246

Ru2 - C1 2.18216

Ru2 - C2 2.96823

Ru2 - C3 3.67423

Ru2 - N1 1.88341

C1 - C2 1.45098

C2 - C3 1.52587

C3 - C4 1.52847

C3 - H2 1.12159

\section{TS7}

$\begin{array}{lrrr}44 & 1.377657000 & -0.325462000 & 0.102978000 \\ 44 & -1.385556000 & -0.419973000 & 0.144929000 \\ 6 & -0.684628000 & -2.127395000 & 1.247713000 \\ 6 & -1.090802000 & -1.479049000 & 2.567920000\end{array}$




\begin{tabular}{|c|c|c|c|}
\hline 6 & 0.721097000 & -2.244572000 & 0.907807000 \\
\hline 6 & 2.820432000 & 0.360826000 & -1.362026000 \\
\hline 6 & 3.264947000 & 0.767606000 & -0.055042000 \\
\hline 6 & 3.528786000 & -0.435790000 & 0.700978000 \\
\hline 6 & 3.315065000 & -1.559241000 & -0.160242000 \\
\hline 6 & 2.817201000 & -1.088543000 & -1.411042000 \\
\hline 6 & 2.630266000 & 1.243605000 & -2.557882000 \\
\hline 6 & 3.551116000 & 2.164569000 & 0.401856000 \\
\hline 6 & 4.089928000 & -0.492124000 & 2.087880000 \\
\hline 6 & 3.628107000 & -2.981376000 & 0.182501000 \\
\hline 6 & 2.537574000 & -1.915782000 & -2.627317000 \\
\hline 6 & -2.279125000 & -0.071981000 & -1.740863000 \\
\hline 6 & -2.423061000 & -1.484889000 & -1.429307000 \\
\hline 6 & -3.290945000 & -1.588596000 & -0.292149000 \\
\hline 6 & -3.670194000 & -0.267841000 & 0.111647000 \\
\hline 6 & -3.080580000 & 0.673528000 & -0.790326000 \\
\hline 6 & -1.626039000 & 0.476372000 & -2.970898000 \\
\hline 6 & -1.893821000 & -2.615552000 & -2.256475000 \\
\hline 6 & -3.811648000 & -2.855500000 & 0.314588000 \\
\hline 6 & -4.608061000 & 0.062381000 & 1.231273000 \\
\hline 6 & -3.345332000 & 2.146321000 & -0.812691000 \\
\hline 7 & 0.005999000 & 0.938106000 & 0.366005000 \\
\hline 6 & -0.088967000 & 2.327914000 & 0.385162000 \\
\hline 6 & 0.166054000 & 3.120713000 & -0.748611000 \\
\hline 6 & -0.452934000 & 2.982092000 & 1.578240000 \\
\hline 6 & 0.064994000 & 4.509785000 & -0.689253000 \\
\hline 6 & -0.548498000 & 4.369483000 & 1.633125000 \\
\hline 6 & -0.290866000 & 5.145006000 & 0.500623000 \\
\hline 1 & -1.425753000 & -0.424038000 & 2.387030000 \\
\hline 1 & -1.307435000 & -2.974615000 & 0.959733000 \\
\hline 1 & -1.344225000 & 1.524492000 & -2.840122000 \\
\hline 1 & -2.306502000 & 0.419704000 & -3.833026000 \\
\hline 1 & -0.720472000 & -0.085633000 & -3.217648000 \\
\hline 1 & -2.512615000 & 2.702720000 & -1.250830000 \\
\hline 1 & -3.498527000 & 2.543686000 & 0.195482000 \\
\hline 1 & -4.245964000 & 2.370982000 & -1.402250000 \\
\hline 1 & -4.387164000 & 1.041715000 & 1.666718000 \\
\hline 1 & -4.556766000 & -0.680843000 & 2.032973000 \\
\hline 1 & -5.647180000 & 0.087723000 & 0.873061000 \\
\hline 1 & -4.843583000 & -3.043716000 & -0.012144000 \\
\hline 1 & -3.818442000 & -2.818493000 & 1.409995000 \\
\hline 1 & -3.217107000 & -3.723853000 & 0.015924000 \\
\hline 1 & -1.708921000 & -3.509146000 & -1.651618000 \\
\hline
\end{tabular}




$\begin{array}{lrrc}1 & -0.946750000 & -2.343911000 & -2.731351000 \\ 1 & -2.602935000 & -2.893444000 & -3.050401000 \\ 1 & 0.915310000 & -3.033823000 & 0.180064000 \\ 1 & 1.399474000 & -2.320582000 & 1.765675000 \\ 1 & -1.997946000 & -1.972084000 & 2.938984000 \\ 1 & 1.838203000 & -1.407798000 & -3.298688000 \\ 1 & 2.095592000 & -2.882385000 & -2.365457000 \\ 1 & 3.456995000 & -2.114245000 & -3.198481000 \\ 1 & 2.520338000 & 2.292495000 & -2.271558000 \\ 1 & 3.505239000 & 1.174859000 & -3.220534000 \\ 1 & 1.751101000 & 0.959158000 & -3.145792000 \\ 1 & 2.896542000 & 2.891820000 & -0.086784000 \\ 1 & 3.396797000 & 2.268722000 & 1.480559000 \\ 1 & 4.591749000 & 2.446157000 & 0.185131000 \\ 1 & 3.756126000 & 0.361346000 & 2.685996000 \\ 1 & 5.189538000 & -0.477267000 & 2.072587000 \\ 1 & 3.782618000 & -1.404001000 & 2.610106000 \\ 1 & 3.312901000 & -3.248541000 & 1.197169000 \\ 1 & 4.711723000 & -3.150403000 & 0.123969000 \\ 1 & 3.150531000 & -3.682107000 & -0.508478000 \\ 1 & -0.646674000 & 2.375993000 & 2.459456000 \\ 1 & -0.823376000 & 4.849957000 & 2.569678000 \\ 1 & -0.365350000 & 6.228278000 & 0.545950000 \\ 1 & 0.265416000 & 5.099415000 & -1.581615000 \\ 1 & 0.436718000 & 2.624485000 & -1.674330000 \\ 6 & -0.028343000 & -1.416384000 & 3.664943000 \\ 1 & 0.336386000 & -2.418991000 & 3.919885000 \\ 1 & 0.830178000 & -0.813393000 & 3.349100000 \\ 1 & -0.440597000 & -0.961501000 & 4.573170000\end{array}$




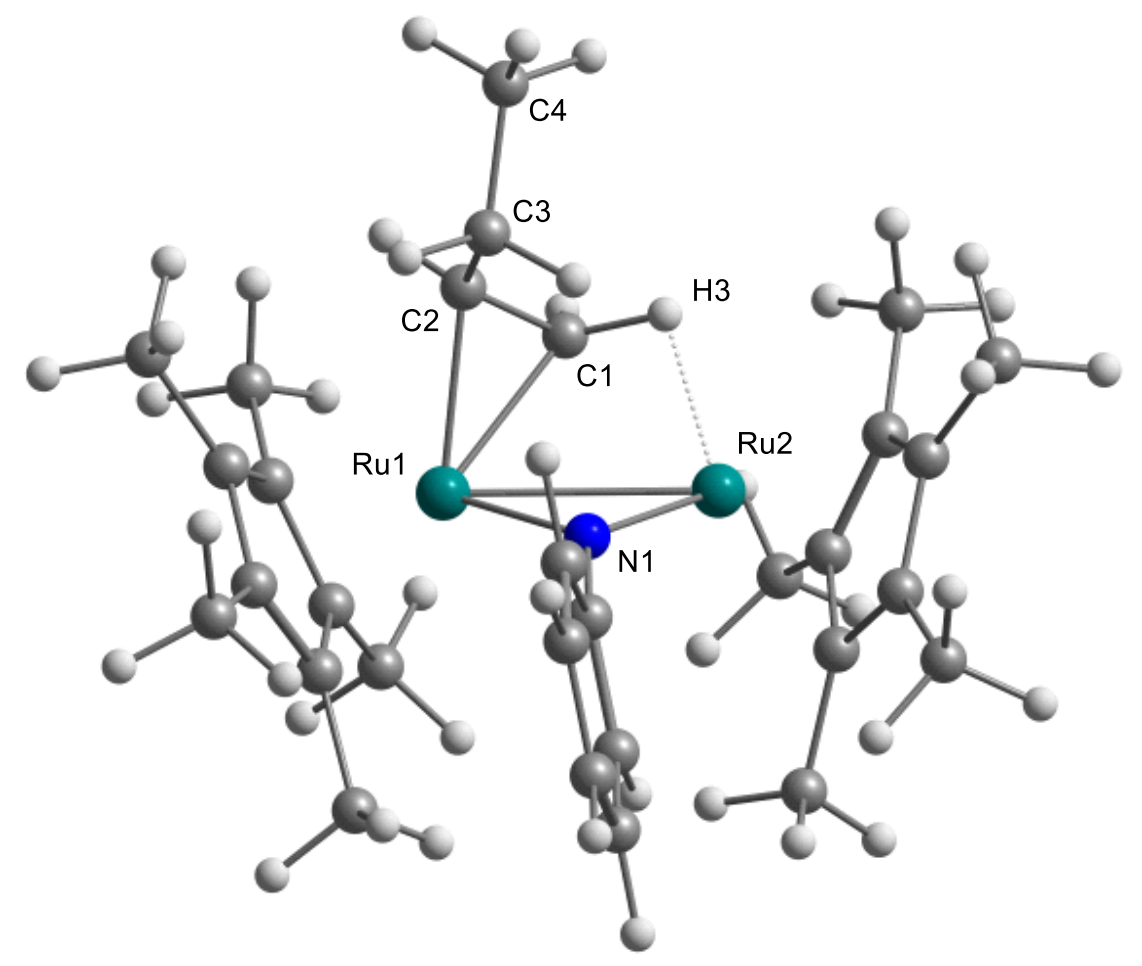

Selected distances (Â)

Ru1-Ru2 2.83883

Ru1 - C1 2.15382

Ru1 - C2 2.12439

Ru1 - N1 1.91172

Ru2 - C1 2.28512

Ru2 - H3 1.88589

Ru2 - N1 1.95003

C1 - C2 1.44095

C2 - C3 1.51366

C3 - C4 1.53352

C1 - H3 1.15257

\section{S7}

$\begin{array}{lrrr}44 & 1.516397000 & -0.374136000 & 0.170053000 \\ 44 & -1.317180000 & -0.418952000 & 0.003344000 \\ 6 & -1.194348000 & -1.466895000 & 1.847186000 \\ 6 & -1.131278000 & -0.637065000 & 3.111536000 \\ 6 & -0.037959000 & -1.797264000 & 1.053488000 \\ 6 & 2.859498000 & 0.069497000 & -1.455531000 \\ 6 & 3.356252000 & 0.701091000 & -0.262404000 \\ 6 & 3.617436000 & -0.341868000 & 0.698939000 \\ 6 & 3.359195000 & -1.615495000 & 0.063356000 \\ 6 & 2.871106000 & -1.370270000 & -1.250921000 \\ 6 & 2.591369000 & 0.733889000 & -2.770684000 \\ 6 & 3.664941000 & 2.154044000 & -0.081686000 \\ 6 & 4.220839000 & -0.145406000 & 2.056113000 \\ 6 & 3.578191000 & -2.958580000 & 0.690417000 \\ 6 & 2.552656000 & -2.398623000 & -2.291454000 \\ 6 & -2.247351000 & -1.066400000 & -1.898157000 \\ 6 & -2.920543000 & -1.764886000 & -0.848234000 \\ 6 & -3.532550000 & -0.779457000 & 0.004622000 \\ 6 & -3.297871000 & 0.525603000 & -0.551849000 \\ 6 & -2.499079000 & 0.353032000 & -1.722676000 \\ 6 & -1.575511000 & -1.693553000 & -3.080745000 \\ 6 & -3.035545000 & -3.251732000 & -0.706624000 \\ 6 & -4.427252000 & -1.064822000 & 1.171085000\end{array}$




$\begin{array}{rrrr}6 & -3.861832000 & 1.817532000 & -0.048416000 \\ 6 & -2.127163000 & 1.429383000 & -2.694165000 \\ 7 & 0.033964000 & 0.868085000 & 0.418836000 \\ 6 & -0.054650000 & 2.260347000 & 0.392431000 \\ 6 & 0.269822000 & 3.013270000 & -0.750416000 \\ 6 & -0.479842000 & 2.954600000 & 1.541735000 \\ 6 & 0.168508000 & 4.403411000 & -0.744149000 \\ 6 & -0.565441000 & 4.343579000 & 1.544708000 \\ 6 & -0.245003000 & 5.080803000 & 0.402707000 \\ 1 & -0.288339000 & 0.059476000 & 3.039206000 \\ 1 & -1.941335000 & -2.262183000 & 1.906263000 \\ 1 & -0.791434000 & -1.047502000 & -3.485819000 \\ 1 & -2.298985000 & -1.883218000 & -3.887263000 \\ 1 & -1.112186000 & -2.649079000 & -2.818341000 \\ 1 & -1.212615000 & 1.181490000 & -3.241592000 \\ 1 & -1.964011000 & 2.388081000 & -2.194196000 \\ 1 & -2.926484000 & 1.568789000 & -3.436302000 \\ 1 & -3.176808000 & 2.651645000 & -0.226265000 \\ 1 & -4.053506000 & 1.777597000 & 1.028115000 \\ 1 & -4.813836000 & 2.051907000 & -0.546271000 \\ 1 & -5.474992000 & -1.123904000 & 0.845145000 \\ 1 & -4.362041000 & -0.281501000 & 1.932729000 \\ 1 & -4.184285000 & -2.017351000 & 1.651428000 \\ 1 & -3.066575000 & -3.562478000 & 0.343488000 \\ 1 & -2.188588000 & -3.764245000 & -1.173660000 \\ 1 & -3.951988000 & -3.629125000 & -1.182260000 \\ 1 & 0.050264000 & -2.807963000 & 0.657869000 \\ 1 & 3.916986000 & -1.450578000 & 1.597828000 \\ 1 & 3.3 .000 \\ 1 & -2.038396000 & -0.022951000 & 3.196476000 \\ 1 & 1.790895000 & -2.039096000 & -2.989749000 \\ 1 & 2.176570000 & -3.323511000 & -1.842810000 \\ 1 & 3.445774000 & -2.656035000 & -2.879862000 \\ 1 & 2.433202000 & 1.809671000 & -2.655868000 \\ 1 & 3.444795000 & 0.599469000 & -3.450970000 \\ 1 & 1.708733000 & 0.312811000 & -3.263222000 \\ 1 & 2.964413000 & 2.790649000 & -0.629341000 \\ 1 & 3.606098000 & 2.445971000 & 0.971348000 \\ 1 & 2.384587000 & -0.435971000 \\ 1 & 0.795153000 & 2.505500000 \\ 1 & -0.120054000 & 1.998837000 \\ 1 & -0.952911000 & 2.741272000 \\ 1 & -2.940172000 & 1.767265000 \\ 1 & -3.290131000 & 0.554902000\end{array}$




$\begin{array}{rrrr}1 & 2.929908000 & -3.721438000 & 0.248033000 \\ 1 & -0.734022000 & 2.383359000 & 2.429590000 \\ 1 & -0.889282000 & 4.855026000 & 2.448626000 \\ 1 & -0.317317000 & 6.165097000 & 0.407340000 \\ 1 & 0.417727000 & 4.960327000 & -1.645202000 \\ 1 & 0.586708000 & 2.485397000 & -1.643580000 \\ 6 & -0.987696000 & -1.505873000 & 4.367022000 \\ 1 & -1.831968000 & -2.199060000 & 4.472381000 \\ 1 & -0.070221000 & -2.105501000 & 4.327483000 \\ 1 & -0.948060000 & -0.888573000 & 5.272694000\end{array}$

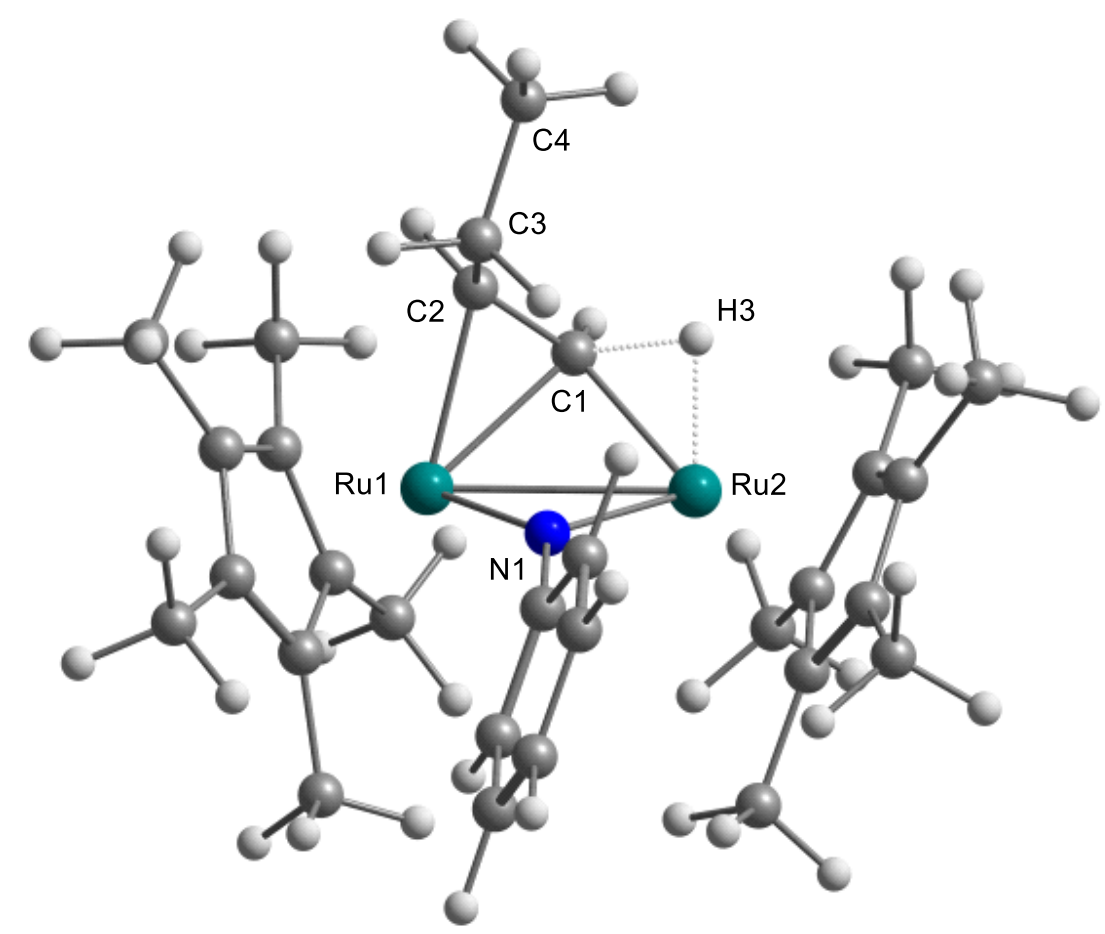

Selected distances (Å)

Ru1 - Ru2 2.81734

Ru1 - C1 2.13678

Ru1-C2 2.17027

Ru1 - N1 1.91497

Ru2 - C1 2.05249

Ru2 - H3 1.61985

Ru2 - N1 1.93991

C1 - C2 1.42573

C2 - C3 1.51384

C3 - C4 1.53380

C1 - H3 1.66713

\section{TS8}

$\begin{array}{lrrr}44 & 1.398733000 & -0.533983000 & 0.192697000 \\ 44 & -1.403601000 & -0.260767000 & 0.094176000 \\ 6 & -1.050471000 & -1.197068000 & 2.019973000 \\ 6 & -0.820481000 & -0.244480000 & 3.173833000 \\ 6 & -0.093210000 & -1.643337000 & 1.062270000 \\ 6 & 2.659660000 & -0.116462000 & -1.612021000 \\ 6 & 3.391791000 & 0.323648000 & -0.468285000 \\ 6 & 3.584638000 & -0.818118000 & 0.384679000 \\ 6 & 3.042615000 & -1.985399000 & -0.274334000 \\ 6 & 2.443164000 & -1.549752000 & -1.491288000 \\ 6 & 2.290479000 & 0.723354000 & -2.796267000 \\ 6 & 3.924826000 & 1.701468000 & -0.230978000\end{array}$




\begin{tabular}{|c|c|c|c|}
\hline 6 & 4.385079000 & -0.826376000 & 1.652377000 \\
\hline 6 & 3.159215000 & -3.400503000 & 0.204001000 \\
\hline 6 & 1.855046000 & -2.434608000 & -2.546923000 \\
\hline 6 & -2.599591000 & -1.146942000 & -1.574835000 \\
\hline 6 & -3.220478000 & -1.501708000 & -0.340853000 \\
\hline 6 & -3.595999000 & -0.280615000 & 0.330786000 \\
\hline 6 & -3.275250000 & 0.826484000 & -0.534953000 \\
\hline 6 & -2.656903000 & 0.292674000 & -1.707050000 \\
\hline 6 & -2.144287000 & -2.100297000 & -2.635874000 \\
\hline 6 & -3.508388000 & -2.894644000 & 0.128389000 \\
\hline 6 & -4.371635000 & -0.192591000 & 1.608900000 \\
\hline 6 & -3.621449000 & 2.261914000 & -0.286337000 \\
\hline 6 & -2.312091000 & 1.042343000 & -2.958527000 \\
\hline 7 & 0.097802000 & 0.892593000 & 0.381673000 \\
\hline 6 & 0.309719000 & 2.267557000 & 0.299083000 \\
\hline 6 & -0.033614000 & 3.009556000 & -0.844441000 \\
\hline 6 & 0.892038000 & 2.949399000 & 1.384920000 \\
\hline 6 & 0.193434000 & 4.383484000 & -0.897075000 \\
\hline 6 & 1.092993000 & 4.324969000 & 1.333774000 \\
\hline 6 & 0.748337000 & 5.053597000 & 0.193129000 \\
\hline 1 & -0.010458000 & 0.444379000 & 2.921781000 \\
\hline 1 & -1.809838000 & -1.947023000 & 2.266732000 \\
\hline 1 & -1.393657000 & -1.644233000 & -3.287580000 \\
\hline 1 & -2.985786000 & -2.414322000 & -3.270769000 \\
\hline 1 & -1.700535000 & -3.001821000 & -2.202877000 \\
\hline 1 & -1.341019000 & 0.742470000 & -3.366945000 \\
\hline 1 & -2.290564000 & 2.122535000 & -2.791474000 \\
\hline 1 & -3.065442000 & 0.850182000 & -3.735901000 \\
\hline 1 & -2.872331000 & 2.939368000 & -0.707453000 \\
\hline 1 & -3.682049000 & 2.476025000 & 0.784734000 \\
\hline 1 & -4.594278000 & 2.515204000 & -0.731458000 \\
\hline 1 & -5.451211000 & -0.272828000 & 1.417734000 \\
\hline 1 & -4.196766000 & 0.757992000 & 2.121678000 \\
\hline 1 & -4.100223000 & -0.995110000 & 2.301890000 \\
\hline 1 & -3.528934000 & -2.962558000 & 1.220747000 \\
\hline 1 & -2.757576000 & -3.605096000 & -0.232403000 \\
\hline 1 & -4.488013000 & -3.236919000 & -0.234582000 \\
\hline 1 & -0.127334000 & -2.702024000 & 0.790864000 \\
\hline 1 & 1.321808000 & -1.059726000 & 1.722919000 \\
\hline 1 & -1.718763000 & 0.367086000 & 3.336023000 \\
\hline 1 & 1.099390000 & -1.910957000 & -3.138592000 \\
\hline 1 & 1.378193000 & -3.318227000 & -2.112619000 \\
\hline 1 & 2.633909000 & -2.784213000 & -3.240033000 \\
\hline
\end{tabular}




$\begin{array}{rrrr}1 & 2.115970000 & 1.764638000 & -2.509899000 \\ 1 & 3.089378000 & 0.712777000 & -3.551689000 \\ 1 & 1.378647000 & 0.355950000 & -3.277402000 \\ 1 & 3.264141000 & 2.468740000 & -0.644551000 \\ 1 & 4.034976000 & 1.909400000 & 0.837249000 \\ 1 & 4.913440000 & 1.822343000 & -0.696883000 \\ 1 & 4.254014000 & 0.102586000 & 2.214930000 \\ 1 & 5.456393000 & -0.938655000 & 1.433362000 \\ 1 & 4.091804000 & -1.652212000 & 2.306764000 \\ 1 & 3.119128000 & -3.462634000 & 1.296261000 \\ 1 & 4.108336000 & -3.851958000 & -0.118095000 \\ 1 & 2.350097000 & -4.024142000 & -0.188773000 \\ 1 & 1.179283000 & 2.377052000 & 2.262147000 \\ 1 & 1.533305000 & 4.831481000 & 2.189833000 \\ 1 & 0.916656000 & 6.126444000 & 0.153077000 \\ 1 & -0.067478000 & 4.933705000 & -1.798786000 \\ 1 & -0.456471000 & 2.481783000 & -1.691752000 \\ 6 & -0.483264000 & -0.997290000 & 4.466928000 \\ 1 & -1.281659000 & -1.698179000 & 4.743042000 \\ 1 & 0.440547000 & -1.577410000 & 4.351919000 \\ 1 & -0.344965000 & -0.302586000 & 5.304678000\end{array}$

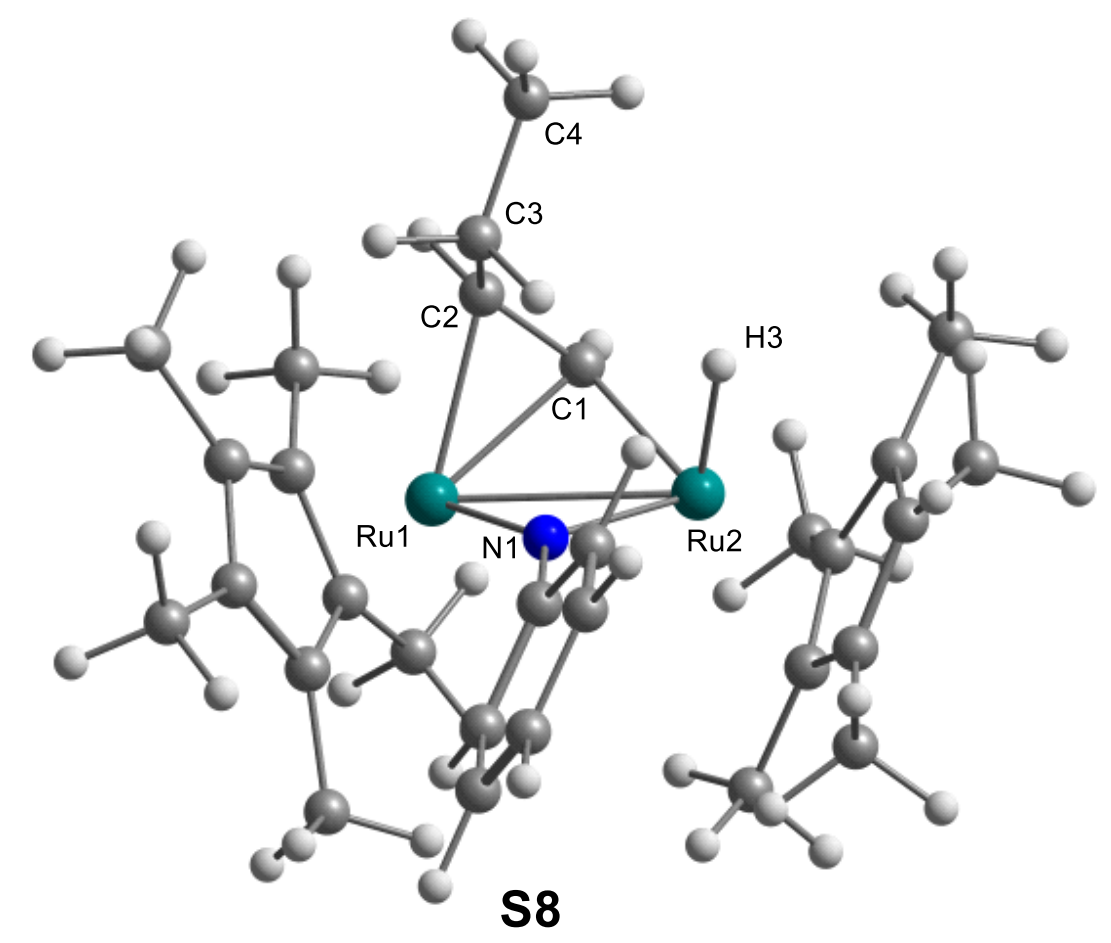

Selected distances (A)

Ru1 - Ru2 2.79090

Ru1 - C1 2.15396

Ru1-C2 2.19254

Ru1 - N1 1.89443

Ru2 - C1 2.00129

Ru2 - H3 1.59113

Ru2 - N1 1.95442

C1 - C2 1.42022

C2 - C3 1.51294

C3 - C4 1.53384

$\begin{array}{rrrr}44 & 1.385014000 & -0.504336000 & 0.228553000 \\ 44 & -1.389232000 & -0.223865000 & 0.110200000\end{array}$




\begin{tabular}{|c|c|c|c|}
\hline 6 & -0.990372000 & -1.172167000 & 2.046397000 \\
\hline 6 & -0.769890000 & -0.196128000 & 3.181181000 \\
\hline 6 & -0.052393000 & -1.610582000 & 1.074276000 \\
\hline 6 & 2.428423000 & -0.696831000 & -1.801278000 \\
\hline 6 & 3.174184000 & 0.268524000 & -1.058204000 \\
\hline 6 & 3.622749000 & -0.364600000 & 0.141098000 \\
\hline 6 & 3.199901000 & -1.755450000 & 0.115139000 \\
\hline 6 & 2.450266000 & -1.955369000 & -1.085777000 \\
\hline 6 & 1.822038000 & -0.477391000 & -3.152969000 \\
\hline 6 & 3.459678000 & 1.678167000 & -1.474834000 \\
\hline 6 & 4.530004000 & 0.248292000 & 1.164652000 \\
\hline 6 & 3.614072000 & -2.815772000 & 1.090005000 \\
\hline 6 & 1.925198000 & -3.265248000 & -1.588752000 \\
\hline 6 & -2.577409000 & -1.150870000 & -1.559353000 \\
\hline 6 & -3.179523000 & -1.524250000 & -0.322829000 \\
\hline 6 & -3.582815000 & -0.317235000 & 0.355447000 \\
\hline 6 & -3.295292000 & 0.801164000 & -0.509107000 \\
\hline 6 & -2.671485000 & 0.285381000 & -1.688522000 \\
\hline 6 & -2.096122000 & -2.089391000 & -2.621601000 \\
\hline 6 & -3.417108000 & -2.925469000 & 0.150190000 \\
\hline 6 & -4.356739000 & -0.253943000 & 1.636121000 \\
\hline 6 & -3.692381000 & 2.222522000 & -0.256073000 \\
\hline 6 & -2.352123000 & 1.041318000 & -2.943553000 \\
\hline 7 & 0.081491000 & 0.947421000 & 0.342461000 \\
\hline 6 & 0.310146000 & 2.318519000 & 0.272223000 \\
\hline 6 & -0.164324000 & 3.103401000 & -0.792620000 \\
\hline 6 & 1.047322000 & 2.951686000 & 1.292382000 \\
\hline 6 & 0.080508000 & 4.474261000 & -0.829512000 \\
\hline 6 & 1.263527000 & 4.325216000 & 1.260740000 \\
\hline 6 & 0.784821000 & 5.097826000 & 0.200076000 \\
\hline 1 & 0.003261000 & 0.523953000 & 2.904908000 \\
\hline 1 & -1.752875000 & -1.915309000 & 2.308895000 \\
\hline 1 & -1.340869000 & -1.616991000 & -3.255954000 \\
\hline 1 & -2.923423000 & -2.406439000 & -3.273256000 \\
\hline 1 & -1.651555000 & -2.990473000 & -2.188582000 \\
\hline 1 & -1.354198000 & 0.804745000 & -3.327687000 \\
\hline 1 & -2.409822000 & 2.122664000 & -2.791875000 \\
\hline 1 & -3.074208000 & 0.788280000 & -3.732786000 \\
\hline 1 & -2.976409000 & 2.929390000 & -0.685880000 \\
\hline 1 & -3.746169000 & 2.433360000 & 0.815939000 \\
\hline 1 & -4.680320000 & 2.438253000 & -0.687569000 \\
\hline 1 & -5.434990000 & -0.353151000 & 1.446357000 \\
\hline 1 & -4.198356000 & 0.695503000 & 2.156148000 \\
\hline
\end{tabular}




$\begin{array}{rrrr}1 & -4.068123000 & -1.056613000 & 2.321702000 \\ 1 & -3.414012000 & -2.994568000 & 1.242494000 \\ 1 & -2.653562000 & -3.613823000 & -0.225788000 \\ 1 & -4.393279000 & -3.294515000 & -0.195112000 \\ 1 & -0.143479000 & -2.660074000 & 0.768284000 \\ 1 & 1.692678000 & -0.384065000 & 1.785019000 \\ 1 & -1.691363000 & 0.375305000 & 3.361769000 \\ 1 & 1.071162000 & -3.126279000 & -2.258839000 \\ 1 & 1.595752000 & -3.906159000 & -0.764439000 \\ 1 & 2.696610000 & -3.815516000 & -2.146010000 \\ 1 & 1.529303000 & 0.566654000 & -3.298668000 \\ 1 & 2.538095000 & -0.733783000 & -3.947144000 \\ 1 & 0.934153000 & -1.099208000 & -3.298619000 \\ 1 & 2.630441000 & 2.107217000 & -2.045843000 \\ 1 & 3.620251000 & 2.327268000 & -0.609271000 \\ 1 & 4.360253000 & 1.730002000 & -2.102991000 \\ 1 & 4.338968000 & 1.319114000 & 1.280872000 \\ 1 & 5.582538000 & 0.126064000 & 0.872188000 \\ 1 & 4.400890000 & -0.218923000 & 2.144979000 \\ 1 & 3.732464000 & -2.408063000 & 2.098309000 \\ 1 & 4.572313000 & -3.269238000 & 0.798271000 \\ 1 & 2.870965000 & -3.616688000 & 1.149590000 \\ 1 & 1.432616000 & 2.342227000 & 2.104688000 \\ 1 & 1.820191000 & 4.795811000 & 2.068108000 \\ 1 & 0.966113000 & 6.168940000 & 0.173149000 \\ 1 & -0.282360000 & 5.058639000 & -1.672460000 \\ 1 & -0.695572000 & 2.611437000 & -1.599116000 \\ 6 & -0.365919000 & -0.920816000 & 4.471261000 \\ 1 & -1.123120000 & -1.656074000 & 4.773265000 \\ 1 & 0.580942000 & -1.456283000 & 4.333807000 \\ 1 & -0.240402000 & -0.212300000 & 5.299589000\end{array}$




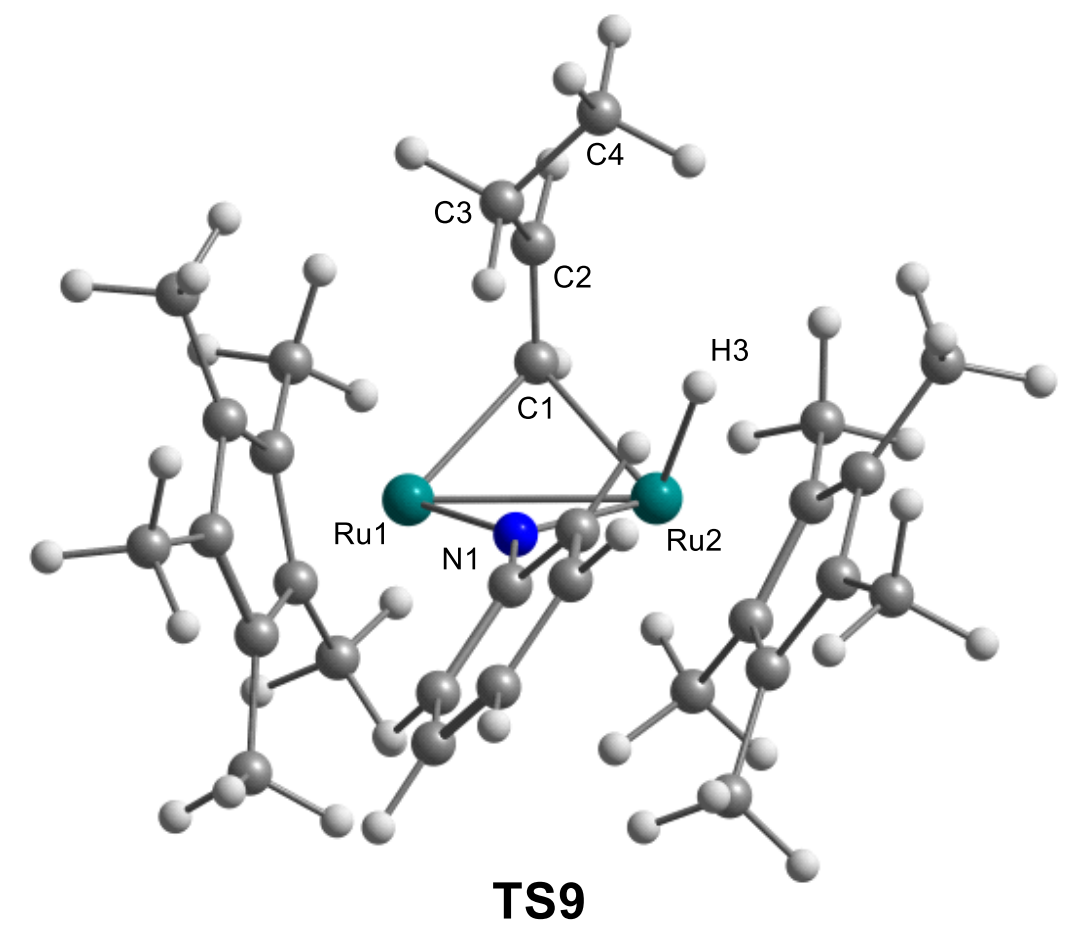

Selected distances (A)

Ru1-Ru2 2.68358

Ru1 - C1 2.14015

Ru1 - N1 1.89387

Ru2 - C1 2.20757

Ru2 - H3 1.59069

Ru2 - N1 1.93029

C1 - C2 1.37215

C2 - C3 1.49892

C3 - C4 1.53221

$\begin{array}{lrrr}44 & 1.340001000 & -0.351828000 & 0.064206000 \\ 44 & -1.340881000 & -0.235483000 & 0.033603000 \\ 6 & -0.106917000 & -1.643596000 & 2.443849000 \\ 6 & -0.229252000 & -0.476977000 & 3.377016000 \\ 6 & -0.126038000 & -1.658960000 & 1.071920000 \\ 6 & 2.530787000 & -0.013467000 & -1.729085000 \\ 6 & 3.372452000 & 0.188542000 & -0.588821000 \\ 6 & 3.468208000 & -1.087338000 & 0.102334000 \\ 6 & 2.737187000 & -2.067430000 & -0.635103000 \\ 6 & 2.134504000 & -1.413005000 & -1.751527000 \\ 6 & 2.231167000 & 0.996603000 & -2.793407000 \\ 6 & 4.148298000 & 1.428378000 & -0.267229000 \\ 6 & 4.341008000 & -1.369448000 & 1.287700000 \\ 6 & 2.646322000 & -3.524751000 & -0.307302000 \\ 6 & 1.358678000 & -2.071795000 & -2.849503000 \\ 6 & -2.776827000 & -1.256893000 & -1.362999000 \\ 6 & -3.054618000 & -1.714132000 & -0.048071000 \\ 6 & -3.355509000 & -0.566812000 & 0.771618000 \\ 6 & -3.356732000 & 0.607471000 & -0.081977000 \\ 6 & -2.979521000 & 0.179761000 & -1.393441000 \\ 6 & -2.500997000 & -2.106117000 & -2.563990000 \\ 6 & -3.055025000 & -3.139261000 & 0.410808000 \\ 6 & -3.816337000 & -0.599009000 & 2.195602000 \\ 6 & -3.804414000 & 1.974910000 & 0.333262000 \\ 6 & -2.977297000 & 0.999981000 & -2.647810000\end{array}$




\begin{tabular}{|c|c|c|c|}
\hline 7 & 0.030788000 & 1.061160000 & 0.188470000 \\
\hline 6 & 0.184397000 & 2.440947000 & 0.162361000 \\
\hline 6 & -0.511181000 & 3.232968000 & -0.768974000 \\
\hline 6 & 1.046866000 & 3.082025000 & 1.073037000 \\
\hline 6 & -0.350886000 & 4.615784000 & -0.785484000 \\
\hline 6 & 1.181505000 & 4.466366000 & 1.065275000 \\
\hline 6 & 0.487511000 & 5.244304000 & 0.135687000 \\
\hline 1 & -0.250610000 & 0.455366000 & 2.804372000 \\
\hline 1 & -0.020979000 & -2.605881000 & 2.969532000 \\
\hline 1 & -1.868896000 & -1.584275000 & -3.288684000 \\
\hline 1 & -3.437450000 & -2.371185000 & -3.076796000 \\
\hline 1 & -1.998341000 & -3.040162000 & -2.296209000 \\
\hline 1 & -2.082436000 & 0.818866000 & -3.252992000 \\
\hline 1 & -3.026382000 & 2.070840000 & -2.431496000 \\
\hline 1 & -3.850314000 & 0.755399000 & -3.270024000 \\
\hline 1 & -3.331581000 & 2.758827000 & -0.265417000 \\
\hline 1 & -3.549801000 & 2.173413000 & 1.379175000 \\
\hline 1 & -4.893810000 & 2.083607000 & 0.229645000 \\
\hline 1 & -4.914148000 & -0.639210000 & 2.251902000 \\
\hline 1 & -3.489333000 & 0.291941000 & 2.740454000 \\
\hline 1 & -3.425040000 & -1.472816000 & 2.724205000 \\
\hline 1 & -2.709940000 & -3.229731000 & 1.445205000 \\
\hline 1 & -2.402388000 & -3.763062000 & -0.208093000 \\
\hline 1 & -4.066539000 & -3.565522000 & 0.356848000 \\
\hline 1 & -0.094303000 & -2.668595000 & 0.650639000 \\
\hline 1 & 1.916481000 & 0.012625000 & 1.501260000 \\
\hline 1 & -1.201737000 & -0.550039000 & 3.891757000 \\
\hline 1 & 0.599059000 & -1.401540000 & -3.259700000 \\
\hline 1 & 0.849141000 & -2.974759000 & -2.502408000 \\
\hline 1 & 2.027795000 & -2.363707000 & -3.672277000 \\
\hline 1 & 2.226021000 & 2.012636000 & -2.388787000 \\
\hline 1 & 2.983956000 & 0.955827000 & -3.593632000 \\
\hline 1 & 1.251880000 & 0.819627000 & -3.248263000 \\
\hline 1 & 3.596813000 & 2.330105000 & -0.548342000 \\
\hline 1 & 4.361778000 & 1.499693000 & 0.803684000 \\
\hline 1 & 5.110574000 & 1.441575000 & -0.799316000 \\
\hline 1 & 4.473010000 & -0.479770000 & 1.909688000 \\
\hline 1 & 5.337177000 & -1.698124000 & 0.959917000 \\
\hline 1 & 3.921317000 & -2.156354000 & 1.920927000 \\
\hline 1 & 2.684755000 & -3.694306000 & 0.772899000 \\
\hline 1 & 3.475534000 & -4.084112000 & -0.762492000 \\
\hline 1 & 1.713762000 & -3.962945000 & -0.676112000 \\
\hline 1 & 1.590308000 & 2.467665000 & 1.785260000 \\
\hline
\end{tabular}




$\begin{array}{rrrr}1 & 1.839956000 & 4.942300000 & 1.788611000 \\ 1 & 0.602604000 & 6.324909000 & 0.127357000 \\ 1 & -0.886985000 & 5.206921000 & -1.524905000 \\ 1 & -1.151684000 & 2.734735000 & -1.488270000 \\ 6 & 0.872819000 & -0.439789000 & 4.440844000 \\ 1 & 0.915879000 & -1.379084000 & 5.007332000 \\ 1 & 1.853221000 & -0.287337000 & 3.974711000 \\ 1 & 0.703905000 & 0.373655000 & 5.156407000\end{array}$

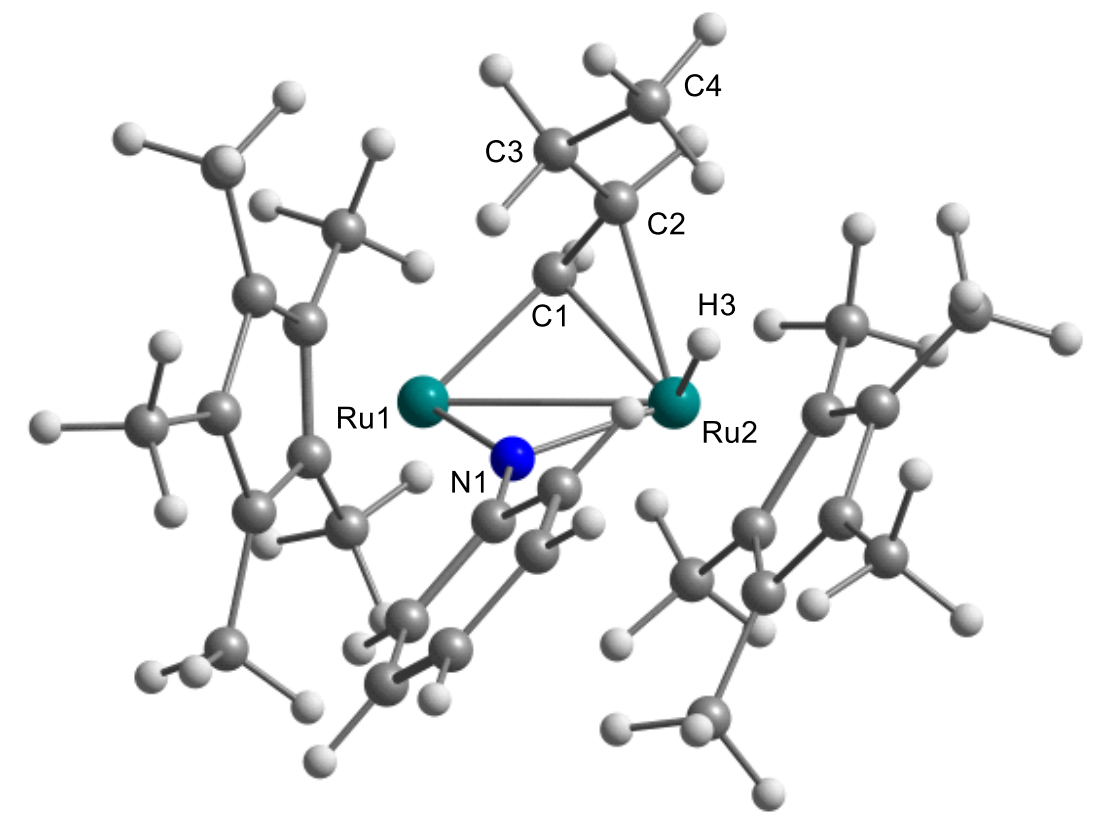

Selected distances (Å)

Ru1-Ru2 2.74342

Ru1 - C1 2.01035

Ru1 - N1 1.85225

Ru2 - C1 2.11816

Ru2 - C2 2.22068

Ru2 - H3 1.58180

Ru2 - N1 2.05605

C1 - C2 1.41557

C2 - C3 1.51719

C3 - C4 1.52660

\section{S9}

$\begin{array}{lrrr}44 & 1.417318000 & -0.357087000 & 0.192511000 \\ 44 & -1.323437000 & -0.277166000 & 0.101673000 \\ 6 & 0.715087000 & -1.054049000 & 2.180610000 \\ 6 & 0.315761000 & -0.020524000 & 3.217059000 \\ 6 & -0.101151000 & -1.508578000 & 1.117124000 \\ 6 & 2.363335000 & -0.114451000 & -1.860782000 \\ 6 & 3.312133000 & 0.171963000 & -0.827872000 \\ 6 & 3.493259000 & -1.034607000 & -0.041802000 \\ 6 & 2.663896000 & -2.057269000 & -0.615714000 \\ 6 & 1.971347000 & -1.489742000 & -1.736878000 \\ 6 & 1.916918000 & 0.827174000 & -2.935690000 \\ 6 & 4.086692000 & 1.446812000 & -0.679990000 \\ 6 & 4.512033000 & -1.236029000 & 1.039106000 \\ 6 & 2.631357000 & -3.495522000 & -0.196553000 \\ 6 & 1.091661000 & -2.235383000 & -2.691620000 \\ 6 & -2.884449000 & -1.455898000 & -1.121381000\end{array}$




$\begin{array}{lrrr}6 & -2.958394000 & -1.874250000 & 0.233241000 \\ 6 & -3.232057000 & -0.717931000 & 1.049850000 \\ 6 & -3.415840000 & 0.418006000 & 0.162578000 \\ 6 & -3.185065000 & -0.044074000 & -1.170252000 \\ 6 & -2.709744000 & -2.336642000 & -2.318256000 \\ 6 & -2.813668000 & -3.279406000 & 0.729418000 \\ 6 & -3.513105000 & -0.730184000 & 2.520851000 \\ 6 & -3.895844000 & 1.774689000 & 0.578173000 \\ 6 & -3.376933000 & 0.733034000 & -2.437952000 \\ 7 & -0.055782000 & 1.073246000 & 0.085360000 \\ 6 & 0.024764000 & 2.447050000 & -0.042044000 \\ 6 & -0.813755000 & 3.132138000 & -0.946087000 \\ 6 & 0.942692000 & 3.211338000 & 0.708780000 \\ 6 & -0.747618000 & 4.515410000 & -1.079084000 \\ 6 & 0.989179000 & 4.595480000 & 0.581524000 \\ 6 & 0.148214000 & 5.261611000 & -0.312301000 \\ 1 & -0.214617000 & 0.805821000 & 2.734638000 \\ 1 & 1.396575000 & -1.805387000 & 2.600061000 \\ 1 & -2.206676000 & -1.811315000 & -3.135507000 \\ 1 & -3.685073000 & -2.675629000 & -2.697462000 \\ 1 & -2.122789000 & -3.229603000 & -2.084384000 \\ 1 & -2.544430000 & 0.594548000 & -3.136359000 \\ 1 & -3.477539000 & 1.804423000 & -2.243683000 \\ 1 & -4.293326000 & 0.408616000 & -2.951328000 \\ 1 & -3.485193000 & 2.565429000 & -0.056707000 \\ 1 & -3.595873000 & 2.001737000 & 1.605561000 \\ 1 & -4.992490000 & 1.836971000 & 0.531006000 \\ 1 & -4.578473000 & -0.919519000 & 2.717997000 \\ 1 & -3.253511000 & 0.225663000 & 2.985436000 \\ 1 & -2.936510000 & -1.508060000 & 3.029988000 \\ 1 & -2.398647000 & -3.309035000 & 1.741457000 \\ 1 & -2.155075000 & -3.871818000 & 0.085619000 \\ 1 & -3.788443000 & -3.785586000 & 0.755107000 \\ 1 & -0.085532000 & -2.575093000 & 0.872513000 \\ 1 & 1.991200000 & 0.599085000 & 1.314333000 \\ 1 & -0.410079000 & -0.499107000 & 3.895465000 \\ 1 & 0.387739000 & -1.565989000 & -3.192471000 \\ 1 & 0.507892000 & -3.009912000 & -2.186682000 \\ 1 & 1.695374000 & -2.727515000 & -3.468139000 \\ 1 & 2.021985000 & 1.869198000 & -2.622053000 \\ 1 & 0.864183000 & 0.667347000 & -3.188847000 \\ 1 & & 2.322025000 & -0.892593000\end{array}$




$\begin{array}{rrrr}1 & 4.475020000 & 1.560725000 & 0.336164000 \\ 1 & 4.943487000 & 1.464805000 & -1.368189000 \\ 1 & 4.686609000 & -0.314371000 & 1.601419000 \\ 1 & 5.474134000 & -1.558918000 & 0.616645000 \\ 1 & 4.191383000 & -1.999138000 & 1.754334000 \\ 1 & 2.783445000 & -3.603091000 & 0.881902000 \\ 1 & 3.422063000 & -4.069621000 & -0.699646000 \\ 1 & 1.675499000 & -3.967078000 & -0.445188000 \\ 1 & 1.603736000 & 2.693214000 & 1.396704000 \\ 1 & 1.696599000 & 5.160370000 & 1.184951000 \\ 1 & 0.197217000 & 6.342218000 & -0.415990000 \\ 1 & -1.398433000 & 5.013738000 & -1.794724000 \\ 1 & -1.491118000 & 2.546216000 & -1.558431000 \\ 6 & 1.477179000 & 0.502529000 & 4.058503000 \\ 1 & 1.998900000 & -0.315968000 & 4.571578000 \\ 1 & 2.213571000 & 1.023870000 & 3.435495000 \\ 1 & 1.125435000 & 1.203440000 & 4.824745000\end{array}$

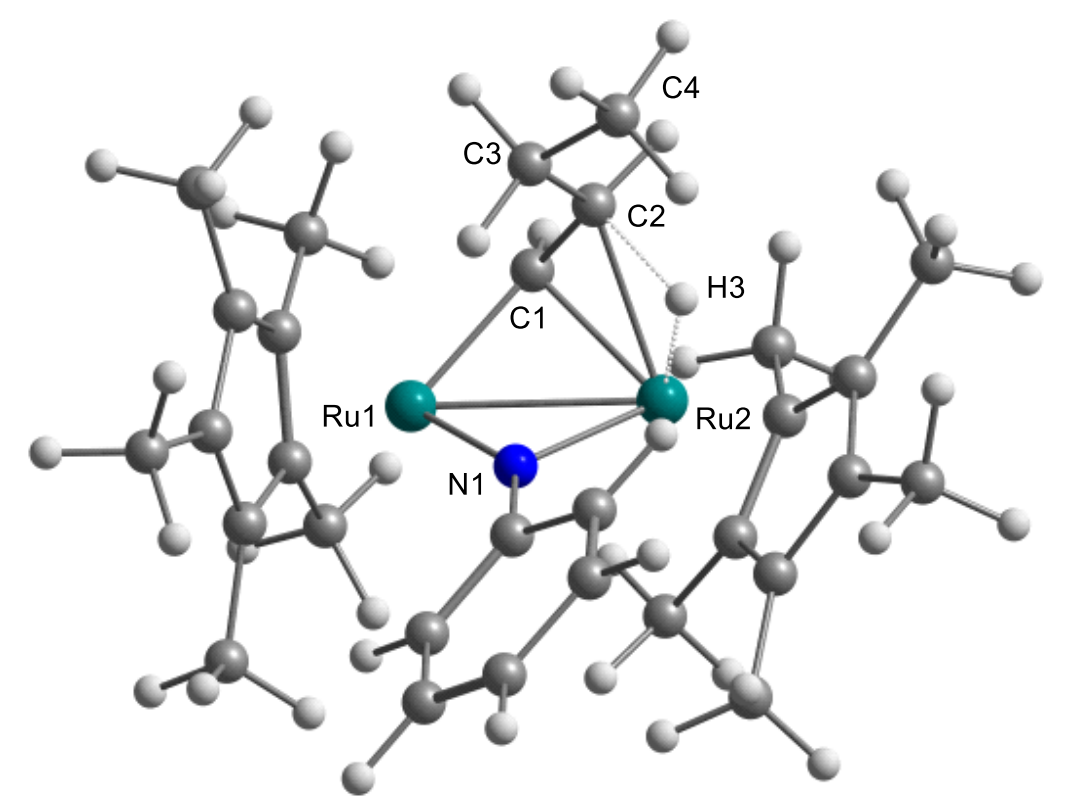

Selected distances (A)

Ru1-Ru2 2.73390

Ru1 - C1 2.01195

Ru1 - N1 1.86473

Ru2 - C1 2.09698

Ru2 - C2 2.26524

Ru2 - H3 1.62861

Ru2 - N1 2.04507

C1 - C2 1.43808

C2 - C3 1.52438

C3 - C4 1.52636

C2 - H3 1.60244

\section{TS10}

$\begin{array}{lrcc}44 & 1.375865000 & -0.452714000 & 0.176235000 \\ 44 & -1.348864000 & -0.241010000 & 0.103776000 \\ 6 & 0.629611000 & -0.894999000 & 2.268790000 \\ 6 & 0.122964000 & 0.165613000 & 3.239437000 \\ 6 & -0.163841000 & -1.441002000 & 1.200896000 \\ 6 & 2.617646000 & -0.017668000 & -1.638685000 \\ 6 & 3.460075000 & -0.108211000 & -0.483730000\end{array}$




\begin{tabular}{|c|c|c|c|}
\hline 6 & 3.328520000 & -1.450897000 & 0.052314000 \\
\hline 6 & 2.424153000 & -2.178670000 & -0.791166000 \\
\hline 6 & 1.980733000 & -1.292239000 & -1.832382000 \\
\hline 6 & 2.495853000 & 1.166366000 & -2.546982000 \\
\hline 6 & 4.428942000 & 0.936893000 & -0.018624000 \\
\hline 6 & 4.130508000 & -2.018180000 & 1.184402000 \\
\hline 6 & 2.085812000 & -3.633968000 & -0.676704000 \\
\hline 6 & 1.112384000 & -1.668293000 & -2.992135000 \\
\hline 6 & -2.895081000 & -1.365932000 & -1.159264000 \\
\hline 6 & -3.026330000 & -1.774323000 & 0.196127000 \\
\hline 6 & -3.300821000 & -0.604887000 & 0.992631000 \\
\hline 6 & -3.428486000 & 0.527476000 & 0.089783000 \\
\hline 6 & -3.171642000 & 0.049642000 & -1.230153000 \\
\hline 6 & -2.687139000 & -2.258016000 & -2.342658000 \\
\hline 6 & -2.933783000 & -3.179656000 & 0.704175000 \\
\hline 6 & -3.642277000 & -0.594763000 & 2.451105000 \\
\hline 6 & -3.894695000 & 1.895256000 & 0.483850000 \\
\hline 6 & -3.297929000 & 0.819173000 & -2.510477000 \\
\hline 7 & -0.005074000 & 1.050987000 & 0.057007000 \\
\hline 6 & 0.160039000 & 2.410483000 & -0.109458000 \\
\hline 6 & -0.684335000 & 3.155769000 & -0.958637000 \\
\hline 6 & 1.190645000 & 3.102326000 & 0.563536000 \\
\hline 6 & -0.513747000 & 4.527437000 & -1.113302000 \\
\hline 6 & 1.341187000 & 4.477240000 & 0.417408000 \\
\hline 6 & 0.493544000 & 5.203122000 & -0.422256000 \\
\hline 1 & -0.388354000 & 0.952867000 & 2.677758000 \\
\hline 1 & 1.285203000 & -1.616920000 & 2.771466000 \\
\hline 1 & -2.108936000 & -1.758902000 & -3.126016000 \\
\hline 1 & -3.650799000 & -2.555005000 & -2.782198000 \\
\hline 1 & -2.156886000 & -3.175184000 & -2.069127000 \\
\hline 1 & -2.443387000 & 0.654959000 & -3.175876000 \\
\hline 1 & -3.381266000 & 1.894649000 & -2.330782000 \\
\hline 1 & -4.201477000 & 0.510907000 & -3.055727000 \\
\hline 1 & -3.497195000 & 2.670069000 & -0.177941000 \\
\hline 1 & -3.572839000 & 2.145721000 & 1.499288000 \\
\hline 1 & -4.991972000 & 1.960746000 & 0.458078000 \\
\hline 1 & -4.722106000 & -0.735365000 & 2.606360000 \\
\hline 1 & -3.360019000 & 0.352140000 & 2.921126000 \\
\hline 1 & -3.123403000 & -1.394645000 & 2.988018000 \\
\hline 1 & -2.566892000 & -3.212831000 & 1.734680000 \\
\hline 1 & -2.256569000 & -3.787115000 & 0.094589000 \\
\hline 1 & -3.917941000 & -3.668059000 & 0.687398000 \\
\hline 1 & -0.206722000 & -2.529392000 & 1.104569000 \\
\hline
\end{tabular}




$\begin{array}{cccc}1 & 1.722923000 & 0.108952000 & 1.665007000 \\ 1 & -0.640792000 & -0.319233000 & 3.865700000 \\ 1 & 0.525859000 & -0.816101000 & -3.346048000 \\ 1 & 0.411245000 & -2.463710000 & -2.726266000 \\ 1 & 1.722738000 & -2.026858000 & -3.834092000 \\ 1 & 2.607440000 & 2.105977000 & -1.999056000 \\ 1 & 3.265965000 & 1.137595000 & -3.330579000 \\ 1 & 1.519783000 & 1.192943000 & -3.040008000 \\ 1 & 4.053760000 & 1.945875000 & -0.214523000 \\ 1 & 4.621102000 & 0.858767000 & 1.055875000 \\ 1 & 5.394292000 & 0.834941000 & -0.535237000 \\ 1 & 4.362067000 & -1.253345000 & 1.932301000 \\ 1 & 5.084453000 & -2.429352000 & 0.825321000 \\ 1 & 3.595664000 & -2.825617000 & 1.695084000 \\ 1 & 2.187057000 & -3.989765000 & 0.353274000 \\ 1 & 2.751656000 & -4.244494000 & -1.302860000 \\ 1 & 1.057751000 & -3.833790000 & -0.994972000 \\ 1 & 1.854101000 & 2.530010000 & 1.205572000 \\ 1 & 2.134257000 & 4.987175000 & 0.960538000 \\ 1 & 0.621639000 & 6.275497000 & -0.542804000 \\ 1 & -1.171684000 & 5.074063000 & -1.785959000 \\ 1 & -1.452319000 & 2.625187000 & -1.511213000 \\ 6 & 1.206531000 & 0.754189000 & 4.139019000 \\ 1 & 1.713132000 & -0.025633000 & 4.722424000 \\ 1 & 1.970083000 & 1.277605000 & 3.549848000 \\ 1 & 0.782590000 & 1.475948000 & 4.846298000\end{array}$




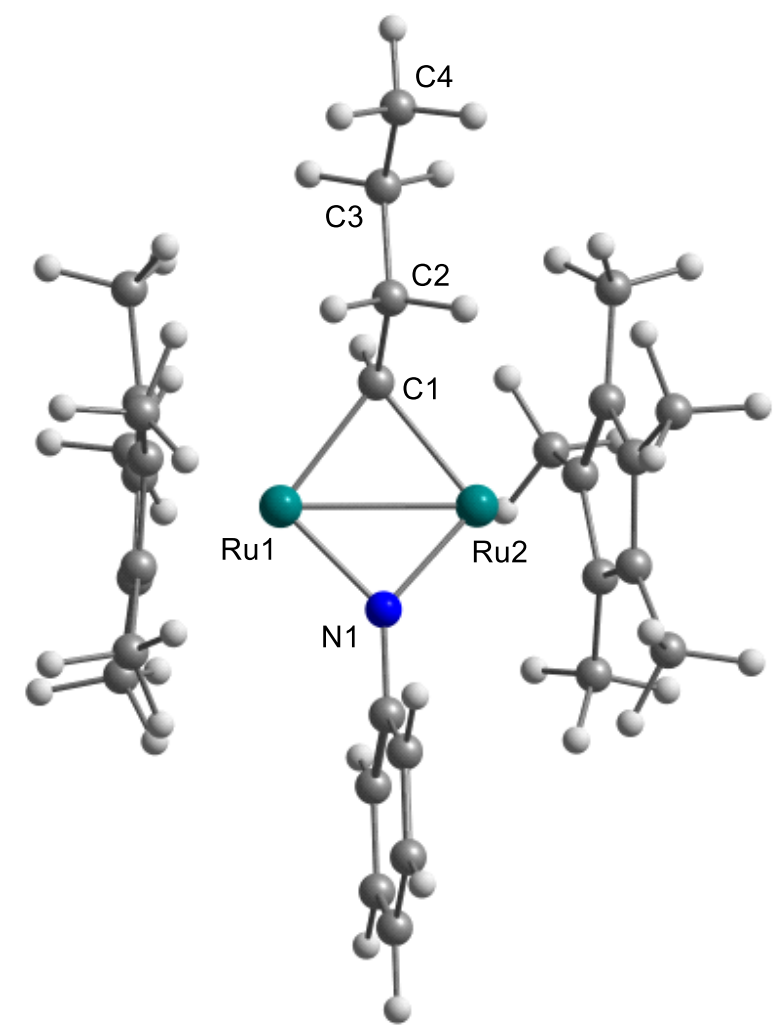

Selected distances (A)

Ru1-Ru2 2.60300

Ru1 - C1 2.08017

Ru1 - N1 1.90145

Ru2 - C1 2.08017

Ru2 - N1 1.90146

C1 - C2 1.53235

C2 - C3 1.53455

C3 - C4 1.52804

9

$\begin{array}{lrrr}44 & -1.301496000 & -0.145177000 & 0.066863000 \\ 44 & 1.301508000 & -0.145052000 & 0.066860000 \\ 6 & 0.000143000 & -2.809434000 & -0.950350000 \\ 6 & 0.000180000 & -4.278969000 & -0.508409000 \\ 6 & 0.000083000 & -1.764512000 & 0.170474000 \\ 6 & -3.087192000 & 0.741785000 & 0.956969000 \\ 6 & -3.281097000 & 0.663011000 & -0.455173000 \\ 6 & -3.242613000 & -0.737825000 & -0.831799000 \\ 6 & -3.092244000 & -1.509967000 & 0.363250000 \\ 6 & -2.922038000 & -0.609847000 & 1.464497000 \\ 6 & -3.135251000 & 1.980355000 & 1.796065000 \\ 6 & -3.561195000 & 1.803055000 & -1.384853000 \\ 6 & -3.522266000 & -1.267073000 & -2.204188000 \\ 6 & -3.208376000 & -2.997390000 & 0.466211000 \\ 6 & -2.795615000 & -0.995156000 & 2.905412000 \\ 6 & 3.087214000 & 0.742225000 & 0.956670000 \\ 6 & 2.922110000 & -0.609262000 & 1.464591000 \\ 6 & 3.092310000 & -1.509698000 & 0.363605000 \\ 6 & 3.242617000 & -0.737904000 & -0.831677000 \\ 6 & 3.281049000 & 0.663050000 & -0.455456000 \\ 6 & 3.135240000 & 1.981046000 & 1.795397000 \\ 6 & 2.795740000 & -0.994162000 & 2.905620000\end{array}$




\begin{tabular}{|c|c|c|c|}
\hline 6 & 3.208470000 & -2.997087000 & 0.467036000 \\
\hline 6 & 3.522304000 & -1.267528000 & -2.203916000 \\
\hline 6 & 3.561113000 & 1.802845000 & -1.385451000 \\
\hline 7 & -0.000055000 & 1.212689000 & -0.212394000 \\
\hline 6 & -0.000116000 & 2.591642000 & -0.404367000 \\
\hline 6 & -0.000241000 & 3.476346000 & 0.688366000 \\
\hline 6 & -0.000052000 & 3.126278000 & -1.704866000 \\
\hline 6 & -0.000308000 & 4.854130000 & 0.481900000 \\
\hline 6 & -0.000119000 & 4.504754000 & -1.901523000 \\
\hline 6 & -0.000251000 & 5.377729000 & -0.811894000 \\
\hline 1 & 0.874074000 & -4.472642000 & 0.125762000 \\
\hline 1 & -0.865916000 & -2.633508000 & -1.606328000 \\
\hline 1 & 2.795477000 & 2.860308000 & 1.240609000 \\
\hline 1 & 4.161095000 & 2.176228000 & 2.139175000 \\
\hline 1 & 2.502106000 & 1.886073000 & 2.683104000 \\
\hline 1 & 3.111662000 & 2.734788000 & -1.030748000 \\
\hline 1 & 3.161424000 & 1.609066000 & -2.385808000 \\
\hline 1 & 4.643071000 & 1.969510000 & -1.486984000 \\
\hline 1 & 3.089217000 & -0.624055000 & -2.975970000 \\
\hline 1 & 3.111181000 & -2.271555000 & -2.342853000 \\
\hline 1 & 4.605090000 & -1.325416000 & -2.388229000 \\
\hline 1 & 4.255970000 & -3.279197000 & 0.645591000 \\
\hline 1 & 2.888305000 & -3.499894000 & -0.449493000 \\
\hline 1 & 2.616050000 & -3.396804000 & 1.294743000 \\
\hline 1 & 2.243521000 & -1.932091000 & 3.020759000 \\
\hline 1 & 2.261886000 & -0.228505000 & 3.476517000 \\
\hline 1 & 3.783284000 & -1.129723000 & 3.370682000 \\
\hline 1 & 0.866224000 & -2.633452000 & -1.606283000 \\
\hline 1 & 0.000103000 & -2.256135000 & 1.156615000 \\
\hline 1 & -0.873714000 & -4.472688000 & 0.125749000 \\
\hline 1 & -2.261750000 & -0.229657000 & 3.476507000 \\
\hline 1 & -2.243373000 & -1.933109000 & 3.020263000 \\
\hline 1 & -3.783139000 & -1.130867000 & 3.370473000 \\
\hline 1 & -2.795486000 & 2.859789000 & 1.241548000 \\
\hline 1 & -4.161116000 & 2.175419000 & 2.139878000 \\
\hline 1 & -2.502137000 & 1.885120000 & 2.683758000 \\
\hline 1 & -3.112117000 & 2.734996000 & -1.029677000 \\
\hline 1 & -3.161137000 & 1.609752000 & -2.385155000 \\
\hline 1 & -4.643169000 & 1.969453000 & -1.486661000 \\
\hline 1 & -3.089412000 & -0.623224000 & -2.976057000 \\
\hline 1 & -4.605050000 & -1.325191000 & -2.388438000 \\
\hline 1 & -3.110878000 & -2.270943000 & -2.343485000 \\
\hline 1 & -2.887925000 & -3.499921000 & -0.450371000 \\
\hline
\end{tabular}




$\begin{array}{lccc}1 & -4.255917000 & -3.279590000 & 0.644378000 \\ 1 & -2.616185000 & -3.397319000 & 1.293976000 \\ 1 & 0.000050000 & 2.438513000 & -2.546091000 \\ 1 & -0.000070000 & 4.900039000 & -2.914867000 \\ 1 & -0.000305000 & 6.453008000 & -0.969368000 \\ 1 & -0.000404000 & 5.523250000 & 1.339566000 \\ 1 & -0.000276000 & 3.059894000 & 1.691571000 \\ 6 & 0.000212000 & -5.255160000 & -1.683978000 \\ 1 & -0.883150000 & -5.112095000 & -2.319599000 \\ 1 & 0.883571000 & -5.112043000 & -2.319591000 \\ 1 & 0.000240000 & -6.297971000 & -1.345158000\end{array}$




\section{References.}

(1) Takemoto, S.; Kobayashi, T.; Ito, T.; Inui, A.; Karitani, K.; Katagiri, S.; Masuhara, Y.; Matsuzaka, H. Synthesis and Reactivity of Coordinatively Unsaturated Dinuclear Ruthenium Bridging Imido Complexes. Organometallics 2011, 30, 2160-2172.

(2) Miyatake, K.; Endo, K.; Tsuchida, E. Solubilization of Poly(phenylene sulfilde) via Sulfonium Formation by Alkylation. Macromolecules 1999, 32, 8786-8790.

(3) Trost, B. M.; Bogdanowicz, M. J. Preparation of Cyclopropyldiphenylsulfonium and 2Methylcyclopropyldiphenylsulfonium Fluoroborate and Their Ylides. Stereochemistry of Sulfur Ylides. J. Am. Chem. Soc. 1973, 95, 5298-5307.

(4) Jarek, R. L.; Flesher, R. J.; Shin, S. K. Kinetics of Internal Rotation of $N, N$ Dimethylacetamide: A Spin-Saturation Transfer Experiment. J. Chem. Educ. 1997, 74, 978982.

(5) PROCESS AUTO, Automatic Data Acquisition and Processing Package for Imaging Plate Diffractometer; Rigaku Corporation: Tokyo, Japan, 1998.

(6) Higashi, T. ABSCOR, Empirical Absorption Correction Based on Fourier Series Approximation; Rigaku Corporation: Tokyo, Japan, 1995.

(7) G. M. Sheldrick, G. M. SHELX97, Program for Crystal Structure Determination; University of Göttingen: Göttingen, Germany, 1997.

(8) Becke, A. D. Density-functional exchange-energy approximation with correct asymptotic behavior. Phys. Rev. A: At., Mol., Opt. Phys. 1988, 38, 3098-3100.

(9) Perdew, J. P.; Chevary, J. A.; Vosko, S. H.; Jackson, K. A.; Pederson, M. R.; Singh, D. J.; Fiolhais, C. Atoms, molecules, solids, and surfaces: Applications of the generalized gradient approximation for exchange and correlation. Phys. Rev. B: Condens. Matter Mater. Phys. 1992, 46, 6671-6687.

(10) Frisch, M. J.; Trucks, G. W.; Schlegel, H. B.; Scuseria, G. E.; Robb, M. A.; Cheeseman, J. R.; Scalmani, G.; Barone, V.; Mennucci, B.; Petersson, G. A.; Nakatsuji, H.; Caricato, M.; Li, X.; Hratchian, H. P.; Izmaylov, A. F.; Bloino, J.; Zheng, G.; Sonnenberg, J. L.; Hada, M.; Ehara, M.; Toyota, K.; Fukuda, R.; Hasegawa, J.; Ishida, M.; Nakajima, T.; Honda, Y.; Kitao, O.; Nakai, H.; Vreven, T.; Mont-gomery, J. A. Jr.; Peralta, J. E.; Ogliaro, F.; Bearpark, M.; Heyd, J. J.; Brothers, E.; Kudin, K. N.; Staroverov, V. N.; Keith, T.; Koba-yashi, R.; Normand, J.; Raghavachari, K.; Rendell, A.; Burant, J. C.; Iyengar, S. S.; Tomasi, J.; Cossi, M.; Rega, N.; Millam, J. M.; Klene, M.; Knox, J. E.; Cross, J. B.; Bakken, V.; Adamo, C.; Jaramillo, J.; Gomperts, R.; Stratmann, R. E.; Yazyev, O.; Austin, A. J.; Cammi, R.; Pomelli, C.; Ochterski, J. W.; Martin, R. L.; Morokuma, K.; Zakrzewski, V. G.; Voth, G. A.; Salvador, P.; Dannenberg, 
J. J.; Dapprich, S.; Daniels, A. D.; Farkas, O.; Foresman, J. B.; Ortiz, J. V.; Cioslowski, J.; Fox, D. J. Gaussian 09, Revision D.01; Gaussian, Inc., Wallingford CT, 2013.

(11) Andrae, D.; Haussermann, U.; Dolg, M.; Stoll, H.; Preuss, H. Energy-adjusted ab initio pseudo potentials for the second and third row transition elements. Theor. Chim. Acta 1990, $77,123-141$.

(12) Mennucci, B.; Tomasi, J. Continuum solvation models: A new approach to the problem of solute's charge distribution and cavity boundaries. J. Chem. Phys. 1997, 106, 5151-5158. (13) Grimme, S.; Antony, J.; Ehrlich, S.; Krieg, H. A. A consistent and accurate ab initio parametrization of density functional dispersion correction (DFT-D) for the 94 elements $\mathrm{H}-\mathrm{Pu}$. J. Chem. Phys. 2010, 132, 154104. 